
Digitized by the Internet Archive in 2008 with funding from Microsoft Corporation 



\title{
THE RELIGIOUS HISTORY OF NEW ENGLAND
}

\section{KING'S CHAPEL LECTURES}

\author{
BY \\ John Winthrop Platner George Hodges \\ William W. FenN \\ William E. Huntington \\ George E. Horr \\ Rufus M. Jones \\ John Coleman Adams \\ William L. Worcester
}
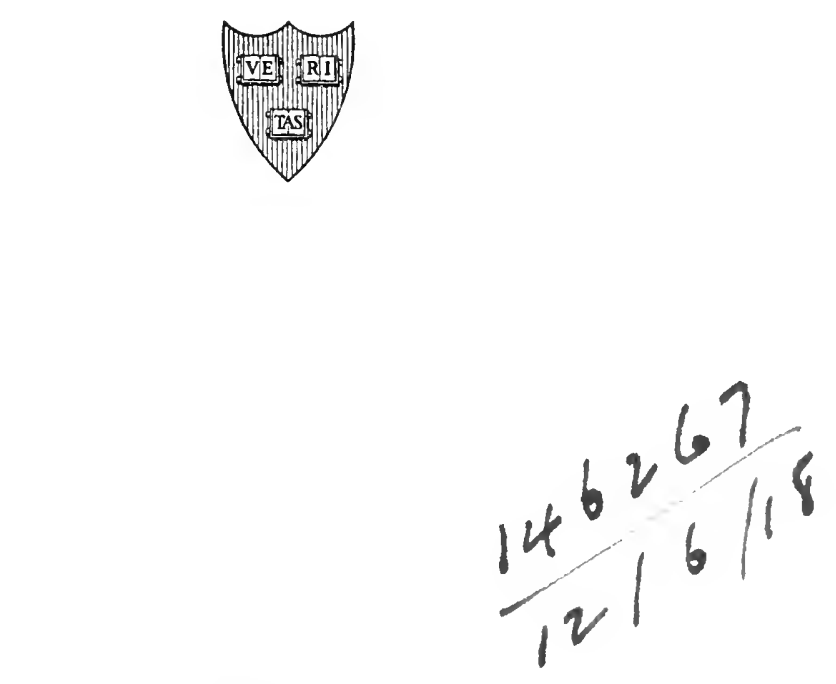

CAMBRIDGE

HARVARD UNIVERSITY PRESS

LONDON: HUMPHREY MILFORD

Oxford University Press

I9I 7 
COPYRIGHT, I9I 7

HARVARD UNIVERSITY PRESS 


\section{PREFACE}

7 HE chapters of this book were prepared and delivered 1 as lectures under the auspices of the Lowell Institute in King's Chapel, Boston, in the winters of $1914^{-15}$ and I9I 5-16. The Committee in charge of the lectures consisted of representatives of the Harvard Divinity School and the affiliated schools, Andover Theological Seminary, and the Episcopal Theological School, Cambridge.

One deficiency the Committee sincerely regret. It appeared impossible to secure either for the lectures or for the book an historical narrative from a member of the Roman Catholic communion. The Committee feel that the book ought not to be issued without at least some word recognizing the contribution which that Church has made to the Religious History of New England. 



\section{CONTENTS}

I. THE CONGREGATIONALISTS $\ldots \ldots$

John Winthrop Platner

Brown Professor of Ecclesiastical History, Andover Theological Seminary

I. The Beginnings of Congregationalism ...... 3

2. The Period of Church Doninance . . . . . . . 22

3. Religion and Theology in the Eighteenth Century. 38

4. Modern Congregationalism . . . . . . . . ${ }_{5} 6$

II. THE REVOLT AGAINST THE STANDING ORDER • 75

WILIIAM W. FENN

Dean and Bussey Professor of Theology, Harvard Divinity School

I. Popular Monements . . . . . . . . . . . . . . . . . 77

2. The Unttarians. . . . . . . . . . . . . . . . . . . . 97

III. THE BAPTISTS . . . . . . . . . . . . . 135

GEORGE E. HoRR

President and Professor of Church History, Newton Theological Institution

IV. THE QUAKERS . . . . . . . . . . . 177

Rufus M. Jones

Professor in Haveriord College

V. THE EPISCOPALIANS . . . . . . . . . . 203

George Hodges

Stone Professor of Homiletics and Pastoral Theology, and Dean,

Episcopal Theological School, Cambridge

I. Before the American Revolution. . . . . . . . 205

2. After the American Revolution . . . . . . . . 227

VI. THE METHODISTS . . . . . . . . . . . . . 249

WilLiam Edwards Huntington

Sometime President of Boston University

I. Personal and Institutional Forces . . . . . . 25I

2. Practical Bearings of New England Methodism . . 273

VII. THE UNIVERSALISTS . . . . . . . . . . 295

John Coleman Adams

Pastor of the Church of the Redeemer, Hartford, Connecticut

VIII. THE SWEDENBORGIANS.

WiLLIAM L. WORCESTER

President and Professor of Scripture Interpretation, Homiletics, and Pastoral Duty, New-Church Theological School, Cambridge 

THE CONGREGATIONALISTS

JOHN WINTHROP PLATNER 



\section{THE CONGREGATIONALISTS}

\section{THE BEGINNINGS OF CONGREGATIONALISM}

$7 \mathrm{HE}$ ecclesiastical forms under which the religious his-

1 tory of New England was begun, and through which that history long continued to unfold itself, were for the most part Congregational. Throughout the colonial period, and well down into the nineteenth century, Congregationalism was the dominant church polity, and the churches of that order remain even today the most important Protestant bodies in New England. In view of the large influence which New England has exercised upon the religious, social, and educational life of the country at large, it must be evident that, altogether apart from the intrinsic interest of the subject, a review of Congregationalism is likely to throw light upon many sides of our national history, and to reveal the working of some of the most significant forces which have ever operated within the territory of the United States.

For Congregationalism is the expression of a certain type of life and character, - self-dependent, God-fearing, industrious, capable, and highly conscientious, - the qualities on which alone enduring social and political institutions can be reared. Bishop Creighton's judgment, the judgment of a trained historian but not an ecclesiastical sympathizer, was hardly an exaggeration of the facts, when he said that Congregationalism "stamped upon the early colonies of America the severe morality and patient industry which have trained a nation." And the late Lord Acton, also a trained historian, but even less than Creighton an ecclesiastical sympathizer, paid his ungrudging tribute to the Puritans 
in general, and Independents in particular, when he said, "The idea that religious liberty is the generating principle of civil, and that civil liberty is the necessary condition of religious, was a discovery reserved for the seventeenth century. . . . That great political idea . . . has been the soul of what is great and good in the progress of the last two hundred years."

It is this chapter of New England history that we are to review together, so far as the narrow limits of our time permit.

Travelling northward one hundred and forty-six miles from London, on the old post-road leading to York and Edinburgh, one comes to the quiet hamlet of Scrooby, ${ }^{1}$ inhabited by scarce two hundred persons, but boasting, as its most interesting possession, an ancient manor house, once belonging to the archbishop of York, but now a shrine of Congregationalism and the goal of pious p lgrimages from New England. Here at the opening of the seventeenth century dwelt William Brewster, master of the post, and here, careful to avoid publicity, assembled crom time to time a little group of earnest men and women, belonging to the advanced party of English puritans, - men and women who were not content to remain within the established church, however its forms and ceremonies might be modified, but felt constrained, in loyalty to the Word of God, to withdraw from all ecclesiastico-political entanglements and, as Bradford puts it, to " join themselves (by a covenant of the Lord) into a church estate, in the fellowship of the Gospel." From this little society of "the Lord's free people" proceeded the impulse which, a few years later, resulted in the first permanent settlement of New England.

1 Scrooby is in Nottinghamshire, near the borders of Lincolnshire and Yorkshire. The nearest railway station is Bawtry. 
The movement for which these men of Scrooby stood was the outcome of many influences, not all ecclesiastical, yet for the most part religious. It represented one branch, - and for many years only a minor branch, - of the great Puritan party, which also included conforming Puritans, Presbyterians, Anabaptists, and perhaps non-separatist Independents. ${ }^{1}$ What differentiated the men of Scrooby from their fellow puritans was their thorough-going ecclesiastical democracy, which might perhaps be called their thoroughgoing protestantism, only protestantism had not yet become fully conscious of its logical goal. The beginnings of the movement are traceable much earlier than the days of William Brewster. The first church organization of the independent type is by some believed to have been the "Privy Church" of Richard Fitz, in London, which goes back at least to the year $157 \mathrm{r}$. Others would regard the still earlier Plumbers' Hall congregation, which met in ${ }^{5} 567$, as the oldest. But so far as direct and permanent influence is concerned, the original centre of the Congregational movement seems to have been in the county of Norfolk, and particularly the town of Norwich, where Robert Browne began his work about the year 1580 , and where local conditions were especially favorable to the development of popular self-governing associations.

Recent investigation has shown that Norfolk was the home of many gilds, semi-religious in character, whose statutes might easily have suggested a form of constitution for churches of the independent order. ${ }^{2}$ Furthermore, nearly twenty years before Browne organized his separatist movement there, at least one of the regular parish churches of

1 Champlin Burrage finds ground for believing that at first not all the independent puritans were separatist in principle. See his Early English Dissenters, I, pp. 28I, 3 то.

2 See an article by J. W. Thompson, in the American Historical Review, April, I913, p. 503 . 
Norwich, St. Andrew's, had already acquired a measure of self-government through the purchase of the right of patronage, whereby it gained the power to call and to dismiss its own ministers. ${ }^{1}$ John Robinson, the honored Pilgrim pastor, thought meanly of this arrangement, which he held to be a poor substitute for the liberty of the New Testament. The passage expressing his opinion is worth quoting:

St. Andrew's is not possessed of that poor liberty it useth by any immediate spiritual right from Christ, as the body from the head, the wife from the husband, - but by a simoniacal purchase from the patron, as the most profane assemblies in the kingdom (in which not a man feareth God) might purchase it, - and so that spiritual liberty, which Christ hath bought with his blood and wherein all Christians ought to stand fast, they buy with a piece of money, committing herein simony as great as Simon did.

Yet the bare existence before their eyes of a church actually possessed of a measure of local control, must have encouraged the separatists to renewed exertions for their more worthy cause. At any rate it was not long after Robert Browne removed from Norwich to Holland, that he published his famous Treatise of Reformation without Tarrying for Any, in which are clearly set forth the principles of separatism and independency. ${ }^{2}$ It remains to this day one of the most valuable summaries of Congregationalism ever written.

Two other champions of early English Congregationalism, Henry Barrowe and John Greenwood, deserve special mention, for they were martyrs to the cause they had so ably served. The one was trained as a barrister, the other as a clergyman, but both became leaders of a non-conforming congregation, known in the history of independency as the

1 Burrage: New Facts concerning John Robinson, p. 2I. Channing calls attention to a similar condition of things prevailing in a church in the town of Boston, in Lincolnshire. See his History of the United States, I, p. 288.

2 Old South Leaflets, No. Ioo. Issued from the Old South Meeting-house, Boston. 
London-Amsterdam church. Daniel Neal, in his History of the Puritans, has preserved a highly interesting account of the formation of this church, and of its simple rites and ceremonies, including the church covenant, the mode of election of officers by the people, their induction into office, and the manner of administering baptism and the Lord's Supper. ${ }^{1}$ The views of Barrowe and Greenwood, showing some divergence from strict Brownism, and lodging more power in the eldership, are conveniently summarized in the "Confession of the London-Amsterdam Church," written in $1596{ }^{2}$

The distinctive features of the churches which these men undertook to establish are found not in creed but in polity. The creed of early Congregationalists was Calvinistic, as was that of all their fellow puritans. "It is well known," writes Increase Mather in I680, "that as to matters of doctrine we agree with other reformed churches; nor was it that, but what concerns worship and discipline, that caused our fathers to come into this wilderness." The marks whereby Congregational churches desired to be known were the independence of the local congregation, its constitution under a covenant, the absence of an episcopate, the conception of the ministry as exercising delegated powers of a purely spiritual nature, reliance upon the sole authority of Scripture, and the separation of church and state. Not all these principles however were the exclusive possession of Congregationalists; other protestants, with equal justice, could lay claim to some of them. And not all of them were consistently applied. Nevertheless, they represent the platform on which our New England forefathers stood, and the manner of church they aimed to rear, - a church in which was the potency of a richer life and a larger liberty than they themselves at first enjoyed.

1 History of the Puritans, I, pp. 543 ff. (2d ed. London, 1732.)

2 Text in W. Walker's Creeds and Platforms of Congregationalism, pp. 4I-74. 
Two features of this simple church organization deserve especial attention, viz., the covenant and the ministry. The former was the organic or fundamental law, by which alone a church could exist. In principle it is closely parallel to the famous Mayflower Compact, whereby the Pilgrim company created their "civil body politic," and began their existence as a state. Governor Bradford's description of the church, formed to be sure before their departure from the old world, sounds like this civil compact transferred to the domain of religion. They " joined themselves (by a covenant of the Lord) into a church estate, in the fellowship of the Gospel, to walk in all his ways, made known, or to be made known unto them, according to their best endeavors, whatsoever it should cost them, the Lord assisting them." 1 By such mutual agreements did the subscribers bind themselves to an orderly community life, in the one case as a body politic, in the other as a body ecclesiastic. And thus the foundations of American democracy, in civil and religious life, were laid together.

Ecclesiastically the subscribers to the covenant gained thereby all the rights and powers which the Lord had bestowed upon his church in the Gospel. They believed that those rights and powers, in fact all the workings of the Christian brotherhood, were precisely defined and described in the New Testament, more particularly in the letters of the Apostle Paul and in the Pastoral Epistles, and to these writings appeal was constantly taken for direction and advice. There was no court of appeal beyond them. The free churches, based upon covenants, were held to be New Testament churches, valid and sufficient against all the hierarchical and ecclesiastical usurpations of history.

1 Bradford adds, with touching simplicity, "And that it cost them something, this ensuing history will declare." History of Plymouth Plantation, p. 3I (ed. W. T. Davis). 
With regard to the second feature of their polity, the ministry, the founders of Congregationalism rejected the traditional view of clerical orders, and maintained the simple theory that the ministry is not an order at all, but merely an office. The "minister" of a church was the man chosen and set apart, from among their own number, to be the pastor and teacher of the rest. He was their " bishop," if they pleased to call him so, - which they usually did not, bishops being unpopular persons among the English separatists. He had no ecclesiastical superior, and according to the early New England practice, he lost his ministerial standing when he ceased, for any reason, to hold a pastoral charge. According to this theory, there was no such thing as a minister, apart from the church he served. ${ }^{1}$ This simplified conception of the ministry, pushed through so courageously by its advocates, was based in the last analysis upon the ancient and highly respectable theory of Jerome, that in the New Testament the terms bishop and presbyter are used interchangeably for the same officer in the churches. (Jerome, Epistles 69 and 146.) It is the theory accepted and maintained by many Protestant churches, and it has found distinguished advocates, like the late Bishop Lightfoot, even within the Episcopal communion. But of course the Congregationalists went a step beyond their brethren in other denominations, in rejecting the entire conception of clerical orders.

The congregations or brotherhoods with which we are immediately concerned, boldly declared their independence, under God, from the established religion of the English realm, and their self-sufficiency as churches, wherever they might find themselves; and thus they re-affirmed the in-

1 This extreme view, represented by the Cambridge Platform, was never accepted by the entire body of Congregationalists, and has long since ceased to be advocated. 
alienable right of the individual in all matters of religion, which had been one of the most momentous implications of the protestant movement. Taking the apostolic churches as their standard, - from which they believed that the organized Christian world had grievously fallen away, - they pronounced severe judgment upon others, and laid themselves open to many a charge of uncharitableness, which their opponents were quick to bring against them. ${ }^{1}$ Yet uncharitableness is very apt to characterize earnest men who, in the face of apparently overwhelming opposition, are engaged whole-heartedly in the most serious affairs of life.

The first little company of separatists came to New England in 1620 . It was a church migration, and may be described geographically as the Gainsborough-ScroobyLeyden-Plymouth church. They left their own mother country as fugitives; they left in turn the place of their temporary sojourn in Holland; and on they came to the American wilderness, - half of their number to die within the first six months, and the other half to lay foundations upon which we are still building.

In comparison with the settlers of the Plymouth plantation, those who came ten years later to Massachusetts Bay were a multitude in number. And their views of the nature of the church were at first not exactly the same. No better description of the spirit and temper which animated the leaders of the great migration can be found than the wellknown words of Francis Higginson to his fellow passengers, when, in the year I629, their ship was off Land's End and headed westward: "We do not go to New England as

${ }_{1}$ "Their chief crime was their uncharitableness, in unchurching the whole Christian world, and breaking off all manner of communion in hearing the Word, in public prayer, and in the administration of the sacraments, not only with the church of England, but with all foreign Reformed churches, which though less pure ought certainly to be owned as churches of Christ." Neal, History of the Puritans, I, p. 379 . 
separatists from the church of England, though we cannot but separate from the corruptions in it, but we go to practice the positive part of church reformation, and propagate the Gospel in America." Similarly, two generations later, the Rev. John Higginson, son of Francis, writing in his old age an "attestation" for Cotton Mather's Magnalia, said of these voluntary exiles, that they "came into a wilderness for that very end, that hence they might be free from human additions and inventions in the worship of God, and practice the positive part of divine institutions, according to the Word of God."

But whatever may have been the precise shades of ecclesiastical opinion held at first in Salem, Boston, and Charlestown, the churches there established, in the early days of the Bay Colony, were Congregational churches, and they all promptly adopted the fundamental principles for which the Pilgrim Fathers at Plymouth stood.

One of the best examples of the early New England Way is found in the proceedings of the Salem colonists in setting up their church. First they formulated this simple covenant: "We covenant with the Lord and one with another, and do bind ourselves in the presence of God, to walk together in all his ways, according as he is pleased to reveal himself unto us in his blessed word of truth." Next they elected Samuel Skelton as their "pastor," and Francis Higginson as their "teacher." Then, to quote from the invaluable contemporary letter preserved for us in Bradford's History:

Mr. Higginson, with three or four of the gravest members of the church, laid their hands on Mr. Skelton, using prayer therewith. This being done, there was imposition of hands on Mr. Higginson also.

The full significance of this simple narrative can be grasped only when one remembers that both these men were already ordained clergymen of the Church of England. 
The mode of procedure at the formation of the Charlestown-Boston church, the following year, was essentially the same, Governor Winthrop and the Rev. John Wilson being two of the four charter members. Other churches were organized throughout the colony, as the tide of immigration strengthened and the number of settlements increased. ${ }^{1}$ In Winthrop's Journal the entries run like this: "A church was gathered at Dedham," or " A church was gathered at the Mount" (Mount Wollaston). The methods pursued in all prove the widespread acceptance of the principle laid down by Thomas Hooker, in his Survey of the Summe of Church Discipline, "The church, as totum essentiale, is and may be before officers." This puts Congregationalism in a nutshell; it is the essence of the whole matter.

A few of the churches of New England were organized before reaching America, such as the church at Plymouth and the first church in Dorchester. A few, like the church in Newtowne, removed bodily from their original place of settlement to another, - in this case, Hartford. With the growth of the larger settlements the first parish was sometimes set off into two, or even more, and town divisions usually followed the same lines. The relation between church and community was much closer in colonial New England than is sometimes supposed.

The connection between church and state was also close, in spite of their theoretical separation, - so close in fact that the government of Massachusetts Bay has often been described as a theocracy. The people of New England were steeped in the conviction that they had been chosen and were led of God, and that every part of their life was under His divine control. No human government could be firmly

1 The exodus, within a decade, of twenty thousand persons from their English homes and their settlement in the Massachusetts Bay colony, constitute one of the most significant instances of race-migration which history can show. 
established, unless based upon the divine. The principles of this divine government were clearly set forth in Scripture, and to the Scriptures one must look if one would learn the will of God. The way of the churches was plainly described there; and there too was legislation for the community. Accordingly the colonists made a double appeal to the Bible, as to a God-appointed constitution for the church and for the state, - with the natural result that their type of government during all the early years was decidedly theocratic.

Furthermore, large numbers of ministers came to New England, - nearly one hundred of them in the first twenty years, - and nearly all accepted parish charges. These ministers were for the most part graduates of the University of Cambridge, the nursery of puritanism, and they represented a much higher professional type than the clergy who went to Virginia and Maryland, where their influence was comparatively slight. The high intellectual and spiritual level on which the New England ministers stood, and the popular respect which they immediately gained, greatly strengthened the theocratic tendency. They were constantly consulted by the magistrates and governors, not only on matters pertaining to religion, but also on questions of colonial policy and legislation. Their advice was freely given, sometimes even before it had been asked; yet it was never unwelcome. In I635, the Rev. John Cotton drew up, for the use of the General Court, a law-code based upon " Moses, his judicials," and this, or something like it, formed a large part of the groundwork of the legislation in the Bay colony for many years. Citations of Biblical authority were deemed conclusive in the court room, and capital punishment long continued to be inflicted for a variety of offences specified in the book of Leviticus.

This mixture of law and religion of course gave rise to difficulties, and aroused criticism. It was the persistent 
exercise of jurisdiction over offences " against the first table of the law" (i. e., against the first four commandments of the decalogue) that provoked the open hostility of Roger Williams against the authorities, and caused him to protest that the things of God and the things of Caesar should not thus be confounded, - a protest which brought him into trouble. Yet for more than a generation the theocracy maintained its hold upon the colony, and when at last it fell, it was only after bitter controversy, and amid the lamentations of the conservatives, who sincerely believed that the days of New England's greatness were ended.

It is a curious fact that democracy, the very thing towards which the Congregational movement tended, should have been so much distrusted by the early New England leaders, as it still is today by some of their successors. In a letter to Thomas Hooker, Winthrop once "expostulated about the unwarrantableness and unsafeness of referring matter of counsel or judicature to the body of the people, quia the best part is always the least, and of that best part the wiser part is always the lesser." John Cotton frankly expressed his disbelief that God ever ordained the democratic form of government, either for church or for commonwealth, adding this poser, - "If the people be governors, who shall be governed?" It was not the first time that a great cause has been promoted by those who profoundly disbelieved in it.

To maintain the purity and propriety of the colony, and to perpetuate the chosen governmental system, the magistrates of Massachusetts Bay watchfully supervised all persons who came within its borders. It was entirely natural and praiseworthy that they should exclude such obviously undesirable citizens as Thomas Morton, of Merrymount fame, and Sir Christopher Gardiner, along with the " comely young woman" with whom he set up his irregular residence at Neponset. Less justifiable, however, seems the exclusion 
of the "Antinomians," of whom Anne Hutchinson was chief, and of the Quakers, and all persons leaning towards episcopacy. The attitude of the New England standing order towards dissenters was not unlike that in the mother country, only with the rôles reversed. Our forefathers were, no doubt, intolerant; they made no claim to be anything else. They closed their doors against dissent. They limited the franchise to members of recognized churches. They levied public taxes for the support of religion in the towns. But they did these things because only through such means could they assure stability for their institutions, and prevent political and ecclesiastical disintegration. All their precautionary measures were but the outward expression of a fundamental religious loyalty. ${ }^{1}$ They would not tolerate a godless government or a merely secular society; everything should be permeated by the divine life, and based upon the divine authority to which they had solemnly pledged themselves from the first moment of their high adventure. As a result, they established a commonwealth so homogeneous in character, that it retained many of its distinctive features for nearly two hundred years. ${ }^{2}$

The so-called Antinomian Controversy, which broke out only a few years after the settlement of Boston, was the first serious internal disturbance that the colonists were called upon to face. A variety of causes, - political, ecclesiastical, and social, - combined to render it acute. Mrs. Hutchinson, a gifted but indiscreet woman, was the centre of the controversy, and the chief sufferer from it, but the governor and the ministers were also involved. Mrs. Hutchinson's

1 The whole matter was thus briefly and accurately summed up by the late Professor Diman: "The support of religion, not the endowment of any specific church establishment, was what they had in mind."

2 Professor Barrett Wendell, in his Literary History of America, calls attention to the effects of this social homogeneity and isolation upon the remarkable development of American literature in the nineteenth century. 
dismissal from the Boston church, as well as from the colony, after an unfair trial, reflected little honor upon the elders and magistrates, but showed with the utmost distinctness that no irregularities of belief or of conduct would be tolerated in Massachusetts. ${ }^{1}$

Some of the Congregationalists of New England tended to favor a presbyterial system of church government, and it was an open question for a time whether a few of the churches might not adopt that polity. In Newbury, for instance, such a tendency was clearly discernible, and a synod was convened at Cambridge to consider the whole matter. ${ }^{2}$ After friendly consultation, the council, to quote Winthrop's words, "concluded against some parts of the presbyterian way." As a matter of fact the Massachusetts churches never proceeded very far in the direction of Presbyterianism, but in Connecticut and certain districts of Long Island there was much less hesitation, as we shall see.

More conspicuous and permanent was the Baptist movement from the days of Roger Williams onward. After an unsuccessful effort to establish himself within the jurisdiction of Massachusetts, Williams journeyed southward and laid the foundations of the Providence Plantations, where later he developed his anti-paedobaptist views and put them into practice. The Baptist churches, being Congregational in polity, should not be regarded as a strange or novel denomination in New England, however unwelcome they may have been made there. 'The points of difference relate to church membership and to the sacrament of baptism, - not to the mode of organizing the churches. But the points of difference have proved to be stronger, and have been more tenaciously held, than the points of agreement. Particularly

1 An interesting account of Antinomianism may be read in Charles Francis Adams's Three Episodes of Massachusetts History.

2 This assembly is not to be confounded with the well-known Cambridge Synod, which met four years later. 
in the early days there was hostile feeling between the two denominations, and every effort was put forth by the standing order to suppress the Baptist movement at the very outset.

The most significant event in early Baptist history, next to the work of Roger Williams, was the conversion of President Dunster, of Harvard College, about the year I65o. Dunster's withdrawal from Congregational fellowship, and his acceptance of Baptist principles, startled the adherents of the standing order, and greatly encouraged the few struggling representatives of the Baptist cause. To allay public alarm, and refute the threatening "errors," Jonathan Mitchell, pastor of the church in Cambridge, "preached more than half a score of ungainsayable sermons " in defense of the "comfortable truth" of infant baptism. But not even these ten discourses, or the open opposition of the authorities, sufficed to prevent the gathering of the first Baptist church in Boston a few years later.

The unpleasant impression produced upon the modern mind by the firm resistance against all manner of " innovations," Baptist or any other, is partially offset by a feeling of satisfaction over the whole-hearted devotion to the welfare of the surrounding Indian tribes, displayed by some of the colonists. To convert the Indians to Christianity had indeed been one of the avowed aims of the settlers of New England, but the engrossing activities and the hardships of pioneer life had left them little room for missionary labor. Yet at least one minister, John Eliot of Roxbury, carried missionary responsibility on his heart, devoting long and patient labor to the acquisition of the Indian language, until he qualified himself to use it in preaching to the red men of Nonantum. ${ }^{1}$ He also translated the Bible for their daily use,

1 An interesting almanac, prepared by Samuel Danforth for the year r649, contains a chronological table of events, in which we find this entry: 1646, "Mr. Eliot began to preach to ye Indians in their own language."

Eliot's Indian Bible was printed in Cambridge, on the press of Stephen Daye. 
and his efforts were rewarded by the gathering of an Indian church at Natick. Similar efforts were put forth by the Mahews at Martha's Vineyard, and thence in time came an Indian lad to Harvard College, to receive his degree of Bachelor of Arts in 1665 .

Notwithstanding Eliot's disinterested labors in their behalf, Christian work among the Indians lagged. He seems to have had no successors who were equal to the task, and the indefatigable diarist, Judge Sewall, is presently found piously lamenting the futility of all efforts for the conversion of the natives, and even venturing to imply a criticism of the divine inactivity in the matter. He writes to Stephen Dummer that he is persuaded it would be " a most acceptable sacrifice to God importunately to beseech him to put his hand to that work, and not in a great measure, as it were, to stand and look on." But neither prayers nor efforts seemed to avail, and King Philip's War finally put an end to active missionary propaganda in Massachusetts. Such measures as were taken thereafter for the conversion of the Indians were due chiefly to the Society for the Propagation of the Gospel in New England, which had been organized by the Long Parliament in consequence of the interest aroused in England by what Eliot had done. ${ }^{1}$

What may be regarded as the opening chapter of New England Congregationalism ends with the historic Cambridge Synod, of which the most important sessions were held in the year I648. This was the first and only general synod of the free churches of New England during the entire colonial period, and it had no successor until the Albany Convention of $185^{2}$. Some fifty churches, from all four of the federated colonies, were represented by their elders and

The few surviving copies, - rarissima, among collectors, - are probably the least read books in the world at the present time.

1 This society must not be confounded with the later (Anglican) Society for the Propagation of the Gospel in Foseign Parts, which dates from r 701. 
messengers, and the Synod felt itself qualified to consider any problem of church government or discipline, although it had no direct legislative authority. Its most important conclusions are embodied in the Cambridge Platform, drawn up for the most part by Richard Mather, which sets forth what we may regard as the general ecclesiastical practice of the period.

The substance of the Platform may be inferred from its definition of the church:

A Congregational Church is, by the institution of Christ, a part of the militant visible church, consisting of a company of saints by calling, united into one body, by a holy covenant, for the public worship of God and the mutual edification one of another, in the fellowship of the Lord Jesus (Platform, II, 6).

This definition states with the utmost clearness the fundamental tenet of Congregationalism, namely, the autonomy of the individual church. The Platform proceeds to assert that the church is " before, and independent of " its officers; that there is no visible universal church, that is, none greater than a congregation "which may ordinarily meet in one place"; but that the churches have a sort of collective life by means of the mutual exercise of "fellowship." The name, "Independent," instead of Congregational, is not approved. In England, however, that denominational name became in time very popular.

The question of a creed came before the Synod, but it was decided that no new formula was needed. The Westminster Assembly of Divines had just completed its Confession of Faith, and this, being a good Calvinistic symbol, was adopted, for substance of doctrine, by the Cambridge Synod. There was, however, some objection to the article on "Vocation," with regard to which a few of the New England fathers appear to have cherished doubts. Thus, from the first, the Westminster Confession took its place in the religious history 
of America; it was re-adopted, with a few slight modifications, by the Boston Synod of I680, and remained for generations the accepted doctrinal standard of New England Congregationalism.

The action of the Cambridge Synod met with practically unanimous approval throughout New England, after the scruples of a few of the most strongly individualistic churches against any and every effort after collective action had been overcome. There was no attempt to put the new standards into force until they had been approved by the several churches, which alone, it was insisted, possessed the power to legislate, each for itself. After approval had thus been secured, the General Court of Massachusetts officially endorsed the Platform, which in effect conferred upon the churches which it represented a quasi-establishment. Congregationalism was indeed, from that time on, the standing order of New England.

We must not leave the Cambridge Synod without noticing an incident at the opening of its most important session, which illustrates the vivid consciousness of the divine presence, always cherished among the colonists. During the sermon a snake wriggled into a seat near the pulpit, and, after causing some natural commotion, was killed by one of the elders. The incident was not allowed to pass without pious interpretation. "Without doubt," writes Winthrop in his Journal, "the Lord discovered somewhat of his mind in it. The serpent is the devil; the synod, the representatives of the churches of New England. The devil had formerly and lately attempted their disturbance and dissolution; but their faith in the seed of the woman overcame him and crushed his head" (Journal, II, pp. 347 f.).

While the churches were thus consolidating their government and discipline, the western drift of population had already begun, carrying organized religion with it. Among 
the first migrations was that of Thomas Hooker and his flock, from Newtowne (Cambridge) to what was destined to become the important city of Hartford. Others went from Watertown, Dorchester, and Roxbury, to establish settlements at Wethersfield, Windsor, and Springfield. The town and church of New Haven were founded but little later, under the leadership of John Davenport and Theophilus Eaton. All these churches had their origin prior to the year I640, and all played an important part in the development of the Connecticut valley and southern New England. In polity, however, some of them diverged from the Massachusetts pattern, and we shall presently have an opportunity to see how, in the Saybrook Platform, the Connecticut churches leaned towards the Presbyterianism of their neighbors on the west. 


\section{THE PERIOD OF CHURCH DOMINANCE}

WITHIN twenty years from the first settlement of Boston, ecclesiastical and civil society had become securely established, and were in good working order throughout the Puritan communities which together made up New England. ${ }^{1}$ The life of the inhabitants was simple, in comparison with ours, yet it was dignified and on formal occasions even ceremonious. Apart from general care for the public safety, which the hazards of frontier life rendered imperative, the chief occupations were manual labor of various kinds, reading, and the exercises of religion. "It is never to be forgotten," wrote John Higginson some years later, "that our New England is originally a plantation of religion, and not a plantation of trade. If any man among us makes religion as twelve, and the world as thirteen, let such a man know that he hath neither the spirit of a true New England man, nor yet of a sincere Christian." This plan of life was indeed that of the leading spirits, among the laity as well as among the clergy, throughout the period before us. There were no public amusements and no newspapers. Travel, being attended with some risk, was attempted only within narrow limits, unless forced by necessity; it was never a means of recreation. The stated services of the Sabbath, together with the Thursday lecture, furnished decorous opportunity of meeting friends and neighbors, and supplied to the people their chief intellectual as well as spiritual stimulus.

The meeting-houses were plain to severity, but dignified, and sometimes their lines were not without architectural beauty. Greater emphasis was laid upon social distinctions than we should have expected to find, and the seating

1 The region of Rhode Island ought perhaps to be excepted, not because it was not Puritan, but because its institutions developed along somewhat different lines. See I. B. Richman, Rhode Island; its Making and its Meaning. 2d ed. I908. 
arrangements of the churches were carefully worked out with this in view. To each seat was assigned a social valuation. In time this was reduced to a system. Thus in Deerfield, in I70I, it was officially determined that " the fore seat in the front gallery shall be equal in dignity with the second seat in the body of the meeting-house." Inferior seats were set apart for domestic servants and for slaves. In the Presbyterian church at Newburyport, built about the middle of the eighteenth century, one may still see the pews in one corner of the gallery, where negro slaves were seated. On the other hand, the elders and deacons had seats of especial honor near the pulpit, and usually facing the congregation. ${ }^{1}$

On the Lord's Day there were two preaching services, the first in the morning, earlier than is now customary, and the second early in the afternoon. Scripture reading (with comments), prayer, psalmody, and a sermon, made up the order of exercises. Nothing in the slightest degree suggestive of liturgical worship, - not even "dumb reading," - was for a moment tolerated. ${ }^{2}$ The Bible version in common use among the first settlers was that of Geneva, not the King James Version, which was slow in supplanting it. Sternhold and Hopkins's metrical version of the Psalms was available for the singing, but before long New England had a version of its own,-the Bay Psalm Book, which was the first book printed in the colony. Fuller's quaint criticism of the

1 See D. W. Howe, The Puritan Republic of Massachusetts Bay, chap. 8, where much interesting information about ecclesiastical customs, etc., is presented.

The importance attached to social position in early New England finds further proof in a practice of the two colleges, Harvard and Yale, whereby the names of their students were arranged, not alphabetically, but according to their social standing. See the Quinquennial Catalogues. The alphabetical arrangement begins at Yale with the class of $\mathbf{1} 769$, and at Harvard with the class of $\mathbf{1 7 7 3}$. The older custom came to an end just in time to permit graduates of the two colleges to join in the social creed of the Declaration of Independence, that " all men are created equal."

2 "Dumb reading" was a term of reproach, applied to the custom of reading from the Bible without comments, as in the church of England. 
former would apply equally well to the latter; the authors " had drunk more of Jordan than of Helicon." In fact they felt free from any necessity to drink of Helicon at all, and frankly admitted it. "The Lord's Altar," said they, " needs not our pollishings; Ex. 20."

The Psalms were "lined off," and one of the better singers in the congregation was appointed to " set the tune." Judge Sewall was for many years leader of the singing at the Old South Church, and his Diary records a melancholy experience, when by reason of age he had ceased to be acceptable to the young people, in the exercise of this important function. "In the morning," he writes, "I set York tune; and in the second going over the gallery carried it irresistibly to St. David's, which discouraged me very much." There was no help from any musical instrument, for organs were held in contempt by the Puritans. "One groan in the spirit," said Sir Edward Deering in the Long Parliament, " is worth the diapason of all the church music in the world." And so thought the New England fathers.

Certain ceremonies which, to modern thinking, are properly regarded as religious, were by the early colonists deemed secular, for reasons which might be logical, but seem to us inadequate. Such were marriages and funerals. These were held to be no affair of the church, since all may marry, if they will, and all must die. The ceremonies of the church were solely for the elect. The precedent was set at Plymouth at the very beginning of the colony's existence. According to Bradford's History," "May I2, [I62I,] was the first marriage in this place, which, according to the laudable custom of the Low Countries, . . . was thought most requisite to be performed by the magistrate, as being a civil thing, . . . and nowhere found in the Gospel to be laid on the ministers as a part of their office." This precedent was long

1 Bradford's History of the Plymouth Plantation, p. Ir6. 
observed by the Congregational churches of New England. Palfrey could find no instance of prayer at a funeral earlier than 1685 , nor any instance of a marriage by a minister before 1686 .

The religious observance of even the most important festivals of the ecclesiastical year was studiously avoided, as savoring of prelacy if not of popery. Even so late as the eve of the American Revolution, Ezra Stiles thought it worthy of record that a young Baptist minister in Newport had ventured to preach a Christmas sermon. "So this looks more like keeping Christmas than anything that ever before appeared among the Baptists or Congregationalists in New England" (Stiles, Diary, I, pp. 324f.). The well-known incident of certain new-comers in Plymouth, who had conscientious scruples against working on Christmas Day, and accordingly were excused from their appointed tasks, - but who afterwards were found to entertain no scruples whatever with regard to play, and accordingly were punished, - is related by Governor Bradford with sardonic humor.

The exercise of church discipline was usually entrusted to the elders, although usage was not uniform in this regard. The early church records prove that disciplinary cases were not infrequent. Judgments were pronounced in accordance with the Scriptures, especially the Mosaic laws. But some offences which, with us, would naturally be thought to fall under the jurisdiction of the church, were then tried by civil magistrates, and vice versa. The two kinds of jurisdiction were closely and intimately related, as they had been in Geneva, and, under a very different ecclesiastical system, in Roman Catholic Europe during the Middle Ages.

On rare occasions church discipline seems almost to have broken down, owing to the operation of forces so purely human as to provoke a smile from the modern reader. This was the case in the early days in Boston, when magistrates 
and elders attempted to coöperate in enforcing sumptuary regulations, but without success:

The court, taking into consideration the great disorder general throughout the country in costliness of apparel, and following new fashions, sent for the elders of the churches, and conferred with them about it, and laid it upon them, as belonging to them, to redress it, ... . which they promised to do. But little was done about it; for divers of the elders' wives, etc., were in some measure partners in this general disorder. ${ }^{1}$

There were forces at work in New England to which even the leaders of the theocracy were obliged to submit. But instances of defeat were not common, and on the whole, judicial process in the state, and disciplinary process in the church, went on uninterrupted to their appointed ends.

The latter half of the seventeenth century witnessed many political and religious changes in Massachusetts, of which the former were more obvious, but the latter were not less real. King Philip's War, which was both disastrous and costly, wrought disturbing effects upon morals and religion. The mission to America of Edward Randolph, described as a royal messenger, but in fact a spy, embittered the colonists against the English government, and their bitterness was intensified by the revocation of the colonial charter and the appointment of a royal governor in the person of Joseph Dudley. He was presently succeeded by Sir Edmund Andros, who landed in Boston shortly before Christmas, I686, and brought with him a pomp and circumstance to which puritan New England was unaccustomed and which it cordially disliked. He brought also the cross of St. George, which was religiously obnoxious, and a body-guard of red-coats, who distributed contempt and profanity among the people. By no means least, in the catalogue of his offences, was the introduction of episcopacy, which flaunted its hated cere-

1 Winthrcp's Journal, I, p. 279. 
monies in the very face of the ministers and elders, now helpless to prevent them. An Anglican clergyman, Robert Ratcliffe, landed in Boston in I686, and with him begins the celebration of the sacraments and the conduct of public worship according to the Book of Common Prayer. "Baal's priest," some of the puritan fathers contemptuously dubbed him. A church was organized the same year, and as none of the existing congregations would lend its place of worship for such an unscriptural purpose, the Episcopalians were forced to hold their first services in a small room in the town house. The Old South meeting-house was finally compelled to open its doors to the royal governor, - they were in fact forced open on a Good Friday, - and thus the Episcopal enterprise went lamely on until the completion of the first King's Chapel.

News of the revolution which overthrew the Stuarts and brought William of Orange to the throne of England was eagerly and joyfully received in Massachusetts Bay, and was followed by a local uprising in Boston which resulted in the arrest and imprisonment of Andros and Randolph, and the downfall of their government. Meanwhile Increase Mather, the leading figure among the ministers of New England, by patient and skillful diplomacy abroad, secured a new charter, under which Plymouth and the Bay Colony were united, and self-government once more became a possibility, although governor and council were still appointed by the crown. From this time onwards, until the Revolutionary War, all the American colonies developed on the same general lines, politically speaking. "Everywhere the Assembly claimed for itself the powers and privileges of the House of Commons, and everywhere it denied that the Council bore any resemblance to the House of Lords." 1 Thus the colonists continued quietly to train themselves

\footnotetext{
1 Channing, History of the United States, II, p. 248.
} 
in the art of self-government, and to prepare for independent national life, as part of the United States of America.

It was impossible for Increase Mather, notwithstanding all his skill and all his personal interest, to secure under a new charter such exclusive privileges for the churches of the standing order as they had enjoyed under the old. Here and there a church of another denomination had already invaded territory formerly occupied by the Congregationalists, ${ }^{1}$ and even among the Congregationalists themselves voices were heard, criticizing the conservatism typified by the Mathers. The signs of change were small, but unmistakable, and there was anxiety among the upholders of the old theocracy.

Most significant of the emergence of a changing spirit was the formation in Boston in 1699 of a new church, without consultation with the neighboring churches and without permission from the magistrates, - the Brattle Street Church, - whose early history is intimately connected with that of Harvard College. Among the fourteen original members were two college tutors and the college treasurer. The first minister was Benjamin Colman, a Harvard graduate, who, instead of seeking ordination in the regular way at the hands of the elders of New England, was ordained to the ministry by the Presbytery of London, and assumed his pastorate in Boston without further ceremony. "A wandering Levite, who has no flock," was Increase Mather's picturesque and Biblical phrase, descriptive of Colman's ecclesiastical irregularity.

The prospective members of the new church issued a manifesto in which they declared their allegiance to the Westminster Confession of Faith, but at the same time advocated

1 In 1679 a Baptist meeting-house was erected in Boston, but only by the ruse of concealing its ecclesiastical purpose from public knowledge. The first Episcopal Church was built in 1689 . 
certain novelties in worship and discipline. They would have from their pulpit "dumb reading" of the Scriptures, instead of reading with comments by the minister; they would abandon the requirement of public " relations" from persons joining the church; they would permit others than church members to have a voice in the selection of a pastor; and they would admit to baptism the children of parents who had not entered into covenant fellowship with them.

This programme was viewed by the older churches of Boston as lawless and highly reprehensible, but the timespirit can be seen at work in all its innovations. The abandonment of "relations" marks the recognition of the impropriety of exposing the soul's innermost experiences to the public gaze. Religious reticence was destined greatly to increase with the lapse of years, and indeed to proceed so far that at last it would be hardly an exaggeration to say, as did President Quincy, of Harvard College, that religion had "withdrawn from the domestic altar to the retirement of the mind."

The admission to baptism of children whose parents were not church members introduces us to the consideration of what was called the "Half-way Covenant," - an institution which played an important part in the history of Massachusetts, since it had political as well as ecclesiastical implications. It was customary in the churches to require evidence of regeneration, as a condition of admission to membership, and this evidence was expected to be clear and unmistakable. Only persons in full covenant membership were entitled to present their children for baptism. But what was to be said of baptized persons who reached maturity without consciously experiencing regeneration? Were they, or were they not, entitled to any of the privileges of the church? There was long and earnest discussion of these questions. They were brought before local synods, and even came into 
the legislature, in connection with the question of the franchise. Some churches refused to consider any baptized person as an outsider, yet it was not easy to determine precisely what his ecclesiastical privileges should be.

In the end a qualified sanction was given to the practice of admitting all baptized persons to Half-way Covenant membership, - "associate membership," it would now be called, - whereby, upon condition of "owning the covenant" and promising to conform to the discipline of the church, they received certain limited privileges, such as the right to present their own children for baptism. Usually they were not admitted to the Lord's table, although a few instances of that occurred, nor did they as a rule obtain the franchise. Nevertheless, the formal recognition of a class of church members, not consciously regenerate and not under full covenant obligations, inevitably tended to relax the old strictness, and to weaken the hold of the churches upon the popular imagination. New England puritanism was unquestionably somewhat secularized in the process, but a counter change was wrought in the eighteenth century by the Great Awakening, which did much to recover the lost ground.

The foundation of the Brattle Street Church, with all the attendant circumstances, unquestionably loosened the hold of the conservatives upon Harvard College and upon the church life of Boston. But they were reluctant to be set aside, and made strenuous efforts to maintain their position. Early in I700, Increase Mather published his Order of the Gospel, a controversial work in which he rebukes the recent "innovations," and, along with a constructive statement of the standing order and discipline, expresses the hope that the churches will pray for the college, "that God will ever bless that society with faithful tutors that will . . . not hanker after new and loose ways." The year after the publication 
of this querulous book, Mather retired from the presidency of Harvard, and thereafter confined himself to his pastoral labors in the Second Church of Boston, where his son, Cotton Mather, was associated with him, and eventually became his successor. So high, however, was the esteem in which he was held, - for he was without question the foremost minister in America, - that his advice and counsel were constantly sought on all sorts of matters pertaining to education and religion, and for many years he exercised an influence not unlike that of a bishop in the Episcopal communion. Only among the progressives were the Mathers less highly regarded, since they seemed to represent a superseded order. Their last days were tinged with the melancholy that enters into the souls of men who see the world slipping by them, and are powerless to hold it back.

Among the factors which contributed to discredit the Mathers, - although its influence was not immediate or decisive, - was the part they played in the persecution of alleged witches. In this sad and tragic episode in New England history one may see how much of fear and how much of superstition still lingered among the most intelligent of men. America, however, was not unique in cherishing the delusion of a belief in witchcraft. Indeed the persecutions in New England were mild in comparison with what took place in parts of Europe. For the belief was general, and to many persons it seemed inseparable from belief in the Bible and in God. ${ }^{1}$ The prevalent ideas on the subject were clearly set forth in Cotton Mather's Discourse on Witchcraft, preached in Boston in I689. In the course of this elaborate discussion of the subject, Mather finds two proofs that witchcraft exists; the testimony of Scripture, and the evidence of

1 Sir Thomas Browne, the famous physician and philosopher, could say: "I have ever believed, and do now know, that there are witches. They that doubt of these do not only deny them, but spirits: and are obliquely, and upon consequence, a sort, not of infidels, but atheists" (Religio Medici, I, p. 30). 
experience. For the former he appeals to the narrative of the Witch of Endor (I Sam. xx), and for the latter, he cites examples from recent history. New England was regarded as an especially favorable scene for diabolical operations, since it was a wilderness, - in which by preference devils were believed to dwell, - and their resentment at being dispossessed, especially by the chosen people of God, could easily be understood. Hence the violence of their hostility, as evidenced by the outbreak of cases of "possession" in Salem and in Andover.

There was an official investigation, by a commission appointed by the governor, and in the year 1692, when the epidemic reached its climax, there were twenty executions, mostly by hanging. ${ }^{1} \quad$ But the popular excitement died out almost as quickly as it had arisen, and some of those who had been most active in the persecutions afterwards repented, and publicly confessed their grievous error. But neither Increase Mather nor his son Cotton betrayed any consciousness of having been mistaken, much less did they confess it. On the contrary, their confidence in the local triumph of diabolism seems to have remained unshaken. As in the beginning the land was the abode of evil demons, so in the end the devil would claim his own. In a sermon preached at Harvard College, late in I696, President Mather cast a horoscope of the future, and cast it direfully: "It is the judgment of very learned men," said he, "that, in the glorious times promised to the church on earth, America will be Hell."

The foundation of Yale College at Saybrook, in I 7or, was welcomed by the Boston conservatives, as a ray of hope in an age of increasing darkness. Its founders were heartily

1 There had been about a dozen executions before this time. For the documents, see the important collection of Narratives of the Witchcraft Cases, edited by G. L. Burr, New York, I9I4. 
in sympathy with the Boston group, and diligently sought their counsel, which was readily given. Judge Sewall outlined in advance a programme of study for the new college, which should fortify the students against every encroachment of error.

Let them read the Confession of Faith set forth by the Assembly of Divines at Westminster, which is turned into good Latin. . . . Let the President be enjoined to read and expound the Scriptures in the Hall morning and evening de die in diem. Let the scholars be obliged to obey the President. ... L Let the entire course of exercises be severely and strictly exacted without dispensation to any (Letter to James Pierpont, Sept. I7, I70I).

The students of this institution at least were to walk in the ways of the fathers, and not to hanker after anything new or loose!

Cotton Mather was instrumental in securing for the new college a substantial benefit, in the fortune of Elihu Yale, and thus indirectly deserves the credit of having provided the institution with a name. But hardly had Yale been established in its permanent home, New Haven, when startling news went broadcast, bringing consternation to the Congregational world, and above all to the conservative party. The Rector, Timothy Cutler, and the tutor, had gone over to episcopacy! This was, if possible, a more serious schism than that of Harvard's president to the Baptists seventy years before. The sensation in ecclesiastical circles can be imagined. President Woolsey, speaking at the one hundred and fiftieth anniversary of Yale, said: "I suppose that greater alarm would scarcely be awakened now if the theological faculty of the college were to declare for the Church of Rome, avow their belief in transubstantiation, and pray to the Virgin Mary."

As if to add insult to injury, Cutler came to Boston, where, the very year of Increase Mather's death, he assumed 
charge of Christ Church, the second church of the Episcopal order to be established in the town. Presently, in company with the rector of King's Chapel, he applied to the General Court for instatement as an Overseer of Harvard College! This application was of course refused, but it is not without interest to find that now Benjamin Colman is the champion of the established order, for it is he who replied to the argument of the petitioners, and showed that only Congregational " teaching elders" were eligible for the office of Overseer of the college. Later on, during the great evangelistic movement, we find Mr. Cutler issuing violent and abusive attacks upon the work of Whitefield and his associates. And it must be said that much of his energy appears to have been absorbed in protests of various kinds. He scattered them freely along the pathway of his life, and through them perhaps some good was ultimately wrought. Even in very ancient times the prophetic spirit was able to discern that, amongst more easily recognizable blessings, the Lord also sent hornets (Deut. vii. 20).

As in the Bay Colony, so too in Connecticut, the college and the churches were from the beginning very intimately related, and the one cannot properly be studied without the other. At Yale this connection was perhaps more faithfully preserved than at Harvard, for until recent times every member of the college corporation, as well as every president, was an ordained minister. How close this association was at the beginning, appears in 1708 , when the churches were convened in synod, by order of the General Court, and met in connection with the college commencement. The Saybrook Synod was to the Congregationalism of that section of New England what the Cambridge Synod was to Massachusetts. It formulated and defined the polity of the churches, setting the standard to which all should conform. But the Saybrook Platform exhibits marked differences 
from the Cambridge Platform, and to understand them we must glance backward at the course of events in England during the period immediately following the Act of Toleration.

At that time English Presbyterians and Congregationalists found themselves drawing together in a conscious fellowship, and it so happened that just then Increase Mather appeared among them, on his mission in behalf of a new charter for the Massachusetts Colony. Mather lent all his considerable influence to the promotion of the consolidation. The two groups of churches actually did adopt a compact, known as the "Heads of Agreement," under which it was hoped that complete union might be attained. But like all such irenic programmes this was a compromise, and, on the part of the Presbyterians, almost a complete surrender. It was accurately described, by an English Congregationalist who recognized its weakness, as " no more than a verbal composition, or a number of articles industriously and designedly framed with great ambiguity, that persons retaining their different sentiments about the same things, might yet seem to unite." 1 One is not surprised, therefore, to learn that this nominal agreement lasted only a short time in England, passing swiftly into neglect. But in America it had an important influence, for the alliance between Presbyterianism and Congregationalism, which it depicted, commended itself to the ministers of Connecticut, and its substance was incorporated into the Saybrook Platform. Here then is the source of that presbyterial tendency which has so often been noticed among the churches of southwestern New England.

Meanwhile several of the ministers in Massachusetts, desiring to stem the tide of change and to restore the old strictness and sobriety, met together and prepared a plan

1 Quoted by Walker, Creeds and Platforms, p. 446. 
for the systematic organization of associations of ministers, consociations of churches, and standing councils, which, when examined, was found also to approximate towards the presbyterial way. It was formally embodied in the "Proposals of 1705 ," issued by a committee representing at least five of the existing ministerial associations of Massachusetts. ${ }^{1}$ The Mathers urged the adoption of these Proposals, which led Ezra Stiles to charge them with having endeavored " to presbyterianize the New England churches, by resolving all under ecclesiastical judicatories" (Diary, I, p. 37), but the plan failed to meet with approval and was dropped. In Connecticut, however, the Proposals received a more cordial welcome, and the Saybrook Platform adopted with but little change their principles of church government and discipline.

Against all these presbyterianizing measures there arose a champion of ecclesiastical democracy, in the person of the Rev. John Wise, of Ipswich, who defended the liberties of the churches with all the weapons of learning, logic, and irony. ${ }^{2}$ So vigorous and well presented were his arguments, that his books were re-issued, as political tracts, at the time of the Revolution; for the same course of reasoning which would convince a man of the validity of a democratic church, might also convince him of the validity of a democratic state.

The General Court of Connecticut was well disposed towards the churches, and so was Governor Saltonstall, who was himself a minister; they approved the conclusions of the Saybrook Synod, and proceeded to enact the Platform into law. Toleration of dissent from the standing order was

1 There had been purely voluntary associations of ministers in New England from a very early day, but they assumed no ecclesiastical jurisdiction. They seem to have met less frequently after the Cambridge Synod, but were revived towards the end of the century.

${ }^{2}$ See his books entitled, The Churches' Quarrel Espoused, I 7 10, and Vindication of the Government of the New England Churches, 1717 . 
however secured. The Saybrook Platform remained in force until 1784 , when, by a revision of the statutes, it was omitted, and thereby practically repealed. ${ }^{1}$

It is clearly evident that Connecticut Congregationalism was different in type from that of Massachusetts, and the churches were at no pains to conceal it. In I799, the Hartford North Association went so far as to declare that its churches were "not Congregational"; and in 1805 , the General Association, with reference to the Saybrook Platform, called it " the ecclesiastical constitution of the Presbyterian church in Connecticut." Such words could never have been used to describe the condition of things in Massachusetts where the Cambridge Platform guided the action of the churches. But it is hardly surprising, in view of the course of events in Connecticut, to find the churches there, at the beginning of the nineteenth century, entering into fraternal relations with the General Assembly of the Presbyterian church, and undertaking a common task in the extension of organized religion westward, under the "Plan of Union," to be considered later in our study.

1 In 1818 , the adoption of a new constitution by the state placed all churches upon an equality before the law. 


\section{RELIGION AND THEOLOGY IN THE EIGHTEENTH CENTURY}

To understand an age, one must know what books the people read. It is not difficult to answer that question for the New England of the eighteenth century. The people read the Bible, and Pilgrim's Progress, and Baxter's Call to the Unconverted, and Law's Serious Call to a Devout and Holy Life; and their children studied the New England Primer. I do not mean to say that no other books than these were accessible to our ancestors, or that nothing else was ever read, but the books I have mentioned were among the classics of Puritan literature, and some of them were certain to be found in every home. Their perusal stimulated introspection, and cultivated a type of religious life which easily might, and not infrequently did, become morbid. And at the best, while it no doubt strengthened moral purpose and deepened piety, it ignored certain fundamental human instincts, and left undeveloped certain valuable capacities. Its onesidedness is seen in the "memoirs" of prominent men and women, which are in no proper sense biographies, but for the most part records of religious experience and expressions of pious sentiment. The same is true of much of the correspondence of the period, so far as that has survived. Even within the nineteenth century, one can find numerous instances of memoirs which lack all ordinary biographical information, and letters which are religious essays and nothing more.

There was, however, a more ambitious native literature, dealing, of course, with religion, and the Massachusetts Bay Colony had its Milton in the person of Michael Wigglesworth, and its epic in The Day of Doom. The literary merit of the poem was not remarkable, but it was widely read, and not without a shudder. It related how, at the last great 
day, non-elect infants would argue their desperate case with the Almighty, and argue in vain. The closing scene depicts the unfortunate infants, with heroic resignation and unimpeachable orthodoxy, acknowledging the justice of the sentence of condemnation pronounced upon them:

The glorious King thus answering,

They cease, and plead no longer;

Their consciences must needs confess

His reasons are the stronger.

The chief prose work of the early colonial period was Cotton Mather's Magnalia, which has been called the prose epic of New England. It is an extraordinary combination of history, theology, and controversy, - all permeated by the author's particular prejudices and superstitions, - but invaluable to the student of the period.

The New England Primer had a large and uninterrupted circulation for more than one hundred years, and it was the text-book for several successive generations of children. ${ }^{1}$ It opened with the alphabet, as all well ordered primers should; then were given lists of short and easy syllables; then lists of words, of growing difficulty. In its general form it was modelled after similar books published in England, but it contains significant changes. The Elizabethan primers usually had the cross of Malta ( $\mathbf{W}$ ) at the beginning of the first row of letters of the alphabet, but the New England Primer omits the priestly symbol. It will have none of the " cris cross row" (Christ's Cross row) of its prelatical predecessors, but will be avowedly puritan. The distinctive feature of the Primer was the alphabetical series of rhymed couplets, beginning,

\section{In Adam's fall}

We sinned all

1 It was first printed about 1690. Paul Leicester Ford estimates that it had an average annual sale of more than twenty thousand copies for at least one hundred and fifty years. See his monograph, The New England Primer (New York, I899). 
and ending with the triplet,

Zacchaeus he

Did climb a tree

His Lord to see.

With each was a decorative illustration of the incident to which the lines referred. To many a New England boy was assigned the unwelcome, but not very difficult, task of committing the entire series to memory, - as a punishment.

What was just said about Puritan antipathy to the symbol of the cross finds further illustration in the successive revisions of the Primer. The earliest edition had for the letter $\mathrm{J}$ this couplet:

Sweet Jesus he

Died on the tree

and there was an accompanying picture of the cross. But this was presently omitted, and in its place we read,

Job feels the rod,

Yet blesses God.

It was not the doctrine of the crucifixion which offended, but the pictorial representation of it. Good evidence of this exists in an edition of the Primer issued shortly after the Great Awakening, in which practically all the secular rhymes of the older editions are replaced by others of a religious nature. Under the letter $\mathrm{C}$, the earlier editions had the worldly-wise lines,

The cat doth play,

And after slay.

The new edition has the strongly evangelical

Christ crucified

For sinners died.

But now there is no picture of the crucifix. Belief in the 
atonement, wrought by the sacrificial death of Christ, was general in puritan New England. But the sign of the cross, like the cross itself among men of the ancient world, was a stumbling-block and foolishness.

The Primer also contained the Shorter Catechism, the Apostles' Creed, the Ten Commandments, and the Lord's Prayer. The Poem of John Rogers, first of the Marian martyrs, and his picture, as he was burning at the stake, surrounded by his large and sorrowing family, will perhaps be remembered by some who read these pages. New England's special contribution to the Primer was John Cotton's "Spiritual Milk for Babes, drawn out of the Breasts of both Testaments," which had considerable currency as a catechism for the young, although it never was so widely used as the Shorter Catechism of the Westminster divines.

On such food as this was the youthful mind of New England nourished for generations. It made life serious, but it gave it religious motive and direction, which the more latitudinarian ages have often lacked. There was, however, beginning in the eighteenth century, a new body of reading matter coming into existence, in the shape of newspapers. The Boston News Letter began publication in I704, and in the course of fifteen years, built up a circulation of three hundred copies. The Boston Gazette dates from I719, and the New England Courant from only two years later. ${ }^{1}$ Before very long we meet with the New England Weekly Journal, and the Boston Evening Post. Here, indeed, were the humble beginnings of a new era, the era of the newspaper, - that indispensable modern convenience, which has done so much to inform men, and at the same time to destroy their interest in the great literatures of the world.

1 Justin Winsor describes the Courant as "bold and saucy." It certainly lacked respect for tradition, and even ventured to print some of the hymns of Isaac Watts, suggesting that they be substituted for the Psalms in public worship. 
Reference has already been made to the evangelical revival of the eighteenth century, commonly known as the Great Awakening, and we must now turn to a consideration of the leaders of that movement, particularly Edwards and Whitefield, two of the most impressive figures in the religious history of America.

In the year of the new Massachusetts charter there was graduated from Harvard College Timothy Edwards, who became pastor of the church in Windsor Farms, Connecticut, and remained there for sixty-three years. He married a daughter of Solomon Stoddard, the well-known minister at Northampton, whose pastorate was also of notable length, covering sixty years. From this union was born, in the year r 703, a son who was destined to become the foremost philosopher and theologian of America, - Jonathan Edwards. John Wesley, the evangelizer of England's common people, was born the same year. The foundations of Petrograd were being laid under Peter the Great. The Royal Academy of Berlin was only three years old, and Leibnitz was its president. Bayle's Dictionnaire Historique et Critique, of which the second edition had just appeared, was profoundly stirring the European world. Voltaire was a boy of ten. At home, Yale College had just been founded, to become the nursery of Edwards and many of his followers.

The youthful Edwards exhibited extraordinary precocity. At the age of nine he wrote a serious discussion of the philosophy of materialism. At thirteen, he read Latin, Greek, and Hebrew. At seventeen, he was graduated from college with the highest honors. Soon called to a tutorship at Yale, when the college was face to face with a grave crisis, caused by the defection of its rector and tutor to Episcopacy, it fell to Edwards's lot to recover the institution from this staggering blow, and set it anew upon its appointed pathway. He succeeded, but at the cost of much labor and peace of mind. 
"I have now," runs his Diary (June 9, I 724), " abundant cause to be convinced of the troublesomeness and perpetual vexation of the world."

Three years passed, and Edwards accepted the associate pastorate, with his grandfather, of the church in Northampton, where he remained for twenty-three years, until dismissed on account of his opposition to the Half-way Covenant, and because his rigorous moral standards were disliked by the young people. To the lasting discredit of what is now, by way of tardy atonement, the "Edwards Church" of Northampton, he, the foremost thinker of New England, at the very height of his powers, was cast out, to shift for himself and his family as best he might. Half a dozen years followed of frontier life among the Stockbridge Indians, where he wrote his Treatise on the Freedom of the Will, and he was then called to become president of the infant College of New Jersey. He removed to Princeton, but only to die within two months from the effects of inoculation for the smallpox. ${ }^{1}$

With Edwards begins a new period in our religious history, a period characterized on the one hand by revivalism and on the other by the appearance of theological parties and the growth of denominationalism. He himself was the founder of one of the most influential schools of theology produced by America, known as the "New England School," which lasted for more than a century. And it was in no small measure a reaction against Edwardeanism that produced the liberal movements which have played so interesting and significant a part in modern New England thought.

1 A genealogical study of Edwards's numerous descendants reveals very interesting facts. It has been computed that there are among them presidents of eight colleges, about one hundred college professors, more than one hundred lawyers, sixty physicians, thirty judges, eighty holders of important public office, twenty-five officers in the army and navy, and almost numberless clergymen and missionaries. See Edith A. Winship's article on "The Human Legacy of Jonathan Edwards," in the World's Work for October, 1903 . 
Most persons have at least heard of Edwards's sermons on the terrors of future punishment, but few are familiar with his finer and more characteristic sermons on "Man's Dependence," and "Spiritual Light." His "Treatise on the Will" remains his most famous work, but the essays "On the Religious Affections," "On Virtue," and "On the End of God in Creation," are quite as valuable as an index to his thinking, and would of themselves have ensured him a permanent place in the history of religious literature. $\mathrm{He}$ was intensely interested in the subject of conversion, and analyzed the soul's experience with the utmost keenness. It was not primarily the psychological importance of the phenomena which attracted him, but rather the fact that here he witnessed the workings of the Holy Spirit upon the human heart and will. He sought to trace each step of the process, and to describe it accurately for the benefit of others. The revivals, which began in I735, afforded ample opportunity for such investigations, and one may read of a typical case, in the Life of the Rev. David Brainerd. The reality and decisiveness of Brainerd's conversion are thus set forth by Edwards:

The dispositions and affections which were then given him, and thenceforward maintained in him, were most sensibly and certainly, perfectly different in their nature from all that ever he was the subject of before, or that he ever had any conception of. . . . It is further observable that his religion all along operated in such a manner as tended to confirm his mind in the doctrines of God's absolute sovereignty, man's universal and entire dependence on God's power and grace, etc. . . . Now where is there to be found an Arminian conversion or repentance, consisting in so great and admirable a change ? (Edwards's Works, I, pp. 664 f. New York, I858).

Yet Edwards was far removed from sympathy with the fanatical type of revivalism practiced by some less cultivated preachers, and he alludes to it with severity, lamenting that 
there have been "so many pretences and appearances of what is called experimental vital religion," which, in the end, "have proved to be nothing but vain, pernicious enthusiasm" (Works, I, p. 662).

The Great Awakening was immensely stimulated by the preaching of a young English clergyman, George Whitefield, who made seven visits to America, and showed himself the greatest popular preacher of his time, and one of the greatest of all time. His audiences overflowed the largest churches, and it was estimated that, in the open air, he sometimes addressed as many as twenty thousand persons. Like his contemporary, John Wesley, he preached assiduously, averaging two sermons a day for most of his active life. In all it is said that he preached about eighteen thousand sermons. And they were by no means short. The day before his death he preached one hour and fifty-five minutes. ${ }^{1}$ The effects of his oratory were remarkable, and whole communities were transformed through his influence. But he yielded to the temptations which beset popular revivalists, adopting a tone of censoriousness towards churches and ministers, and denouncing the colleges, where, he said, the light had become darkness. He himself, in his turn, was severely criticized, not only by individuals, but also by the colleges and the newspapers. ${ }^{2}$ Even the gentle Edwards felt constrained on one occasion to administer to him a reproof.

The general description of Whitefield and his work given by Benjamin Franklin, who knew him personally, is so candid and so fair, that it deserves to be quoted at length:

1 At Exeter, N. H. See Stiles's Diary, Nov. I 2, I770.

2 "The Testimony of the President, Professors, Tutors, and Hebrew Instructor, of Harvard College, against the Rev. George Whitefield and his Conduct," issued in December, 1744 , and the "Declaration of the Rector and Tutors of Yale College against George Whitefield," issued in February, 1745. Timothy Cutler, then rector of Christ Church, Boston, abused Whitefield roundly, and he was ridiculed in the columns of the Boston Evening Post, which had lately come into existence. 
In 139 arrived among us from Ireland the Rev. Mr. Whitefield, who had made himself remarkable there as an itinerant preacher. He was at first permitted to preach in some of our churches; but the clergy, taking a dislike to him, soon refus'd him their pulpits, and he was oblig'd to preach in the fields. The multitudes of all sects and denominations that attended his sermons were enormous, and it was matter of speculation to me, who was one of the number, to observe the extraordinary influence of his oratory on his hearers, and how much they admir'd and respected him, notwithstanding his common abuse of them, by assuring them they were naturally half-beasts and halfdevils. It was wonderful to see the change soon made in the manners of our inhabitants. From being thoughtless or indifferent about religion, it seem'd as if all the world were growing religious. ${ }^{1}$

A breathlessly enthusiastic account of the field preaching of Mr. Whitefield in Connecticut is found in an old diary, kept by an illiterate farmer named Nathan Cole. This tells us how Cole and his wife, in feverish haste, rode iwelve miles on horseback to hear the great preacher, and it thus describes the impression his appearance produced upon them:

He looked almost angellical a young slim slender youth before some thousands of people \& with a bold undainted countenance . . . it solumnized my mind \& put me in a trembling fear before he began to preach for he looked as if he was Cloathed with authority from ye great god, \& a sweet sollome Solemnity sat upon his brow. . . . ${ }^{2}$

There were naturally many who defended Whitefield against all aspersions, and heartily endorsed his work. Benjamin Colman and Thomas Prince were instrumental in securing a statement, signed by ninety ministers, in which they bore public testimony to the value of the revival meetings, and as for their general popularity, that was obvious enough to all beholders. It is estimated that during the twenty years from I 740 to I 760 , one hundred and fifty new

1 Autobiography, edited by William Macdonald, I905, p. 125.

${ }^{2}$ Quoted from the unpublished diary, by Dr. G. L. Walker, Some Aspects of the Religious Life of New England, Boston, I897, p. 91. 
churches were established in New England. ${ }^{1}$ To this number should be added many more in the central and southern colonies, - for Whitefield travelled widely and preached everywhere. Gains were registered by all the churches, Baptist, Methodist, Presbyterian, and even Episcopalian, as well as by the Congregationalists. But it should be added that the increase in membership in the Episcopal church was due in part to the reaction against the revivals, felt by members of the other churches, who disliked Whitefield's extravagances, and withdrew from the churches where they were encouraged. A fresh interest in Christian education led to the foundation of Dartmouth College, as an outgrowth of Moor's Indian Charity School at Lebanon, Connecticut, and also to the foundation of Princeton College, so that both these institutions may be regarded as indirect fruits of the revival movement.

One of the by-products of the Great Awakening was an outbreak of simon-pure congregationalism in eastern Connecticut, in the shape of a series of local separations from the dominant ecclesiastical system of the Saybrook Platform. The persons most actively engaged in it were ignorant and humble folk, like Nathan Cole, but very much in earnest, and insistent upon their right to conduct their religious affairs after their own fashion. They believed in evangelism of the vigorous, enthusiastic type, and they were impatient of the conservatism with which they were surrounded. The last synod ever called by the colonial authorities of Connecticut was convened to consider these irregularities, and its adverse action was followed by legislation by the General Court, making separation from the standing order illegal. As a consequence, the people who had formed conventicles, - just as the progenitors of New England had done across

1 The population of New England about the middle of the eighteenth century has been estimated by Justin Winsor at four hundred thousand persons. 
the sea, - found themselves persecuted for their faith. So vigorous was the action against them, that we even hear of the expulsion of two students from Yale College in I744 for the offence of having attended a separatist meeting. The movement, however, was not well organized or efficiently led, and it died out without permanently affecting the course of ecclesiastical history. Yet it is of interest to the student because of the anomalous situation which it created, in bringing a commonwealth whose origin lay in Puritan separatism into the position of a persecutor of independent movements within its own body. ${ }^{1}$

Another of the effects of the Great Awakening, and not the least important, was the formation of theological parties, and the sharpening of such doctrinal distinctions as already existed. Thenceforward polemical preaching flourished in New England, and theological liberalism entered upon a vigorous and successful stage of its career. The Edwardean system, under the name of "New England Theology," or Hopkinsianism, was transmitted, through a line of able thinkers and writers, almost to our own day. Joseph Bellamy and Samuel Hopkins, with Edwards himself, constituted the great triumvirate, and among their best known successors were Nathanael Emmons, Jonathan Edwards, Jr., and the elder Timothy Dwight. Some of the members of this school, like President Finney and Professor Nathaniel W. Taylor, mark a departure from the severities of the system as handed down to them, which simply means that they construed more liberally than their associates the Hopkinsian principle of theological "improvements." All these divines were Calvinists, but they maintained that their Calvinism was an improvement upon Calvin's. They taught that all holiness consists in disinterested benevolence, and

1 S. L. Blake, The Separatists, or Strict Congregationalists of New England. Boston, 1902 . 
that all sin consists in selfishness. The supreme test of a man's faith was held to be his willingness to be damned for the glory of God. The searching nature of this test, when applied to a sensitive conscience, is admirably depicted by Mrs. Stowe, in The Minister's Wooing, which is one of the best pictures of the religious life of New England ever painted. ${ }^{1}$

Ezra Stiles, who, although an evangelical, was not himself in sympathy with the new divinity, records a striking incident which fell under his immediate observation, and seemed to him to supply the reductio ad absurdum of the whole Hopkinsian movement. It was the case of a Mr. Dawson, an independent Baptist minister of Newport, in the very year when Samuel Hopkins was called to the pastorate of the Congregational church of that town. I quote from Stiles's letter describing Dawson: ${ }^{2}$

He preaches that it is sinful for the unregenerate to pray at all; to use the Lord's Prayer in particular, for if they said the truth, they would say. ... " Our Father which art in Hell," our father, the Devil: that unregenerate are to use no means at all, there are no means appointed for them; . . . they are more likely, or at least as likely, to be seized by grace, not using than using means. Particularly, as to attending his preaching, he asked them what they came there for, he had nothing to say to them, only to tell them they were heirs of damnation, and that would do them no good nor hurt. . . . None but saints were the subjects of his preaching or ordination; and [he] forbid at length the promiscuous congregation to sing with them, or pray with them, - and only a dozen or so now sing. . . . So that he does the thing thoroughly, - he makes no pauses or reservations. Now this, at this time, is a very wonderful looking-glass! [Italics mine.]

In this "looking-glass" Stiles would have had all adherents of the "new divinity" behold their likeness, if only

1 The student should consult F. H. Foster's Genetic History of the New England Theology, Chicago, 1907.

${ }^{2}$ Letter from Ezra Stiles to the Rev. Chauncey Whittlesey, March 6, I770. Diary, I, pp. $40 \mathrm{f}$. 
they would carry out their principles to logical completeness. But that seldom happens in theology, for the sufficient reason that its materials transcend the laws of logic. Too many factors are involved to permit any one of them free operation at the expense of the rest.

Over the issues raised by the Edwardeans the ranks of orthodoxy were divided, as we have seen, into Old Calvinists and New Divinity men, and this cleavage runs through nearly a century, never involving organic separation, but furnishing repeated occasions for debate. The party name, " Old Calvinists," did not come into use at once, but only by degrees, to distinguish them from the other group. Dr. Leonard Bacon once described them as "Calvinists of a mitigated type." They did not deny that salvation was wrought by divine grace, according to the sovereign will of God, but they did encourage the use of "means," such as prayer, church attendance, Bible reading, pious meditation, and righteous living, - which the thorough-going Hopkinsian repudiated, as in no possible sense efficacious for salvation. Through such "means," the Old Calvinists believed that man might place himself in the way of receiving the grace of regeneration, although he could not earn it. Their position marks a slight approach to the Arminianism which Edwards so severely reprobated. The foundation of Andover Theological Seminary, in 1807 , may be said to mark the reconciliation of the two wings of orthodox Congregationalism.

Over against both these orthodox groups stands the " new Arminianism," against which Edwards contended throughout all his later life. Enemies of Calvinism alleged that it was antinomian in its tendency, that it failed to offer any sufficient ethical motive, that it placed stumbling-blocks in the way of men, and that their own view of religion, which laid greater emphasis upon moral responsibility, must always present the stronger appeal. It was a revival of the 
theological issues which had been fought over in Holland in the days of Arminius, and in the ancient church during the Pelagian controversy. Popularly the issue might be stated thus: Calvinism holds that God saves men; Arminianism holds that men help to save themselves. The more radical view, that men save themselves, which of course would empty the term "salvation" of all Christian content, was not advocated by anyone in the early days of New England liberalism. The most vigorous protests were directed against those aspects of Calvinism which, as the liberals believed, were degrading to human nature and made an artificial distinction between the morality of the regenerate and that of the unregenerate. "The best actions of the unregenerate," said Experience Mayhew, one of the earliest of the liberals, " are not properly called sins." 1

Jonathan Mayhew, son of Experience, preached that "regeneration is conditioned on the earnest efforts of good men to obtain it," and this position may be said to have held the field among all advocates of an advanced theology. Jonathan Mayhew went further than most of his contemporaries, even among the liberals, in reviving Arian views of Christ, and setting aside the orthodox doctrine of the Trinity. He thus anticipated the development of Unitarianism in the nineteenth century. More moderate was the position of Charles Chauncy, pastor for many years of the First Church of Boston. His sympathies were in line with the doctrinal relaxation, but he was a conservative-liberal, and his influence was large and beneficent in an age of increasing theological difficulty. Towards Mayhew, Chauncy stood in somewhat the same attitude that Channing afterward occupied towards Theodore Parker.

As we reach the period of the American Revolution, it may fairly be said that, in New England, the Arian views of

1 See his Grace Defended, 1744. 
Christ were no longer a novelty, that the orthodox view of original sin was widely contested, and that the doctrine of eternal punishment was much in doubt, if not openly rejected by many. Conditions were becoming favorable for the formation of the Universalist and Unitarian denominations, - the two groups of organized liberals of America.

There was, however, another religious movement, very different in origin and nature from those we have noticed, which operated powerfully to modify the strictness of American theology, and that was Methodism. John and Charles Wesley, in the course of their remarkable evangelistic work in England, vehemently opposed certain tenets of Calvinism, and most emphatically declared that men are responsible to God for their conduct, and have no excuse for idly waiting for the Holy Spirit to convert them. At the same time, they heartily believed that conversion was a supernatural change. This type of Arminianism was presented in the form of earnest religious appeal by preachers in the field, not by theologians in the study, and it laid hold on the popular imagination with singular power, winning thousands of converts.

The first Methodist preacher to visit Boston was Jesse Lee, who in 1789 conducted open-air meetings on the Common, with a large attendance but little apparent result. "The Word took but little hold on the mind of the hearers," - was Lee's mournful verdict upon his visit. In fact, Methodism did not make much progress in New England until after the beginning of the nineteenth century, yet its theological influence was doubtless at work there, affecting even those who were outside its pale. In Methodism one could find visible evidence of the fact that evangelical religion lived, and lived potently, apart from some of the most cherished theological beliefs of puritanism. That may fairly be said to have been a discovery for New England. And by it the whole Christian world was enriched. 
The period of the American Revolution was a time of difficulty for all the churches, but particularly for those, like the Episcopal and Methodist, which had close connections with the mother country, and were, through the Anglican establishment, in some sense under its jurisdiction. When, in I 769 , Ezra Stiles includes among the "trials and difficulties" which are troubling his mind, "concern for the Congregational churches, and prevalence of Episcopacy and wickedness," we should be far astray if we regarded the statement as a piece of sectarian bitterness, and even more so, if we thought him endeavoring to be humorous. The fact is that the ambitious schemes of the Episcopal church in New England were hardly less a cause of the revolt of the colonies than unjust taxation, or any of the other oppressive acts against which the colonists complained. John Adams, writing in I8I 5, of the views and suspicions of New Englanders fifty years before his time, remarked that "if Parliament can erect dioceses, and appoint bishops, they may introduce the whole hierarchy, establish tithes, forbid marriages and funerals, establish religion, and forbid dissenters." In other words, the colonists feared that, through the church, the English state could greatly strengthen its hold upon America. The immediate fear was that bishops might be introduced into New England, but the war brought all such apprehensions to an end.

The other churches were less seriously affected by the Revolution. Their forms of organization enabled them to continue their institutional life, with no more interruption than would be inevitable under the circumstances, and they readily adapted themselves to the changed political conditions brought about by the union of the colonies into the United States of America. During the eighteenth century it had been generally, although not universally, believed that the civil government might and should lend its 
support to organized religion. But when the federal constitution was adopted, and again in the series of new state constitutions which followed, the principle of the separation of church and state was recognized as the best possible for the new republic. This change of opinion was due to several causes, among them being the multiplicity of rival sects, which made it impracticable to extend public favors to any of them; the positive objections to any connection between government and religion, felt by many; and the rise of the theory of the secular state, through the influence of Jefferson and his sympathizers, who in their turn had been influenced by the French political philosophy of the period. It became a settled principle of the American people that church and state should be kept apart for the good of both. Every attempt to abandon this principle has met with open and so far effectual opposition. Yet it is to be observed that the change was not effected at once in all parts of New England. In the towns especially, which retained most of their old autonomy, the public support of the churches did not cease in Connecticut until $18 \mathrm{r} 8$, and in Massachusetts not until I833.

The closing years of the eighteenth century witnessed the consolidation of the religious forces of the country, the creation of new ecclesiastical machinery where it was needed, ${ }^{1}$ and a fair start of the various denominations under the competitive system which the divorce of church and state rendered inevitable. The equalizing of ecclesiastical opportunity, and the mutual recognition of one another's rights, was still a novelty, and it long continued to impress foreign observers, as it had impressed one in the town of Philadelphia, before the outbreak of the Revolution: "Papists,

1 The Methodists, for instance, received a "Superintendent " from John Wesley, and the Episcopalians secured ordination for their bishops at the hands of the Nonjurors of Scotland and the Archbishop of Canterbury, thus uniting the long separated English lines. 
Episcopalians, Moravians, Lutherans, Calvinists, Methodists, and Quakers passing each other peacefully and in good temper on the Sabbath, after having broken up their respective assemblies." 1 The spectacle astonished this European visitor, for such concord was unknown across the sea. It has become so familiar to us that we have lost all sense of its significance and of its intrinsic worth.

The changes which had come over the religious aspect of New England during one hundred years may be exhibited by a statistical summary. About the year I 700 New England as a whole contained one hundred and ten Congregational churches and one Episcopalian church. About I 800 , there were in Massachusetts alone three hundred and forty-four Congregational churches, besides one hundred and fifty-one of other denominations. Among the latter were ninetythree Baptist, twenty-nine Methodist, fourteen Episcopalian, eight Quaker, four Universalist, and two Presbyterian churches. ${ }^{2}$ The first Roman Catholic church in New England was built in Boston in the year $1800 .^{3}$

Our statistical summary suggests what was the fact, that thus far, Presbyterianism had made little headway in New England. That little was due for the most part to the coming of a Scotch-Irish company to Londonderry, New Hampshire, in I720. Here was organized the first genuine Presbyterian church of New England, and here that polity has remained in vigorous life through all the intervening years.

1 See Diman, Orations and Essays, p. 216.

${ }^{2}$ J. S. Clark, Historical Sketch of the Congregational Churches in Massachusetts, Boston, 1858 .

3 As Dr. O'Gorman puts it, "In all New England there was no building worthy the name of church until Dr. Matignon, in I800, began the erection of one on Franklin Street in Boston." (History of the Roman Catholic Church in the United States, p. 282.) O'Gorman gives the Roman Catholic population of Boston in 1798 as two hundred and ten persons. 


\section{MODERN CONGREGATIONALISM}

THE spirit of individualism was always strong in New England. It is inherent in all forms of protestantism, but showed itself especially in connection with the Puritan movement, both in England and in America. And as the eighteenth century drew near its close, there were heard, with increasing clearness, voices of protest against the traditional Calvinistic teaching. They were demanding release from the intolerable burden of belief in inherited guilt, under which the souls of men were staggering, and the recognition of a moral order in which the son should no longer bear the iniquity of the father, but everyone should be judged according to his own ways. They demanded a simplification of the Christian message, and their summons marks the transition from what has been called the metaphysical to the ethical period in our religious history.

We have seen that many factors entered into this movement of emancipation, but among them we must not overlook the beginnings of the historical study of the Bible, under the leadership of Protestant scholars in France and Germany, which necessitated a reconstruction of current ideas respecting the authority of Scripture, and a changed conception of the development of Christianity. Nor may we overlook the growth of modern democracy, with its social readjustments and their bearing on the religious ideas of men. Mr. Lecky would attribute almost all the transformations of religious belief to this cause. "If," he writes, " in the sphere of religion, the rationalistic doctrine of personal merit and demerit should ever completely supersede the theological doctrine of hereditary merit and demerit, the change will mainly be effected by the triumph of democratic principles in the sphere of politics." I But into the discussion of this

1 Quoted by Professor Diman, Orations and Essays, p. 233. 
attractive theme we cannot enter here. We must rather consider the liberalizing forces which proceeded from within Congregationalism itself, and which exhibited the historical working out of certain distinctive traits of the New England character.

Unitarianism, broadly speaking, stands for an abrupt emancipation from scholastic orthodoxy. In its organized form, it presents one aspect of an intellectual and theological development, very much broader than itself, which is clearly traceable in all the leading protestant churches of Europe and America, and from which all have reaped substantial benefits. Just as in the ancient church the Gnostic movement may be, and has been, described as the "acute hellenization of Christianity," - so in modern protestantism the Unitarian movement might be described as the acute liberalization of Christianity. And just as, in the former case, it is clear that Gnosticism was not the cause, but rather one immediate effect, and that the most conspicuous, of deep, underlying causes, working towards the formulation of the comprehensive ancient catholic system, so, in the latter case, it is equally clear that Unitarianism was not the cause, but rather one immediate effect, and again the most conspicuous, of deep underlying causes, working towards the formulation of a simpler, more comprehensive, more ethical, and not less Christian, programme for the churches of the modern world. Regarding the Unitarian movement from this point of view, one may reasonably hope to avoid envelopment in the dust and smoke of theological battle, and to measure with some degree of justice the value of its service to the cause of religious progress.

It so happens that, on the ecclesiastical side, the first steps in the creation of an organized body of liberals were taken among the constituents of this very church where we 
are now gathered. King's Chapel lost most of its original members in consequence of the Revolution, for they were Tories. Hardly was the war over, and the federal government securely established, when the congregation worshipping here elected and installed a liberal minister in the person of James Freeman, and introduced drastic modifications of the liturgy, expunging most of the trinitarian phraseology. This first Unitarian church in America may be dated from I785, the year when the altered book of worship was officially adopted. ${ }^{1}$ The formal induction of Mr. Freeman into office, as " Rector, Minister, Priest, Pastor, teaching Elder, and public Teacher" of the religious society of King's Chapel, did not take place until two years later, in November, 1787. The ordination ceremony was performed by the senior warden, setting a precedent which has ever since been followed. ${ }^{2}$ Under the old regime, when the Chapel was still subject to Anglican control, it held the right of presentation and chose its own rectors, and this right was recognized by the Bishop of London. But the induction of the incumbent into office by the congregation, through its local officers, acquired a new significance after the separation of the colonies from the mother country and the mother church. The essentially Congregational character of these proceedings has often been pointed out, and it has especial interest for orthodox Congregationalists at the present time, when modifications of polity, looking in the opposite direction, are in favor with many leaders of the denomination.

This act of independent ordination was much discussed and bitterly criticized, and it was repudiated by the other Episcopal churches of New England. But defenders were not lacking on the Congregational side, especially among the

1 The first revision consisted chiefly of changes suggested by the English liberal, Dr. Samuel Clarke. There were further revisions in 1811,1828 , and even later.

2 Application for Freeman's ordination had been made to the recently consecrated American bishop Provoost, of New York, but without success. 
advanced liberals. Dr. Belknap, pastor of the Federal Street church, gloried that it had been performed " without any affected communication of sacerdotal effluviae." His exultant and perfervid rhetoric is worth quoting:

Then was cut the aspiring comb of prelatic pride, - then was undermined the pompous fabrick of hierarchical usurpation; - then was pricked the puffed bladder of uninterrupted succession; while the eye of liberty sparkled with joy, and the modest face of primitive, simple, unadulterated Christianity brightened with the conscious smile of a decent, manly, substantial triumph. ${ }^{1}$

The Pilgrim church in Plymouth, and a large number of the churches of eastern Massachusetts, one after another adopted Unitarianism as their faith, and the divisions which ensued were marked by a bitterness of feeling which lasted through the century. Only one of the colonial churches of Boston maintained its orthodoxy, the Old South. Within a radius of twenty-five to thirty miles from the State House, a majority of the "first parishes" swung into line with the new movement, and Harvard College allowed its sympathy and coöperation to be seen in the election of a liberal, Henry Ware, to the Hollis Professorship of Divinity. But Unitarianism was narrowly localized, and for a long time met with little favor beyond the limits mentioned.

In opposition to the rising tide of liberalism, we find the Hopkinsians and Old Calvinists joining forces in the establishment of Andover Theological Seminary, with generous provision for the training of orthodox ministers. On its faculty were soon to be found some of the ablest defenders of the older faith. Party publications began to appear, and learned disputations were put forth by champions on both sides of the great controversy. In the columns of the Monthly Anthology and the Christian Disciple one might

1 From an article in The Centinel, quoted by Greenwood, History of King's Chapel, p. Ig6. 
read what the liberals believed and desired, while in the Panoplist and the Spirit of the Pilgrims were published the defences of the orthodox. Professor Leonard Woods of Andover published a series of Letters to Unitarians, and Professor Ware of Harvard, a similar series of Letters to Trinitarians and Calvinists. The Convention Sermon gave opportunity for the public discussion of both sides of the questions at issue. Channing's sermon at the installation of Jared Sparks in Baltimore (I8Ig) fired a liberal broadside, to which Professor Moses Stuart, - the ablest of all the disputants, - issued a reply. This in turn evoked a counter-reply from Professor Andrews Norton. And so the battle raged. A large part of the energies of Congregationalism in eastern Massachusetts for an entire generation were absorbed by this acute and bitter theological controversy.

The organization of the American Unitarian Association in 1825 gave denominational existence to what before had been simply the liberal party of Congregationalism. The chief point of attack upon orthodoxy was not in the field of theology proper, as the name "Unitarian" would seem to imply, but in that of anthropology. It was the Calvinistic view of human nature which provoked Channing's bitter arraignment of traditional dogmas. Only later was attention shifted to the doctrine of the Trinity. And the best service which the liberals rendered to religious progress was in helping to free the minds of men from their burden of belief in inherited guilt.

Emerson's "Divinity School Address" (I838), and Theodore Parker's sermon on "The Transient and Permanent in Christianity" (I84I), shortly followed by the death of Dr. Channing, who had been the acknowledged leader of the older liberals, introduced a new chapter in the development of American Unitarianism, more radical than the first and more obviously a depariure from historical Christianity. 
From this time onward there may be said to have been a conservative and a liberal party among the Unitarians, as in most other protestant churches of modern times.

Where churches were divided in opinion and a split was threatened, as was often the case, a momentous question arose, viz., which fraction constitutes the real church, and which the schismatic body. This question was hotly contested, for upon its decision depended the name, the records, and the property of what might be an ancient and wealthy church. The issue was not so simple as it might appear, for, under the laws of the commonwealth, two distinct organizations were involved, the church and the parish. Where a clear majority of the church members remained orthodox, as in the church at Sandwich (99 out of II3), they naturally supposed that the rights and property would remain theirs. But the parish, Unitarian by a majority of two or three, ${ }^{1}$ contended that in it resided all the legal rights, and the case being taken to the courts, a decision was given in favor of the parish. A similar decision was handed down by the Supreme Court of Massachusetts in the Dedham case, which formed a precedent for all subsequent action. It ran as follows:

When the majority of a Congregational church shall separate from the majority of the parish, the members who remain, although a minority, constitute the church in such parish, and retain the rights and property belonging thereto.

The action of the courts affected eighty-one churches, and it has been computed by Dr. Dexter that under it three thousand nine hundred church members surrendered church property and records to one thousand two hundred and eighty-two, - the ratio being about three to one. ${ }^{2}$ The many Burr.

1 The vote was taken on a motion to dismiss the (orthodox) minister, Jonathan

2 H. M. Dexter, The Congregationalism of the Last Three Hundred Years, p. 6 rg. 
orthodox majorities in the churches of eastern New England were not only astonished at the decision of the court, but profoundly indignant. They were astonished, because they saw that, according to the court, a church in and of itself had no legal existence whatever. Thus, Chief Justice Parker declared that "a church cannot subsist without some religious community to which it is attached." And again, "As to all civil purposes, the secession of a whole church from the parish would be an extinction of the church." And the orthodox majorities were indignant, because property and rights were seen passing into the legal possession of minorities, a transaction which seemed to them to violate every inherited principle of fair play. They believed that the action taken under the court's ruling was little short of "legalized plunder." And as a natural consequence, we find in many places two rival bodies, each claiming to be the "First Church," although legally only one of them, - and that usually the liberal, - was entitled to that name.

In point of law, which is after all what the courts had to pass upon, it is difficult to see how any other decision was possible than the one actually rendered. But in point of equity, the case is different. And one of the cheering signs of recent years has been to find the two branches of some of the ancient churches entering into fraternal agreements, which frankly recognize the justice of their mutual claims. An instance in point is that of the two churches in Cambridge, which in I899, through friendly negotiations, agreed thenceforward to be known respectively as "The First Church, Unitarian," and "The First Church, Congregational," - a happy solution of a long standing difference.

One immediate consequence of the doctrinal controversy at the beginning of the nineteenth century was the foundation of theological schools, to take the place of the inadequate provision for ministerial education furnished by the 
colleges and by private training in the homes of ministers. We have already noticed the establishment of Andover Seminary in 1807 . This was the chief centre of Congregational education for many years, and its plan of organization and curriculum furnished the model for all the schools which came after it. A second Congregational seminary was established at Bangor, Maine, in I8ı6. A few years later we find a differentiation taking place at the colleges, and instead of a single professorship of divinity, - which had long been the rule both at Harvard and at Yale, ${ }^{1}$ - a department of theology was established, on the general plan of the independent schools already mentioned. Thus the Harvard Divinity School comes into separate existence, followed soon by Yale; the former Unitarian, and the latter Trinitarian. As the Yale School soon exhibited a theological tendency too liberal for some of its natural constituents, another institution was started at East Windsor Hill. This was dominated by the conservatives, and later was removed to Hartford, under the new name of Hartford Theological Seminary.

The detachment of theological instruction from the college curriculum and its incorporation into a separate department resulted not only in marked improvement in the facilities for theological training, but also in a further secularizing of the college proper; so that, in modern times, one hears the complaint that in the colleges too little rather than too much attention is devoted to religion. The beginnings of this change are found about the year I800.

American Congregationalism has proved itself remarkably productive of educational institutions of the higher grades. Within the confines of New England, besides Harvard and Yale, there are at least eight collegiate institutions which owe

1 The Hollis professorship at Harvard was founded in $172 \mathrm{r}$, and had only three incumbents before the appointment of Henry Ware. At Yale the Livingston (now Chittenden) professorship of divinity was founded in $\mathbf{1 7 4 6 . ~ I t ~ h a d ~ f o u r ~ i n c u m - ~}$ bents prior to the establishment of the department of divinity in 1822 . 
their origin to Congregational zeal and enterprise. These are, in the order of their foundation, Dartmouth, Williams, Bowdoin, Middlebury, Amherst, Mount Holyoke, Smith, and Wellesley. The last three suggest one of the most striking changes which have occurred within the realm of the higher education in modern times, - the opening of college doors to women. Outside of New England, Congregational enterprise has been no less marked, in connection with the drift of population westward, especially since I860. Some twenty colleges of good standing, scattered through the West, are proof that Christian education is still one of the cardinal principles of the denomination.

In connection with the westward expansion, although in one of its earlier stages, a scheme of coöperation, known as the "Plan of Union," was worked out between the General Congregational Association of Connecticut and the Presbyterian General Assembly. This provided for combined effort in planting new churches through central New York and northern Ohio, and declared that in each case the church should decide for itself with which of the two denominations it should be affiliated. A similar privilege of choice was provided for the ministers. The Plan contemplated that both Presbyterians and Congregationalists would probably be found in most of the churches thus formed, and it was believed to provide with fairness for the interests of both. In entering into this irenic project, the latent presbyterial proclivities of Connecticut Congregationalists found fresh expression.

The Plan of Union was well conceived, but in actual operation it brought ecclesiastical advantage to the Presbyterians. Their presbyteries were geographically nearer and more accessible; their polity seemed to the new churches more compact and stable; and, most important of all, it was a polity into which an independent church might readily 
enter, by voting to apply for membership, but out of which no church might pass without the approving vote of its presbytery. "On Congregational principles," said Dr. A. H. Ross, " a church may, by majority vote, carry itself and its property into a willing Presbytery; but on Presbyterian principles no church can withdraw from an unwilling Presbytery by majority vote." Large numbers of churches, which would naturally have been Congregational, became Presbyterian under this Plan.

On the other hand, the prevailing theology of these newly founded churches was of the New England type, and especially of the type represented at New Haven by Professor Nathaniel W. Taylor, a teacher of marked ability, but doctrinally displeasing to many conservative Congregationalists, and even more so to Presbyterians. The type of theological liberality, known as "Taylorism," stamped the young Presbyterian churches as objects of suspicion in the minds of Old School Presbyterians. At the meeting of the General Assembly in I837, the conservatives found themselves in the majority, and seized the opportunity to abrogate the Plan of Union. They claimed that it was null and void from the beginning, inasmuch as the General Assembly of I80I, which made the Plan, had no right to treat with the General Association of Connecticut, which was not a national body and in any event could not speak or legislate for the churches that composed it. And the Assembly went on to exscind four entire synods made up of the union churches. It remained for the Congregationalists to act, but this was difficult, for opportunities of collective action were not offered by their polity. When, however, the Albany Convention was assembled (1852), and the Congregationalists found themselves together for the first time since the colonies had become a nation, the question was brought up. The Convention cherished no delusions as to how the Plan of 
Union had actually worked. "They have milked our Congregational cows," said one speaker, "but they have made nothing but Presbyterian butter and cheese." There was little to be done except declare the Plan abrogated, which the Convention proceeded to do. It thus disappears from history.

The Albany Convention was the first general gathering of Congregationalists since the Cambridge Synod of 1648 , and it naturally leads us to the consideration of denominational development, as seen in the National Council of more recent times. A preliminary council, held in Boston at the close of the Civil War, marks the first step towards what has become a fixed institution, although the original call for this meeting did not contemplate its recurrence at stated intervals. Indeed, it was still a question whether Congregationalism provided any place for councils as a part of its denominational machinery. Over five hundred delegates were in attendance at Boston, and the two fundamental questions of faith and order received a large share of the Council's attention. On both there was vigorous debate, and considerable differences of opinion were developed. The main achievements of the Council were the adoption of an admirable statement of polity, presented by Professor Park of Andover, and a hastily prepared and on the whole rather insignificant statement of belief, known as "The Burial Hill Declaration" (I865).

The former statement runs as follows:

Resolved, that this Council recognizes as distinctive of the Congregational polity, - First, the principle that the local or Congregational church derives its power and authority directly from Christ, and is not subject to any ecclesiastical government exterior or superior to itself. Second, that every local or Congregational church is bound to observe the duties of mutual respect and charity which are included in the communion of churches one with another; and that every church which refuses to give an account of its proceedings, when kindly 
and orderly desired to do so by neighboring churches, violates the law of Christ. Third, that the ministry of the gospel by members of the churches who have been called and set apart to that work implies in itself no power of government, and that ministers of the gospel not elected to office in any church are not a hierarchy, nor are they invested with any official power in or over the churches. ${ }^{1}$

With regard to this document, Professor Walker remarks that "a Mather or a Cotton would have looked with astonishment on the statement that the duly established ministry implies "no power of government,"' and points out also that it gives expression to the more democratic type of Congregationalism, which had been developed in New England.

The question of creed involved more difficulty, for it appeared, in the course of the discussion, that there was some objection to the employment of the term Calvinist, to describe the theological position of the members of the Council. This objection evoked a spirited protest from Professor Park, which has been widely quoted: "We are Calvinists," he said, "mainly, essentially, in all the essentials of our faith. And the man who, having pursued a threeyears' course of study, - having studied the Bible in the original languages, - is not a Calvinist, is not a respectable man." Whatever may be the merits of his argument, with regard to which there is obviously room for difference of opinion, the Council finally allowed the offensive name to pass. But the statement of faith was a sentimental compromise, proposed at a meeting held on Burial Hill, on an excursion to Plymouth. It stood, indeed, as the only collective declaration of Congregational belief since the adoption of the Westminster Confession in the seventeenth century, but it was for the most part ignored by the churches, as it fully deserved to be.

1 Walker, Creeds and Platforms, pp. 567 f. 
The regular series of National Councils begins with that held in Oberlin, in $187 \mathrm{I}$, to celebrate the two hundred and fiftieth anniversary of the landing of the Pilgrim Fathers. A constitution was adopted providing for a triennial session, at which there should be discussion of matters of denominational interest, but no legislation. Judicial powers were likewise excluded from the Council's province. Plans were formulated whereby the churches and Congregational associations should be proportionately represented at the Councils, and a declaration on the unity of the church was put forth, which in substance has since been several times repeated, with irenic intent.

There have been in all sixteen sessions of the National Council, meeting until very lately at three-year intervals, but now biennially, in accordance with a revision of the constitution adopted in r9I3. The sessions have seldom been attended by much more than one-half the number of delegates entitled to be present, showing that many of the Congregational churches have not interested themselves in the cause of united denominational action. But the history of recent years indicates a growing interest in the Council, and a belief that it can wisely and safely be made to serve the common interests of the churches, which, in the absence of some such central body, might perhaps suffer. These recent developments, with the demand for increased efficiency and a more compact polity, recall the Proposals of 1705, and the provisions of the Saybrook Platform. But little objection is now raised, and little fear of too great centralization is expressed, - so accustomed are we to the existence of similar movements in our modern industrial and political life. The traditional principle of local independence for the individual church is thought to be sufficiently safeguarded, by repeated assertions of its inviolability. 
In pursuance of action taken at the Council held in St. Louis, in I880, the preparation of a new creed was undertaken by twenty-five commissioners who had been carefully selected to represent the various theological tendencies discernible among Congregationalists at the time. The result of their deliberations was the so-called Commission Creed of 1883 . It was put forth by the commissioners themselves without further endorsement, "to carry such weight of authority as the character of the Commission and the intrinsic merit of their exposition" might command. The Creed was in fact sufficiently comprehensive to suit the more progressive members of the Commission, and too much so to suit the most conservative, three of whom refused to sign it. Among the signers were President Seelye of Amherst College, Dr. Henry M. Dexter, editor of The Congregationalist, Professor George P. Fisher of Yale, Dr. William M. Taylor, pastor of the Broadway Tabernacle church of New York, Dr. Alexander McKenzie of Cambridge, and Dr. Lyman Abbott of Brooklyn. The three who refused to append their names were Dr. E. K. Alden, Professor W. S. Karr of Hartford Seminary, and Dr. E. P. Goodwin.

The new creed proved acceptable to the churches in general, and was adopted by many of them as the statement of their faith. But the rapidity with which modern protestantism has moved away from the older dogmatic thinking is shown by the fact that, at the expiration of only thirty years, the churches have thought it desirable to frame a new and still shorter creed. The Preamble to the Kansas City formula ${ }^{1}$ does indeed reaffirm the allegiance of Congregationalism to "the faith which our fathers confessed, which from age to age has found expression in the historic creeds of the church universal and of this communion," yet when one passes on to examine "the things most surely believed

1 Adopted by the National Council in I9I3, at Kansas City, Mo. 
among us," one finds them comprised in a very brief statement, about as long as the Nicene Creed, but strikingly different in character. Where that tried to be minute and precise, - and succeeded, - this tries to be general. And it succeeds. But if it has comparatively little to say of the great historic affirmations of the Christian faith, it emphatically declares the church's duty to serve the world, in full accord with the modern note of social responsibility. The creed is perhaps as good a one as could be framed at present, and it pledges all who sign it to the active exercise of Christian living, which is more than can be said of some of the doctrinal formulas of the past.

The most notable illustration of the vitality and efficiency of the loosely organized Congregationalism of one hundred years ago is to be found in the formation of the American Board of Commissioners for Foreign Missions. This remarkable organization with its world-wide interests was born and bred in New England and has its legal home in the ancient commonwealth of Massachusetts. It was New England energy, New England devotion, and New England money, that made Congregational foreign missions possible, and that without the intervention of ecclesiastical machinery. The voluntary association of like-minded men and the zealous coöperation of the theological school at Andover combined to create a great philanthropic and religious enterprise, whose influence has reached out to the farthest boundaries of the earth. The Board's missions, schools, colleges, hospitals, and institutions for manual training, now encircle the globe, and their reflex influence upon the churches at home has proved to be of the highest value. ${ }^{1}$

Other enterprises of large scope and usefulness were undertaken from time to time, as the nineteenth century pro-

1 See W. E. Strong, The Story of the American Board, Igro. 
gressed and as the work of home missions, church building, and education began to call for better organization and equipment. These denominational activities were entrusted to voluntary societies of national scope, which have fulfilled their trust with commendable devotion and success. They have recently been brought into organic connection with the National Council.

It has been said that the religious history of America falls into three periods: first, the metaphysical, covering most of the colonial era; secondly, the ethical, including the Unitarian movement; and thirdly, the aesthetic, limited to the last half-century. Whatever may be the propriety of such a division, there can be no doubt that recent years have witnessed a marked development of certain kinds of aesthetic appreciation and ambition which were lacking before. Altered forms of ecclesiastical architecture, the enrichment of public worship, and the general abandonment of Puritan simplicity, all are signs of a refinement of taste, but perhaps also of a diminished conviction of the immediate presence of God, which was such a notable trait of the early New England character. Recent sessions of the National Council have approved and issued forms of public worship, for optional use in the churches; forms for the Communion, for baptism, marriage, and the burial of the dead, for ordinations, and for the dedication of church buildings. To supply the material for all these, the Book of Common Prayer has been liberally, although not exclusively, drawn upon. Many modern Congregationalists have welcomed these changes, and have made increasing use of them; whether for good or ill, remains to be determined. It would certainly be a serious loss to our free churches if the dignity and stateliness of the older Puritan worship were to disappear. For they were the external signs of a brave and manly spirit, seeking to worship God, who is spirit, in spirit and in truth. 
The development of a stately ritual has sometimes been interpreted as a mark of decaying faith. "Religious ideas," said Lecky, "die like the sun; their last rays, possessing little heat, are expended in creating beauty." Just as, when daylight wanes, the sky above our heads takes on its transient glories, - crimson and gold, melting into the softer tints of old rose, lavender, opals, and amethyst, until darkness drops her veil over the fading twilight, and the day is done, - so the waning forces of religion, having lost their vital power of warmth, lose themselves in the fair colors of the evening sky. I would not be understood as giving to this sentiment an unqualified approval. Then were the historic worship of christendom one long expression of decadence. Yet it undeniably contains an element of truth, to which modern Congregationalists may well take heed.

Congregationalism has always proved itself productive of men qualified for leadership through their nurture in the philosophy of individualism. In this respect the nineteenth century was no exception to the rule. Without attempting anything like a complete catalogue, we may single out the names of Moses Stuart, pioneer Biblical scholar of America, who taught philological methods which have led the way for all his successors, not only in his own department of the Semitic languages but also in the classics; and Leonard Bacon, eminent as pastor and denominational leader, who with moderation and diplomatic skill guided the churches of New England through many difficult years; and Mark Hopkins, beloved president of Williams College, the foremost educator of youth of his time, to know whom was esteemed a liberal education; and Horace Bushnell, seer of visions hidden to the many, who was faithful to the spirit of the past, yet able to interpret for his fellow ministers the theology of the future; and Henry Ward Beecher, greatest pulpit orator of his generation in America, whose voice was 
never silent, nor his pen idle, in the presence of injustice and human wrong. These names stand out distinctly, yet beside them are others which offer no unworthy contrast to their fame. There are many who have deserved well of God and man. Every lover of light and progress should pray that the succession fail not in the years to come.

The New England of the twentieth century is not the New England of the Puritans, nor even that of fifty years ago. Permanent changes have come over every aspect of its life; the old social homogeneity is gone, never to return, and the institutions which gave it character have, to a large degree, gone with it. We now behold a heterogeneous industrial population, drawn from many foreign nationalities and crowded into our great cities, and an idle summer population, at seashore and in the mountains, drawn from the leisure classes far and near. Many types of religion and irreligion, undreamed of by the fathers, have taken root among us. Everywhere lie new problems for organized Christianity. Our free churches, with their elasticity and power of adaptation, should prove capable of discharging their new tasks. But to do so with success, they need a faith as strong, and a devotion as overmastering, as our fathers brought with them to these shores, when, in the fear of God and in humble reliance upon His almighty aid, they laid the foundations of a Christian state, and established churches dedicated to freedom, truth, and human brotherhood. 

THE REVOLT AGAINST THE STANDING ORDER

\author{
I. Popular Movements \\ II. The Unitarians
}

WILLIAM W. FENN 



\section{THE REVOLT AGAINST THE STANDING ORDER}

\section{POPULAR MOVEMENTS}

T $\mathrm{N}$ a recent book entitled $A$ Century's Change in Religion, 1 Dr. George Harris, honored ex-President of Amherst College, amusingly suggests that the standing order in Connecticut was so called from the Congregational habit of standing, while Episcopalians knelt, during prayer time. In similarly playful vein one might derive the term from the fixedness of the churches, standing pat, as it were, behind apparently impregnable intrenchments of creed and cult and custom, with no aspiration for advance or dread of dislodgement. In reality, however, the designation implies no more than that the Congregational churches constituted the established church, from which all others were regarded as dissenters. In their several communities each was the church of the town, serving the whole town and supported by a tax levied proportionally upon all the inhabitants.

With certain qualifications to be made hereafter, such was the situation in Massachusetts at the beginning of the last century, but already there were signs of disaffection towards this standing order. In the present lecture two of these movements of dissent, popular in character, are to be considered, namely the Free Will Baptists and the Christians, each of which traces its origin in New England to a single individual, the former to Benjamin Randall of New Hampshire, the latter to Abner Jones of Vermont. Benjamin Randall was born in Newcastle, New Hampshire, in 
I749, and was converted in I770, shortly after the death of Whitefield, and partly in consequence of feelings awakened by it. Randall's "exodus through the churches" is of interest as typical of the contemporary religious drift. $\mathrm{He}$ was brought up in the Congregational church, but his warm religious nature and, in particular, his sympathy with the preaching of Whitefield, found little satisfaction in the cold and arid type of piety then prevailing in the Congregational churches, and consequently he soon set up a private meeting for prayer in his own house, which was frowned upon by the local pastor. Similarly, at the time of the Great Awakening, those who sympathized with it found most of the churches of the standing order chilly and uncongenial and as a result became Separates, or New Lights, founding churches, some of which afterwards became Baptist. Following the same course, and convinced by his study of the Scriptures that immersion of adult believers was the only true mode of Christian baptism, Randall next joined a Baptist church. But he soon found that here was no resting place for his adventurous spirit. At this time the Baptist churches in New England were Calvinistic in theology, and Randall, who had come to see in Jesus " universal love, a universal atonement, a universal call to man, and felt confident that none could ever perish but those who refused to obey," found his eager desire to preach a free Gospel blocked by the strict Calvinistic doctrines of election and limited atonement. Nevertheless he preached, but was soon called to account by his Baptist brethren, who, if they did not actually disfellowship him, manifested such a spirit of opposition to him and the work he was doing that again he went forth out of the camp and in I780 organized a church in the town where he then lived, New Durham, New Hampshire. This, like churches already existing in Canterbury and Crown Point, was at once Arminian in doctrine, holding to free 
will, and Baptist in practice, because it maintained believers' baptism by immersion. Not until some time afterwards was the name of Free Will Baptist accepted, after the simple designation Baptist had been rubbed off by controversy and before the more comprehensive name of Free Baptist came to be generally preferred. The movement thus begun spread with amazing rapidity throughout eastern New England revealing a wide-spread popular dislike for the standing order. Its preachers going beyond New England soon fell in with groups of people who had reached substantially the same views independently - Free, or Open, Communion Baptists in western New York, Separate Baptists in Kentucky and elsewhere, some of whom, although not all, were gathered into Free Will Baptist fellowship. I say not all, for it should be remembered with praise that when in 1839 one Dr. Housley appeared before the General Conference as representative of several thousand persons in Kentucky holding Free Will Baptist sentiments and seeking fellowship, the overtures were promptly refused on the discovery that many of these sympathizers, including Dr. Housley himself, were slave-holders.

Of the honorable history of these Free Will Baptist churches in New England, I cannot speak at length. Henry Ward Beecher is reported to have said that they were always on the right side of every moral question and on the evangelical side of every controverted doctrine; and the tribute was well deserved. Although their early preachers were illiterate men, and, for reasons soon to be mentioned, there was a prejudice in the denomination against an educated ministry, some of the itinerants sought to make good their literary deficiencies by private study and, in order that their successors and the youth of the denomination might have privileges which they themselves had never enjoyed, set to work to convert the fellowship to their point of view 
by awakening an interest in education. The labor was hard and often discouraging, but successful: a book concern was established, The Morning Star was taken over, academies were set up, and Bates College was founded. Finally after a most creditable career, seeing that the Baptist churches in general had mitigated their Calvinism and were upholding substantially the same principles which they had championed from the beginning, the Free Baptists returned to the fold from which Randall and his friends had regretfully departed and as a separate denomination died in glory.

The Christians trace their origin to a certain Abner Jones who was born in Royalston, Massachusetts, in I772, but soon moved to Vermont where, in the town of Lyndon, the first Christian church in New England, and so far as he knew, in the modern world, was organized in r8or. Personally this Abner Jones does not impress one quite so favorably as Randall. He seems to have been of a roving temper, never continuing long in one stay, shifting easily from doctoring to preaching and back again, gaining local fame as a cancer doctor in possession of a secret cure, - a rather flighty spirit in contrast to Randall's solidity; nevertheless he had come upon a noble idea, even nobler perhaps than Randall's. It was that all party designations degrade the followers of Christ, who should bear and honor their Master's name alone. Although he himself was ordained by the Free Will Baptists it was with the express understanding that he would never acknowledge the name, although he would work in fellowship with them, as he would with any followers of Christ of whatever name who would work with him. Elder Jones was a versifier, writing "pomes" which all came in rhyme somehow, and one of these effusions sets forth his cardinal principle: 


\section{MY CREED}

Of all unscriptural names that are

In christian churches claimed so fair,

'Gainst them I enter my dissent;

On Christ's sole name my mind is bent.

The church of Rome and England too, Are names of men, which once were new;

The highly boasted Baptist name,

And Methodist are all the same.

The Presbyterian, polite,

And Universalist so light, The honest Quaker, thee and thou, Are merely names of men, I trow.

Disciple, follower, christian, friend, For these I equally contend!

With every other scripture sound, In Gospel rule that can be found.

Altho' these names, I do reject, Yet those who hold them I respect

As brethren in the Lord of life;

So live in love and quit all strife.

My fellowship in Christ is bound

To all those souls where love is found

Of every order, sect, and name, -

In Christ I count them all the same.

At first the relations between Christians and Free Will Baptists were close and cordial, but the two bodies gradually drew apart. Under the influence of Elias Smith, the Christians were led to appear sympathetic with Universalism, or at least with the doctrine of the annihilation of the wicked. Moreover, in their aversion to unscriptural terms, the Christians were reluctant to speak of the Trinity, for example, and were supposed to be verging towards Uni- 
tarians with whom, however, they had no commerce. Besides, their preachers, like those of the Free Will Baptists, in their journeyings over the country fell in with isolated groups who sympathized with their principles and in some cases had actually taken the name Christian to the exclusion of every other. The Christian Connexion of the West which now has its headquarters in Dayton, and the great company of the Disciples or Campbellites, some of whom call themselves simply "Christians," arose quite independently of the New England Christians, although often confused with them in the popular mind. There are still to be found hereabouts a few Christian churches, but they are few, ninety-four according to the Government Report of I906, and weak, and their affiliation is now with the Western Connexion, although in the case of such as have survived from the original New England movement the affiliation is rather tenuous.

Having referred to the travelling preachers of the Free Will Baptists and the Christians, let me here speak very briefly of them and of their biographies. Fortunately many of them were in the habit of keeping journals which found their way into print, and I know of no books richer in human interesi than these memoirs and none which throw more light upon the life of New England farming communities during the first half of the last century. The biographies, in most cases the autobiographies, of Fernald, Jones, and Elias Smith among the Christians, of Randall, Phinney, Marks, Stinchfield, Young, Colby, and Bowles among the Free Will Baptists, are a comparatively unworked mine of rich material. These were all uneducated men, not one of whom had received the equivalent of a modern high-school training, but they were of quick understanding in the fear of the Lord, and their originally large endowment of mother wit was increased by their experience with all sorts and con- 
ditions of folk on the country-side. Not for them, the formal meeting-houses with pews remote from the pulpit propped high above them at what Lowell called the natural angle of somnolence; they preached usually in school houses, barns, and private houses, where they could see the whites of their auditors' eyes and read their shifting moods of approval or dissent. So they became incomparable practical psychologists, knowing how to reach the hearts of their hearers. Being men of the people they knew how their fellows thought, and spoke the language of the field and the village store with occasional flights, or falls, into rhymes like those which disfigured the local poetry column of the country newspaper. Their nearness to the people in the meeting places was symbolic of their nearness to them in every respect. Their words went home because they had not far to go. From mind to mind half the circuit of the world may lie, but heart to heart is very near. Besides, although there were a few impostors, nobody could suspect these wandering preachers, when properly accredited, of selfish or sordid motives. Preaching was not a mere trade with them, there was no money in it. Often they would ride off on a long journey of many hundred miles with but a few cents in pocket, and return with even less than when they started. They had no stated salary; a coin pressed into the hand by a friendly listener who " didn't want to steal his preaching," and whose kindness, whether the gift were a shilling or a dollar, was often gratefully acknowledged in the Journal, enabled them to pay their tolls, and their keep when hospitality failed, but that was all. ${ }^{1}$ Why should they leave their occupations to undergo these hardships, and subject their families to even greater, unless they really felt the Lord's call to labor for the souls

1 "I had spent more than two months in Canada and travelled five hundred miles. The people generally were kind and liberal. Though among strangers and often lodging at public houses, my expenses, besides some repairs, had not amounted to fifty cents." (1827), Marks, p. I74. 
of men. So reasoned the common people, not unwisely, and their confidence followed their logic. These itinerant preachers were men of power: some, like Fernald, were gifted with physical strength, and voices which when uplifted in prayer or preaching reached the ears of sinners a mile or even two miles away with subduing and convincing power; others were of fragile frame, like John Colby, early marked for death and swaying the hearts of men like messengers from the invisible world - but all of them were men of force and their influence upon the popular religious life of New England was incalculable. The principal point, however, is that these preachers were successful because they gave articulate utterance to sentiments which were potent but unformulated in the hearts of the common people. Their homely speech revealed the thoughts of many minds. In them, therefore, we discover a protest against the standing order which had to do mainly with three points, polity, creed, and experimental religion.

With respect to polity, the objection was to certain ecclesiastical usages connected with the calling and settling of ministers, especially the holding of church councils, which were deemed unscriptural, and particularly to the practice of supporting the churches by a public tax, in which they were at one with the Baptists. The history of the lastmentioned usage must be briefly recapitulated. Before Endicott's company sailed for Salem, the New England Company contracted with Bright, Higginson, and Skelton to come over with the planters as ministers. Their salaries were to be paid one-half by the planters and one-half from the Joint Stock, afterwards changed to the Common Stock, of the Company. Immediately after the arrival of Winthrop's Company, however, provision was made for the support of Wilson and Phillips by assessment upon all the colonists save those of Salem and Mattapan, where other 
arrangements already existed. In Boston, Cotton came out strongly for voluntary support, and afterwards none of the churches in Boston was ever supported by public tax. Elsewhere, also, the voluntary system was favored, but it soon appeared that on account of unwillingness to contribute on the part of those who were not members of the church the amount raised was insufficient to maintain properly the minister, or ministers, and consequently a demand arose that since all the inhabitants of a town did, or might, enjoy the privileges of the Gospel, all should pay for its support. Both the Massachusetts Law of 1638 and the Recommendations by the Commissioners of the United Colonies in 1644 recognize the voluntary system in principle but declare that if a man refuses to contribute he may be assessed. This is the view also of the Cambridge Platform. But a law of I63I, refusing the franchise to all who were not church members, precluded all the inhabitants of a town save those who were in full communion with the church from any voice in the choice of a minister or in the management of church affairs. Therefore these outsiders were naturally averse to paying for the support of a minister in whose selection they had not been consulted, and for the maintenance of public worship from the most sacred and precious rite of which - the Lord's Supper - they were excluded. As Englishmen, they claimed the right to enjoy the Communion here as in the mother country, but this was denied them unless they should first be chosen into membership after a somewhat inquisitorial examination and the presentation of a Spiritual Relation, nor until the adoption of the Half-way Covenant were they authorized to offer their children for baptism unless at least onc parent was in full communion. But even the Half-way Covenant applied only to baptized, although non-communicating, members of the churches here, and conferred no right to the franchise. Obviously, 
therefore, their resentment would be heightened if they should be compelled to pay for the support of such a church, but this soon came to pass. By an act of 1654 , the County Courts were empowered to order the selectmen of a town to assess all its inhabitants for ministerial support. This was upon complaint laid before the Court; but later the Court was instructed to take the initiative by ordering the Grand Jury for each County " to present all abuses and neglects of this kind in order that God may continue his favorable presence." The course of legislation indicating the drift of popular opinion is reasonably plain. Theoretically the voluntary system was honored, but in practice it was found not to work satisfactorily and to be in need of supplementing by enforced assessment. When the old order ceased with the recalling of the original charter, and, with the admittance of all freeholders to the franchise without religious qualifications, one objection to the assessment principle was removed, but the principle of taxation was positively affirmed by the act of 1692 . During the provincial period this principle underlies all the legislation. But other and graver difficulties soon appeared. In the earlier days, unwillingness to contribute might sometimes be ascribed to meanness, or indifference to religion and the public welfare, but subsequently the Courts had to deal also, and increasingly, with persons who refused as a matter of conscience to pay their town assessments for religious purposes. Quakers, who disbelieved in a hireling ministry, and Baptists - Anabaptists as they were popularly called - took it ill that they were taxed against their consciences for the support of hireling, or paedo-baptist, preachers and demanded exemption. The existence of such persons is noted in an act of 1702 , but apparently no exemption was made in their favor until by pressure from England it was enacted, with certain qualifications, in behalf of the Episcopalians 
in 1727 . In the very next year, 1728 , we find a similar law exempting Quakers and Anabaptists, alleging a scruple of conscience. From this date until I833, when the principle of public taxation for the support of worship was formally abandoned, there is a long string of exemption laws which it would be tedious to rehearse. They were designed to guard against the extension of exemption to persons who claimed relief out of mere stinginess and not on the ground of conscience, but provisions of such a character always prove most irritating to the best of those who are affected by them, and so antagonism to the system was steadily on the increase. In the Constitution of 1780 the principle of assessment was again formally recognized but along with it is the provision that on application any man's tax may be paid to the minister of the church which he attends and there is also the significant sentence, "No subordination of any one sect or denomination to another shall ever be established by law." This would seem to have been sufficiently equitable, granting the fundamental principle, to silence all reasonable objections, but in practice there proved to be many grievances. Upon a Baptist for example the tax might be levied and collected, but if there were no Baptist minister resident in the town upon whose ministrations he could regularly attend, the tax might be turned in to the support of the Congregational minister. Besides, practically, the whole matter lay in the hands of the assessors, or selectmen, and if they decided unjustly it was for the party injured to sue - a long and costly process. It is not surprising then that this system of public taxation for the support of the ministry with all its abuses and grievances became a source of exasperation and resentment against the standing order. In the memoirs of Free Will Baptist and Christian preachers one finds abundant references to the dislike entertained for the system. The feeling 
which was fundamental to these protesting denominations led to unfortunate consequences, for it tended to leave the support of their ministers entirely to the good will of the people, and that could not invariably be depended upon. It was only after a severe struggle that the wiser leaders succeeded in arousing a denominational sentiment in favor of the decent and regular maintenance of the ministers.

More important, however, than the opposition to the polity of the standing order was the protest against its doctrine. Most of the itinerant preachers were of Baptist antecedents, - that is, they had come to believe that the Congregational churches were unscriptural in their views concerning baptism; but if paedo-baptism cannot stand the test of Scripture, can Calvinism? Here was the point of departure and, more specifically, the doctrine of election which was central in Calvinism. Nearly every memoir gives evidence of the effect of this doctrine upon the mind of the child who afterwards became a missionary. One may be cited as typical - from the life of Billy Hibbard, a Methodist itinerant in Berkshire County.

When this Billy Hibbard was a boy of eleven or twelve, he fell into the habit of profanity, which seemed to him source and sum of all his wickedness. One day sitting before a bright and hot open fire, it occurred to him that in such a fire he must lie to all eternity. Hence, he sought to repent for all his sins, but found so many that he feared he should not live to remember them all and repent of them sufficiently. Feeling that it was useless to pray for himself, he resolved to intercede for other sinners and while doing this he had an overwhelming religious experience. Then he fell in with a religious neighbor:

I heard him say that God had decreed all things whatsoever cometh to pass, sin not excepted, and that God had elected from before the foundation of the world all that ever would or could be saved; and 
the rest were reprobated so that they could not be saved. Of the elect, he said they might live here in sin and wickedness all their days, until a little before the breath went out of their bodies, and then God would by his special grace convert them, and take them to Heaven. Of the reprobates, he said, they might have conviction of sin, and repent and live apparently very religious lives, so that we might think them very good Christians; but God would never convert them; and though they might lead moral and seemingly religious lives until they were eighty or ninety years old it would only work out for them an aggravated damnation, for God had fixed them for it by his eternal decree, while the elect could not possibly commit a sin that could in any wise endanger their salvation. If a man committed murder many times, or hung himself, and he was only one of God's elect, he would be pardoned and taken immediately to heaven; that good works, or faith, or anything we could do was no condition of our salvation, for it was unconditional, that it all depended on the covenant of grace and this covenant of grace he represented as being wholly with the Father and the Son before the foundation of the world; that the Father then gave all the elect to his Son, if he would die for them, and the rest were left and reprobated.

With these sentiments the neighbors seemed to agree, and the minister also, hence with becoming modesty Hibbard supposed they must be true, although they horrified and dismayed him. How could he know that he was elect? He thought of a sign, but dared not venture, lest the result should be unfavorable; he undertook a jump, so long that he supposed he could not cover it without divine assistance - and then slyly shortened it, but on achieving the jump doubted whether the Lord's assistance had been needed or given; he flogged himself that he might remember to live faithful to God in the hope that so he might become of the elect, but through it all this thought disturbed his mind: "If you are elected to be saved, you will be saved; and if you are reprobated to be damned, you will be damned; and why need you pray so much ?" Finally, he came almost to the point of hanging himself, thinking that if he 
were reprobated, longer life would only add to his eternal misery.

Undoubtedly, poor little Billy Hibbard had fallen in with extreme Calvinists, and his doubts and misgivings were not wholly just, or, in their legitimate form, unanswerable, yet he was typical of many whose anxious and horrorstricken hearts were crying out against the doctrine of election. Moreover, so closely knit is the Calvinistic system that to pluck but a single thread unravels at last the entire fabric. With denial of predestination goes, logically, rejection of limited atonement. True, the Hopkinsians had introduced the moral government theory, which, in contrast with the penal theory in the form either of equivalence or satisfaction, did permit the preaching of a general atonement, but the Free Will Baptists and Christians whom we now have in view seem to have been quite unaware of this development. Living in the interior of New Hampshire and Vermont, they knew little of the Hopkinsians, and their contact was mainly with the Old Calvinism, emphasizing election, limited atonement, and the perseverance of the saints. But is this Scriptural ? How can election be reconciled with the general invitations with which the Bible abounds? With biting sarcasm, Lorenzo Dow called Calvinists "the A-L-L Part men" by which he meant that where all occurs in the Bible they read and interpret it part. As the very name implies, the Free Will Baptists preached human freedom as against divine sovereignty in predestination, and in this they and the Christians were at one. With this was associated a doctrine of universal atonement becoming efficacious for every man who sincerely believes in Christ and is regenerated by the Holy Ghost. A favorite way of putting it was that every man is elected when he believes, or, in cleverer phrase, every man is elected who votes for himself. So these itinerant preachers went 
from settlement to settlement, yes from house to house, preaching a free Gospel, proclaiming that salvation is " fully, freely, and sincerely offered to all men upon the sole condition of repentance toward God and faith in our Lord Jesus Christ."

As regards the third point: that experimental religion, by which was meant what would now be called the religion of experience, or emotional as distinguished from intellectual religion, was at low ebb in this country, as in England, during the eighteenth century can hardly be doubted. True, there was here the Great Awakening, as in England there were the Wesleyan movement and the Evangelical revival, but both here and there the Establishment was unmoved save to hostility. In this country the successors of Edwards showed much evangelistic fervor, especially under the moral government theory of the atonement, which warranted the proclamation of a free Gospel only theoretically hampered by the doctrine of election; but the rank and file of the Congregational clergy, particularly on the country-side, droned the pulpit hours away in most tedious fashion. Oft-threshed straw is poor fodder for man or beast. One who for his sins, or his students, is compelled to wade through the sermons of the period, - no, wade is not the word, for that suggests moisture, of which there is hardly a trace in the Sahara of dryness, - emerges from his wearisome task with genuine compassion for those who had to listen and could not skip save in moments when nature's sweet restorer gave temporary relief from the doctrines of grace. To use Dr. Holmes's figure, the sermons were like Passover bread, holy but heavy. The preachers were like that hapless clergyman on the snowy day in the Concord meeting-house of whom Emerson writes:

The snowstorm was real, the preacher merely spectral, and the eye felt the sad contrast in looking at him, and then out of the window 
behind him into the beautiful meteor of the snow. He had lived in vain. He had no one word intimating that he had laughed or wept, was married or in love, had been commended, or cheated, or chagrined. If he had ever lived and acted, we were none the wiser for it. The capital secret of his profession, namely, to convert life into truth, he had not learned. Not one fact in all his experience had he yet imported into his doctrine. This man had ploughed and planted and talked and bought and sold; he had read books; he had eaten and drunken; his head aches, his heart throbs; he smiles, and suffers; yet was there not a surmise, a hint, in all the discourse that he had ever lived at all. Not a line did he draw out of real history. The true preacher can be known by this, that he deals out to the people his life, - life passed through the fire of thought. But of the bad preacher, it could not be told from his sermon what age of the world he fell in; whether he had a father or a child; whether he was a freeholder or a pauper; whether he was a citizen or a countryman; or any other fact of his biography. It seemed strange that the people should come to church.

Although Emerson was writing of a Unitarian clergyman in the second quarter of the nineteenth century, his description is true to the ordinary preaching in the pulpits of the eighteenth and early nineteenth centuries throughout New England. Of course, there were radiant exceptions, but they shine out against a background of gloom. There are many obvious reasons for this, such as the diversion of interest on account of war, the example and influence of the mother country, the dread of enthusiasm accentuated by the excesses of the Great Awakening, the haunting feeling derived from Calvinistic theology of the futility of preaching save for the edification of the regenerate, - but the country folk often attributed it to the over-education of the minister. "The Lord eddicates his own preachers." It is said that of the two hundred and seventy-one Congregational preachers in Massachusetts, in 1776 , there were but three who had not received a college education, and according to rustic logic sapless preaching was the result. Doubtless some here 
present recall the "pennyrial hymns" sung years ago in neighborhood meetings - why they were called pennyrial nobody seems to know, but perhaps it was because of their homely savoriness - and with the "pennyrial hymns" went pennyroyal preaching. And the people liked it, although it had to do almost exclusively with the need and the way of salvation. Some ten years ago, I chanced to meet the Rev. Charles G. Ames on Boston Common and as we walked on together, remembering that he had begun his career as a Free Will Baptist preacher, I remarked that I had just been reading the life of an old friend of his, David Marks. Mr. Ames stopped short and stared at me as if he were gazing down an interminable vista of years - "You reading the life of David Marks! Why I set up the type of that book in the old Morning Star office in Dover! Yes," he continued, meditatively, "I remember hearing David Marks preach. There was a big crowd and he began very slowly and solemnly, 'Fifty years hence all of us will be in eternity - where?" "That Mr. Ames remembered the words is significant; probably most of those who heard them did.

The need of salvation because of the nearness of death, the certainty of judgment, and the agonies of hell, upon this the preachers dwelt with morbid insistence. It is hard for us to realize the terrible oppression of the human heart and mind under such gloomy teachings. And what is worse, even little children were forced to live in the sombre shadows. Of course they could not help being more familiar with death than children are nowadays. The large families and high mortality, the small and crowded houses which made deathbed scenes unavoidable - these tended to accustom children to the valley of the shadow. But there was more than this, more than this, for, in order to give them a realizing sense of death and doom, parents made the most of the actual 
occurrence of death and kept its certain coming before the minds even of little children. The same David Marks of whom I was speaking a moment ago gives us a typical example of this:

As early as I was susceptible of instruction and capable of reflection, the truth that all must die, and appear before God to account for their actions, was solemnly impressed on my mind. At the age of four years, a sense of death and judgment caused awful feelings to pervade my soul; particularly one day, when I was alone, amusing myself with burning the tow of flax, the dreadful agony of the wicked in hell represented in the Word of God as burning with unquenchable fire was instantly brought to mind. Looking into the flame, I thought how exceedingly dreadful even one moment would be in this fierce burning; then turning my eyes towards the heavens, I said within myself, how will my soul endure if yet in sin, at the great Judgment Day, when God shall appear and set the world on fire? Finally I concluded that I would descend into a well when that period should arrive, and going immediately to my mother, told her my resolution. $\mathrm{Ah}$, my son, said she, the water will boil and the earth will burn. Another expedient was suggested. I thought I would hew out a place of retreat in a rock and there hide myself, closing the entrance. On naming this she replied, But the rocks will melt. My sorrows increased, but on reflection I hoped ere that time should come, life might be ended and my body buried in the earth; so, telling my mother I hoped by this to escape, she said - My child your hope is vain, for the dead will awake and come out of their graves. My last expedient it now appeared would fail; and retiring to a field my anguish became great, while reflecting that my parents were Christians but I was a sinner; tears flowed profusely, and putting my hand on my bosom, I cast my eye toward heaven and said, God be merciful to me a sinner. Now existence was a burden; the burning of the tow recurred to mind, and I earnestly wished that I was something inanimate, even if it were tow, that I might not feel the vengeance that would fall upon the wicked. Once as my mother laid me down to rest, she said, Soon my son, you will exchange the bed for a grave and your clothes for a winding sheet. Often after this when I lay down at night, my bed reminded me of the grave and my sheets of the grave apparel. Serious thoughts of death and judgment continued to exercise my infant powers. 
Little wonder that when at the age of fifteen David Marks left his home to take up the life of a travelling preacher, he frequently began his sermon with the solemn repetition of three words: Death, Judgment, Eternitya practice which, in substance, as Mr. Ames was witness, continued through his life. One wishes that David Marks were an exception, but the biographies of his coadjutors in the field contradict the wish. They were blood-curdling preachers dealing out horrors with a lavish hand. Naturally their hearers got the thrills which they usually failed to get in the village meeting-house, where similar doctrine was taught but not in so pungent a way.

There was, however, in the conventicle one vast improvement upon the meeting-house - the former opened a way of escape which the latter hardly knew. What must I do to be saved? When an aroused penitent put this question to the college-trained, village minister, what was the reply? What could it be on Calvinistic premises according to which man can do absolutely nothing towards his own salvation lest his merit should detract from the fulness of God's glory? The best that could be said was that his penitent frame was evidence that God's spirit was working within him and would carry the work forward to perfection provided he were of the elect. But this must have been depressing counsel. The travelling preacher, however, was not baffled - there was something for the penitent to do, ask for prayers, come to the anxious seat, forgive your neighbor the wrong he has done you, make a complete surrender to Christ and signalize your consecration by baptism and a way of life eschewing cards, dancing, and worldly frolics in favor of sober and solemn thoughts concerning death and hell.

Naturally, the conventicles often became scenes of madness. We read of meetings lasting through the night in which men and women fell to the floor, sometimes dumb 
and rigid, sometimes writhing and shrieking in agony, of visions, and prophecies, and the like; but the more experienced of the preachers grew suspicious of such demonstrations and were disposed to discourage them. And one must never forget that notwithstanding regrettable extravagancies and the wholesale dispensation of terrors there was real life in it all, life protesting against the hard conventionality of the standing order and its hopeless Calvinism. The guerilla warfare was crude but effective. Yet, contemporaneously, there was going on a movement within the standing order of a totally different character, organized and academic, of which we shall have to speak in the next two lectures upon the Unitarians. 


\section{THE UNITARIANS}

\section{I}

IN the course of the last lecture, it was incidentally observed that Christians were suspected of dallying with the liberal party of the standing order, afterwards called Unitarians, although in fact there were no relations between them. Yet the suspicion was natural, for in some respects the two groups closely resembled each other. The Liberals studiously ignored or plumply denied the doctrine of the Trinity, and Christians fought shy of the word as unscriptural. Jones and his followers held that in some way the death of Christ availed for the forgiveness of sins, and so did most of the Liberals, yet neither party was disposed to speculate, still less to dogmatize, concerning the why and the wherefore. Both were severe against "man-made" formularies and pointed to the Bible as their sole and sufficient creed. If Christians renounced party names, the Liberals objected stoutly to a new denominational distinction and afterwards aimed to be, and boasted that they were, a non-sectarian sect. And yet with all these points of similarity, I should be exceedingly surprised to learn that either Freeman or Channing ever visited either of the halls, or, afterwards, the little chapel at the corner of Summer and Sea Streets, where the Christians worshipped, or so much as knew Abner Jones by sight.

The reasons are obvious, if not wholly creditable to the Liberals. For one thing, theirs was an academic movement and carried the Harvard stamp. Appended to John Wilson's Elegy on John Harvard, preserved in Cotton Mather's Magnalia, is a quotation from one of Arrowsmith's AntiWeigelian Orations, applied to Harvard College, which prays that it may be "so tenacious of the truth that it shall be 
easier to find a wolf in England or a snake in Ireland than a Socinian or Arminian in Cambridge," and could the particular faith of the Mathers have prevailed, the prayer would have been answered. But even while Increase Mather was nominally President of the College, his frequent absences threw its management into the hands of Leverett and Brattle, who represented a progressive tendency, and from that time on, the College developed away from the creed of its founders until it became a veritable breeding-place of Arminians and Massachusetts "Liberals." All of the ministers of the party, and many of its laymen too, were graduates of Harvard, and the College was governed by men who sat on Sunday in the pews, or stood in the pulpits, of Liberal churches. The wealth and respectability and culture of Boston were with them. The Christians, on the other hand, were obscure and humble laboring folk and their preachers carried no academic degrees. It was distinctly a popular, as Unitarianism was an aristocratic and academic movement - they were in different orbits which never intersected. Another reason is that the Christians were opposed to the standing order, while the Liberals stood inside it, fully approving. It is true that the latter were not in sympathy with the traditional theology, yet they were strong for the tradition of Congregationalism as a form of church polity, and saw no reason why Trinitarians and non-Trinitarians might not worship together in its free fellowship. They had no wish to be come-outers, and I suppose it was undoubtedly for this reason among others that they consorted not with the Christians.

What has just been said partly explains a fact which puzzles a visitor to New England, in case he be interested in religious matters, namely that many of the "First Churches" hereabouts are Unitarian. In most cases they do not bear the name save perhaps in inconspicuous letters on the sign- 
board, sometimes they call themselves simply the First Church, or even the Congregational Church, of the town, but they are Unitarian nevertheless in denominational affiliation. How has this come to pass, asks a curious visitor, that the oldest churches are homes of one of the most recent heresies? To answer this inquiry is the purpose of today's lecture.

With the exception of King's Chapel, the history of which begins in Episcopalianism, all the early Unitarian churches in New England belonged originally to the standing order and developed within it. The story of King's Chapel has been so fully and admirably told by the Rev. Henry W. Foote, a former minister, in his Amnals of King's Chapel and is so well known, that it need not concern us at present. We shall restrict ourselves therefore to the Unitarian churches which have their beginnings in ancient Congregationalism, and waive also the recondite and intricate question as to the earliest representatives of the "heresy," for indeed the growth was very gradual, continuing through two or even three generations, and the break when it occurred was one of the "critical points in the continuity of natural phenomena" - to borrow Professor Shaler's felicitous phrase. In many cases, as for example the First Church in Boston, there was no sharp break at all and the original covenant of the church, like that of many another of the earliest churches, was so broad and untheological in character - a covenant of life purpose and not a creed - that it has been retained unaltered and unabridged even to this day. In so slow a process, therefore, it is manifestly impossible to fix beginnings, and our best course is to take up the story at some definite point where the differences are clearly recognizable. To go no farther back, then, than the beginning of the last century, we find at that time three pretty distinctly marked parties in the standing order of New England. By far the largest of the three was the group of Moderate Calvinists who held 
to a vaguely mitigated Calvinism. God was sovereign, but to some extent and in some way man was somehow free and responsible. Regeneration was by an immediate act of the Spirit as the pure effect of God's free grace, but it was well for man to avail himself of the means of grace, go to church, read his Bible, and pray, yes, perhaps even attend the Communion, so that, at least, the Spirit would not have to travel far afield on his regenerating errand. Of course, here was palpable inconsistency, but the Moderates did not know it, or, if they knew it, did not care. But there was a party composing the right wing of Congregationalism who did know and care. As they rightly reasoned, What is the use of being Calvinists at all unless thorough's the word? So they, Edwards and his adherents, called themselves "Consistent Calvinists," fearlessly pushing constructive principles to their extreme logical issues. God's absolute sovereignty in election and reprobation, man's helplessness and total moral inability on account of the sin of Adam, - to these doctrines, and their logical corollaries and consequences, they consistently adhered. Two things, however, they held for which we may properly magnify them: the first was a moral government theory of the Atonement which theoretically, at least, opened to all mankind the benefits of the death of Christ while at the same time robbing Universalism, as it then was, of its most cogent plea. The second, of indefinitely greater significance, was a moral ideal of surpassing grandeur. Edwards is popularly known as the preacher of almost incredibly cruel hell-fire sermons, or, among philosophers, as author of a book on the Will which is more often praised than read, but his powerful claim upon the honorable memory of mankind lies in the surpassing moral ideal contained in his treatise "On the Nature of True Virtue." Perceiving that an act gets its moral quality from the motive that inspires it, or more accurately from the 
attitude and spirit it betokens, Edwards taught that true virtue consists only in love to Being in general, or, specifically, to God considered either as the sum of all Being or as containing within himself the largest amount of Being in the whole universe, and since no one could have this love unless born of God by the regenerating work of the Holy Spirit, it follows that no unregenerate man can have true virtue or do anything in the way of good works towards his own salvation. Before such a lofty ideal as this, how shabby and contemptible appeared the morals of the Moderates and how thoroughly consistent is the doctrine that salvation can be only of God's sovereign grace. It was this moral ideal which afterwards was pointedly expressed in the inquiry - Are you willing to be damned for the glory of God? which probed to the very depths of a man's soul. What it really meant was, whether a man did love God so supremely that supposing God had decreed he should be among those useful only in their damnation, he would rejoice even thus to show forth His glory. Of course the fallacy is that when a man had arrived at the point where he felt willing to make this ultimate sacrifice he could feel reasonably certain that it would not be required of him, but, even so, behind the question lay the most exalted moral ideal ever conceived by the mind of man. Such then were the Hopkinsians or Consistent Calvinists, logical, enthusiastic, aggressive, who composed the right wing of New England Congregationalism. Then there was the left wing, the Liberals, who also took Calvinism seriously and logically, and deliberately rejected it. Thorough's the word, on the left as on the right. In fact both wings pushed out simultaneously and each stimulated the growth of the other. This is no time or place for a statement as to how these Liberals came to their radical views: doubtless the English influence during the prerevolutionary period, proceeding from Deistic authors as well as from 
churchmen like Tillotson, was in part responsible; perhaps afterwards the French influence helped; probably the broadening effect of foreign commerce contributed; but the important fact is that there the Liberals were, on the left of Congregationalism, certainly not Calvinists, and with equal certainty quite unwilling to be called Unitarians. And this not as seeking to conceal their real opinions, - of whom or what can they have been afraid, save of a schism in the ancient order, which they did indeed honorably dread,but because in truth they were not Unitarians according to the usual connotation of that term both here and in England. In that they believed in the divine unity, they were Unitarians, but so were Jews and Mohammedans; yet, unlike most English Unitarians, they were not necessitarians, religious materialists, or Socinians, nor did they share the political opinions generally characteristic of the group. Upon this point, however, more must be said in the next lecture - at present it is sufficient to present this group of Liberals as the left wing of Congregationalism.

Such was the condition of things at the beginning of the century - there were these strongly marked differences with possibility of division, but in that event it was by no means clear where the line of cleavage would run - would the Moderates ally themselves with the Hopkinsians or the Liberals? Two events answered the question. The election of Henry Ware as Hollis Professor of Divinity in Harvard College was one, and the founding of Andover Theological Seminary was the other. The former aligned Moderates in opposition to the Liberals and the latter signalized the union of Hopkinsians and Moderates. So the line was drawn and the Liberals were on the lonely side of it. The result was that notwithstanding earnest protestations and pleas on the part of the Liberals, the old Congregational order was split asunder and the Liberals were com- 
pelled to organize for mutual fellowship and support. Inevitably there was bad feeling on both sides. It has frequently been observed that there is no rancor like that between theological opponents who fight for the glory of God as if the very devil were in them. In general, this is probably owing to the fact that religious interests are very deep, lying near the inmost springs of feeling and hence bringing out, when aroused, the essential natures of men. In a little book on Oliver Cromwell, Frederic Harrison has a keen analysis of Puritan character under Puritan theology in which he says: "It depended very much on the zealot's own nature whether the result was good or bad. A great and wise man had his greatness and his sagacity intensified, for his own soul was transfigured to himself. A man of selfreliance had his will heated to a white heat, for he knew himself to be the chosen instrument to work out the decrees of the Almighty. And so the self-sufficient man treated all who opposed him as the enemies of God. It was a form of belief which could bring out all the good and all the evil of the heart." What is here said of Puritanism is equally true of religion in general, when living and momentous. The zealot identifies his cause with the divine will and so becomes resolute and relentless, counting his opponents wickedly hostile to God and hating them accordingly. Consequently, notwithstanding the high character of the men involved in this New England controversy, the very fact that it concerned religion, which was on both sides a deep and commanding interest, elicited powerful feelings which were often unjust and uncharitable and hence of course unchristian. Besides, there were exacerbating elements in the situation which sharpened general, into keenly personal, feeling.

While the election of a Hollis Professor of Divinity in Harvard College was pending, Professor Eliphalet Pearson, 
then acting President of the College, stoutly maintained in the Corporation, as the Rev. Jedidiah Morse, a graduate of Yale, and minister of the First Church of Charlestown, did in the Board of Overseers, that the terms of the Hollis endowment required that the incumbent should be a Calvinist. Into the merits of the contention it is not for us to enter. Suffice it to say, that the opinion did not prevail in the governing boards, and Henry Ware of Hingham, one of the Liberals, was elected. Shortly afterwards, in May, I806, Dr. Webber was chosen president. Whereupon Professor Pearson, an opposing candidate, resigned his professorship, and shortly afterwards withdrew to Andover, where he took the lead in founding Andover Theological Seminary. Dr. Morse, who had been the foremost opponent of Dr. Ware in the Board of Overseers, seems to have been rather credulous and suspicious, with perhaps a trace of what in anybody but a minister might be called cantankerousness in his disposition. Unhappily he became involved in a literary squabble of almost incredible pettiness, which, however, greatly embittered him. There was in Boston a certain Hannah Adams, a literary lady of very local and temporary renown, who published in I 799, a History of New England, which she proposed afterwards to abridge and publish in less expensive form. Before she could do this, however, Dr. Morse and Dr. Parish brought out a Compendious History of New England, which was briefer and less expensive than Miss Adams's original history, and was regarded as an attempt to forestall the market for her intended abridgement. In addition, there were vague accusations that her earlier work had been improperly used, plagiarized in fact, by the reverend authors of the Compendious History. As it happened Miss Adams had many friends among the Liberals of Boston who took up her cause, and for ten years a tempest raged in the tea-pot. All this is of no importance 
now save for the effect it produced upon Dr. Morse. He believed, doubtless with perfect sincerity, that the whole controversy had as its efficient cause a desire on the part of the Liberals to punish him for the decided stand which he had felt himself bound to take " against (to quote his own words) that powerful and overbearing influence which was exerted in effecting the election of the Rev. Dr. Ware to his present office, and which has operated since in completing an important revolution in the religious character of that ancient and venerable institution." It matters not whether this view was correct or not, certainly he entertained it as a settled conviction, and its effect upon his feeling depended upon his belief of the fact rather than upon the fact itself. Dr. Morse must have been uncomfortable in Charlestown, a Yale man not theologically sympathetic with the neighboring Harvard ministers, and deeply distressed by the signs of theological change which he saw all around him - and then this attack upon his reputation which he believed to be inspired by theological animosity - what wonder if he lost his head and let bitterness into his heart!

But whatever may have been the part taken by personal feeling in the case of Pearson and Morse, the mass of the clergy and laity were little affected by such trivial matters. And there was abundant occasion for profounder feeling. Harvard College was founded to provide a supply of learned ministers for the churches, and for a century and a half it had admirably discharged that function. But it appeared that the College which had held the loyalty of all, to the funds of which pious souls had contributed, some out of their sufficiency, others out of penury, had fallen into the hands of a party who were determined to make it a training school of ministers out of harmony with the theological past and doctrines dear to the heart of the contemporary religious life of New England. So religious feeling was outraged and 
bad blood was stirred up. Epithets were bandied back and forth. The Liberals no more liked to be called infidels than their opponents would have liked to be called fools. Neither side had a monopoly of piety or intelligence. Of course it was cruelly unjust to brand high-minded conscientious men, such as composed the Liberal party, both clergymen and laymen, with deceit, evasion, and hypocrisy, and resentment was natural on both sides. To call bad names always stirs up bad blood. Epithets are the epitaphs of good will. But the ill feeling was increased and consolidated by a most unfortunate event with far-reaching consequences - I refer, of course, to the controversy which found its legal settlement in the famous Dedham Case.

For a correct understanding of this crucial point it is necessary to recall the history of the relations between the church on the one hand and the town, precinct, or society on the other with respect to the settling of ministers. In colonial times, the church alone was authorized to call and settle a minister with no reference whatever to the other inhabitants of the town, all of whom, however, were liable to taxation for the support of a clergyman in whose selection they had had no voice. Of course, since church members alone possessed the franchise, others had no right to vote in any of the affairs of the town and were expressly forbidden by colonial law to meddle with ecclesiastical matters. At the beginning of the provincial period, after the religious qualification for voting had been abolished, a law was passed conferring the right of election upon the town, but this was promptly changed, and by the law of 1693 , it was provided that the church should elect the minister and, when its choice should be concurred in by the town, the whole town should become liable for his support. But suppose the town should not concur? This was provided for by the law of I695, which decreed that in case of such disagreement the church 
should call a council: if its decision were favorable to the church, the town must acquiesce; if unfavorable, the church must proceed to a new selection. Under this law, the practice became general, although not universal, of electing a minister by concurrent vote, the church taking the lead, although occasionally by agreement the church and the town, or parish, voted together. In the Bill of Rights, however, it was enacted that "the several towns, parishes, precincts, and other bodies politic, or religious societies, shall, at all times, have the exclusive right of electing their public teachers and of contracting with them for their support and maintenance." By the Law of I799, the churches were confirmed in their accustomed privileges respecting divine worship, church order, and discipline, but apparently this provision did not include the choice of minister, which remains where it was left by the Constitution in the hands of the town or society. This was a most extraordinary provision, for it exactly reversed the colonial principle and allowed the church as such no rights whatsoever in the selection of a minister. It has been suggested by high authority that the phrasing was influenced by the practice of Brattle Street Church, where many of the most prominent legislators worshipped, which had long been accustomed to the calling of a minister by church and parish acting together as one. However this may be, it may well be doubted whether the full import of the law was apprehended by either its framers or the people who adopted it. In fact, examination of the law in connection with earlier enactments, and the provisions empowering the Legislature to require the towns to provide Gospel privileges and to enjoin the inhabitants to attend public worship, suggests that the article in question was intended to preclude the Legislature from imposing a minister of its own choice upon the town (as had been possible under earlier laws) so that the phrase exclusive right 
was intended to exclude the Legislature. However that may be, there the law stood subject to interpretation by the courts should occasion arise.

And occasion did arise. It became necessary for the First Parish and Church in Dedham to procure a new minister. The society elected Mr. Lamson, whose sympathies were with the Liberals, but for that very reason the church was opposed. Nevertheless the society, with the advice and consent of a council, proceeded to ordain Mr. Lamson as minister of the church and parish. Whereupon the majority of the church seceded, among them the deacons in whose custody was certain property belonging to the First Church. I say the majority of the church seceded, because that was admitted in the trial as a matter of fact, although Dr. Lamson emphatically affirmed that the concession was made only in order to secure a decision on first principles and that in reality it was a minority of the church which withdrew. Such of the members of the church as retained their connection with the parish appointed new deacons, who sued their predecessors, still claiming to be deacons of the First Church in Dedham, to recover the property belonging to the church. So the case came before the courts and was decided by an opinion rendered at the October term (I820) of the Supreme Court by Chief Justice Parker. In brief, the opinion was as follows. The property of the church vests in the deacons of the church to be used for the support of public worship in the town or parish to which the church belongs whereof they are deacons. The church, being an unincorporated organization and incapable of existing apart from a society, must be identified by its connection with a parish. Hence, the First Church of a town is the church which is in connection with the First Parish. The Court even went so far as to hold that " as to all civil purposes, the secession of a whole church from the parish would be 
the extinction of the church, and it is competent to the members of the parish to institute a new church or to engraft one upon the old stock if any of it should remain, and this new church would succeed to all the rights of the old in relation to the parish." Furthermore, the Court held that in conformity with the provision of the Constitution the society was wholly within its rights in calling and settling $\mathrm{Mr}$. Lamson without regard to the protest of the church, which had no rights in the premises. Thus, the decision of the Supreme Court was wholly in favor of the Liberals and by virtue of it in all cases where church and society disagreed in the choice of a minister, and the former or any portion thereof withdrew, the meeting-house and all the endowments of the church remained with the church in connection with the original parish. Hence it is that many of the First Churches in New England are now in Unitarian fellowship.

To say that this decision provoked a storm of indignant protest from the Conservative party would be putting the case quite too mildly. But its worst effect was to bring the bad blood, already stirred, to the boiling point of wrath. The Unitarians who fell heir to the property of the ancient churches were accused of robbery and plunder. As a boy in one of the Congregational churches in Boston I used to hear, although not from the pulpit, that " the Unitarians stole our churches" and it was not until many years afterward that I learned that the " robbery" was by order of the Supreme Court of the Commonwealth.

Even at this late day, it takes but little to fan the embers of outraged feeling into a hot flame of resentment, but perhaps a word may be permitted from one who stands far enough removed in time from the controversy to have none of the original feeling, and whose early prejudices were wholly with the conservative side, as to the way in which the old dispute appears to one, at least, of the present genera- 
tion. That the decision of the Supreme Court was legally sound must be assumed. It would be presumptuous for a layman, whether Unitarian or Orthodox, to question it. And indeed the Constitution was perfectly explicit in vesting the society alone with the right to elect a minister. But the law had not changed the usage, which continued to be as it had been for more than a century, that the church took the lead in electing, leaving the parish or society to concur if it saw fit. The practice and the law therefore did not agree, but, as the Court pointed out, legal questions must be decided by the law and not by custom. But it was precisely that conflict between law and custom which added bitterness to the controversy. Should a church of God's elect have its minister appointed for it by a society of technical "reprobates," in whom the Spirit of God was not and who had no living connection with the great Head of the Church? Such a view was monstrous in the eyes of piety. No wonder that feeling ran hot and high. And let me frankly say that this seems to me just one of the cases where it is necessary to distinguish clearly between law and justice. A distinguished Chicago lawyer once remarked to me that the courts are not an agency for the establishment of ideal justice, but are simply part of the police system of the state for the settling of disputes. Law and Justice are not necessarily identical. Of course, ideally they should be, and in fact, ordinarily, substantial justice is reached on legal principles, but frequently, in practice, cases arise where the distinction is indispensable if one would honor his sense of justice on the one hand and retain his respect for the law on the other. The highest sense of justice in a community is often in advance of legislation. That the decision of the Supreme Court was in harmony with the law, as the law then was, must be conceded. No one familiar with the reputation and character of the Supreme Court of Massachusetts 
can for a moment suppose that its decision was affected by the theological predilections of its members, whatever they may have been. But one may grant this and yet, with all respect to the Court, be permitted to affirm that its decision does not seem equitable, particularly in view of the practice which had prevailed here in New England, both before and after the adoption of the Constitution. Yet, one may ask, would it not have been decent and honorable, notwithstanding the decision, for those whom it favored to make fair division of the property thus put into their hands and share proportionally with the seceders? Yes, that would have been just, and in Dedham if the seceders from the parish who held the property had made such a proposition (so far as I can ascertain there is no evidence that they did), the Unitarians would probably have been willing to accept the compromise and the case would have been kept out of the courts; but, since the funds were trust funds, after the Court had decided as to their proper trustees, would it then have been lawful to put them, or any portion of them, into the hands of those who according to the Court were not their legal custodians? The bitter misfortune through all this painful controversy is that the case was permitted to go to the courts at all, but when it actually came before the Court it of course had to be settled in accordance with law. And one can but admire the splendid loyalty to conscience which inspired the conservatives to depart from an organization which they deemed hostile to the Christian faith and accept the clearly foreseen consequences entailed by the separation. They were willing, be it said to their glory, to forfeit the accumulations of years, to labor and sacrifice in the upbuilding of new churches which should perpetuate the ancient creed. The law was against them, but a zeal for the truth as they saw it led to spiritual results far exceeding their material loss. 
By 1825 , then, the Unitarians were well established in Boston and eastern New England, with some churches in the interior of Massachusetts which looked to Harvard College for their ministers. But on the whole the back country was untouched by this Unitarian movement: for their ministers, the churches had, as a rule, Moderate Calvinists who were now definitely arrayed against the Unitarians. But at this very time, currents of population were setting towards the cities, the most energetic and enterprising young men and women from the country towns began to stream into Boston. What followed may be told best in the words of Theodore Parker, who a few months before his death wrote thus:

No sect had ever a finer opportunity than the Unitarians to advance the religious development of a people. But they let it slide, and now they must slide with it. In I 838 the Unitarians were the controlling party in Boston: the railroads were just getting opened and it was plain the Protestant population of the town would soon double. Young men with no fortune but their character would come in from the country and settle and grow rich; the Unitarians ought to have welcomed such to their churches; to have provided helps for them and secured them to the Unitarian fold. Common policy would suggest that course not less than a refined humanity. But they did no such thing: they loved pecunia pecuniata, not pecunia pecunians. They were aristocrats and exclusive in their tastes, not democratic and inclusive. So they shoved off these young country fellows, and now rejoice in their very respectable but very little congregations. The South of Boston is not in the Unitarian churches. A church of old men goes to its grave, one of young men goes to its work.

In the main Theodore Parker was right. The newcomers into the city brought with them for the most part prejudices against the Unitarians implanted in their home churches on the countryside, and there was no attempt to remove those prejudices and welcome them to the Unitarian churches. Even those who came from Unitarian homes in the back 
country found their warmest welcome here in orthodox churches. One speculates sometimes what would have happened, for example, if Dwight L. Moody, coming from a Unitarian home and church in Northfield, had been received into one of the Unitarian churches of Boston as he was into Mount Vernon Church, although his reception even there cannot be called exactly cordial. May a Boston boy bear witness to the fact that in the seventies neither he nor any of the common people among whom he lived would have presumed to enter this building (King's Chapel) at the time of worship, any more than he would have had the impudence to enter, unbidden, a private residence on Beacon Street. I do not say that this feeling was just: I do aver that it existed as an inheritance from an earlier time. And the fact is that on the whole young men and women coming from the country found their religious homes elsewhere than among the Unitarians. And so appears a striking anomaly. The Unitarians were liberal in theology but conservative in wellnigh everything else. The orthodox churches were filling up with young men who were conservative in theology but progressive in almost everything else. That does not put the case quite fairly for, theologically, the Unitarians, while liberal, were not progressive. They believed that they had returned to the oldest and purest form of Christianity, so that in a very real sense they held themselves to be, theologically, the true conservatives. They believed stoutly in divine revelation, especially through Christ, but also in the New Testament, and indeed in the Bible as a whole when correctly interpreted; they had no notion of progress beyond what was written, especially in the words of Christ. The Unitarians were the cult of the arrived, but in orthodox churches filled with vigorous, ambitious, progressive youth from the countryside there was the worship of pilgrims. 
Into the further history of the Unitarians, externally considered, I do not care now to enter. In addition to what has been said, it should be observed that the material progress of their churches was hindered by other causes. They were Congregationalists to the core with an almost morbid dread of ecclesiastical domination which might interfere with individual liberty, hence there was a deeply rooted prejudice against organization and central control even of the most elementary and indispensable kind, which has persisted even to this day and has undoubtedly hampered their efficiency. Furthermore, this same respect for individual freedom has given them also a prejudice against what is called proselyting, which has extended to missionary work, home as well as foreign, and to the religious education of their young people. This has given rise to queer misunderstandings. It has been said, for example, that the Unitarians have no confidence in their own religion, else they would be more active in its propagation, since one who knows he has a good thing is always prompt to push it. In reality, however, the argument should run in precisely the opposite direction: it was the very confidence in their own religious convictions which encouraged the Unitarians to believe that they would make their way by their own reasonableness, and this because they trusted so fully the inherent reasonableness of mankind. They themselves had been led, very gradually, to their position and they believed that all men were under similar guidance and therefore would come to it eventually of their own motion. Meanwhile, why should they force the educative process? This was oddly analogous to the Calvinistic view against which they were vehemently protesting, but they were unconscious of the fact, and their attitude of religious inactivity appeared to them as the logical outcome of their fundamental faith in the dignity of man as a reasonabie being. That they have taken 
but little interest in foreign missions is undoubtedly true, but it must be remembered that until very recent times the motives appealed to for foreign missionary interest and the methods employed in the prosecution of the work could not commend themselves to Unitarians. They did not believe that the heathen world was tumbling into hell over the Niagara of death. On the contrary, they believed that God in his fatherly mercy was guiding all his children and that through other faiths and forms than the Christian he was bringing them to himself. Hence, they could not in consistency with their deepest convictions participate in foreign missionary work as it was conducted until very recently. They would have sympathized, for example, much more cordially with Cyrus Hamlin's work than did the American Board. Nor has their home missionary work been particularly extensive or effective for somewhat the same reason. To be sure, after the Civil War came a period of organization in which some of the old prejudices and fears have disappeared. But the progress of Unitarianism during the last seventy-five years has been theological rather than material, and of this I propose to speak in the next lecture.

\section{II}

IN the last lecture, while using, as I frequently did, the terms "Liberal " and "Liberal Christian" to designate the left wing of the standing order I was painfully reminded of the feeling which once came over me on reading in a Chicago newspaper an advertisement of a convention of "Liberal Physicians" to be held in one of the smaller cities of Illinois. There was no subsequent account of the proceedings by which one could ascertain the principles and methods of the organization, nor were there illustrations to show what manner of men the delegates were. Unfortunately, the latter omission left a reader's fancy free to conjure up a picture of 
the company - glib and pretentious "Smart Alecks" dispersed among pompous white-whiskered "old doctors" wearing frock coats and white ties, all blatantly declaiming against the "regulars" of whatever school. It was not an agreeable picture, and very likely it was wholly unfair, yet it inspired a strong and enduring dislike for the word in ecclesiastical usage. If the designation means open-minded, free from prejudice, equally ready to discard the false, notwithstanding its antiquity, or to accept the true despite its novelty, then indeed the appellation is honorable: but by the same token it is impudent to make of it a party name as if all others than those bearing the label were besotted with prejudice, stupid and ignorant conformists in thought and practice. A similar objection was expressed by Channing, who in a letter to Thacher, under date of June 20 , I8I5, wrote as follows:

I have used the phrase or denomination Liberal Christians because it is used by the Reviewer [in the Panoplist, of Dr. Morse's American Unitarianism] to distinguish those whom he assails. I have never been inclined to claim this appellation for myself or my friends, because as the word liberality expresses the noblest qualities of the human mind, - freedom from local prejudices and narrow feelings, the enlargement of the views and affections, - I have thought that the assumption of it would savor of that spirit which has attempted to limit the words orthodox and evangelical to a particular body of Christians. As the appellation, however, cannot well be avoided, I will state the meaning which I attach to it.

By a Liberal Christian, then, I understand one who is disposed to receive as his brethren in Christ all who in the judgment of charity, sincerely profess to receive Jesus Christ as their Lord and Master. He rejects all tests and standards of Christian faith and of Christian character, but the word of Jesus Christ and of his inspired apostles. He thinks it an act of disloyalty to his Master to introduce into the Church creeds of fallible men as bonds of union or terms of Christian fellowship. He calls himself by no name derived from human leaders, disclaims all exclusive connection with any sect or party, professes 
himself a member of the Church Universal on earth and in heaven, and cheerfully extends the hand of brotherhood to every man of every name who discovers the spirit of Jesus Christ.

According to this view of Liberal Christian, they cannot be called a party. They are distinguished only by refusing to separate themselves in any form or degree from the great body of Christ. They are scattered, too, through all classes of Christians. I have known Trinitarians and Calvinists who justly deserve the name of Liberal, who regard with affection all who appear to follow Jesus Christ in temper and life, however they may differ on the common points of theological controversy. To this class of Christians, which is scattered over the earth, and which I trust has never been extinct in any age, I profess and desire to belong. God send them prosperity! - In this part of the country Liberal Christians, as they have been above described, are generally though by no means universally, Unitarians in the proper sense of that word.

I have given this long quotation because it shows the spirit which animated Channing and his friends in the distressing days just preceding the pitiable schism in Congregationalism. And from Channing that spirit never departed, as many well-known utterances at successive stages of his career abundantly prove. He was "always young for liberty" and was acknowledged by Theodore Parker as leader of the progressive party in Unitarianism, a fact of which excellent people who used to call themselves Channing Unitarians seemed quite unaware, but it was only natural that in the thick of the controversy when mean accusations were rife and ugly epithets were flying, and hitting, many of his followers should have failed to show their leader's generous and progressive spirit. And it must also be said that notwithstanding this genial and genuine irenic temper, which alone they would have the term Liberal connote, the members of the group did hold to opinions decidedly different from those of their opponents, of which they were equally tenacious, and from which, in general, they had no notion of departing by way either of retreat or advance. 
To describe these opinions and to show the historical development which did ensue within the denomination as a whole, notwithstanding the Unitarian orthodoxy deprecated by Channing, is our task today.

At bottom, both Liberals and Conservatives were agreed in accepting a revelation from God to a sinning and erring world: on the one side, this revelation was generally received without inquiry, traditionally and as of course, while on the other it was rationally upheld by the twofold argument from miracles and prophecy, the Jachin and Boaz of the temple of revelation. Both parties, then, believed in special revelation, divinely communicated, and both held that this revelation was in the Bible. The Unitarians were more ready than their opponents to acknowledge progress in the revelation, esteeming the New Testament of higher value than the Old and the teachings of Jesus as highest of all - but this difference was practically observed rather than theoretically avowed. Moreover, they preferred to speak of the Bible as the record of a revelation rather than as the revelation itself, but this too was a distinction instinctively felt and practically effective oftener than formally acknowledged. In the Christian Examiner for July, I8zo, is a flat-footed declaration of the Unitarian view:

We lay our hand strongly then upon the foundation - the Bible. We say, There is a communication from heaven. There is light supernaturally communicated, and attested, to those Heavencommissioned prophets and apostles, who, in their turn, have simply, naturally, each after the manner of his own age, his own style, his own peculiar habits of thought and feeling, imparted it to us. There are truths recorded, beyond the human reach of the men who delivered them, and they are truths dearer to us than life. Right or wrong in our conviction, this is what we believe.

Avowing thus, like their opponents, belief in the Bible and in revelation, the Unitarians went on to say that in order to 
apprehend the revelation the Bible must be rationally interpreted. The tendency of the other party was to teach that the Scriptures must be literally believed whether their teachings were rational or not, but the Unitarians were as confident as the Schoolmen that Reason and Revelation speak with one voice since God is author of both. May I digress for a moment to say that at this point both parties were wrong and that, as we have now come to see, the historical principle of interpretation must be employed. The Bible can be interpreted rationally only in case it was all written rationally and with a reason in the writer like that in the interpreter, but both of these implicit assumptions are untenable. To assume in advance that everything in the Bible must be rational, as we conceive the rational, leads almost inevitably to cruel rackings of the text and to ingeniously false exegesis. The Unitarians then were wrong in their fundamental principle of interpretation, although granting the common premise of revelation they were more nearly right than their critics, not only because revelation is not revelation until appropriated within a context of thought, but also because they had at least an inkling of the historical method, for the writer just quoted referred to individual peculiarities of style and the very form and pressure of the age as affecting the mode in which the divine message was imparted. That is to say, the eternal truth has to be enucleated from its historical form, and for this undertaking the historical method is indispensable.

What then did the Bible rationally interpreted teach? The Unitarians differed from the Orthodox at four main points. (I) They believed that the Scriptures teach the strict and simple unity and not the trinity of God. That the doctrine of the trinity was irrational, not one of them doubted, and this, indeed, was admitted on the other side, yet with the important difference that it was held to be beyond, not 
contrary to, reason, and as part of the revelation to be accepted by faith. But the Unitarians denied that it was part of the revelation, holding that the Bible teaches consistently throughout that God is one. It must be remembered, for a correct understanding of this phase of the discussion, that in New England, at that time, the doctrine of the trinity, always swaying between tritheism and Sabellianism, had swung pretty far over to the tritheistic side and the threeness was made far more prominent than the oneness of God. The Unitarian protest can be fairly judged only with reference to the contemporary views against which it was directed. In reality, the historic creeds of the Christian Church are scrupulous to safeguard both the identity and the distinctions of the Godhead, so that, theoretically, Trinitarians are no less strenuous for the unity of God than Unitarians. But, unfortunately, nobody in New England at the beginning of the last century seems to have understood the historical significance of the Catholic creeds, nor had the modern philosophical interpretation of the trinity as denoting the essential and eternal principle of diversity in unity appeared above the horizon. At the time, trinity meant baldly three persons in the plain, prosaic Boston sense of the term persons, subsisting in the one Being of a personal God similarly understood, and to the Unitarians that seemed both irrational and unscriptural; hence, they supposed it necessary to deny the trinity, in order to affirm the unity, of God.

(2) If now the strict and simple unity of God is maintained, what about Christ? This brings us to the second point of difference, the nature of Christ, and here one cannot do better than quote again from Channing's letter to Thacher:

The word Unitarianism as denoting opposition to Trinitarianism undoubtedly expresses the character of a considerable part of the ministers of this town and its vicinity and the Commonwealth. But 
we both of us know that their Unitarianism is of a very different kind from that of Mr. Belsham. We agreed in our late conference, that a majority of our brethren believe that Jesus Christ is more than man, that he existed before the world, that he literally came from heaven to save our race, that he sustains other offices than those of a teacher and witness to the truth, and that he still acts for our benefit and is our intercessor with the Father. This we agreed to be the prevalent sentiment of our brethren. There is another class of Liberal Christians who whilst they reject the distinction of three persons in one God are yet unable to pass a definite judgment on the various systems which prevail as to the nature and rank of Jesus Christ. They are met by difficulties on every side, and generally rest in the conclusion that He whom God has appointed to be our Saviour must be precisely adapted to His work, and that acceptable faith consists in regarding and following Him as our Lord, Teacher, and Saviour, without deciding on his nature or rank in the universe. There is another class who believe the simple humanity of Jesus Christ: but these form a small proportion of the great body of Unitarians in this part of our country, and I doubt whether of these one individual can be found who could conscientiously subscribe to Mr. Belsham's creed as given in the Review.

With respect to the nature of Christ, then, the majority of the Unitarians of Channing's time were probably Arians, although there were a few Socinians among them. But all of them laid stress upon the humanity of Christ, which, although the Church had labored hard to maintain it equally with his divinity, had actually faded into the background of the mind of New England Protestantism, and indeed, of Christians as a whole, if it had not actually vanished. Here the Unitarians were rendering greater service than they realized, for they were recalling to the mind of Christendom the man Jesus, fixing attention upon his character and example, and this, let me repeat, was a service which might have been, and indeed has been, gratefully accepted and acknowledged by many who are still at one with the ancient creeds in affirming both his full humanity and his full divinity. 
As regards the nature of Christ, as well as the unity of God, there was ample room in the historic creeds of the church for the affirmations of the Unitarians as well as for those of their opponents - but neither party was historical in knowledge, still less in mental temper and attitude. Nor does either seem to have had the faintest conception of the meaning of Catholic. Both equated it with Roman Catholic, and thought only of priests and the Pope, Guy Fawkes and St. Bartholomew's Eve. Whether the Catholic creeds are really credible, whether opposite statements can be brought into intelligible unity by mere juxtaposition and shrewd distribution of emphasis, is quite another matter and does not concern us here. My present point is that so far as mere statement goes there was room in the comprehensive creeds of the Catholic church for the fundamental doctrines of both sides - but neither party knew it.

(3) The third point in dispute has to do with the nature of man. It must be remembered that one feature of Edwards's movement was an exaggerated emphasis upon the Augustine-Calvin doctrine of human depravity. It was held that on account of the sin of Adam all his posterity had come under the curse of God as sinners, deprived of the supernatural endowments which their first ancestor had lost by his transgression and so depraved in nature as to be incapable, unaided by divine grace, of doing anything good in God's sight. To this doctrine of the depravity of man the Unitarians opposed their teaching of the native dignity of man. Not that they held formally to a doctrine of Creationism as against Traducianism, teaching that human souls come fresh and pure out of the being of God dowered with original righteousness - they did not carry their idea so far as that, for they were not quite so "innocent" as they have been represented. Moreover, Edwards had shown that Creationism could be quite compatible with the doctrine of 
depravity. But they did believe that in man, particularly in his reason and conscience, were divine elements unimpaired by the traditional fall of Adam, and that if by cultivation these elements became preëminent and controlling, as they certainly might, man would be good even in the sight of God. There is a standing gibe that one who was born in Boston has no need to be born again. The Unitarians held that regeneration was not needed to implant in man divine elements which, just because he was a man were in him naturally and originally. Furthermore, they believed that most of the evils from which society suffered were due to this low opinion of man, which induced those in power to treat him as if he actually were what Calvinism believed him to be, and that with true appreciation of the inherent and inalienable dignity and worth of man cruelty and oppression would cease. Thus to honor man carried with it respect for his reason and moral sense and the obligation to educate his intelligence. If the Unitarians have been distinguished for their interest in educational and philanthropic movements, it is due largely to this firmly-held conviction as to the worth and the dignity of the individual man as child of God, made in his image and retaining divine qualities notwithstanding his ignorance, weakness, and sin. As for the complicity of the whole race in Adam's sin, that was denied as both irrational and unscriptural.

(4) With the view as to the nature of man, goes a doctrine concerning salvation. Of course, if man is wholly destitute of divine qualities they can become his only through communication from God himself, and thus the doctrine of regeneration may be made to appear necessary. If, on the other hand, the divine is already in him, even in the most degraded and depraved, needing only to be awakened and emancipated, then the idea of regeneration becomes superfluous. Long before, during the century between Anne 
Hutchinson and Jonathan Edwards, the doctrine of regeneration, although still formally avowed, had fallen into abeyance. The dread of immediate revelation by the direct operation of the Spirit, enthusiasm as it was called, engendered by the Hutchinson troubles and strengthened by the Quakers, led naturally to the neglect of the idea that the Spirit acts directly in the work of regeneration and to emphasis upon the means of grace. Continuing, and more definitely avowing, this theological tendency, the Unitarians held that God ever takes sides with the human reason and conscience, aiding every good endeavor, guiding every upward aim, upon whom, therefore, man may confidently rely while he strives to walk in the way of righteousness. To apprehend adequately the significance of this doctrine one must set it against the dark background of the prevailing New England dogma, but for this we have no time today. Suffice it to say that the whole scheme of salvation as then commonly held appeared to them unworthy of God. They were unable to believe that an innocent person could justly receive punishment due to the real offender, or that righteousness on the one hand, guilt on the other, could justly be transferred or imputed. Imputed righteousness was in their eyes but a sham and a make-believe. For the real thing they supremely cared and they were daring enough to believe that God did too. Nor were they dismayed by a sense of the awful holiness of Him in whose sight the very heavens are unclean, before whom human goodness can but lay its hand upon its mouth in abject humility, for "He knoweth our frame, $\mathrm{He}$ remembereth that we are dust." Let me add that this gave rise to a comparatively new type of piety in Christianity. Through the Middle Ages the ideal of piety could be fully realized only in the separated life of the professionally " religious." Luther would have no double standard, one for the monk, another for the layman, but applied the idea 
of the religious life to the ways of common folk. This developed into the type of piety characteristic of New England Unitarians. It was reverent and devout, a piety of the understanding and the will far more than of the emotions, calling for strict and honorable fidelity in all the relations and to all the obligations of life, but lacking in the glow and fervor of feeling. There was about it a square-toed solidity and integrity - sixteen ounces to a pound and one hundred cents to a dollar, - which commands respect but fails to kindle the imagination. This was the ideal of piety arising naturally out of Unitarian thought, about which much more might be said to advantage if time allowed.

Around these four points, then, the controversy raged, but the difference was deeper than these - a difference of spirit and attitude. "These men are of another spirit than we," said Luther of the Zwinglians, and rightly. Dr. Hedge used to say that instead of Unitarianism the movement we are considering should have been called Humanism - and in truth it was at heart a human protest against a lop-sided doctrine of divine sovereignty which robbed man of all real freedom and worth. I would emphasize this, because without it the subsequent course of thought cannot be rightly understood. Man is God's child, made in His image and object of His love; his reason and conscience are divine witnesses to truth and right, and when governed by them he walks in the ways of God, safe in his Father's love and care. The God in whom their opponents believed-a God of election and reprobation, capable of dooming an entire race because its ancestors disobeyed, a God of arbitrary will and discriminating grace - seemed to them simply an immoral being and they frankly said so. But this condemnation was in the light of reason and moral sense which to the orthodox were but wandering fires compared with the clear shining of revelation as they understood it. 
So the lines were drawn. The Congregational order was divided and the two parties went their respective ways. It is for us now to follow the course of the Unitarian theology.

Do reason and the Bible really speak with the same voice, and if they appear to disagree which is to be followed? This was obviously a fundamental question certain to arise as thought and time went on. Channing said: "If after a deliberate and impartial use of our best faculties a professed revelation seems to us plainly to disagree with itself or clash with great principles which we cannot question, we ought not to hesitate in withholding from it our belief. I am surer that my rational nature is from God than that any book is." So Channing: but on the other hand Parker reports that in the Harvard Divinity School he was taught by Professor Henry Ware, Jr., that if there appeared to be any contradiction between the reason of man and the letter of the Bible, Christians must follow the written word, for "you can never be so certain of the correctness of what takes place in your own mind as of what is written in the Bible."

Here, then, were the opposite tendencies within Unitarianism, and of the two Channing's ultimately prevailed. Its victory was due not to Channing's influence so much as to the progress of knowledge in many directions. Biblical criticism undermined the argument for revelation resting on prophecy, and scientific study did the like, more slowly, for the argument based on miracles. Enlarging acquaintance with other religions made more than doubtful the supposed uniqueness of Bible teaching and so became adverse to belief in particular revelation. At last Theodore Parker appeared boldly denying the final authority of the Bible and the reality of revelation $a b$ extra. But Parker was strong for the worth of man, it was the spring of all his anti-slavery activities, and the higher the appreciation of humanity, not only as it 
is but also as it may become, the easier to include Jesus within its compass. Moreover, emphasis upon the character of Jesus which was taking the place of prophecy and miracle in support of the doctrine of revelation, together with acknowledgment of the divine possibilities of perfection in all men, tended in the same direction. So, little by little and as the convergence of many different lines of inquiry, those who called themselves Unitarians were bringing religion within the sphere of the natural and the human. Was the result to be deism, or natural religion, to the entire rejection of the Supernatural ? So it appeared, and the orthodox cried triumphantly, "We told you so! From the beginning infidelity was latent in Unitarianism and now it has become patent to all men." With pathetic indignation the Unitarians denied that it was so, and begged that they be not held responsible for Parker's utterances, which indeed did not represent at all the Unitarian orthodoxy of the time. But if Parker's criticism was sapping the idea of revelation and so bringing the supernatural within the domain of the natural, a contrary tendency in him, indicated by his " intuitions," was leading in the opposite direction, to the inclusion of the natural within the supernatural. And here we meet Emerson with his teaching of the supernaturalness of the natural.

Draw if thou canst the mystic line

Severing rightly his from thine;

Which is human, which divine.

God, the one in all, shining through all commonplaces and all mysteries, enlightening man from within, propulsive force toward all perfection - this was Emerson's sublime message. If, as Emerson complained, the Unitarians of his time had forgotten that men were poets, his song made them mindful of their divine inheritance. With Emerson comes 
the great turning point in the theological history of Unitarianism.

Remarkably enough, his influence was immeasurably aided by the progress of scientific research. The One in all of which he spoke seemed to be affirmed by the theories of conservation of energy and matter, and most of all by the doctrine of evolution which he had poetically anticipated. So the doctrine of immanence became central in Unitarian theology and preaching. In its light most of the old questions lost significance or presented themselves in quite different forms. If earlier Unitarians had put the accent on Arians, the followers of Emerson threw it on the Unit. The unity of God and of man, - with God on the one hand, with the world on the other, - this was the full-throated paean of the prophets, thinly imitated, it must be confessed, by many a twitterer besprinkled with the spume of Transcendental speech but unbaptized into the depths of its thinking. On the whole, however, this was in Unitarian theology a period of thinking in terms of the comprehensive and universal, an age of reconciliation which sweetly resolved all differences into a large and amiable synthesis. Accordingly views once vehemently opposed came to be regarded as partial glimpses of universal truth. Theology became one with religion, wherein all intellectual differences expired. "When I rest in perfect humility, when I burn with pure love, what can Calvin or Swedenborg say?" Moreover, wherever Emerson's influence extended among Unitarians, the type of piety underwent a wondrous change - brogans were transformed into the winged sandals of Hermes. Only after a generation did the problems arising out of this habit of thought demand attention - but problems there were. For if God be in all, then he is in the terrible as well as in the lovely, in the earthquake which overthrows cities and in the fire which consumes man's most treasured possessions, 
no less than in the still small voice in the human soul. If God is in all, can he be a moral God? Furthermore, if man is thus incorporated in nature, does it not follow that he, like nature, is under the reign of law, and what then becomes of his freedom? Thus it becomes evident that the course of Unitarian thought presents one of the most remarkable curves in all theological history. It began as a human protest against Calvinism with its immoral God and its denial of human worth and freedom, only to swing round into a Calvinism of immanence where the goodness of God and the freedom of man must again be doubted if not denied. From Edwards to Emerson, from the Calvinism of transcendence to the Calvinism of immanence - that was the spiral curve of progress, and today the Unitarians have been brought by the course of their own thinking to the same problems which their fathers faced in different form, only now they are problems arising out of their own thoughts and not from those of their opponents. The spiral is complete and a new period in Unitarian theology must now begin.

To the same point have many of their former adversaries been brought, although by somewhat different paths. They too were students of the Bible and accepted the results of criticism, they too followed the investigations of science, they too learned to know other religions, they too learned of Emerson and Emerson's teachers. It is not for us here to trace the course of orthodox thinking but a few suggestions may be in order.

The crux of Calvinism had always been how God could be just and still punish men who had no freedom and hence could have no responsibility. To remove this difficulty Edwards introduced into New England thinking a distinction which he deemed all important between natural and moral ability. The distinction has become so nearly obso- 
lete now that when a few years ago in the course of a lecture before the Harvard Summer School of Theology I ventured to expound it, a veteran Congregational minister came to me afterwards and with tremulous voice remarked that it had carried him back to the days of his youth and almost made him feel young again. Memory of the incident emboldens me to repeat the explanation here. Suppose I should be asked to do an errand on Washington Street immediately after the close of this lecture, and on leaving the church should be so unfortunate as to break my leg in that case I could fairly plead a natural inability to do what was asked of me. But if I were lazy or churlish and therefore refused, my inability would be moral and not natural. Now, according to Edwards, man has natural ability to do the will of God, all the machinery for executing this will is at his command as truly as it is at that of a regenerate man, but it is man's will that is at fault hence man has perfect natural ability to perform all the commandments of God, and having natural ability he may justly be punished notwithstanding his total moral inability. It was a nice distinction, looking, if one may say so with all deference, like an attempt to worry out barely enough freedom for a man to be decently damned on, but it was used to excellent purpose and had unanticipated consequences. Preachers, especially those of the revival sort among the Hopkinsians, dwelt upon natural ability with ever increasing emphasis, which however rested, as time went on, more upon the noun than the adjective. They whispered natural and shouted ability. Meanwhile the doctrine of moral inability slipped imperceptibly away, until, almost before it was realized what was happening, the distinction was out of mind, full ability was getting itself preached, and the preachers were trying to persuade themselves and others that nothing else had ever been 
meant. So to all intents and purposes the anti-Unitarian ministers had dropped the doctrine of divine sovereignty and were affirming human ability and freedom as stoutly as their old-time opponents. Indeed, it is probable that there are very few Trinitarian churches in New England, even in the remote back country, where the old doctrine of man would be any more acceptable today than it would in the Unitarian church across the village green.

At other points also there has been change. In Emerson's Journal for 1842 , is this significant entry: "Edward Washburn told me that at Andover they sell shelvesfull of Coleridge's Aids to Reflection in a year." Coleridge stood for the same cast of thought as Emerson and Robertson and Maurice, and in particular, Bushnell was strongly influenced by him and in his turn deeply influenced Phillips Brooks. Unitarians often flatter themselves that they have produced the change which has come over New England orthodoxy and doubtless they deserve some of the credit, or blame, but their direct influence seems to me slight compared with the general influences to which both they and their neighbors have alike been exposed. May I very briefly specify two or three of the changes.

The doctrine of the Trinity is interpreted to mean the doctrine of a differentiated unity. If this is what it means I suppose it would be unobjectionable to most Unitarians, although they would wonder a little why the differentiation should be merely threefold and not coextensive with the race and indeed with the whole world, where individual distinctions are supposed to be protected from swamping by this doctrine taken philosophically. There is also a joyous recognition of the humanity of Christ, and the doctrine of the two-fold nature is sometimes held to mean that in him as in us all there was both a conscious and a subconscious being, or in more scientific terms a nature inherited 
from the past and a nature prophetic of the future, an animal inheritance and a forward-driving spirit. That is not at all what the doctrine originally meant; but if that is what it means now, I fancy there would be little Unitarian objection to the idea, which instead of separating Christ from humanity now integrates him with the race by the implication in him as in us all. The dogma of human depravity has suffered an amazing transformation either into a doctrine of heredity, reaching back not to Adam but to animals, or into an affirmation of the social nature of man and the influence upon him of his environment. Satisfaction and moral government theories of the atonement have largely given place to one or another form of the moral influence theory, which is not in the least offensive to Unitarians. So the two bodies have arrived each in its own way at substantially similar theological conclusions on the points once at issue.

Furthermore, the social spirit has seized upon both alike. Solidarity not individuality is the master word on both sides. Individual sin is preached less pungently than of old but both sides vie with each other in the trenchancy of their condemnation of social sin. What must I do to be saved? is now a social cry, and I fancy both parties are in reasonable accord in holding that the way of salvation is the way of life that was in Christ Jesus. The same problems are before both. In the course of events both have been led to about the same position and are facing the same theological and social problems with virtually identical mental habits and equipment, and in the same spirit.

At the beginning of the last century, Andover Theological Seminary and the Harvard Divinity School symbolized the divided fellowship. Each went its own way for a century, but exactly one hundred years after its establishment Andover removed to Cambridge and now both schools are working together and their students mingle indiscriminately 
in class-rooms and in friendly fellowship. Neither school has sacrificed one iota of its independence, each is as autonomous as it ever was, but they work together in happy good fellowship. May we not hope that this will prove an effective symbol of a reconciliation yet to come between the two parts of the ancient Congregational order, in which each shall maintain its own integrity and both shall labor together at the social and theological problems which lie before them both! Should this indeed come to pass, the words used at the Commencement of 1909 by President Lowell in conferring an honorary degree upon one of the Andover Trustees who had labored zealously and successfully for the affiliation would take on prophetic meaning, - " Charles Lothrop Noyes - pastor and preacher - who in these latter days has helped to bring nearer together those whom the blindness of man had put asunder." 



\section{III}

\section{THE BAPTISTS}

GEORGE E. HORR 



\section{THE BAPTISTS}

$7 \mathrm{HE}$ Reformation in England developed three distinct

1 stages and the present situation of English-speaking Protestantism represents survivals of each of them. The Established Church of England represents the first stage. It is characterized by two features - the repudiation of the papal supremacy and a reformation in doctrine. The second stage is represented by historic Puritanism, which, in addition to the repudiation of the papal supremacy and a reformation in doctrine, sought to reform ritual. This movement, beginning in the vestment controversy, came to stand for a simpler form of worship, and a more democratical polity. The third stage is represented by Separatism, or Independency, and adds to repudiation of papal supremacy and a reformation of doctrine and of ritual and polity, a fresh criticism and analysis of the Church itself.

The early English Separatists were confronted by a conception of the Church which regarded it as a great corporation, practically coextensive with the nation. Archbishop Whitgift spoke for Elizabeth when he said that the English commonwealth was the English church. That is the theory that Hooker elaborated twenty years later in his Ecclesiastical Polity. The early English Independents, following Robert Browne, said that a man is not necessarily a Christian because he is an Englishman, and one who is not a Christian has no title to membership in a Christian church. The Independent or Separatist movement, which gave birth to the English Congregational and Baptist denominations, was 
based on a conviction that a church should be composed only of those who are Christians, that is, of those who have personally exercised faith in Christ.

In the eyes of the Independents a church is not a corporation composed of persons who are held together by some tie of locality, birth, or principle of succession. It is a body of professed believers in Christ. The tie that holds them together is that of a common spiritual experience. The continuity and vitality of the organization reside in the possession of the spirit of Christ. Men are not born into the fellowship of the Church. They enter it as their own voluntary act by divine grace.

A shipwrecked company cast on a desert island, rescuing a New Testament from the waves, may have their hearts so touched by the Gospel and so respond to Christ that they may constitute as valid a church as was ever founded. They may have the essential notes of a true church, - faith in Christ, confession of Him, association for worship, work, and discipline.

The Baptist group among the Independents applied this central principle in a more thoroughgoing manner than their Congregational brethren. Probably at first only a few realized the implication of the simple statement that what gives one a title to membership in a Christian church is that inward response of the soul to Christ that constitutes Christian faith.

This emphasis upon spiritual experience led a few farvisioned men to see that it logically involved the principle of religious liberty and the separation of church and state. If this personal response of the soul to Christ is so precious that it is the heart of religion, then it must be voluntary, absolutely without restraint. It is a grievous wrong to any soul to coerce its life toward God. As a matter of fact, it cannot be done, and the attempt to do it by the power of the State 
results in innumerable hypocrisies. This is not to say that there are not many sincere believers when the power of the State is used to maintain and propagate religion; it is to say that these believers are not and cannot be produced by the State.

Professor Platner has called your attention to the Gainsborough-Scrooby church of Independents. From the Scrooby branch came the church at Leyden and Plymouth, Massachusetts. From the Gainsborough branch, after a migration to Amsterdam and a return to England, came the first Arminian Baptist Church in London, which in I6 I I issued a Confession in which occurs this declaration:

The magistrate, by virtue of his office, is not to intermeddle with religion, or matters of conscience, nor to compel men to this or that form of religion or doctrine, but to leave the Christian religion to the free conscience of everyone and to meddle only with political matters. Christ alone is the King and Lawgiver of the Church and Conscience.

Robert Browne twenty years before had approached this position, but recent discoveries of his lost writings make it clear that he was very far from rising to this height. And Professor Masson in his Life of Milton, quoting these clauses in the Confession of I6II, says that this

is the first expression of the absolute principle of liberty of Conscience in the public articles of any body of Christians. Thus from a dingy meetinghouse somewhere in Old London there flashed out first in England the absolute doctrine of liberty of conscience. . . . Not to the Church of England, however, nor to Scottish Presbyterianism, nor to English Puritanism at large, does the honor of the perception of the full principle of liberty of conscience and its first assertion in English speech, belong. That honor has to be assigned, I believe, to the Independents generally, and to the Baptists in particular.

It should be noticed that this doctrine of religious liberty is to be sharply distinguished from the doctrine of Toleration with which it has often been confused. Toleration is for you 
to say to me, I will permit you to exercise such practices in religion. Liberty is for you to say to me, I do these things not because you allow me, but because I have a right to follow my conscience independently of your permission. Toleration involves a permission that might rightfully be withheld. Liberty involves a right not dependent upon another's allowance.

Your attention has already been called to the fact that among the Separatist movements was the so-called LondonAmsterdam Church led by Greenwood and Francis and George Johnson. The so-called Jacob-Lathrop-Jessey Church in London was one of the heirs of this organization, and it was in this church that there arose the discussion about baptism which fixed the lines of division on this matter between the Baptists and the Congregationalists. Just as there emerged in the Gainsborough-Scrooby Church a party which saw clearly and strongly emphasized the principle of religious liberty, so in the Jacob-Lathrop Church there emerged a party which came to hold the views of the modern Baptists as to the subjects of baptism and as to the form of the ordinance.

Three matters were under discussion in this church which should be sharply distinguished: - First, successional baptism; in other words, was there an unbroken line of baptized persons from the days of the Apostles through whom what was called "valid" baptism had been transmitted? Secondly, believers' baptism; in other words, could the ordinance be rightfully administered to anyone except after his confession of personal faith in Christ? This question of course was answered in a way that involved the most sweeping denial of the scripturalism of infant baptism. Thirdly, what was the mode of baptism enjoined in the New Testament? This question was answered by the Baptist party to the effect that clearly immersion was the only Scriptural mode. 
In this discussion in the London church everything for a time was inchoate and unsettled. Some held to successional and believers' baptism and scrupled at immersion; others to believers' baptism; others to infant baptism and immersion, which was the position of the rubrics of the Established Church. But there emerges from this discussion the Confession of 1644 , representing eight churches, which declared that religious liberty is the right of every Christian man, that baptism should be administered to believers only and that the only mode is immersion.

It is not clear just what mode of baptism the General Baptists who put forth the Confession of I6II practiced. Probably it was immersion, but by 1633 it is clear that both the General or Arminian Baptists and the Particular or Calvinistic Baptists were moving strongly to the positions taken in the Confession of 1644, - Religious Liberty, Believers' Baptism, and Immersion.

Behind all this movement in England was the influence of the Anabaptism of the Continent dating a full century earlier. It had two forms, the German and the Swiss. The German was more socialistic than the Swiss and the extremists of the party had brought a reproach upon the whole movement from the outrages and immoralities of Münster. This stigma still abides in Germany and even Ranke identifies the religious life of Providence, Rhode Island, with that of Münster. This identification was one reason for the bad odor in which the Baptists, or Anabaptists as they are called in the old documents of New England, were held. Anabaptism connoted much the same notions as Anarchism does to the modern mind.

The genius who rallied the scattered fragments of Anabaptism after the disgrace of Münster was Menno Simons, whose name and influence are perpetuated in the Mennonite churches of Holland and of this country. But long before 
the English movement that I have attempted to describe crystallized in the English Confessions of I6I I and I644, the Anabaptists of the Continent were maintaining the doctrine of religious liberty, of believers' baptism, and inclining toward the practice of immersion. And while it is difficult to trace organized churches of refugee continental Baptists in England, it is clear that the influence of small groups was strong upon the rising tide of Baptist sentiment in the ranks of the Separatists.

In view of these circumstances it is not strange that there should have been an infiltration of Baptist ideas into the earliest settlements of New England.

The outstanding illustration of this, of course, is the career of Roger Williams. John Fiske has admirably characterized the character of Williams, and his great contribution to religious and political thought which caused Bancroft to class him with Newton and Kepler as a benefactor of mankind. I quote his comprehensive and judicial paragraph:

Among all the Puritans who came to New England there is no more interesting figure than the learned, quick-witted, pugnacious Welshman, Roger Williams. He was over fond of logical subtleties and delighted in controversy. There was scarcely any subject about which he did not wrangle, from the sinfulness of persecution to the propriety of women wearing veils in churches. Yet with all this love of controversy there never lived a more gentle and kindly soul. Within five years from the settlement of Massachusetts this young preacher had announced the true principles of religious liberty with a clearness of insight quite remarkable in that age. . . The views of Williams, if logically carried out involved the entire separation of church from State, the equal protection of all forms of religious faith, the repeal of all laws compelling attendance on public worship, the abolition of tithes and of all forced contributions to the support of religion. Such views are today quite generally adopted by the more civilized portions of the Protestant world, but it is needless to say that they were not the views of the seventeenth century in Massachusetts or elsewhere (The Beginnings of New England, pp. II4-II5). 
Many attempts have been made to remove from the authorities of Massachusetts Bay the reproach of having banished Williams under cruel conditions. Dr. Henry M. Dexter is probably correct in his contention that the Massachusetts Bay Company "was simply a private corporation chartered by the Government for the purposes of fishing, real estate improvement, and general commerce." Undoubtedly, the Company was within its strictly legal rights in banishing Williams or anyone else to whom it took a dislike. But this is not the defence of the banishment put forth by contemporaries. They knew well that the Massachusetts Bay Company was far more than a trading corporation. The promotion of a profitable stock company was not at all the aspect of the enterprise that made an appeal to twenty thousand English Puritans. The impulse that led to this great movement and continued throughout it was well expressed by the Rev. Francis Higginson when he said: "We go to practice the positive part of church reformation; and propagate the Gospel in America" (Magnalia, I629, III, sec. I, p. I2). ${ }^{1}$ Bitterly as the Baptists suffered from the Massachusetts Bay theocracy, they do it the credit of not attributing to it narrow secular motives. John Cotton and John Winthrop were conscientious men. They did not apprehend the principle of religious liberty. They only thought, like Saul the persecutor, that they were doing God service.

In his speech on the dissolution of Parliament in 1655 , Cromwell described the fault of both Presbyterians and Independents when he said:

Is it ingenuous to ask liberty and not give it? What greater hypocrisy for those who were oppressed by the bishop to become the greatest oppressors themselves so soon as their yoke was removed?

1 Cf. John White in Planters Plea. 
There is some reason for doubting whether or not Williams at the time of his conflict with the Massachusetts Bay Colony apprehended the principle of religious liberty as clearly as did the London Baptists of I6II. Certainly at that time he made no statement of it that matches the admirable clearness and precision of the paragraph relating to this matter in the creed of the Smyth-Helwys Church. The strong probability is that though one of the grounds of his offence and a principal accusation brought against him was his doctrine that magistrates might not punish breaches of the first table (and it can be shown that each of the points of conflict with the Massachusetts authorities, - such as the necessity of complete separation of the colony from the English Church, the illegality of the patent, the impropriety of using the cross on the military colors, the wrongfulness of compelling attendance at public worship, and the sacrilege of requiring an unregenerate person to take the oath, - are more or less closely connected in logic with his central principle of religious liberty), yet the clear and masterly apprehension of that principle which we see in The Bloudy Tenent of Persecution for Cause of Conscience was the product of the growth of his ideas, and their clarification by experience and reflection.

History is rendering a tardy justice to the memory of Williams. The circumstance that the leaders of the Bay Colony were almost without exception university men, skilled in letters, gave them a marked advantage in impressing their views upon posterity. The defenders of Williams have not always been a match for their opponents, but Williams is his own best defender. A man who could win and hold the friendship of Sir Edmund Coke, John Winthrop, Sir Harry Vane, and John Milton, and enjoyed " close discourse" with Oliver Cromwell, is his own best champion, and the new appreciation of Williams's personality and of 
his contribution to the cause of human liberty has come from the more careful study of his own works.

The literary style of Roger Williams, like that of John Cotton, is somewhat crabbed and involved. They wrote with haste, and poured forth their ideas upon paper without much care as to their order or best expression. But occasionally Williams, in writing on religious liberty, is conscious of wings and takes an almost lyrical flight. For example, in speaking of the armies of truth he frames a sentence that is worthy of Milton or of Jeremy Taylor. "The armies of Truth," he says, "like the armies of the Apocalypse, must have no sword, helmet, breastplate, shield, or horse, but what is spiritual and of a heavenly nature."

The church which Williams gathered in Providence has generally been regarded as the first Baptist Church organized in America, March 16, I639, though this is contested by those who hold that the church organized by John Clarke at Newport antedates this. It is certain that those who had been Baptists in England found, on emigrating to Massachusetts Bay, that living was more comfortable in Rhode Island.

We should not omit to notice that Roger Williams's connection with the Providence church was short. He parted with the company he had gathered because of his doubts about the validity of his own baptism. The apostolic succession had been interrupted and apostolic authority had ceased. In this curious contention, carrying over the ideal of apostolic succession to baptism, as the Established Church in England had applied it to the ministry, we have the echoes in America of the discussion which at that very time was agitating the Jacob Church in London.

It is of interest to note that Henry Jacob subsequently emigrated to Virginia; and John Lathrop in 1634 , accompanied by about thirty members, emigrated to New England, settling in Scituate and subsequently in Barnstable. This 
leaven of Anabaptism frequently reappears in the ecclesiastical history of New England.

The bitter animosity of the Massachusetts Bay theocracy to the Baptists is shown by the following statute of the General Court, November 23, 1644:

For as much as experience hath plentifully and often proved that, since the first rising of the Anabaptists, about one hundred years since, they have been the incendiaries of commonwealths and the infectors of persons in main matter of religion, and the troublers of churches in all places where they have been: - and that they who have held the baptizing of infants unlawful have usually held other errors or heresies together therewith, though they have (as other heretics use to do) concealed the same, till they spied out a fit advantage and opportunity to vent them by way of question of scruple: - and whereas divers of this kind have, since our coming into New England, appeared among ourselves, some whereof have (as others before you) denied the ordinance of magistracy, and the lawfulness of making war, and others the lawfulness of magistrates, and their inspection into any breach of the first table:-- which opinions if they should be connived at by us, are like to be increased among us, and so must necessarily bring guilt upon us, infection and trouble to the churches, and hazard to the whole commonwealth,

It is ordered and agreed that if any person or persons within this jurisdiction either openly condemn or oppose the baptizing of infants, or go about secretly to seduce others from the approbation or use thereof, or shall purposely depart the congregation at the administration of the ordinance, or shall deny the ordinance of magistracy or their lawful right or authority to make war, or to punish the outward breaches of the first table, and shall appear to the Court wilfully and obstinately to continue therein after due time and means of conviction, every such person or persons shall be banished from the colony.

The reasons for this extreme hostility of the Bay Colony leaders to the Baptists are probably threefold.

In the first place, as I have already suggested, the Baptists were identified in the public thought with the Münster fanatics. The term Anabaptist came to have much the same connotation we now attach to the label Anarchist. It was 
a general term of opprobrium. It is now clearly established that some at least of the Münster party, so far from being in any true sense Baptists, came to practice infant baptism. But the German and Swiss reformers took little pains to examine or treat fairly the men who carried their own principles further than they desired.

In the second place, the denial of infant baptism undoubtedly involved a most insidious and effective attack upon the Massachusetts theocracy. Rev. Thomas Cobbet, minister in Lynn and afterward in Ipswich, in a letter to Increase Mather, states this clearly. He says:

And $I$ add theyr very principle of makeing infant Baptisms a nullity, it doth make at once all our churches, \& our religious Civill state and polity, and all the officers \& members thereof to be unbaptized \& to bee no Christians \& so our churches to bee no churches; \& so we have no regular power to choose Deputies for any General Court, nor to choose any Magistrates (Mass. Hist. Coll., Vol. XXXVIII, p. 29I).

A third reason for this hostility to the Baptists was that the idea that a sound body politic could possibly be built on the principle of religious liberty was totally inconceivable to the Bay Colony people. The Half-Way Covenant was the utmost concession that could be made, and that almost rent apart the theocracy. Furthermore, some of the earlier experiences of the Providence Plantations with fanatics and disturbers were not such as to commend the doctrine of religious liberty for which the Baptists stood.

The Newport church appears to have been more zealous and to have been led by abler men than the Providence church. John Clarke, the pastor, was an educated man and had some property, Mark Lucar, a leading member, had been prominent in the Jacob-Lathrop church in London and Obadiah Holmes appears to have been educated at Oxford.

In 1649 an attempt was made by these men to organize a church at Seekonk, now Rehoboth. Roger Williams in a 
letter to Governor Winthrop refers to this movement in these words:

At Seekonk a great many have lately concurred with Mr. John Clarke, and our Providence men, about the point of a new baptism and the manner by dipping; and Mr. John Clarke hath been there lately and hath dipped them. I believe their practice comes nearer to the first practice of our great Founder, Christ Jesus, than other practices of religion do (Narrag. Club, Vol. VI, p. I88).

Seekonk was within the territory of the Plymouth Colony, but the Massachusetts Bay people, although they could not deal with the matter directly, sent a note to Plymouth (October, r649) in which they said:

Particularly we understand that within this few weeks there have been at Seakunke thirteen or fourteen persons rebaptized (a swift progress in one town), yet we hear not if any effectual restriction is entended thereabouts. Let it not, we pray you, seem presumption in us to mind you hereof, nor that we earnestly intreate you to take care as well of the suppressing of errors as of the maintenance of truth (Mass. Col. Records, Vol. III, p. 74).

But the heresy could not be kept out of the Bay Colony any more than out of Plymouth. Referring to the Anabaptists in the Colony in I646, Gov. Winslow said, "We have some living among us; nay some in our churches of that judgment" (Magnalia, II, p. 459).

The hostility to the Baptists soon had three concrete manifestations in the Bay Colony. The first was the whipping of Obadiah Holmes.

In July, I651, the Massachusetts authorities learned that Clarke and Holmes and Crandall from Newport were on a visit to a fellow Baptist in Lynn, William Witter. It appears that while the visitors were holding a service in Witter's house they were arrested and subsequently removed to Boston. Clarke and Crandall escaped with heavy fines, 
but Holmes was imprisoned until September, when he was publicly flogged on his bare back. "It was grievous, as the spectators said, the man striking with all his strength with a three-corded whip, yea spitting on his hands three times."

A second specific act of hostility was the deposition of the first President of Harvard College, Henry Dunster, because he had espoused Baptist views.

Henry Dunster was matriculated at Magdalene College, Cambridge. It is worthy of note that John Harvard at Emmanuel College was for two years a fellow student at Cambridge with Dunster. Cotton Mather speaks of Dunster as having exercised his ministry in England. Dunster arrived in Boston toward the latter end of the summer of I640, at the age of twenty or twenty-one. Soon after his arrival he purchased a property in Boston at the northeast corner of Court Street and Washington Street - where the Ames Building now stands - but he had scarcely settled in his new home before he was called to the presidency of the college at Cambridge (August, I640). "Mr. Henry Dunster is now President of this college," wrote Captain Johnson in his Wonder-Working Providence, " fitted from the Lord for the work, and by those who have skill that way, reported to be an able Proficient in both Hebrew, Greek, and Latin languages, an Orthodox Preacher of the truths of Christ, very powerful through his blessing to move the affections."

Harvard was only a school when Dunster took charge. $\mathrm{He}$ is usually reckoned as its first president, since the man who had had charge for two years was dismissed for unworthy conduct. Dunster served as President for fourteen years, and Quincy says of him: "He united in himself the character of both patron and President, for poor as he was, he contributed at a time of its utmost need one hundred 
acres of land towards its support; besides rendering to it, for a succession of years, a series of official services, welldirected, unwearied and altogether inestimable."

President Dunster was apparently led by the treatment accorded Clarke and Crandall and Holmes to examine the matter of baptism for himself. He found, as he says, that "All instituted Gospel worship hath some express word of Scripture but Paedo-baptisin hath none." In October, I654, Dunster was compelled to resign the presidency, after having been indicted by the Grand Jury for " disturbing the ordinance of infant baptism in the Cambridge Church." Cotton Mather says:- "His unhappy entanglement in the snares of Anabaptism filled the overseers with uneasy fears, lest the students by his means should come to be ensnared." Quincy, in his History of Harvard College, says of Dunster: "No man ever questioned his talents, learning, exemplary fidelity, and usefulness." Dunster removed to Scituate in the Plymouth Colony, where he became the successor of Chauncy, and Chauncy became his successor at Harvard. He died February 27, 1659.

From one point of view the Harvard Overseers were hardly more fortunate in the successor of Dunster. They elected Rev. Charles Chauncy, the pastor at Scituate, fellow of Trinity College, Cambridge, England. He had come to Plymouth from England in I638. It was known that he held to baptism by immersion only. Some of the Plymouth people worked to secure Mr. Chauncy as assistant pastor, and gave him the liberty of baptizing " as he was persuaded," provided that those who desired "to be otherwise baptized" by another minister should have this privilege. Mr. Chauncy would not agree to this plan, and removed to Scituate. The Scituate church appears to have sheltered all parties. Some held to immersion only, some to adult immersion only, and some to immersion of infants as well as adults. 
A third illustration of intolerance was the attitude of the theocracy toward the organization of a Baptist church in Boston. The movement began in Charlestown and appears to have had the sympathy of President Dunster. The story of the fines and imprisonments decreed upon this faithful group has often been told. For a time the little band had its home in Thomas Gould's house on Noddle's Island in the harbor, now East Boston, but in 1669, some of the members acquired a small house, then building, on Salem Street, Boston, probably with a view of having it transferred to the church. The church bought the house and the land on which it stood February 9, I670, but the stir which this action aroused led the General Court to enact a law the following May, prohibiting the erection and use of a house of public worship without the consent of the freemen of the town and license of the County Court, or special order of the General Court, on penalty of forfeiture of house and land to the county.

The Baptists appear not to have attempted to occupy this house before February, I680. It seemed to them that they had a perfect right to do so, notwithstanding the colonial law, for Charles II, in the interests of Episcopacy, had directed the colonial authorities to allow all Protestants liberty of conscience. The Court, however, acting upon the colonial law, ordered the marshal to nail up the doors of the Baptist meeting-house. The original order is preserved in the First Baptist Church of Boston. The royal decree, however, proved stronger than the colonial law, and after suffering some further annoyance the little band was permitted to use its property.

John Russell, who became the second pastor of the church in July, I679, following Thomas Gould who died October, I675, wrote an account of the sufferings of the Boston Baptist Church which was printed in England, with a preface signed 
by the leading pastors of the English Calvinistic Baptists. But during the forty years that had elapsed since the banishment of Roger Williams from Massachusetts Bay in October, I635, great things had happened in England. The Long Parliament, the Civil War, the Commonwealth, the execution of Charles I, the Protectorate of Cromwell, and the restoration of the Stuarts, had followed in rapid succession. England had been successively High Church Episcopalian under Laud, Presbyterian under the Long Parliament and the Solemn League, Independent and Baptist under Cromwell, and Episcopalian again under Charles II. The Presbyterians and Independents and Baptists had undergone the suffering and humiliation of St. Bartholomew's Day, r662, when two thousand of the ablest and most saintly of the English pastors had been deprived at a stroke of their pulpits. Whatever the English Independents of 1635 might have been in regard to toleration, in I680 they were broadminded and charitable. The English Independents had moved on to a full appreciation and acceptance of Roger Williams's great doctrine; the New England Independents "stuck," to use John Robinson's phrase, where their fathers had left them. These London ministers show in this preface to Russell's tract their amazement that those who had come to the New World to escape persecution should persecute their brethren. "For one Protestant Congregation," they say, "to persecute another, where is no pretence to infallibility in the decision of all controversies, seems much more unreasonable than the cruelties of the Church of Rome towards them that depart from their superstitions."

The English Independents had advanced much further toward the recognition of the rights of conscience than their Massachusetts brethren. The Bay Colony represented a type of thought that prevailed in England two generations 
before, and that type had been perpetuated in New England, while the Independents of Old England had advanced toward modern ideas.

There were at least two incidents that contributed toward a different attitude of the standing order as to the Baptists at the close of the seventeenth century. William Turner, who was one of the group of Charlestown Baptists that organized the church on Noddle's Island, greatly distinguished himself in defence of the Colony. In 1670 Turner was in prison, though Allen and Oxenbridge of the First Church and all the deputies in the Legislature voted for his release, but the magistrates in the Governor's Council were set against it. "Above thirty weeks," he says, "I have been lying in prison, to the possible ruin of my headless family. I am ready to serve this country to the utmost of my ability, in all civil things. In faith and order God alone can satisfy a poor soul."

In the year 1675 , when King Philip launched his conspiracy against the English settlers, Turner, mindful of the promise he had made in prison five years before to serve the country, offered to the magistrates to raise a company among his friends and acquaintances to fight the Indians. At first Turner's offer was refused, but the next year when the fortunes of the war were turning against the settlers, and the flames of burning buildings filled the sky from Casco Bay to Stonington, the magistrates came to Turner, begged him to renew his offer and raise his company. Turner recruited his company mainly from the members and adherents of the First Baptist Church. The officers were members of the church. Elder Drinker was lieutenant, Philip Squire sergeant, and Thomas Skinner clerk. There are thirteen names in the list of the Company he sent to Boston which correspond with the names of the members of the First Baptist Church, and there are twice as many more in this list of men 
whose mothers, wives, or sisters belonged to the Baptist Church.

On February 2I, I676, Captain Turner began his march to Northampton. King Philip's headquarters were at Northfield, and he had another camp at the Falls of the Connecticut, which bear today the name of the doughty Baptist captain, Turner's Falls. The surprise that Captain Turner sprang at this point is a notable episode in New England history and even Increase Mather was enthusiastic in his recognition of the brave exploit.

A second incident that contributed to the good feeling between the Boston Baptists and their Congregational brethren was the attitude of the Mathers toward the Baptists at the ordination of the Rev. Elisha Callender as pastor of the Baptist Church. At this service the right hand of fellowship was given by the aged Increase Mather, and his son Cotton Mather preached the ordination sermon. The appreciation of this courtesy of the Mathers on the part of Thomas Hollis, a wealthy London Baptist, led him to direct his benevolence to Harvard College. The Hollis family contributed the largest amount to the funds of Harvard College - about six thousand pounds - that it received from any one family until well along in the nineteenth century. We must remember that money was then worth about five times its value today.

\section{II}

Possibly the Half-way Covenant has sometimes been overemphasized as a principal cause of the Unitarian separation. The First Church of Boston, which strenuously opposed the covenant and called John Davenport from New Haven to become its pastor in order that that valiant defender of orthodoxy might lead in Boston against the weaker brethren, 
ultimately became Unitarian, while the Third Church, the Old South, which was organized in support of the Half-way Covenant, was the only one of the Boston Congregational churches that did not become Unitarian.

The discussions, however, that centred about the Covenant inevitably had one effect. They called fresh attention to the reasonableness and scripturalness of the Baptist position, that if baptism had any such close relation to church membership as all parties believed it had, only those who gave some evidence of possessing the Christian character should be baptized. The circumstance, however, that the position of the conservatives endorsed the essential correctness of the Baptists, did not make the Baptists any more tolerable to some of the standing order. Still, in almost every community there were some who, however much they might dislike the Baptists, were broad-minded and fairminded enough to see that the acknowledged evils of the Half-way Covenant were a lurid commentary on the peril of departing from the principle that the true basis of church membership must be found in personal Christian experience.

The most important single factor in promoting the growth of the denomination was the Great Awakening itself. In r 740, the third generation of the settlement of New England, the religious impulse that a century before had created the theocracy of the Massachusetts Bay Colony had nearly died out. The causes of this declension have been sufficiently indicated. The second Baptist Church in Boston, now the Warren Avenue Church, was not formed until I743, as a result of the opposition of the Rev. Jeremy Condy, pastor of the First Church, to the Great Awakening, as the EdwardsWhitefield Revival came to be known. The Baptist Church at Kittery, Maine, organized in r682, was broken up by fines and imprisonment, and some of its prominent members, emigrating to South Carolina, gathered in what is now the 
First Church of Charleston, the only Baptist church founded in the Southern colonies in the seventeenth century. In 1765 , the Rev. Hezekiah Smith, a graduate of Princeton, founded the First Church, Haverhill, the oldest Baptist church north of Boston.

The immediate result of the Great Awakening was to run a line of division through New England Congregationalists, separating the formal adherents of the churches from those in whose lives religion was a vital experience. The majority of the Congregational ministers and churches opposed the revival, and it must be said in fairness that the eccentricities and fanaticism that developed in certain places gave some warrant for the antagonism. On the other hand, we can but feel, as we read the records and journals of the period, that a substantial reason for the opposition was the very formality and spiritual deadness into which many of the churches and members had sunk. The Baptist churches also shared in this religious declension, but their insistence on a regenerate membership had prevented their reaping the harvest of evil that the Congregational churches had gathered from the Half-way Covenant. The Baptists at first do not seem to have been enthusiastic about the religious movement, but gradually they came into a warmer sympathy with it. The Congregational churches that supported the revival came to be known as New Lights. And between the New Light Congregational and the Baptist churches there rapidly developed sympathies and affinities which led to some of the most interesting developments of the century.

In some cases the New Light members of Congregational churches sought membership in Baptist churches. In other instances they formed New Light congregations alongside the old Congregational churches.

The religious history of Middleborough, Massachusetts, is typical. Here Isaac Backus became pastor of the New 
Light Congregational church. But soon various questions asserted themselves. What was the Scriptural authority for infant baptism? What is the status of the baptized child in relation to the church? What is the standing in the church of those who, though they were baptized in infancy, unmistakably are not living a Christian life? Such questions greatly troubled Mr. Backus. At one time he preached a sermon repudiating infant baptism and advocating immersion. A few days later he withdrew from these positions, but ultimately, after two years during which he was " much tossed in his mind," he became a convinced advocate of the Baptist principles. The course of Mr. Backus made a serious division in the church and five councils reviewed the situation. At length Mr. Backus became the founder of the First Baptist Church in Middleborough, of which he was pastor for fifty years.

Backus, though a man of excellent parts, had not enjoyed a college training, but he so improved his opportunities for general culture that his History of the Baptists, originally published in three considerable volumes, is one of the standard works for the religious history of New England in the seventeenth century, and George Bancroft characterizes Backus as "one of the most exact of our New England historians" and his work as marked by "ingenuousness, clear discernment, and determined accuracy."

In other towns there was no such discussion as at Middleborough. The New Light congregation at once or gradually became a Baptist church.

In the development of the denomination after the Great Awakening there were three outstanding events.

I. The gradual achievement of religious liberty.

From the very beginning the General Court of Massachusetts had provided for the support of the Christian ministry by taxing all the people. By the law of I638 it was provided 
that " every inhabitant who should not voluntarily contribute to all charges, both in church and commonwealth, proportionately according to his ability, should be compelled thereto by assessment."

The second charter of Massachusetts (I69I) though granting equal liberty of conscience to all but Roman Catholics, required each town to have a minister who should be supported by public taxation, and in I718 the General Court authorized a tax for building and repair of meeting-houses.

In 1728 , however, Baptists and Quakers were exempted from poll taxes for the support of ministers and it became illegal to take their bodies in execution to satisfy any such ministerial rate or tax assessed upon their estates or faculty, " provided that such persons do usually attend the meetings of their respective Societies assembling upon the Lord's Day for the worship of God, and that they live within five miles of the place of such meeting." The names of the Baptists and Quakers who might thus escape the poll tax were ascertained by the County Court, which through its clerk sent lists of the names to the assessors of each town or precinct. Backus in his quaint manner remarks about this legislation:

Here we may see that arbitrary power is always the same nature, in every age, and every country. "Go ye, serve the Lord: only let your flocks and herds be stayed," said Pharaoh. Let their polls be exempted, but their estates and faculties be taxed, said Massachusetts. Herein they imitated him; but in two other points they went beyond him. "Go not very far away," said Pharaoh; Go but five miles, said Massachusetts; though many of their own parishioners, from that day to this, must go much further than that to meeting. Neither did Pharaoh require a list of the people upon oath as these did (Backus, Vol. I, pp. $577-578$ ).

That year the imprisonment of two Episcopalians, twentyeight Baptists, and two Quakers for refusing to pay ministerial taxes on their estates led to an appeal to the Assembly, 
which added an act (November I9, I728) to exempt estates and faculties as well as polls " under the same conditions and limitations as they were before," but these exemptions were to continue only to May, I733.

It would be tedious to recount the minute changes in exemptions and time limits under which the exemptions were valid that were enacted by successive General Courts. The topic of the rights of Baptists, Quakers, and Episcopalians was always under discussion. In some places, as at Sturbridge, the laws were executed with great harshness and cruelty; in other towns the practice was more lenient.

The action of the General Court in $175^{2}$, and afterwards in 1757 , in requiring three other Baptist churches to testify that the church whose members sought exemption certificates belonged to their denomination, was regarded as so unjust that steps were taken and money collected to carry the matter to England.

Most of the Baptist churches were connected with the Warren Association, and the injustice of the law and the abuses under it were so exasperating that a Committee on Grievances was appointed, of which Isaac Backus was chairman for ten years from 1772 .

In 1774, Backus addressed a letter to Samuel Adams in which, arguing from the ground on which Adams was protesting against British oppression, namely, that it was essential to liberty that representation and taxation should go together, Backus made the point that since people do not vote for their representatives in the legislature on account of their ecclesiastical qualifications, these representatives had no right to impose ecclesiastical taxes. The taxes laid by the British Parliament on America are not more contrary to civil freedom than these Massachusetts taxes are to the very nature of liberty of conscience which is an essential article in our charter. 
When the opposition to British oppression came to a head in $\mathrm{I} 774$, and a meeting of the representatives of the colonies was summoned in Philadelphia, September 5, I774, the Baptists were well represented in the New England delegation. Among them was President Manning of Brown University, Dr. Stephen Gano, and Isaac Backus. The presentation of Baptist grievances, however, made so little impression that John Adams is reported to have declared that a change might as well be expected in the solar system as that the great Puritan State would abolish its ecclesiastical laws.

The Baptists incidentally suffered at this time in a new way, for their protest against the injustice with which they were treated gave color to the charge of their enemies that they made their own grievances more prominent than those of the whole people. Backus met this charge in his address to the Congress of Massachusetts, in which he said:

The Baptist churches in this Province as heartily unite with their countrymen in this cause as any denomination in the land, but they denied the right of the General Court to impose upon Baptists the burden of a ministerial tax as they denied the right of the British Government to impose on the colonists the tax of three pence in a pound on tea!

The only immediate modification of the law pressing so severely on Baptists which was accomplished by the War of Independence - that great outburst of resistance to measures that the colonists regarded as oppressive - was that the revised Constitution of Massachusetts asserted " the right and duty of the legislature to authorize and require the several towns, parishes, precincts, and other bodies politic, or religious societies, to make provision at their own expense for the institution of the public worship of God." The actual working of this provision was that where Baptists were a majority they might elect a Baptist as minister of 
the town. In reality it gave to the majority of Massachusetts citizens the right which the Princes of Germany acquired under the famous principle known as cujus regio, ejus religio.

The situation which this compromise created theoretically made the position of the Baptists somewhat easier. Certainly it gave their standing in the community a political and social recognition which up to this time they had lacked. A denomination could not be treated as a company of fanatics who were to be unclassed, when they had a legal right, if they could muster sufficient adherents, to elect from their own number the minister of the town. But this was not the goal the Baptists had set before themselves. In fact, they showed as little appreciation of governmental recognition as the French Protestants manifested when Catherine de Medici flung them a morsel of royal recognition. This law was in no sense the goal of the Baptists. They did not want to rule the New England towns on any such terms. To their thinking it would be exactly as unjust for them to rule their neighbors as it was for their neighbors to rule them.

Practically, however, this new legislation did almost nothing to ameliorate their condition. Persecutions did not cease. Ministerial taxes were assessed and goods were attached. A curious development took place at what is now Arlington. A Baptist church was organized there in I78I, and a pastor was secured in 1783 . The members of the Baptist Church were assessed for the support of the Congregational ministers. Thereupon the Baptists sued the assessors and obtained a judgment in the County Court, which was reversed in the Supreme Court. It was suggested, however, by one of the attorneys in the case that the Baptists might sue the money they had paid out of the hands of the assessors and apply their ministerial taxes to the support of their own minister. This was actually done at Arlington 
and the precedent was followed in other places, but Backus and the other leaders regarded this course as indefensible.

The number of churches that resorted to this device is not readily obtainable, but it must have been considerable. In I8I I, Chief Justice Parsons decided that a religious society must be incorporated by law to have the privilege of this rebate.

A great petition signed by many thousands of persons of every cast of religious doctrine was presented to the Legislature, requesting that the existing laws should be "so revised and amended that all denominations of Christians may be exempt from being taxed for the support of religious teachers, excepting those whose ministrations they voluntarily attend." This was the occasion when the famous John Leland addressed the House. "The petitioners pray," he said, "for the right of going to heaven in that way which they believe is most direct, and shall this be denied them?" In answering the objection that to grant complete religious liberty would be to affront religion and bring unknown judgments on the State, he said: "Since the Revolution, all the old States, except two or three in New England, have established religious liberty on its true bottom; and yet they are not sunk with earthquakes or destroyed with fire and brimstone."

Looking back the comparatively short distance of less than a century, it is almost inconceivable that Massachusetts should have fallen so far behind the general movement of the age and have been so reluctant to come to an act of common justice. The innate conservatism and sense of privilege of a standing order, old prejudices, and sometimes, it is to be feared, the bitter spirit in which rights were asserted, all operated to keep Massachusetts far in the rear of other States. President Eliot composed for one of the inscriptions for the World's Fair at Chicago in I893, this sen- 
tence: Toleration in religion the best fruit of the last four centuries. If this is a true judgment, Massachusetts was slow, very slow, in appreciating it. At length, in I833, after coming before the Legislature at several sessions, an amendment forever separating Church and State in Massachusetts was ratified by the people. And the long struggle in which Baptists had been the most prominent was closed with a triumph.

2. The second event that contributed to the strength of the Baptists was the new interest in education.

In the first hundred years of American history three colleges had been founded, - Harvard in 1636 , William and Mary in 1693, and Yale in I70r. During the next four decades twelve colleges were established. The first four were as follows: the College of New Jersey (now Princeton) in I746; King's College (now Columbia University) in I754, the University of Pennsylvania in 1755 , and Brown University in 1764 .

Harvard and Yale were controlled by the Congregationalists, the College of New Jersey by the Presbyterians, the University of Pennsylvania, King's College, and William and Mary by the Episcopalians.

The reasons that led the Baptists to found a college at Providence have been variously stated. Some of them will not bear examination. For example, it has often been asserted that the religious tests at the existing colleges put Baptist students under peculiar disabilities. But there is nothing in the charters of Harvard, Yale, King's College, or the University of Pennsylvania to bar Baptist students, while at Harvard some of the Hollis scholarships were by preference given to Baptists.

But, however liberal the college charters, there can be no doubt that there was considerable social discrimination against Baptist students. They did not belong to the ruling 
caste, and there can be no doubt that the college students of the day, reflecting the disposition of the Congregational churches toward the Baptists, made the lot of Baptist students uncomfortable. The potent reason, however, that led the Baptists to found a college was the rapid growth of the denomination after the Great Awakening in I740, and the appreciation on the part of the leading men of the great need of education among the rank and file of the churches.

In I740, there were but twenty-one Baptist churches in all New England, eleven of them in Rhode Island. In I768 the Baptist churches in New England numbered sixty-nine, and by I790 they had increased to two hundred and eightysix, having a membership of more than seventeen thousand. There is no such record of rapid growth on the part of any other denomination in the entire history of New England. This increase in members and influence brought the Baptists to self-consciousness, and at once they saw that if they were to hold their own they must have a college in which, whatever the charters of existing colleges might say, the entire scholastic and social influence of the college should not be perpetually drawing Baptist students away from their faith.

Harvard inscribes on one of her gates a beautiful sentence from a contemporary letter:

After God had carried us safely to New England, and wee had builded our houses, provided necessaries for our livelihood, rear'd convenient places for God's worship, and settled the Civill Government; One of the next things we looked for was to advance Learning, and perpetuate it to Posterity; dreading to leave an illiterate ministry to our churches, when our present Ministers shall lie in the Dust.

The devotion and the vision that founded Harvard in I638, founded Brown, one hundred and twenty-six years later, in 1764 . The college did not originate in Rhode Island, but in that other centre of Baptist influence, the Philadelphia Association. In $175^{6}$ the Association had 
established an academy at Hopewell, New Jersey, under the care of Rev. Isaac Eaton. In the papers of David Howell, the first professor in Brown University, there is this memorandum:

Many of the churches being supplied with able pastors from Mr. Eaton's Academy and thus being convinced by experience of the great usefulness of human literature to more thoroughly furnish the Man of God for the most important work of the Gospel ministry, the hands of the Philadelphia Association were strengthened and their hearts encouraged to extend the design of promoting literature in the Society by erecting on some suitable part of the continent a College or University which should be principally under the direction of the Baptists.

It is evident that the purposes of the founding of Harvard and Brown were similar, but the charter of Brown discloses a conception in the minds of the founders of the relation of education to the welfare of the whole community that could only have been inspired by a large outlook upon the function of education. The preamble to the charter gives this reason for the establishment of the college:

Institutions for liberal Education are highly beneficial to Society, by forming the rising generation to virtue, knowledge and useful literature; and thus preserving in the community a succession of men duly qualified for discharging the Offices of life with usefulness and reputation.

A letter written by Isaac Backus to an English friend the year after the college was founded shows how the leaders looked at this enterprise. He writes:

One grand objection made use of against Believer's Baptism has been that none but ignorant and illiterate men have embraced the Baptist sentiments. And there was so much color for it as this, namely, that ten years ago there were but two Baptist ministers in all New England who had what is called a liberal education; and they were not clear in the doctrines of grace. 
In another letter written ten years later he alludes to the fact that Baptists who had sent their sons to Harvard and Yale, "have been disappointed, as the clergy have found means to draw them over to their party."

I need not recount the various steps by which the New Jersey Academy became Brown University. The leaders were James Manning, the first president of the college, a graduate of Princeton; Morgan Edwards, a graduate of Bristol College, England; and Hezekiah Smith, a graduate of Princeton; with Isaac Backus. This was the quartette that carried the great enterprise through to completion. And Baptists have seldom had in one generation four men of superior capacity and devotion.

The charter of Brown University has sometimes been characterized by those who have not studied our early college charters as narrow, because it puts the control of the college in the hands of the Baptists, who have a majority both on the Board of Fellows and on the Board of Trustees.

The charter divided the government of the college among the representatives of the Baptists, the Friends, the Congregationalists, and the Episcopalians. These denominations must be represented in the government of the college. The colleges established before Brown had self-perpetuating governing boards, which almost without exception, and naturally enough, filled vacancies with their coreligionists. Thus it came about that without charter provision, there was not the slightest difficulty in coloring the college instruction and making the college influence a powerful direct factor in the life of the denomination which founded the college. At Harvard and Yale and Princeton this feature of the college work was so emphasized that ultimately each college became identified with a peculiar type of theology. At Brown, in addition to obligatory representation of four denominations on the governing board, it was expressly enjoined by 
the charter that "the sectarian differences of opinion shall not make any part of the public and classical instruction."

It is one of the paradoxes of the evolution of institutions that colleges which remain firmly attached to certain denominations through prescription and the self-perpetuating power of their governing boards should be characterized as non-sectarian, while a college that makes specific provision for the inclusion on its governing board of four religious bodies should sometimes have been characterized as narrowly denominational.

It was a day of small things, of small things at Cambridge and New Haven as well as at Providence. But the seed planted in Providence was good, and Brown University has been one of the principal factors, not only by what it has accomplished itself, but what it has inspired other communities to attempt in raising the educational standards of Baptist ministers and laity.

In I8I5, the Maine Literary and Theological Institution, now Colby College, was established at Waterville, Maine. In 1825, the Newton Theological Institution was founded at Newton Centre. Brown, Colby, and Newton have been the principal agencies of New England Baptists for higher education. Brown has sent out six thousand nine hundred and eleven men; Colby, about one thousand five hundred; and the Newton Seminary, one thousand six hundred and seventy-five.

Professor Brastow of Yale in his work, The Modern Pulpit, probably did not overstate the case when he gave these institutions the principal credit for raising the educational equipment of the American Baptist ministry. In addition to the two colleges and the seminary the Baptists have well equipped academies in all the New England States except Rhode Island, and in Maine four academies act as the principal feeders of Colby College. 
The founding of Brown University at Providence was an indication of the interest of New England Baptists in education, and the cause of still deeper interest. Taking the country as a whole, the Baptists were indifferent to education, and in most cases hostile to specific training for the ministry, even when they appreciated literary culture. The success of the New Light preachers in winning large numbers of converts and in organizing churches produced the conviction that the Gospel needed no aids from human learning, and that, on the contrary, the educated minister would tend to rely on his own resources rather than upon the aid of the Divine Spirit. This was especially true in the South.

When New England Baptists established the Seminary at Newton, the first to be organized by American Baptists exclusively for theological training, it confronted strong opposition. It only succeeded in commending itself by its product and when it was seen that Newton graduates were quite as successful in winning converts as the untrained ministers, and that they reached classes of the community inaccessible to the uneducated preachers, the opposition was lessened. One result of ministerial training was that the Baptists, whose growth had been largely confined to the rural sections, began to make substantial gains in the cities. This demonstration and the impulse that came from it made the New England Baptists the educational leaders of the entire denomination. The educational pioneers of the West and South, for the most part, were trained in New England. During the last twenty-five years there has been something like an educational revival throughout the whole denomination and large sums have been given to our institutions. The clearest-sighted of our leaders see that in the perpetuation and enlargement of this enthusiasm lies, from a human point of view, the fairest prospect of continued denominational efficiency and progress. 
An incidental but important manifestation of the opening of men's eyes to larger horizons was the founding of The Watchman, a weekly religious newspaper, in Boston in I8Ig. The relation of its press to a religious community is like that of the circulation of the blood to the body. It brings part into relation with part, carrying nutrition and stimulus to the whole organism. Almost from the first, The Watchman became a recognized power. During the middle years of the last century, before newspapers and magazines were multiplied, The Watchman held a place in the life of the average Baptist household only second to the Bible.

3. A third factor of great importance in the life of the denomination was the development of the missionary impulse in work both at home and abroad. In this history the one name of Adoniram Judson stands forth preëminent. Judson graduated from Brown University in the Class of I807, and from Andover Theological Seminary in I8ro.

In I8I2, Judson, with three other young missionaries, was sent to the Far East by the American Board of Commissioners for Foreign Missions, which had been recently organized. On the long voyage he busied himself in a study of the Scriptures relating to baptism, for he knew that he should meet in India the English Baptists. As a result of his study he became convinced that the Baptists were right in their view of the ordinance, and he was baptized in Calcutta, September 6, I8I2. Soon after his companion, Luther Rice, followed his example. When Judson's letters to Rev. Dr. Thomas Baldwin of Boston and to Rev. Dr. Lucius Bolles of Salem, announcing his change of view and appealing to the American Baptists for help, were published, Baptists recognized the appeal as a divine call, and May I8, I8I4, eleven States and the District of Columbia sent delegates to a meeting in Philadelphia. The result was the organization of "The General Missionary Convention of the 
Baptist Denomination in the United States of America for Foreign Missions." This is the first considerable work in which American Baptists were united.

In a certain sense the rapid increase of Baptist churches after the Great Awakening was the first factor in creating a denominational consciousness and from that had come Brown University, but it was the missionary enterprise inaugurated in these circumstances, and led by a man like Judson, of rare scholarship, of apostolic devotion, and of a fibre to sustain sufferings that rank with those of the early martyrs, which transformed a group of churches that were as a lump of clay, incapable of transmitting a vibration from particle to particle, into a block of marble responsive through its entire mass to every impulse.

The record of what was at first accomplished appears meagre in the light of our larger undertakings of recent years. It is reported that the contributions of the first year were one thousand two hundred and thirty-nine dollars, and for the first ten years only seventy-three thousand dollars. The question soon arose whether work among the American Indians was not as truly foreign as work in India and Burmah. There was a general conviction that it was, and the impulse from Judson's appeal led to the establishment of missions among the Indian tribes. In 1826 , when we had nine missionaries in Burmah, we had sixteen among the American Indians.

Undoubtedly many mistakes were made. For one thing, too much was attempted. Judson and Rice profoundly believed in an educated ministry. It seemed to be a legitimate thing for the Missionary Society to found a university. This was done and Columbian University was established at Washington, D. C. But when funds that were needed in Burmah were used in Washington, it became evident that the Society must bend its energies to one task. Fortunately, 
however, it was out of their educational interest that there came the theological schools in Hamilton, N. Y., in I8I9, and in Newton in I825. The Society, however, continued the work among the Indians.

In 1826 , there was so much discouragement about the financial outlook of the Society that the Baptists of Massachusetts offered to become responsible for its care and maintenance. This offer was accepted and the headquarters of all the foreign missionary work of the Northern Baptists has been in Boston since that time. Up to 1845 the Society represented the denomination in the entire country, but in that year "The Southern Baptist Convention" was organized with headquarters at Richmond, Va. The division was wholly on the issue of slavery.

The responsibility assumed by the Baptists of Massachusetts with regard to this work has proved larger, perhaps, than our fathers imagined. But the Baptists of New England have rallied splendidly to their great task, and they have amply fulfilled that venturous pledge.

Just now there is a persistent attempt to remove the headquarters of the Society either to New York, the financial centre of the country, or to Chicago, which is nearer the geographical centre. New England will not look unmoved on this transfer, but she may safely challenge either New York or Chicago, in any years to come, to do better proportionately than Boston has done.

It is impossible to say how much the interest in foreign missions among Baptists that dates from the appeal of Adoniram Judson and Luther Rice has done for the Baptist churches of the United States. Practically, it made them a denomination. It enlisted them in an enterprise that interpreted to them anew the Christian Gospel: it broadened the range of their sympathies and interests to the compass of the globe, and it created a new sense of common brother- 
hood. The centennial year of our foreign missionary work was observed last summer, and it was noticeable how in both North and South there was a common recognition of the fact that Judson's appeal, long preceding any division between North and South, had created a common history and a common consciousness in which reside the fairest hopes for a perfect reunion of these two sections of our present denominational life.

Previous to $\mathrm{I}_{32} 2$ there had been sporadic attempts to evangelize the expanding West, but the movement to enlist the resources of the entire Baptist membership of the States of the Atlantic Seaboard came from New England. Dr. Jonathan Going of Worcester, and Dr. Lucius Bolles of Salem made a tour of the West and reported that the time was ripe " to arouse the Baptist community throughout the United States to systematic and vigorous efforts in the cause of domestic missions and that a general home mission society should be formed." The result was the formation of the American Baptist Home Mission Society in I832, with headquarters in New York City, where they have since remained. Last year the total income of the Foreign Mission Society was $\$ \mathrm{I}, \mathrm{II} 4,420$, and of the Home Society, $\$ 673, \mathrm{I} 66$.

A few words are proper concerning the type of theology that has prevailed in the Baptist churches of this country. In England there have been from the first both Calvinistic and Arminian Baptists. The latter, known as General Baptists, made their influence felt chiefly in Virginia, but they have never been a numerous body. The Baptists of New England were for the most part Calvinists, and when they became Arminian they became so because they were moderate Calvinists, and moderate Calvinism shades off inevitably into Arminianism. Still, we have had churches in the North, like the First Church, Providence, that have 
always been Arminian. The Southern Baptist churches, except the small number that trace from the English General Baptists, have been Calvinistic, with the Philadelphia Confession, which is the Westminster Confession slightly revised to bring it into conformity with the Baptist doctrine of the church, as their symbol.

It cannot be fairly said that Baptists, as a whole, are either Calvinists or Arminians. Both types have been cultivated and recognized. The principal reason for the predominant Calvinism of the South is probably to be found in the fact that the South was largely evangelized from the Philadelphia Association. And an incidental occasion for the Arminianism of some of the New England Baptist churches was their reaction from the Calvinism of the New England Congregational churches, at whose hands the early Baptists suffered so many injustices.

In the South and West, and to a small extent in the North, the extreme Calvinistic churches carried out their views of the divine sovereignty to the extent of opposing missions and evangelization of all kinds; indeed, they were hostile to any form of Christian activity. These bodies have become practically negligible.

In the North an interesting revolt from the Calvinism of the New Hampshire churches was led by Benjamin Randall. In September, I770, Randall, then a godless youth, heard Whitefield preach at Portsmouth. Two days after this Whitefield died at Newburyport. Randall was greatly impressed by Whitefield's death, and became an active Christian. Five years later he withdrew from the Congregational Church of which he was a member, on account of infant baptism, and united with the Baptist Church of Berwick, Maine. Randall appears to have had remarkable power and success as an evangelist. His preaching was of the type of 
Wesleyan Arminianism. By reason of this he was disfellowshipped by a local council of Calvinistic Baptist churches, and thereupon he organized at New Durham, N. H., in I 780, a church in sympathy with his views. This is the mother-church of the so-called Free Will Baptists. The persistence of the regular Baptists in calling these dissidents "Free Willers" led them to adopt the name, but it is not of their original choice. By I8Io the connection had I3O churches, ito ministers, and 6,000 members.

In I9II, the date of their union with the Regular Baptists, the Free Baptists had two well equipped colleges, Hillsdale College, Michigan, founded in 1855 , and Bates College in Lewiston, Maine, founded in 1863 , with a number of schools of the lower grade, 834 churches, 9r4 ministers, and 33,600 church members.

The happy union of the Free Will and the regular Baptists on October 5, I9II, did much to solve the vexed communion question for the Northern Baptist churches. The Free Baptists for the most part practiced open communion, and the regular Baptists restricted communion; in other words, they held that the communion was only rightfully administered in Baptist churches to believers who had been immersed. At one time this question threatened to become an issue that might readily lead to division. The union of which I have just spoken has resulted in putting this whole matter strictly within the jurisdiction of the local church.

In general, it may be said that while there have been differences and divisions among Baptists like those just cited, their doctrinal position throughout their history in the United States has been strongly evangelical. There has been no appreciable movement toward Unitarianism, as there has been among the Arminian Baptists in England. Considering the looseness of their ecclesiastical organization, 
and the comparatively slight esteem in which they hold creeds, this substantial unity as to the teachings of the Gospel has been marvellous.

The development of organization among Baptists affords an unwritten chapter in recent history. The independency of the local church has always been a cardinal tenet. In early days it was exceedingly difficult to induce Baptist churches to combine in an association or convention. The Warren Association of churches was formed with the utmost difficulty. When in $I_{7} 67$ the representatives of the church met under the leadership of James Manning and Hezekiah Smith to organize an association, only four saw their way clear to unite in the enterprise. These were the Warren of Rhode Island; the Haverhill, Bellingham, and Second Middleborough of Massachusetts. Even Isaac Backus, who afterwards came to recognize the great value of the coöperative work, held back. His church wrote that they "waited until they could be satisfied that the Association did not assume any jurisdiction over the churches."

Notwithstanding the fact that most Baptist churches in the United States are members of a local Association, the churches are jealous of their independency, and the Association's powers are simply advisory. State Conventions, which are simply larger associations of churches for missionary purposes within the States, are organized in every State. In the New England States the State Conventions administer considerable funds for helping the weaker churches, for evangelization, and of late years for missions among our foreign population. Every attempt to constitute Conventions on a system of representation from the Associations has been firmly resisted. The unit of representation, both in the Association and in the State Convention, has always been the local church. 
I76 RELIGIOUS HISTORY OF NEW ENGLAND

The total number of Northern Baptists at the present time is $1,291,668$. The Southern Baptists number 2,552,633, and the colored Baptists, $1,984,95^{2}$. The total number of Baptists in the United States of all names is 6,I29,467, making it the second largest Protestant denomination in the United States. In New England there are I,333 Baptist churches, with 165,383 members. 


\section{THE QUAKERS}

RUFUS M. JONES 



\section{THE QUAKERS}

THE Quakers came into existence as a distinct religious 1 Society during the period of the English Commonwealth, though the work of preparation for their movement had been under way since the beginning of the Reformation. ${ }^{1}$ The leader of the movement and the founder of the Society was George Fox, who was born in Leicestershire, of humble but rugged, God-fearing parents in 1624 , and who began his mission as an itinerant lay preacher in 1648 . From the year 1652, when Fox fell in with bands of religious "Seekers" in the northern counties, the movement grew rapidly, attracted wide public notice, and because of its radical, uncompromising views and practices brought much persecution upon its exponents.

Fox and his followers called themselves at first "the children of the Light," because they professed to be led, guided and inspired by a divine and heavenly Light, revealing the Truth to their souls, and they called their preachers " the publishers of Truth." Later, by a happy insight, they adopted the name "Friends," and, as they did not approve of applying the word Church to any denomination or branch of Christendom, since it belonged to the whole body universal, they took the more modest word, and called themselves " the Society of Friends." By the public, however, almost from the first, they were nicknamed "Quakers," probably because in their meetings they trembled with a physical resonance, stirred by their deep and intense emotions. ${ }^{2}$

1 I have traced the steps of this preparation in my Studies in Mystical Religion, 1908, and Spiritual Reformers in the Sixteenth and Seventeenth Centuries, 19r4.

2 George Fox assigned the origin of the name, "Quaker," to an incident in a court of justice (Journal, I, p. $5^{8}$ ) but the psychological ground for the name is recognized by many early Friends. 
The movement was, from its earliest beginning, outreaching and missionary in spirit. Its exponents were possessed with a faith that they had rediscovered "primitive Christianity" and they leaped to the conclusion that they had found a fresh and living way which would spread and become a world-Christianity. In this faith they undertook "the hazards and hardships" of propagating it, not only at home but "overseas" as well.

The earliest Quaker messengers to reach the American continent were two women, Ann Austin and Mary Fisher, who landed in Boston in July, 1656 , though " the seed of Truth," as the Quakers called their message, was planted at a period almost as early on Long Island and on the shores of Maryland. The Massachusetts officials took excessive care that the inhabitants of their colony should not be harmed or corrupted by these emissaries, and they were soon sent back to Barbadoes, from which island they had come. The messengers who finally succeeded in planting the "seed" in New England were eleven Friends who came over in the ship "Woodhouse" in I657. Their first successful groups were formed in Newport, Rhode Island, and in Sandwich and Salem, Massachusetts, and gradually in the face of great opposition the movement spread through all the New England colonial settlements except those in Connecticut.

The officials of Massachusetts determined to protect their colony from the "invasion" and they adopted the most stringent methods of dealing with what seemed to them a religious peril. Four Quakers were executed, excessive fines were imposed, and a system of "frightfulness" was put into operation in the shape of unmerciful whippings. It was all in vain. The movement grew and increased, as though it fed on persecution, and the authorities were finally led to grant their unwelcome visitors a more peaceful re- 
ception. By the year I 700, the Quakers had become very numerous in New England and they continued to be a growing body until after the period of the Revolutionary War. During the nineteenth century they slowly declined, and they now have a membership of about four thousand in the New England States. There are in all about one hundred and twenty-five thousand Quakers in America and about twenty-three thousand in Great Britain and Ireland.

The following chapter is an attempt to give the reader an impression of the Quaker type of Christianity not so much in its external form and appearance as from the inside and as a living, operating, spiritual and social force.

There are two types of religious leaders, both of whom have played great rôles in history, though I do not mean to imply that they can be divided off from one another by any absolute gap, like that which separates the sheep from the goats. There are, in the first group, leaders who are pledged and dedicated to remote ideals, that is to say, to ideals which seem for the moment unattainable and utopian, and who nevertheless utterly refuse to scale their ideal down or to compromise for the sake of quick but partial gains. By the inspiration and kindling of earlier prophets, or by what Emerson calls "stricter obedience to celestial currents," the leader of this first type sees through the complex and tangle of events and situations and seizes a truth which all men in some happier and more golden age will recognize as true. When he has once seen it, this vision transforms all his ideas and strivings and aims. It spoils forever for him all lower attainments, all half truths, all gains which must be won through the barter or surrender of a possible better. $\mathrm{He}$ will be obedient to that vision regardless of all cost. $\mathrm{He}$ will bear witness to the full light which he has seen, even though he can compel nobody else in the heedless world of 
his generation to see it. He may only cry in the wilderness, but at all events he will cry, and he will proclaim that highest thing his heart knows.

There are, in the second group, the great practical leaders whose eyes are always focussed on results. They understand their age and they know for what it is ripe and ready. They anticipate what the rest about them are incipiently thinking and they voice and interpret the movings and strivings of the rank and file. They know by a kind of instinct how far their contemporaries can be carried and they will not overhurry, they will not outrun the speed of those whom they propose to bring along and they will make graceful bends and curves and wide detours round the obstacles that lie between them and the goal. If they cannot get all they want, they will at least get something.

Both of these methods have proved effective in history, and they are both types of leadership which have won the "well-done" of after ages, and, I believe, the "well-done" of the divine Spectator of events. We must not underrate leaders who do not immediately march straight across country to Canaan the moment they glimpse it from some Pisgah, but who with patient struggle and with much give and take on the road, succeed in bringing the multitude a little nearer to a promised land and in firing them all with a hope of Canaan some day. Hosea Biglow has some wise words on this point:

Theory thinks Fact a pretty thing, An' wants the banns read right ensuin'; But Fact wont nowise wear the ring 'Thout years o' settin' up an wooin'.

The Quakers, however, who came to New England in the mid-seventeenth century belonged to my first type. They had a kind of click of certainty in their souls, which sent them 
forward without any reserves or doubts, without any ifs or buts, without halting reflections or sub-conscious inhibitions. Their leadings were accepted once for all as divine calls and intimations and, that point being settled, they could not do otherwise than follow where their inner star took them. This infallibility of conviction brings with it peculiar difficulties and handicaps and it produces a type of character that seems to others narrow and stubborn, but this note of the "fiery positive" adds immensely to the driving force of a movement, and in the case of the Quakers it brought a fresh element of intensity and of daring venture into the religious life of New England.

About the last thing any self-respecting Englishman of the seventeenth century would have dreamed of would have been such a radical reconstruction of the Christian Church as to put women on precisely the same level as men, and to wipe out all sex-distinction in matters of religion. Just this innovation the Quakers actually made.

The serious attempt to constitute the church of both men and women and to give to women all the spiritual privileges, rights, duties, and functions which belonged to men had once before been tried in the history of Christianity. The Montanists of the second and third century, possessed with enthusiasm for the restoration of prophecy, and for the formation of a church guided by prophets rather than one governed by bishops, threw the door wide open for women; proposed a type of church in which both sexes shared alike and, not only in theory but in practice as well, raised women to the full spiritual stature of men. While this Sibylline movement was at its height women prophesied, taught, baptized, consecrated the Eucharist, and had all the privileges of martyrdom and sainthood, as that extraordinary document, The Passion of Saint Perpetua, vividly shows. But this movement was ruthlessly stamped out, and the 
church which was to do the work of the Middle Ages was so organized that not only was no woman eligible to office or position in the hierarchy, but no man even, who was married, could share in it.

The Reformation swept away the celibate priesthood and wiped out the convent within the Protestant domain, but it left the church severely masculine in all its higher activities and functions. Even if they had desired to make the innovation and constitute the reformed churches of both men and women, the reformers with their conception of the infallibility of Scripture would have been confronted with the impasse of St. Paul's words: "Let the women keep silence in the churches, for it is not permitted them to speak. If they would learn anything let them ask their husbands at home."

The Quakers did not discuss the woman problem; they made no announcement of principles or of programme, but they inaugurated a movement in which from the very first the agelong discrimination against women was entirely absent. Here is an entry in Fox's Journal for the year I667: "I advised the setting up of a girls' school at Shacklewell, for instructing them in whatsoever things are civil and useful in creation." And as the Quaker movement made progress and developed, there came into existence a church organization in which personality, gifts, and specific qualifications were the only tests of fitness for service - the divine right, not of kings and not of bishops, but of common men and women was here recognized and quietly practiced. And once again women had all the privileges of martyrdom, as the story of Mary Dyer grimly illustrates.

The most striking trait of the Quakerism which came as an unwelcome invasion of New England was its emphasis on experience - what William James called " inwardness." Boston had already, in 1636 and 1637 , had its peace of mind disturbed by an exhibition of this type of religion in the 
persons of Anne Hutchinson and her friends, who claimed to have got beyond "the covenant of works" and to have come, with comfort and joy, into "the covenant of grace." These early enthusiasts insisted that other Christians were bound in the strait-jacket of legalism, while they had found their freedom and had entered into an immediate contact with the wells of truth and were aware of the direct bubblings of life in their own souls. This mystical element of religion, which was well-nigh stamped out in the vigorous suppression of the Hutchinsonians, the Quakers revived and re-incarnated wherever they planted their meetings. Quaker mysticism was, however, quite unlike that expounded in the mystical classics, such as the writings of Dionysius, of Eckhart and Tauler and the two golden books: "German Theology" and "The Imitation of Christ." The Quakers were very weak in metaphysics. They had no philosophical passion for absolute unity. They were not perplexed by the problem of multiplicity. They took the world quite naïvely as their senses found it, and, in a general way, their God was the God of religion rather than the God of metaphysics or theology. They discovered something in their own soul, in their own inner consciousness, which seemed not of themselves, nor of man. When they returned home, as they put it, to the shekinah in their own deeps, they felt with awe that they were covered by a living presence and brought into first hand, experimental, relation with the Root and Ground of all true Life. One of these men, who was martyred on Boston Common for his faith, in much simplicity declared that he found himself filled immediately with Life and Power and heavenly Love from that presence which did " mightily overshadow me," and another one of them, who, likewise, was faithful unto death, has left his personal testimony: "I was filled with the Love and Presence of the living God which did ravish my heart when I felt it; for it did increase 
and abound in me like a living stream." They knew very little psychology, and they furnish us no profound analyses of their experiences, as St. Augustine has done of his, but there is directness and sincerity and honesty and restraint in their accounts which make one sure that something dynamic and transforming came into their lives, something that raised them out of the ordinary level, something which made the reality of God absolutely sun-clear to them. They called their experience "the birth of the immortal Seed," or " the birth of God," or " the birth of Christ " in their souls. And they swung out into the full faith that the God who as Spirit brooded like a mother-dove over the vast waste of chaos, and brought a world to birth, had now again in love brooded over their own souls and brought His spiritual Life to birth in themselves. God, then, was no longer worlds of space away, sundered by a bridgeless chasm from man. He was as near as the dew to the grass or the sunlight to the flower, or as the truth is to the mind that knows it. The means of communication between God and man was in their thought no longer limited and confined to an ancient revelation which was miraculously sent across the chasm. The human heart is always oracular and revelation is a fact of all ages and of all lands for obedient souls that have come home to the holy place within. Not once alone, by a stupendous interruption of the processes of his world, did God bring forth his Son, but rather the bringing forth of his Son is the unending and eternal spiritual event of human history and is occurring wherever men let the divine Life have its way unhindered in them. Revelation in Scripture was to these Quakers revelation indeed, but, wonderful as it was, it only indicated what man was capable of, and was thus a guarantee and prophecy of the breaking forth of more light through the ages. Christ was for them God personally revealed and in Him they reverently beheld the union of God 
and man, but this triumphant fact of Galilee carried with it for them the immense implication that God and man were of such a nature that they belonged together and that God could always and everywhere pour his Life into man if man said yes and did his part toward the companionship. Primarily this faith rested upon and grew out of experience, and it was dynamic faith only so long as it was rooted and grounded in living experience of this mystical type. When it was translated into the patois of controversial tracts and hardened down into a static theory of the inward Light, it became, like the shorn and shaven Samson, weak and ineffectual for battle purposes. A dogma asserted in a book is no match for an experience alive and throbbing in a man, and Quakerism lost its marching power in proportion as it dropped from its stage of inward mystical vision to a paper stage of assertion about an abstract principle.

One of the boldest of the experiments which the Quakers made was their creation of a new type of meeting for worship. Convinced as they were by their own living experience that God is an environing Spirit and near of access to our finite spirits, they leaped to the conclusion that the main function of worship is direct communion with God. If so, it cannot be done by one person for another. As the attainment of culture, or taste, or technical skill requires long and patient effort, so communion with God calls for personal preparation of soul, for practice of the presence of God, and for the slow cultivation of the inner eye and ear. If the end to be sought in religion is the acquisition of a set of views and beliefs, or the intellectual mastery of an ancient revelation, then the sermon becomes a necessary instrument, and the centrepiece in the order of divine service will be a logical and persuasive interpretation of doctrine. The congregation will "gather round" the expert minister who speaks for them and to whose word they listen. The Quaker thought 
little, probably too little, of interpretation. The possibility of direct experience, of new revelation, of immediate communion, seemed to him so paramount over everything else in the world that he builded his entire congregational gathering round that. The meeting was not held in order that those present might hear a sermon, however freighted with truth; it was held in order that men and women might bring their lives into conscious fellowship with God and find the living streams of the eternal fountain of Life flowing in their own spirits. They hit upon group-silence as the fittest psychological climate for communion, and with no appeal of any kind to outward sense and with nothing to direct thought or focus attention they came from their widely scattered homes and sat down in solemn hush, positively expectant. Some few of them went off into an unmoved quiet and verified the words of the psalmist: "He giveth his beloved sleep." Others let their minds wander as they listed and experienced the usual zigzags of the flight of unguided association. But the inner " remnant" concentrated and centred down into a contemplation that was intensely active, and marked by strong emotion. For them the silence was like pauses in music during which no notes are sounded and yet the power and significance of the musical piece, far from being interrupted, are gathering depth and volume for a new and intensified burst of harmony. They knew not how it worked, but by a subtle telepathy, which they neither named nor understood, the corporate presence of all helped each to reach a deeper stratum than the superficial one of every day pursuits, and the concentrated aspiration and upward yearning somehow took the soul of the worshipper out beyond its usual margin where it felt refreshed and fed with the water and bread of life.

Quite naturally this exercise - with its stern requirements - did not appeal to everybody. The group was bound to 
be small and select and specialized. Only those who had formed inward habits of concentration, who could leave the affairs of time and space where they belonged and could attain an intensified and heightened hush found the Quaker method of worship of much value. To the undisciplined and lazy soul the silence dragged along in almost unendurable tedium. To the sensitive spirit, inwardly eager and alert, and ready to pay the full cost of direct fellowship with God, there came an abiding spiritual fecundity. It consequently became necessary for the Quakers to propagate their religion very largely through persons who had acquired a peculiar aptitude and habit of mind, and in the eighteenth and nineteenth centuries they were naturally compelled to depend largely upon their own offspring for the Quaker " apostolic succession." The children were taken to meeting from their earliest years. Twice each week they sat in the stillness with their elders and experienced whatever power was there to be felt. The habit of sitting still was formed almost as early as the dawning of a consciousness of self. The expectant attitude of the group, the corporate faith that God was to be found within had a silent but no less effective sub-conscious influence upon the little people whose feet dangled below the hard bench. Every meal at home was preceded by a pause of silence and though little was said in explanation some sense of fellowship with God was associated with the custom. The morning meal was always followed regardless of what occupations pressed - by a solemn Scripture reading and by a period of silent worship during which in some subtle way the life of the united family was lifted up and linked into the enveloping Life of God, so that the children came very early to assume and feel that God was a living and organic part of their family. The approved books which were read aloud in the evening and from which the children in some measure formed their religious ideas 
were journals and biographies of Quaker worthies who had kept the faith and suffered for their truth. This simple genre literature worked in the same direction as the meetings and the family "sittings" did, and helped to repeat and propagate the Quaker type.

The meetings for worship, however, were by no means wholly silent. The silence was not thought of as an end in itself. It was practiced, like a sacrament, as a means of communion and fellowship, and it was done in confident expectation that one or more of the group would be brought up into spiritual fecundity and be moved to offer a prayer which would voice the corporate need of the meeting or to utter a message which would express the word of God for the occasion. All true ministry, according to the prevailing Quaker theory, was prophetic utterance. I do not mean, of course, that the speaker foretold events, but rather that he or she - for there was no distinction of sexes - spoke as a divine messenger and under a preparation and anointing from above. This " ministry of unction" was not primarily the interpretation of Scripture, but it was rather the revelation of fresh and present truth. It was not a logical discourse linked up with therefores and wherefores, nor did it bear the marks of study. It was fused with emotion, somewhat rhythmic, strongly tinctured with biblical style and phraseology, loosely knit and illustrative of sub-conscious processes of association, but at its best vital and pentecostal. It avoided doctrine, but it opened out the meaning of life and made duty and obedience the everlasting things by which men live. The best thing about this ministry perhaps was the conviction which it produced that the God who equipped David long ago for his tasks and who met Saul the persecutor in the way and turned him into a mighty apostolic instrument, was still revealing Himself through men. Without any theological training whatever, and without 
any homiletic skill, the Quaker ministers somehow succeeded in drawing upon their accumulated stock of spiritual experience and, in favored moments, they succeeded in reaching even higher sources of grace, so that they often refreshed their listeners and sometimes made God seem very real and near at hand. The meeting for worship was thus a practical experiment in group-mysticism and in lay-religion, completely freed from ecclesiasticism and ritual.

The Quaker method of pastoral care of the flock was another novel experiment. For centuries the pastoral care of the flock in the church and the moral oversight of its members had been assigned in the main to the local minister in each parish. He had a double mission laid upon him, to expound the gospel as preacher and to shepherd the flock as pastor. The Friends had no such cure of souls in their system. They had, as we have seen, no one in their local meetings set apart to do the preaching. It was the business of the corporate group, under the guidance of the Spirit, to produce its ministry out of its own abounding spiritual life. And so, too, it was assumed that a local church, without any specialized shepherd, would as a corporate body minister to the daily moral and spiritual life of those who composed the group. Gradually it appeared that this plan pushed the democratic ideal quite too far and for the sake of practical efficiency a differentiated band of overseeing Friends had this care of the flock definitely laid upon them about the middle of the eighteenth century. They were called Overseers. They took up the task in that spirit of devotion and with that sacred sense of responsibility which have always been the characteristic source of strength in the Quaker movement. These overseers were for the most part ordinary men and women, like the rest of the group, without any special training, gifted only in good common sense, in balance and poise of character, in the elemental human 
qualities which breed trust and confidence, and endowed of course, as all Friends were in this period, with an unquestioning faith in divine inward help and illumination for their assistance. They proved to be, through the succeeding generations following their appointment, a source of real spiritual strength and of moral control to the numerous groups in which they quietly, unostentatiously labored, and their ministry of discipline and of counsel saved many from breaking anchor and drifting on the rocks. The Overseers were, like conscience among primitive peoples, negative in their scope. They dealt adequately with deviations from "good order" and were quick to discover when one of the flock was going astray, but they were not quite so wide awake to the greater possibilities of positive leadership as they should have been and they did not as fully realize the importance of convicting men of righteousness or of attracting them toward goodness as one could wish. But the period I am dealing with was in all walks of life strongly legalistic in its temper, and the principle of restraint suited the ideals of the time better than did the higher principle of moral contagion.

It is also true that these moral guardians of the flock very often confounded moral issues with their own peculiar notions of piety. What they called " simplicity" or "plainness" came to bulk in their minds as a matter equally big in importance with the moral imperatives. To be "plain" or "simple" meant to dress in the approved garb of the society; to use singular pronouns, "thou," "thee," and " thy," to a single person; to discard titles such as "Mr." and "Mrs." and all unnecessary or insincere compliments; to shun worldly forms of amusement; to forego music; to keep free of entangling alliances of marriage with any person of the world, that is, with one not a Friend, and to avoid business occupations or social relations which involved a 
strain on consistency to the Quaker ideals. After all these things, which we should now perhaps call "ceremonial," the argus-eyed Overseers were supposed to look, and they were expected to report whether the flock was "clear" or " not-clear," but they did not stop with the ceremonial; they went the full way on and endeavored to keep the membership to pure, clean, holy lives.

For the practical accomplishment of their tasks the overseers had an interesting set of "Queries" which formed a kind of moral measuring rod that was frequently applied to the lives of the members. The New England Queries were as follows:

I. Are all meetings for religious worship and discipline duly attended? Is the hour observed? And are friends preserved from sleeping, and all other unbecoming behavior therein ?

2. Are love and unity maintained among you? Is detraction guarded against? And where any differences arise, are endeavors used speedily to end them?

3. Are friends careful to bring up those under their direction in plainness of speech, behavior, and apparel ? To restrain them from reading pernicious books, and from the corrupt conversation of the world ? Are they good examples herein themselves? And are the Holy Scriptures frequently read in their families?

4. Are friends careful to avoid the use of spirituous liquors, except for medicine? The unnecessary frequenting of taverns, and places of public resort? And to keep in true moderation and temperance, on the account of births, marriages, burials, and on other occasions?

5. Are the circumstances of the poor, and of such as appear likely to need assistance, duly inspected, and their necessities relieved, or they assisted in such business as they are capable of ? Do their children freely partake of learning, to fit them for business? And are they, and other friends' children, placed among friends ?

6. Are parents and heads of families, with the young and unmarried, careful that all proceedings with respect to marriage be conformable to our discipline?

7. Do you maintain a faithful testimony against the payment of priests' wages, bearing arms, training, or other military matters? 
Against being concerned in property taken in war, buying or vending goods suspected to be run, and against making false entries, to evade the payment of duties?

8. Are friends careful to inspect their affairs and settle their accounts? Are they punctual to their promises, and just in the payment of their debts, and careful to live within the bounds of their circumstances?

9. Are friends careful to have all their marriages, births, deaths, and burials duly recorded? Are there any friends removed from, or come amongst you, without certificates?

Io. Do you take due care regularly to deal with all offenders, in the spirit of meekness and wisdom, without partiality or unnecessary delay ? And is judgment placed where it appears necessary, in the authority of truth, according to our Discipline?

These Queries were read, in whole or in part, four times in the Preparative Meeting, four times in the Monthly Meeting, four times in the Quarterly Meeting, and once in Yearly Meeting, so that a good Friend was exposed to them thirteen times in a year. A solemn hush followed the reading of them, and each member was given an opportunity to enter into a private confessional under the all-seeing Eye, and he could search his soul as with a candle to see whether he himself was "clear." Then once a year in all the successive meetings carefully prepared answers were read, discussed, and summarized as a digest of "the state of the Society." This periodic reëxamination of conduct and spirit had a profound sub-conscious effect and wove certain community ideals into the very inner substance and texture of the members. It was obviously enough a system of narrow piety. It missed much of what forms the sub-soil of our present day social aspirations, but it was admirably adapted for the cultivation of a type of simple unreflective goodness and it produced beyond question very acute individual consciences.

There was a strong puritanic tincture in the religion of the New England Quakers throughout their history. They 
were, as I have said, uncompromising. They had a deepseated fear of the contaminations of the world. They often favored restraints and indulged in negations, and they were bent on a root and branch extermination of all marks of superstition and apostacy, which had, they believed, crept into the Church. They were, therefore, always in danger of forming a hard, stern type of person, oversatisfied with his own righteousness, critical of that of others. Compelled more or less to withdraw and contract in order to guard their consistency, it was easy for them to grow uncouth in manner and sour in temper. But something almost the opposite happened. As John Woolman puts it, "some glances of real beauty might be seen in their faces." We New Englanders have always been chary of the word "saint," and we instinctively leave all fixing of "calendars" to the powers above, but there was in the best Quaker characters, of both men and women, a fine mingling of strength and humility, a union of rigorous application of judgment to oneself with tenderness for others, a palpitating fear of sin joined with immense confidence in the forgiving love of God. The best specimens, even in the backwoods meetings, revealed a refined and sublimated nature, not only sweet and fragrant, but often radiant and full of grace. They were, best of all, unconscious of the shine on their faces, and those who had the clearest marks of triumphant goodness were the ones who were making the most unrelenting fight with the subtle sins of which only a near-saint knows. The Quaker poet Whittier, who himself was a consummate illustration of the type, has given us a very happy description of one of these everyday saints:

And if her life small leisure found

For feasting ear and eye, And Pleasure, on her daily round,

She passed unpausing by, 
Yet with her went a secret sense

Of all things sweet and fair, And Beauty's gracious providence Refreshed her unaware.

She kept her line of rectitude With love's unconscious ease; Her kindly instincts understood All gentle courtesies.

An inborn charm of graciousness

Made sweet her smile and tone, And glorified her farm-wife dress

With beauty not its own.

The dear Lord's best interpreters

Are humble human souls;

The Gospel of a life like hers

Is more than books or scrolls.

From scheme and creed the light goes out,

The saintly fact survives;

The blessed Master none can doubt

Revealed in holy lives.

I come, finally, to a brief consideration of the ideas which formed, as William James would say, "the keel and backbone" of the Quaker faith. The religious ideas to which I now refer were for most Friends implicit and presupposed rather than reflectively matured. They were, like the mathematics of the spider and the honeybee, woven into the fabric of daily life rather than consciously envisaged or explicitly formulated. If you asked a Friend what he believed, he replied that he would lend the inquirer a copy of Barclay's Apology. It is, however, quite possible to discover by the help of printed sermons, annual Epistles, biographical Journals, and the survivals of personal memory, what formed the living marrow of the faith of these untheological Christians of a previous generation. 
The primary idea, the spring of their religion, was profound belief in a living, present, near-at-hand, environing God, who has dealings now with the souls of men, and is carrying on in the world today, as of old in Galilee and Judaea, his revealing and his redemptive work. The Christrevelation was possible and was genuinely real just because God is inherently in nature and character a Person who can come into intimate contact and relationship with menbecause he is an Immanuel God. The unbroken and continuous work of the divine Spirit through the ages - even ages that were dark - is also possible and is also genuinely real, because God is as essentially self-revealing as is the mid-day sun.

With this root idea was linked also an idea implied in it, namely, that man was somehow kindred with God and always and everywhere a recipient of divine love. They knew that he was sadly damaged and strangely complicated with sinful tendencies, but they still insisted that he was made for fellowship with God, and that he bore in the very structure of his soul a point of junction with the eternal, and was always within reach of home and Father. If any soul lived in the dark his eclipse was an eclipse which he himself made, for the divine sunlight is unsetting and never withdrawn. They did not anticipate the evolutionary view and were loyal to the story in Genesis, but they could not adopt the miserabilism of a ruined world and a ruined man. Somehow God was here and somehow he was operating in the soul as an unsundered and undefeated presence.

Salvation for them, again, was not a forensic scheme. It was a process of life, culminating triumphantly. The most penetrating and adequate account of it which any ancient New England Quaker gave is that expressed in the eighteenth century writings of a fine old Quaker itinerant minister of Rhode Island, Job Scott. Scott's view is the prevailing 
Quaker idea. To be saved is to be inwardly washed and cleansed and brought into vital relation with the divine resources of life. Until "the old man with his deeds" is dead, until the love of sin is conquered by a higher love, salvation has not come to pass, " however one may boast of imputed righteousness and cry peace, peace." Christ himself, that is, the divine nature, must be born and formed in the soul. There must be a death to sin and a rising in newness of life, and the Christian who is to walk with the saved must be ready to go the whole way with Christ, both in suffering and in joy, until grace and truth have their complete and triumphant work in him.

But the Quakers, in spite of their seeming individualism, were always, at least implicitly and in practice, dedicated to a social ideal. Their worship involved a social group. Their meetings for the care of the church were extremely democratic and yet all business was done in unity or not at all. They believed in the divine possibilities of all men and women. In their visions and ideals for the race they saw, dimly perhaps and in the mist, but yet they saw a kingdom of God - a real world of men - divinely changed and inwardly assisted, living in peace, living in love, living in positive coöperation, and exhibiting in this earthly life the traits and the spirit of the eternal City of God.

They were, as I have been indicating, a mystical people, intent upon realizing what William James has called "a religion of veracity rooted in spiritual inwardness," but they were fully as much absorbed in the problem of human betterment, in the task of remaking the social world, as they were in getting their own inward peace. They fully shared the practical spirit of their interesting contemporary, the famous "Digger," Gerard Winstanley. Winstanley in one of his remarkable tracts wrote: "My mind was not at rest because nothing was acted; and thoughts ran in me that 
words and writings were all nothing and must die; for action is the life of all and if thou dost not act thou dost nothing." For them, to see an idea, to discover a truth, was to practice it and put it into play.

Even the Quaker peculiarities were, in inception, an expression of their desire for social reform. They said " thee" and "thou" to everybody because it was the prevailing custom then to say "you" to important persons, upper class people, and "thou" to the common man, and they resolved to wipe out the distinction between upper person and lower person and to maintain one standard of address for man as man. Their odd "testimonies," as they called them, which in time became more or less devoid of significance and hardly more than badges of a peculiar people, were in their origin protests against sham and hollowness, against customs and forms of etiquette which were a burden to the life and which buried the person under a rubbish of meaningless mannerisms, or under the weary weight of stupid fashions. They refused to take a judicial oath because they maintained that there should be only one standard of truthtelling, - to make one's plain word on all occasions as heavy as an oath. They took the idealist or utopian position that war must be utterly abolished in the interest of human rights, and that every form of capital punishment must cease, and that too at a time when it was inflicted for more than two hundred offences.

They did not so much think these conclusions out as feel their way to them, somewhat as Tolstoy has described, in his "Confessions," his own conclusion on seeing a man executed: "I understood, not with my mind, but with my whole being, that no theory of the reasonableness of any present progress can justify this deed; and that though everybody from the creation of the world, on whatever theory, had held it to be necessary, I knew it to be unneces- 
sary and bad." Exactly thus the Quakers felt and feel about taking life in any form or for any reason.

They attacked not only the savagery of the criminal code, but the barbaric prison as well, urging, often to a heedless world, that prisons should be for correction and reformation, not for vengeance. The Quakers took care of their own poor and they endeavored to create a new social conscience toward poverty and the public responsibility for it, which found its finest expression in the Quaker saint of the eighteenth century, John Woolman. They were the prime movers in the establishment of what was in the seventeenth century the novel custom of having a single, fixed, price for goods and merchandise, and they became, from the beginning of their career, champions of the less favored races and of the man who, for any reason, was hampered or handicapped.

They had advanced ideas of the rights of the people to govern themselves and they worked out these ideas on a large scale in colonial America. In Rhode Island the Quakers held the governorship for thirty-six terms and for more than a hundred years they formed a leading influence in the political affairs of the colony. They founded Pennsylvania and shaped its development until the stormy period of the French and Indian wars. They held the proprietorship of New Jersey and governed it until it became a royal colony. Many of their members were in office in Maryland, and under the governorship of the famous Quaker, John Archdale, they profoundly shaped the political development of the Carolinas.

But while they have thus, like John the Baptist, been forerunners in great causes and have been loud voices crying in the wilderness, they have not known how to grow and expand with the growing world. They have shown a tendency to be over-interested in themselves, to spend their energies on the preservation of their own peculiarities and 
to treat their discoveries as "sacred principles" to be held and guarded rather than as truths to be propagated and risked in the stern siftings of evolving society. If they once more return to the robust spirit of their founders and gain again the braver temper of these early innovators they may have even yet a new era of life. 



\section{THE EPISCOPALIANS}

GEORGE HODGES 



\section{THE EPISCOPALIANS}

\section{BEFORE THE AMERICAN REVOLUTION}

$7 \mathrm{HE}$ first Episcopalians who appeared in New England

1 came as members of unsuccessful expeditions. In these undertakings the prime mover was Sir Ferdinando Gorges, commander of the port of Plymouth.

In I605, George Weymouth had explored the Kennebec River for forty miles, had set up a cross as a mark of possession, and had carried away with him several kidnapped natives. These Indians had been taken into Sir Ferdinando's household, and their enthusiastic descriptions of their native land had impressed him greatly. In 1607, an attempt was made at permanent colonization. Settlers were sent over who found Weymouth's cross, and on the spot thus consecrated a religious service was held by Sir Richard Seymour, who was to be the chaplain of the colony. This was the first service conducted by any English minister of religion within the territory now called New England. The plans of the settlers were defeated, however, by frost and fire. In the midst of an uncommonly cold winter their houses were burned, and they set sail for home.

Sir Ferdinando, undiscouraged, undertook presently a larger enterprise. In 1620 , King James graciously presented to him and other patentees the entire coast of New England from Narragansett to the Bay of Fundy. The company who came to take possession of this territory were concerned not only in the better establishment and regulation of trade but in "the advancement of religion in those desert parts." They had a missionary purpose. Being good churchmen, 
they intended not only to enjoy the privileges of religion, but to admit to these privileges their new neighbors, the Indians. They entered New England in the name not only of the crown but of the church. Thus, with Robert Gorges, Sir Ferdinando's youngest son, the commander of the expedition, came the Rev. William Morell, to whom was committed, "I know not," says Bradford, "what power and authority of superintendancie over the churches, and sundry instructions for that end." It was a matter in which the religious community already existing at Plymouth was naturally interested.

The Massachusetts expedition, however, like its predecessor in Maine, failed. Gorges with most of his followers returned to England. But Morell continued on for the space of a year. He was a very quiet gentleman, and showed no disposition to assert his powers of episcopal supervision. Indeed, it was only at the time when he finally went to Plymouth to take passage from that port to London that he informed the brethren as to the nature of his original errand. Meanwhile, he employed what he called his " melancholy leisures" in writing a poem in Latin hexameters and translating it into English verse. This was printed in London, on his return in 1625 , under the title, "New England, or A Briefe Ennaration of the Ayre, Earth, Water, Fish, and Fowles of that Country. With a Description of the Natures, Orders, Habits, and Religion of the Natives." Bradford says that he never showed his authority, or made any use of it, because " it should seeme he saw it was in vaine."

Two of Morell's friends still remained and spent the rest of their lives in New England. When the Puritans came over from Salem in 1629 to begin the settlement of Charlestown, they found Samuel Maverick proprietor of Noddle's Island, or Chelsea, and William Blackstone proprietor of the three mountains and other lands adjacent, now covered by the city of Boston. 
They said of Maverick that he was " a man of loving and courteous behaviour, very ready to entertaine strangers, yet an enemy to the reformation in hand, being strong for the lordly prelatical power." Although a layman he seems to have been a stouter and much more aggressive churchman than his clerical neighbor the Rev. William Blackstone, who may have been intended as assistant to Mr. Morell had the plans of the colony been carried out, and who was quite as unobtrusive a person as his chief, and quite as unregardful of his duty to convert the Indians or the Puritans. His famous saying, "I have come from England because I did not like the lord bishops, but I cannot join with you because I would not be under the lord brethren," indicates his place in the ascending and descending scale of churchmanship. He was content to live beside his spring of clear water, in the midst of his green farm, watching the progress of the fruit trees which he had planted. It is said that afterwards, in the Providence Plantations, "near to Master Williams, but far from his opinions," he resumed the exercise of his ministry; but the name "Study Hill" which he gave to his new residence, in what is now Lonsdale, R. I., shows the direction of his real interests.

Two other early Christians of the Episcopal sort in New England were not only equally lacking in any definite contribution to religion in these parts, but rather contributed so their Puritan neighbors said - to irreligion.

Already, in 1622, Thomas Morton had established himself with a little congenial company at Merrymount, in the present town of Quincy. There he combined the custom of reading the prayers according to the rubrics of the church with a manner of life which displeased and alarmed his more sober neighbors. He was even more frank than Blackstone in expressing his opinion of Puritans; he preferred Indians. "I found two sorts of people," he says, " the one Christians, 
the other infidels; these I found most full of humanity, and more friendly than the other." It is no doubt true that Morton was "more addicted to the feasts than to the fasts of the church." He kept Christmas with much festivity, and worshipped - the Puritans said - " the Roman Goddess Flora " by leading his household in a merry dance about a Maypole. But Samuel Maverick found him a "gentleman of good qualitie," and John Fiske says that the accusation brought against him of setting up a "Schoole of athism " was probably "based upon the fact that he used the Book of Common Prayer." He did undoubtedly introduce an element of serious danger into the situation by providing his friends, the natives, with rum and muskets. The combination menaced not only the peace but the very existence of the settlements. Myles Standish came up from Plymouth and dispersed the men of Merrymount. Endicott came over from Salem and cut down the Maypole.

About the same time the Plymouth people were having difficulty nearer home with another churchman, the Rev. John Lyford. He had come over, by the appointment and at the charge of the merchant adventurers who financed the Plymouth Colony, to be the pastor of the congregation. The Plymouth people had desired Robinson of Leyden, but an unfriendly majority sent Lyford in his place. The independence of the parish was so far respected as to leave them free to reject him if they wished. And this seems to have appeared not altogether unlikely. "We have sent you a preacher," said the company, "an honest, plaine man, though none of the most eminente and rare. About choosing him into office use your owne liberty and discretion. He knows he is no officer among you, though perhaps custom and universalitie may make him forget himself." At the same time they sent a carpenter, who, they said, " is thought to be the fittest man for you in all the land, and will no doubt 
doe you much good." They had great confidence in the carpenter.

Under these difficult conditions Mr. Lyford entered upon such duties as devolved upon an Episcopal minister set in charge of a Separatist Congregation. The episcopal elements in the situation he immediately adjusted to the environment by behaving himself, on his first arrival, with " that reverence and humilitie as is seldom to be seen," desiring to join their church, and being received into it after a "large confession of his faith, and an acknowledgement of his former disorderly walking." It was found, however, after a little, that the new pastor, together with John Oldham, who became his close friend, was writing letters to the company filled with criticism of the brethren. The matter was a serious one, for the colony was dependent on the company. And the governor was certain of the guilt of Lyford, having taken the precaution to open and read his letters. It appeared by this correspondence that Lyford and Oldham and other conspirators intended to withdraw from their neighbors and set up a public meeting apart, and, as they expressed it, "have the sacraments." They were accordingly put on trial for schism and sedition, and, with abundant allowance of time whether for repentance or for preparation, were sentenced to expulsion. Bradford says nothing about the use of the Prayer Book as one of their offences, but Morton, in his New English Canaan declares that their essential transgression consisted in their loyalty to the Church. "The booke of common prayer," said their adversaries, "what poore thing is that, for a man to reade in a booke? No, no, good sirs, I would you were neere us, you might receave comfort by instruction - give me a man that hath the guiftes of the spirit, not a booke in his hand."

Lyford and Oldham came up to Naumkeag, where they joined Roger Conant in a scheme for a new settlement of 
which Conant was to be the governor, Lyford the minister, and Oldham the trader with the Indians. But Lyford, in response to "a loving invitation," went to Virginia, where he shortly after died. It was in celebration of the peaceful adjustment of differences between Conant's men and Endicott's men that Naumkeag was called Salem. In 1629 , for the further preservation of this peace, the brothers Brown, Samuel and John, were sent away. The settlers had definitely organized themselves into a Congregational Society, after the pattern of Plymouth. The Browns protested and declared that so far as they were concerned they would continue to use the Book of Common Prayer. They were informed that there was no convenient place in New England for the use of that book, certainly not in Salem. They were put on board the next returning ship, and sent to England.

Meanwhile, the enthusiasm of Sir Ferdinando continued. Leaving for the moment the Puritans of Massachusetts in possession, he secured in 1635 , a grant of the country between the Kennebec and the Merrimac, to which was given the name of Maine. For this province he planned a government, under a royal charter, in which religion was established according to the doctrines and discipline of the Church of England. The Rev. Richard Gibson was the first minister in this district, having his church and parsonage at Portsmouth, N. H. The second minister was the Rev. Robert Jordan of Casco, now called Portland.

This situation, with an Episcopal colony north of the Merrimac and a Puritan colony south of it, was most displeasing to the Puritans, one of whose chief purposes in coming to these shores had been to get as far away as possible from prelatical Episcopalians. It was therefore with much satisfaction that they discovered that the Merrimac, instead of proceeding in a straight line from west to east, had a 
sharp turn in it, and came down out of some unknown region in the north; for the boundary line was described in the charter as three miles north of the Merrimac. Where then did that river begin? Endicott sent men up to find out, and they located the source of the river in Lake Winnepesaukee. There on a convenient rock they cut the name of John Endicott, and their own initials: E. J. for Edward Johnson, who wrote the Wonder-Working Providence of Sion's Saviour, S. W. for Captain Simon Willard. The inscription is legible to this day. Then they measured from a point three miles north straight across the map and thus established the upper boundary of Massachusetts on a line running from Lake Winnepesaukee to Casco Bay. By this ingenious procedure the Puritans by a single motion of a pencil along the edge of a ruler, included within their own lawful possessions practically all of the Episcopal colony that was worth having. That was in $165^{2}$, when the Commonwealth was in power in England. Already Dr. Gibson, for opposing the encroachments of Massachusetts, had been put out of his parish. Mr. Jordan, persisting in the use of the Prayer Book, baptizing children, and using the service of marriage, was several times fined and imprisoned. When he died, in I679, there was no Episcopal minister remaining in the whole territory of New England.

Of course, in a sense, all of the Puritan ministers were Episcopalians. They had been ordained in the Church of England. In the Anglican Communion, then as now, there were two parties; Low Church and High Church. The adjectives indicated the importance which they attached to the Liturgy and to the Episcopate. Under the ill-advised urging of the High Church brethren, led by Archbishop Laud, the Low Church brethren had come to the conviction that the Liturgy and the Episcopate were of no importance 
whatever. They were in the curious position of Episcopalians who disused the Prayer Book and defied the bishops.

Thus, Higginson, taking leave of England, in I629, said, "We will not say, as the separatists were wont to say at their leaving of England, 'Farewell, Babylon! farewell, Rome!' but we will say, Farewell, dear England! farewell, the Church of God in England, and all the Christian friends there! We do not go to New England as separatists from the Church of England; though we cannot but separate from the corruptions of it; but we go to practice the positive part of church reformation, and propagate the gospel in America." And Winthrop said, "We esteem it an honor to call the Church of England, from whence we rise, our dear mother, and cannot part from our native land, where she specially resides, without much sadness of heart and many tears in our eyes. For acknowledging that such hope and faith as we have obtained in the common salvation we have received in her bosom and sucked it from her breasts, we leave it not, therefore, as loathing that milk wherewith we were nourished there; but, blessing God for parentage and education as members of the same God, shall always rejoice in her good, and unfeignedly grieve for any sorrow that shall ever betide her, and, while we draw breath, sincerely desire and endeavor the continuance and abundance of her welfare, with the enlargement of her bounds in the kingdom of Christ Jesus."

These men were churchmen. John Cotton was a churchman; so were Hooker and Shepard. John Harvard was a churchman. The name "Puritan," by which they were called, meant what "Low Churchman " means today, and designated a party not outside the church but within it. That their low-churchmanship, beginning with non-conformity to details which they considered unessential, widened presently into separation, was due in part to the long space of ocean which lay between them and England, and to their 
natural neighborliness with the godly separatists of Plymouth, but still more to the war which embittered the old controversies with the tragedies of battle. It was not Winthrop, nor Higginson, but Charles and Laud who carried the New England Puritans outside the Church of England.

When the Commonwealth and the Protectorate were over, and the crown and the church were together restored in England, the division in religion on these shores was emphasized by the political situation. The Puritan colony of Massachusetts was made a royal province, and in I686, the ship which brought Joseph Dudley to be president of Massachusetts, Maine, and New Hampshire, brought also the Rev. Robert Ratcliffe to conduct the services of the Book of Common Prayer in Boston. Thus came the Church of England in company with the tyranny of the Stuarts.

The Puritans were quite right in identifying the religious with the political situation. Governor Cranfield of New Hampshire had written to England to express his humble opinion, as a churchman, "that it will be absolutely necessary to admit no person into any place of trust, but such as will take the sacrament and are conformable to the rites of the Church of England." This was a proposition to completely reverse the existing order, to disestablish the Puritan theocracy and put the Church of England in the place of it. Cranfield said further, "I utterly despair of any true duty and obedience paid to his Majesty until their college be suppressed and their ministers silenced." The endeavor to put these ideas into effect in New Hampshire had not been successful. But nobody could safely predict the immediate future in Massachusetts.

When, therefore, Judge Sewall wrote in his Diary under date of Sabbath, May 30, I686, "My son reads to me in course the 26 th of Isaiah, and we sing the I4Ist psalm, both exceedingly suited to the day wherein there is to be worship 
according to the Church of England as 'tis called, in the townhouse by countenance of authority," we look for expressions of pious fear and righteous indignation. The Isaiah passage might have been taken by an unprejudiced reader to welcome the advent of true religion: "Open ye the gates, that the righteous nation which keepeth the truth may enter in." But the psalm uttered the emotions of the Puritan soul: "Lord, I cry unto thee, make haste unto me. Incline not my heart to any evil thing, to practice wicked works with men that work iniquity, and let me not eat of their dainties. Our bones are scattered at the grave's mouth, as when one cutteth and cleaveth wood upon the earth. Keep me from the snares which they have laid for me, and the gins of the workers of iniquity. Let the wicked fall into their own nets, whilst that I withal escape."

It was a week later, on June 6 , that the building was actually used for the first time. Application had been made for the use of one of the three meeting-houses, but had been refused, and the service was said in "the library room in the east end of the town-house," on the site of the present building of the Old State House. At the same time wardens were elected, and "Mr. Smith the joiner" was employed to make twelve benches to seat the congregation. In the middle of August the senior warden was asking Judge Sewall for a contribution toward the building of a church, "and seemed to go away displeased," says Sewall, "because I spake not up to it." Meanwhile, we learn from a letter written by Edward Randolph, who was the most zealous churchman in these parts, that the company of the faithful was increasing beyond expectation. They had left the library of the town-house for the Exchange, where they had "Common Prayer and two sermons every Sunday, and at seven o'clock in the morning on Wednesdays and Fridays the whole service of the church." 
In December of that year, Sir Edmund Andros became governor. On the very day of his arrival he asked for a meeting-house in which the church service might be held, suggesting some adjustment of time so that the Episcopalians and the Puritans might use the same building at different hours on the same day. The Puritan ministers met and agreed that they "could not with a good conscience consent that our meeting-house should be made use of for the Common-Prayer worship." Saturday of that week was Christmas Day, and the governor, who had absented himself from the Thursday Lecture, went to the church service twice.

Nothing of further importance happened until Lent. Then on the Tuesday of Holy Week, the governor viewed the three meeting-houses. On Wednesday, he sent Randolph for the key of the South Church. We tell him, says Judge Sewall, " that we can't consent to part with it to such use." No matter; on Good Friday, March 25, 1687, the sexton, "Goodman Needham, though he had resolved to the contrary, was prevailed upon to ring the bell, and open the door at the governor's command." Note is made that Smith the joiner and Hill the shoemaker were "very busy about it." On Easter Day, the Episcopalians met in the South Meetinghouse at eleven, telling the proprietors to come at half-past one, but the service lasted until after two. "'Twas a sad sight," says Sewall, "to see how full the street was with people gazing and moving to and fro, because they had not entrance into the house."

This arrangement was so inconvenient, and served so continually to increase the common enmity against the invading church, that the governor and his council took a corner of the burying-ground and proceeded there to erect another building for their own undivided use. The foundations were laid in October, r688, and the first service in the 
new church was said on Sunday, June 8, r689. Already, however, in England the Restoration had been followed by the Revolution. Out went King James, in came King William. Before the church was completed, Randolph and Andros were expelled; within a month after the first service, the Rev. Robert Ratcliffe prudently returned to England. The enthusiasm of the Puritans exercised itself upon the building, whose windows were broken, and its doors and walls defiled with filth (a contemporary record says), "in the rudest and basest manner imaginable." Thus ended the second chapter in the history of the Episcopalians in New England.

The affiliation of the churchmen with the House of Stuart has obscured the fact that they were contending for religious liberty. It is true that they were of the same temper and disposition as the Puritans themselves and opposed the Puritan uniformity in the hope of establishing an Episcopal uniformity in the place of it. They were thus behind Roger Williams, the Baptist, and William Robinson, the Quaker, who were their partners in substantially the same business; for Williams and Robinson asked only the right to live in Massachusetts in peace. But they were on the general level of their age. Puritans and churchmen agreed in their conscientious insistence on the principle of uniformity in religion. They disagreed in their idea of the religion under whose authority all men must be brought. It is nevertheless a fact that in the history of New England their two negatives made one great affirmative. Randolph and Andros - naturally maligned by their Puritan neighbors but honest and devout gentlemen notwithstanding - dealt a blow against intolerance, under which the whole substance of the Puritan administration staggered. They succeeded, in spite of the Puritans, in building in Boston a church of their own kind, and in securing freedom to worship God in their own way. 
The third attempt of the Episcopalians to cultivate the reluctant soil of New England was directed by the Society for the Propagation of the Gospel in Foreign Parts.

As early as 1649 , a Society for the Propagation of the Gospel in New England had been projected, but the beheading of King Charles and the political and ecclesiastical changes which ensued had prevented its organization. In I66I, King Charles II had incorporated " several persons into one Society or Company for Propagation of the Gospel in New England and parts adjacent in America." The purpose, as set forth in the charter, was to convert the " heathen natives." It was remarked, however, in the same document, that it was " the unhappiness of New England and the adjoining parts to be first planted and inhabited by persons who were generally disaffected to the church by law established in England," and it was felt to be necessary to provide for a "regular and orthodox ministry to be sent and settled among them, to remove those prejudices under which the people generally labored, and to promote, as much as possible, an agreement in faith and worship in order to the recommending our holy religion to unbelievers." As the century came to an end, and further changes in politics suggested further changes in religion, it seemed wise to found a society which should take under its charge the advancement of religion not in New England only, but in other colonies also. The Society for the Propagation of the Gospel in Foreign Parts was accordingly established in I 70I. This society sent over, as a travelling missionary, the Rev. George Keith.

Keith was already acquainted with America, having been a Quaker preacher in Philadelphia. He arrived in Boston in June, $\mathrm{1} 702$, and was kindly received both by the governor and the deputy-governor and by the Rev. Samuel Miles and the Rev. Christopher Bridge, who had succeeded Robert Rat- 
cliffe as minister in charge of what Keith in his Journal calls the Queen's Chapel. There he held forth in a manner which, he says, "did greatly alarm the independent preachers." Increase Mather immediately printed a reply to Keith's sermon, and Keith printed a reply to Mather. On Wednesday, July I, the missionary attended the commencement exercises at Harvard College, and " having heard Mr. Samuel Willard, president of the college, at the said commencement maintain some assertion that seemed to me," he says, "very unsound, the next day I writ a letter to him in Latin, showing my great distaste to those his assertions." Keith printed his letter, Willard printed a reply to Keith, and Keith printed a reply to Willard. In this aggressive manner the representative of the Society began his mission. His chief controversy, however, was with the Quakers, whose errors he knew by personal experience. In Lynn, in Salem, in Hampton, in Dover, then in Newport, and other places in Rhode Island, he appeared in Quaker meetings to the great disturbance of the peace. Thence he went to New York, and to Philadelphia, and even, as he said on the title-page of his Report, to "Caratuck," in North Carolina.

Keith spent two years in this peregrination, calling together the people of the Church of England, holding services according to the Book of Common Prayer, and advising the Society in London as to the places to which they might send regular and orthodox ministers to the best advantage.

The seed thus planted in New England came first to flower and fruit in Rhode Island. The Society sent to Newport the Rev. James Honeyman, allowing to the minister an annual stipend of fifty pounds, and fifteen pounds in addition " towards furnishing and adorning their church with a chalice, patten, cloth for pulpit and communion table, and other ornaments." A church was built then in I702, and in I703 the minister and vestry reported that they were building a 
steeple and enlarging the church by a new gallery. This structure is still standing, as is also the Narragansett Church, erected in I 707. St. Michael's Church was founded in Bristol in I7 I9, and St. John's Church, then called King's Chapel, in Providence, in 1722.

The original seal of the Society showed a ship with sails set arriving at these shores, in the prow a black-gowned parson holding an open Bible, and on the land the heathen natives hastening from all directions with outstretched, welcoming hands. This vision of the conversion of the Indians was never realized. The heathen natives proved to be actively hostile. The work of the Society affected only the English settlers. It consisted in part in giving much-needed financial aid, helping to pay salaries and to build churches; but still more, in providing the new parishes with ministers of good character. The Society was exceedingly careful about the men whom it selected. Their records were examined, testimonials were required from their bishops, excellent suggestions were made as to the details of their grave demeanor, and they were expected to make regular reports of their ministrations. If they laid themselves open to serious complaints from their parishioners or others, they were recalled. Even the manner in which they conducted their inevitable controversies was examined. Mr. John Checkley of Boston was so zealous, animated, and outspoken in his defence of episcopacy that he found it difficult to get a bishop to ordain him.

This high standard of clerical character was still further maintained by a remarkable series of accessions to the ministry of the Episcopalians from the ministry of the Congregationalists and Presbyterians. The first of these converts was the Rev. Timothy Cutler.

In I722, at the close of the commencement exercises of Yale College, the president and faculty requested a confer- 
ence with the trustees, and presented to them an extraordinary statement. "Reverend Gentlemen," they said, " having represented to you the difficulties which we labor under in relation to our continuance out of the visible communion of an Episcopal Church, and a state of seeming opposition thereto, either as private Christians or as officers, and so being insisted on by some of you (after our repeated declarations of it) that we should sum up our case in writing, we do (though with great reluctance, fearing the consequences of it) submit to and comply with it: And signify to you that some of us doubt the validity, and the rest of us are more fully persuaded of the invalidity, of Presbyterian ordination in opposition to Episcopal, and should be heartily thankful to God and man if we may receive from them satisfaction therein, and shall be willing to embrace your good counsels and instructions in relation to this important affair as far as God shall direct and dispose us to do."

This statement was signed by the two gentlemen who then composed the Yale faculty: Cutler, the president, and Daniel Brown, the tutor; and also by five Congregational ministers. President Woolsey, recalling the event on the occasion of the one-hundred-and-fiftieth anniversary of the founding of the college, said, "I suppose that greater alarm would scarcely be awakened now if the theological faculty were to declare for the Church of Rome, avow their belief in transubstantiation, and pray to the Virgin Mary."

The fear of the consequences which the signers frankly confessed was immediately justified. The trustees asked for the resignations of Brown and Cutler, and voted to require of their successors before taking office a declaration of assent to the Saybrook Confession of faith and an assurance of opposition to "prelatical corruptions." Cutler and Brown started at once for England to be ordained, and with them went Samuel Johnson, one of the Congregational 
divines. Brown died of smallpox, the besetting plague of ocean travellers at that time, but his friends returned, Cutler to Boston, Johnson to Stratford in Connecticut. That was in the spring of 1723 .

On the I 5 th of April in that year was laid the corner-stone of Christ Church, Boston, and in September Dr. Cutler became the first rector of that parish. The first service was said in the completed church on the 29th of December. The building remains to this day, in excellent condition, recently restored, the oldest house of worship in the city. In I735, Trinity Church was built in Boston by a parish so financially substantial as to need no aid from the Venerable Society. The Rev. Addington Davenport was the first rector. Peter Faneuil contributed a hundred pounds towards the purchase of an organ.

Already, in I 7 I5, St. Michael's Church had been built in Marblehead. The second rector, the Rev. David Mosson, after a ministry of nine years, removed to Virginia, where he had as a parishioner George Washington, at whose marriage to Mrs. Custis he officiated.

In I7I2, the Society had appointed a minister to take charge of a congregation in Newbury in consequence of a serious division of the Congregationalists concerning the location of a church building. This building having been erected on Pipe-stem Hill, the people who wanted it on "the plains" became Episcopalians.

Meanwhile, the Episcopalians were prospering in Connecticut. It was after the Revolution that President Ezra Stiles of Yale noted in his diary a list of some twenty disquieting signs of the times which, he said, kept him awake at night. One of these he described as " an alarming increase of wickedness and episcopacy." The increase of episcopacy started with Johnson. When he and Brown and Cutler began to read Church of England theology in the library of 
Yale College, there was not an Episcopal minister in the colony. When Johnson settled in Stratford and in I724 completed the building of a church, he was the only clergyman of his order in that part of the country. Then came Henry Caner, of the class of 1724 , whom Johnson instructed in theology, and who afterwards became rector of King's Chapel in Boston. "A love to the Church," wrote Johnson, "gains ground greatly in the college. Several young men that are graduates, and some young ministers, are very uneasy out of the communion of the Church, and some of them seem much disposed to come into her service." Two of these, Pierson and Brown, went to England for ordination. Samuel Seabury, whose son became the first bishop of Connecticut, came in from the Congregational ministry. So did Beach of Watertown, Punderson of Groton, and Bliss of Hartford. Within twenty years from the beginning of Johnson's ministry fourteen churches had been built. Punderson became the first rector of a parish in New Haven, and built a wooden church on the site still occupied, at a time when it was said that the door-sill of the new building was wide enough "to furnish seats for all the men of the Episcopal families in the town."

In I 729, the Episcopal Church in Rhode Island, and throughout the New England colonies, was reinforced by a visit from Dean Berkeley.

George Berkeley, dean of Derry and afterwards bishop of Cloyne, was already a philosopher of eminent distinction. His Principles of Human Knowledge, published in I709, had begun a revolution in speculative science. He had propounded his characteristic theory that nothing exists apart from mind. This theory had not prevented him from forming a conviction of the incalculable importance of the American colonies. He foresaw for these settlements a vaster future than was dreamed of by any of his countrymen. He 
perceived the Star of Empire moving toward the West. Berkeley was so attractive a person that Miss Vanhomrigh, Dean Swift's friend, bequeathed him half her property after meeting him once at dinner. It is not surprising, therefore, that he should have been able to persuade Sir Robert Walpole to look with favor on his plan to found a college in the Bermudas for the benefit of the Americans. Walpole promised a grant of twenty thousand pounds to endow this institution, but suggested that Berkeley would be more likely to get it if he went to America. Eventually, the promise came to nothing, but Berkeley's residence here for two years was productive of great good.

Mr. Honeyman of Newport was in the midst of his sermon on a Sunday morning when word was brought him that the Dean of Derry had arrived, and he came down from the pulpit, closed the service, and led the whole congregation to the landing to meet him. Johnson of Stratford came to consult him concerning the charter of the College of Philadelphia, now the University of Pennsylvania, and concerning the charter of King's College, now Columbia University. Johnson had declined the presidency of the former of these institutions, to which he was nominated by Benjamin Franklin, and had accepted the presidency of the latter. Berkeley's ideas directed the original course of each of these Episcopal foundations. The great immediate value of his residence, however, was in the fact that the Episcopal Church possessed in him a representative whose intellectual distinction and saintly character every Puritan minister in the country recognized.

The next influential churchman to visit these shores was George Whitefield. He came to Boston in I 740 in the time of the Great Awakening.

Jonathan Edwards in Northampton and George Whitefield and John Wesley in London had discovered a new way 
to become a Christian. They had each of them entered into a new consciousness of God and a new assurance of salvation through a psychological experience. Among the factors of this experience were an awful horror of hell, a profound sense of $\sin$, a definite perception of Christ as the Saviour of their individual soul, and a resulting spiritual confidence and joy. They began to lead others along the steps of this experience. The results were astonishing. In a time of general unbelief and unusual indifference to religion they were able to appeal effectively to the conscience of thousands, and to bring them to conviction. The fear of hell which they aroused in their auditors as the beginning of their new treatment of souls, and the certainty of heaven with which the treatment was completed gave rise to scenes of extraordinary emotion. Nothing quite like it had ever taken place among such multitudes.

By a natural process of reasoning, based on the actual results of the method, the preachers of the new way were led to maintain that it was the only way. Not by the sacraments of baptism and the Holy Communion, not by Christian nurture and gradual growth in grace, not by the living of a holy life, were people to enter into the Kingdom of God, but of a sudden, with great violence, through a passionate emotional experience. And presently the leaders did not hesitate to say that nobody was a Christian, no matter how good, no Episcopal clergyman with his Book of Common Prayer, no Puritan minister with his orthodox theology and his austere righteousness of life-nobody was a Christian unless he had passed through this experience of definite conversion.

Whitefield came preaching this new doctrine. He was an ordained minister of the Church of England, but his churchmanship was of a piece with that of the Puritans of the early colonization of Massachusetts who considered the 
liturgy and episcopacy as of no importance. It made no difference to Whitefield where he preached, whether in an Episcopal church or in a Congregational meeting-house, or on Boston Common. All ministers looked alike to him, whether they wore surplices or Geneva gowns. Indeed, he included them all alike under the condemnation of being little better than the heathen unless they had been converted.

Dr. Colman of the Brattle Street Church invited Whitefield to Boston. Dr. Cutler, meeting him in the street, said to him frankly, "I am sorry to see you here"; to which Whitefield replied, "So is the devil." He visited Ipswich, Marblehead, Salem, Newburyport, and Portsmouth, preaching everywhere to vast multitudes. In Cambridge he spoke at the college: "scarce as big," he said, " as one of our least colleges at Oxford " and " not superior in piety." He found the tutors and students reading "bad books"; meaning, as the context shows, the theological works of Archbishop Tillotson. "Boston," he wrote in his journal, "is a large populous place, and very wealthy. It has kept the form up very well, but has lost much of the power of religion." "The pride of life," he said, " is to be seen in their assemblies. Jewels, patches, and gay apparel are commonly worn by the female sex. I observed little boys and girls commonly dressed up in the pride of life, and the infants that were brought to baptism were wrapped up in such finery that one would think they were brought thither to be initiated into, rather than to renounce, the pomps and vanities of this wicked world."

Dr. Cutler described Whitefield's visit, in a letter to a friend:

Whitefield has plagued us with a witness. It would be an endless attempt to describe the scene of confusion and disturbance occasioned by him; the divisions of families, neighborhoods and towns; the con- 
trariety of husbands and wives; the undutifulness of children and servants; the quarrels among the teachers; the disorders of the night; the intermission of labour and business; the neglect of husbandry and the gathering of the harvest. . . . In many communities several preaching, and several exhorting or praying, at the same time, the rest crying, or laughing, yelping, sprawling or fainting. This revel in some places has been maintained many days and nights together.

When Mr. Whitefield first arrived here, the whole town was alarmed. He made his first visit to church on a Friday, and canvassed with many of our clergy together, and belied them, me especially, when he had gone. Being not invited into our pulpits, the Dissenters were highly pleased, and engrossed him; and immediately bells rang, and all hands went to lecture. This show kept on all the while he was here. The town was ever alarmed; the streets were filled with people with coaches and chairs, all for the benefit of that holy man. The conventicles were crowded; but he rather chose the Common, where multitudes might see him in all his awful postures; besides, in one crowded conventicle, six were killed in a fight before he came in; but he ever anathematized the Church of England, and that was enough.

After him came one Tennant, a monster, impudent and noisy, and told them they were all Damned! damned! damned! This charmed them, and, in the most dreadful winter I ever saw, people wallowed in the snow, night and day, for the benefit of his beastly brayings.

That this description was not due to prelatical prejudices appears from a like account given by Dr. Chauncy of the First Church. He says that Whitefield spoke in every sermon about the unconverted ministers, calling them carnal, unregenerate wretches, and enemies of Christ, the worst He had. The people, he adds, were praying, screaming, singing, and jumping up and down, " the whole with a very great noise to be heard at a mile's distance."

The effect of the Great Awakening upon the Episcopal Church was, in part, to set a further separation between the Episcopalians and their pious neighbors. The churchmen held aloof from the revival meetings, and were thought to have no vital piety. At the same time the sobriety of the Episcopal services, and the quietness and general sanity of 
the Episcopal system, attracted into the church considerable numbers of persons whom the methods of the revival preachers had repelled. They were of the mind of the man on whose tombstone in the Copps Hill burying-ground is the inscription: "He was an enemy to enthusiasm," - meaning by "enthusiasm" the unrestrained emotion and the disorderly behaviour of the disciples of Whitefield.

Then the political situation grew every year more tense, and here again the Episcopalians were on the unpopular side. Not all of them - Washington was a churchman, but a good many of them, especially among the clergy. The Church of England was their mother church; they prayed regularly for the King. The representatives of the English government were most of them churchmen. So were many of the landed proprietors, owners of fine houses, as in Cambridge, on Brattle Street, called Tory Row, or Church Row, the adjectives being considered synonymous. The plain people in the pleasant parishes were quite as likely as their Puritan neighbors to cast in their lot with the patriots, but the wardens and their families, and the clergy, linked to England by a thousand ties of association and relationship and affection, were likely to be royalists. On the I8th of April, I775, it was the sexton of Christ Church who hung the lanterns in the tower to direct the midnight ride of Paul Revere. On that very day the rector, the Rev. Mather Byles, Jr., handed in his resignation.

\section{AFTER THE AMERICAN REVOLUTION}

THE benefactions of the Society for the Propagation of the Gospel had been a great help, but also a serious hindrance, to the Episcopal churches of New England. The Society was most generous, and by its assistance buildings were erected and salaries were paid, but the effect was to provide the 
parishes with ministers who had been born and brought up and educated in England, and who were dependent for their living upon the English church. In Connecticut, owing to accessions from the Congregationalists, there was a considerable number of native clergymen, but elsewhere the conditions were such as to connect the Episcopal clergy with England in bonds both of dependence and of affection such as did not exist in any other communion. The liturgy with its prayers for the King laid a further burden on the Episcopal conscience.

The result was that the American Revolution, which affected all the churches, brought the Episcopal Church to the very edge of extinction.

When the war was over only two parishes survived in Maine, one at Gardiner and the other at Portland, and neither of them had a minister.

In New Hampshire there were two parishes, one at Portsmouth, the other at Claremont. The Portsmouth parish had had for its rector the Rev. Arthur Browne, who appeared at the marriage of Lady Wentworth in the Tales of a Wayside Inn. The Claremont parish had been organized by the Rev. Samuel Peters, whose General History of Connecticut contained the famous spurious collection of forty-five Puritan regulations, known as the "Blue Laws." In 1775 , the rector, the Rev. Ranna Cossit, wrote to the Society: "I have constantly kept up public services, without any omissions for the King and royal family and likewise made use of the prayers for the High Court of Parliament and the prayers used in time of war and tumults. The number of my parishioners and communicants in Claremont are increased, but I have been cruelly distressed with fines for refusing entirely to fight against the King. In sundry places where I used to officiate the church are all dwindled away. Some have fled to the King's army for protection, some are banished and 
many are dead." He added, "I have been by the committee confined as prisoner in the town of Claremont since the I 2 th of April, I775; yet God has preserved my life from the rage of the people." That was in I779. In I794 a meeting of the parish was held to "see upon what terms they will join the Congregational people in hiring Mr. Whiting." Mr. Whiting was " to officiate alternately at the church and at the meetinghouse." But this endeavor after Christian unity the Congregational people declined.

In Rhode Island there were four parishes, - Trinity, Newport, St. Paul's, Kingston (the "Narragansett Church"), St. Michael's, Bristol, and St. John's, Providence. The Bristol church was burned by British soldiers. The rector of the Providence church, in July, I776, "was pleased to absent himself from duty, though very earnestly requested to keep up the worship, saying he could not, as prayers for King George were forbidden."

In Massachusetts there were fourteen parishes. But Dr. Caner of King's Chapel, on the occasion of the evacuation of Boston by the British in I776, had fled to Nova Scotia, in company with a considerable part of his congregation. He left a memorandum stating that " an unnatural rebellion of the colonies against his majesty's government obliged the loyal part of his subjects to evacuate their dwellings and substance, and take refuge in Halifax, London, and elsewhere. By which means the public worship at King's Chapel became suspended and is likely to remain so until it shall please God in the course of his Providence, to change the hearts of the rebels, or give success to his majesty's arms for suppressing the rebellion."

In the minute-book of the vestry of Christ Church, Boston, there are two blank pages between the 6th of September, I774, and the 3ist of March, I779. On the second date the rector was desired to prepare a proper form of prayer for 
Congress, for the several states, and for their "success in the present important contest," to be used daily in the church.

Such prayers had been used in Trinity Church, by the Rev. Samuel Parker, during the Revolution, and the parish had been maintained in consequence.

The Rev. East Apthorp had left the pleasant house which he had built for his residence in Cambridge, which his Puritan neighbors called in derision the "bishop's palace," and had gone to England. Christ Church, used for barracks by the Revolutionary soldiers, had been cleared for divine service, at the request of Mrs. Washington, on the last day of $I 775$, but thereafter, until I 790 , stood empty, open to the weather. Only five clergymen were found in Massachusetts in 1787 to sign a protest against the ordination of James Freeman.

In Connecticut, when the Revolution began, there were twenty Episcopal clergymen and forty parishes. At the end of the war there were fourteen clergymen remaining, but in the midst of diminished parishes, and subject to the suspicion and the ill-will of their patriotic neighbors. The church in Fairfield had been destroyed when General Tryon burned the town. The church in New London had suffered a like fate at the hands of Benedict Arnold. The church in Norwalk lay in ashes. Other church buildings had been plundered and defaced, some by British soldiers, some by patriots. Of the clergy, some had fled, some had been imprisoned, some had been mobbed. Mr. Graves of Norwich, persisting in praying for the King, had been "brought expeditiously to the level of the floor." Mr. Beach in the course of a bold sermon against rebellion had been fired at by an aggrieved parishioner; the mark of the bullet is still to be seen in the sounding-board of the church at Redding.

Under these hard conditions the Episcopalians of New England gathered themselves together when the storm of war was past. They were a feeble folk, few in number, 
deprived of the financial assistance on which they had depended, and under suspicion both in religion and in politics. They were commonly considered to have neither piety nor patriotism; having held aloof both from the Great Awakening and from the Revolution. They were held to be the votaries of a foreign religion, which was identified in the general mind with aristocracy, and monarchy, and tyranny, and with malignant opposition to the freedom of the colonies. At a time when almost everybody hated England, these brethren belonged to the Church of England.

And they had no leader. More serious than the distrust and enmity of their neighbors was this radical weakness. In a church called Episcopal because it is administered by bishops, they were without a bishop.

This lack had long been felt. In the Southern colonies the church had been discredited by unworthy ministers over whom there was no official supervision. In New England, the Society had exercised an authority which had prevented such a situation; but, even so, every candidate for holy orders was obliged to go to England for his ordination. The journey was not only long and expensive but dangerous. Passengers across the ocean were in peril of smallpox from within and of pirates from without. Johnson wrote to the Bishop of London "that a considerable number of young gentlemen, of the best educated among us, for want of Episcopal ordination, decline the ministry, unwilling to expose themselves to the dangers of the sea and distempers; so that the fountain of all our misery is the want of a bishop, for whom there are many thousands of souls in this country who impatiently long and pray."

This appeal, with many others like it, was met in England with indifference, and in this country, especially in New England, with hostility. In England, the American plantations seemed exceedingly remote and of small importance 
and the minds both of statesmen and of churchmen were occupied with imperative problems at home. In New England the bishops were thought of not as spiritual but as political persons, agents of oppression, enemies of liberty, successors of Archbishop Laud. John Adams, considering the matter with an unprejudiced mind, said that "the objection was not only to the office of a bishop, though that was dreaded, but to the authority of Parliament, on which it must be founded. The reasoning," he said, "was this: There is no power less than Parliament which can create bishops in America. But if Parliament can erect dioceses and create bishops, they may introduce the whole hierarchy, establish titles, establish religion, forbid dissenters, make schism heresy, impose penalties extending to life and limb as well as to liberty and property." A cartoon, perhaps in caricature of the seal of the Society, represented a bishop in the prow of a ship, pelted with books and other missiles by angry colonists on the shore, and crying, "Lord, now lettest thou thy servant depart in peace." The protesting mob are calling out, "No Lords, spiritual or temporal, in New England !"

This opposition was found even among churchmen. As late as $\mathrm{r}_{785}$, the clergy and laity of South Carolina agreed to meet in convention with their brethren of the other states only on condition that they should never be compelled to have a bishop. The idea of a missionary bishop had no place in the general mind. Almost everybody pictured a bishop as a prelatical and domineering person having his residence in an Episcopal palace, from which he emerged only to go about in a coach drawn by four horses. It was felt that there were few roads in America convenient for a coach-and-four.

When, however, the successful Revolution effected the complete political independence of the colonies, the situation was greatly changed. The Congregationalists and Presby- 
terians, while they still disapproved of bishops, were not now afraid of them. Accordingly, in March, $\mathrm{I} 783$, when the independence of the United States had become an accomplished fact, though before the formal proclamation of peace, ten of the fourteen clergy of Connecticut met at the rectory of St. Paul's Church in Woodbury and elected a man to go to England to seek Episcopal consecration.

Samuel Seabury who was chosen for this difficult mission was the son of a Congregational minister who had entered the Episcopal Church. He had graduated at Yale in the class of 1748 , had studied both medicine and theology, and in I 753 had been ordained in England. During his rectorship of St. Paul's Church, Westchester, N. Y., from 1766 to 1775 , he had taken the royalist side in the political controversies of the day, and was believed to be the author of the anonymous "Westchester Farmer's Letters" in debate with Alexander Hamilton concerning the proceedings of the Continental Congress. A mob of Whigs had seized upon him; he had been for six weeks in prison in Connecticut; he had fied for safety to the King's army in New York where he was made chaplain to a regiment. In selecting so pronounced and unrepentant a Royalist the Connecticut clergy apparently had regard to the minds of the English bishops rather than to the sentiments of patriotic Americans.

The English bishops, however, found themselves unable to grant Seabury's request. He could not, under the political circumstances, take the customary oath of allegiance to the King; and they could not, without an act of Parliament, dispense him from it; and Parliament was unwilling to act, being doubtful of the effect upon the American people with whom they were concluding a treaty of peace. Then Seabury turned from the English bishops to the Scotch.

The Scotch bishops were under no obligations to Parliament. Their predecessors, in 1688 , had refused to change 
their allegiance from James to William, and thereafter had actively interested themselves in various plots to bring back the House of Stuart. They had therefore been disestablished, their churches had been destroyed, and a law was still on the statute books forbidding more than five of their adherents to meet together for the services of religion. The church in Scotland was divided between the clergy who had been ordained by English bishops, and the clergy who had been ordained by the Scotch bishops. The Scotch bishops were in proper standing ecclesiastically, but they had no standing whatever politically. The old rigor of party hatred had been much diminished by the lapse of years of peace, but the Scotch bishops had their own prayer book, somewhat different from the English, and were traditionally, though no longer actively, regarded as rebels. They were able to sympathize with a rebel from America. The fact that Seabury was in the curious position of being a rebel and a royalist at the same time commended him still further to their confidence. For they themselves were in a like position.

The appeal of Seabury to the Scotch bishops was accordingly successful. In 1784 , in Aberdeen, Kilgour and Skinner of that diocese, and Petrie of Ross and Moray, laid their hands upon his head. Skinner in his sermon gave some offence by remarking that the Scotch bishops paid more heed to the acts of the Apostles than to acts of Parliament. Seabury, who preached in the afternoon, somewhat startled the congregation by his freedom of gesture and volume of voice. On the whole, however, the service was rather more satisfactory than that which was held three years later when, in the chapel of Lambeth Palace, the archbishops of Canterbury and York, with others, consecrated William White bishop for Pennsylvania, and Samuel Provoost bishop for New York. The congregation was very small, consisting 
mainly of Canterbury's household, and the sermon, preached by a chaplain, "had very little reference to the particularity of the occasion."

Seabury, when he returned, brought with him the communion office of the church in Scotland, which he had promised to introduce so far as he was able into the church in America. In 1785 , he met the clergy of his diocese, and ordained four men to the diaconate. Thus, at last, there was a bishop in these parts.

Unhappily, the satisfaction of New England in this accomplishment was not shared by the Episcopalians of the other states. They looked askance both at the Scotch bishops as persons out of favor with the Church of England, and at Seabury, who as a royalist would probably be out of sympathy with the patriots of America. It seemed to them that the ten parsons of Connecticut who had thus proceeded to get a bishop had made a bad beginning and had acted prematurely and presumptuously. In the confused state of public opinion, while the colonies as separate and sovereign commonwealths were considering with some hesitation whether to unite in a single nation, or not, it was possible for the moment that New England might be left to have its own Episcopal Church independent of its neighbors. During Seabury's absence a general convention had been called to meet in Philadelphia in September, I785, but so strong was the feeling against the action of Connecticut and so uncertain was the bishop as to the reception which might be given him, that he stayed away, and the representatives of New England with him. The convention proposed a constitution which should unite the churchmen of all the states in one ecclesiastical communion, voted an address to the archbishop and bishops of the Church of England asking for the Episcopal succession at their hands, and at an adjourned meeting, in $\mathrm{I} 786$, received a reply which 
enclosed an act of Parliament authorizing the consecration of bishops for America. This happy state of things had been much assisted by the American minister at the court of St. James, John Adams of Massachusetts, who with his own hand had presented the address to the Archbishop of Canterbury, with satisfactory explanations and commendations.

In I789, White and Provoost having been made bishops in England, the general convention met again in Philadelphia. They formally invited Bishop Seabury, expressing by resolution their confidence in the validity of his consecration, and Seabury accepted the invitation. In the absence of Provoost, who refused to attend if Seabury was to be there, the House of Bishops consisted of Seabury and White. Peace and fraternity prevailed. The constitution which united the Episcopal churches, and which still governs their legislative action, was signed on the second of October, in the same room in the State House in which Congress had signed the Constitution of the United States.

The two documents, belonging to the same time and place, and dealing with like conditions, contain interesting resemblances. In the political paper colonies which had now become states, and in the ecclesiastical paper colonies which had now become dioceses, were brought together on the basis of a written constitution. Provision was made both in the state and in the church for representative government. Corresponding to the Federal Congress was the General Convention, each made up of two houses, bishops answering to senators and deputies to representatives. The church did not venture quite so far as the state in the direction of monarchy. It made no provision for the president or general executive officer, but only for a presiding bishop, holding office by virtue of seniority, having no very important duties, and carefully prevented from reminding anybody of Archbishop Laud. 
An important matter which had already engaged the attention of Bishop Seabury was the case of King's Chapel in Boston. The rector and many influential members of the congregation having left the town, the Congregationalists of the Old South Meeting-house moved into the Chapel while their own place of worship was being put in order after its occupation by British soldiers as a riding-school. The Old South people used the church one-half of the day, and the King's Chapel people the other half. The vacant pews were sold to new proprietors. The wardens invited the Rev. Samuel Parker of Trinity Church to come over with his congregation and occupy the chapel, but the invitation was declined. They then appointed Mr. James Freeman to officiate as lay reader. And Mr. Freeman presently applied to Bishop Seabury for ordination.

The political situation at that time was reflected in the current theology. Along with the revolt against the traditional forms of government there was a widespread discontent with the traditional orthodoxy in religion. The doctrine of the Trinity was subjected to serious criticism. A tentative revision of the Book of Common Prayer, undertaken by the General Convention of 1785 , proposed to omit not only the prayers for the royal family but both the Athanasian and the Nicene creeds; and, although the Nicene Creed was eventually retained, the fact that the proposal to remove it commended itself at the moment to representatives of the church is indicative of their state of mind. Dr. Provoost, three days before his election to be bishop of New York, wrote to Dr. White, just elected to be bishop of Pennsylvania, "The doctrine of the Trinity has been a bone of contention since the first ages of Christianity, and will be to the end of the world. It is an abstruse point, upon which great charity is due to different opinions, and the only way of securing ourselves from 
error is to adhere to Scriptural expressions, without turning into definitions."

The mind of Mr. Freeman was sympathetic with the current desire to state the doctrines of religion in their simplest terms, and to free the church from the metaphysics of theology and the entanglements of doctrinal debate. In I 783, being chosen rector of King's Chapel, he revised the Book of Common Prayer for the use of his own congregation. Every rector at that time was revising the Prayer Book, more or less, in the absence of any general authoritative action. Freeman only went somewhat further than the others. He went so far, however, as to alarm Seabury, who on his return as bishop in 1785 , declined to ordain him. When Provoost returned as bishop in April, I787, Freeman brought his case to him. But even Provoost hesitated to give him ordination, and suggested a reference of the matter to the General Convention. Freeman, however, waited no longer. In November, $\mathrm{r}_{7} 87$, he was ordained "rector, minister, priest, pastor, teaching elder and public teacher" by his senior warden, acting for the congregation.

"Then," said Dr. Jeremy Belknap of the Federal Street Church, "there was cut the aspiring comb of prelatical pride, - then was undermined the pompous fabric of hierarchical usurpation, - then was pricked the puffed bladder of uninterrupted succession; while the eye of liberty sparkled with joy, and the modest face of primitive, simple, unadulterated Christianity brightened with the conscious smile of a decent, manly, substantial triumph." The smile was too conscious to be altogether agreeable.

The neighboring Episcopal ministers protested. "Whereas," they said, "a certain congregation in Boston, calling themselves the first Episcopal Church in said town, have, in an irregular and unconstitutional manner, introduced a liturgy essentially different from any used in the Episcopal 
churches in this Commonwealth, and in the United States, not to mention the Protestant Episcopal church in general, and have also assumed to themselves a power, unprecedented in said church, of separating to the work of the ministry, Mr. James Freeman, who has for some time past been their Reader, and of themselves have authorized, or pretendedly authorized, him to administer the sacraments of Baptism and the Lord's Supper; and at the same time most inconsistently and absurdly take to themselves the name and style of an Episcopal church, we, the ministers of the Protestant Episcopal Church, whose names are under written, do hereby declare the proceedings of said congregation, usually meeting at the Stone Chapel in Boston [as the building was then called] to be irregular, unconstitutional, diametrically opposite to every principle adopted in any Episcopal Church; subversive of all order and regularity, and pregnant with consequences fatal to the interest of religion."

The first name signed to this vigorous but ineffectual protest was that of Edward Bass, rector of St. Paul's Church, Newburyport. Bass was a descendant of John Alden and Priscilla Mullens, and a graduate of Harvard College in the class of $\mathrm{r} 744$. He took his master's degree in $\mathrm{r} 747$, when in his thesis he answered in the affirmative the question, "Will the blessed in the future world, after the last Judgment, make use of articulate speech, and will that be Hebrew ?" Bass entered the Congregational ministry, but soon after followed the example of some of his brethren and sought episcopal ordination, going to London for that purpose. Becoming rector at Newburyport he had continued in his parish and maintained the services of the church throughout the Revolution. He had omitted the state prayer, and had devoted himself to spiritual rather than political duties. "Temperate and uniform in the discharge of the duties of 
his mission," said his wardens, " his conduct has been such as could give just cause of offence to no party." Even so, he did not escape being "pursued along the street by near two hundred persons who pelted him with dirt and stones and treated him with the most indelicate language."

When the war was over, Bass with his spirit of moderation and his discretion in counsel was the leading Episcopal minister in New England, outside of Connecticut, with the exception of Parker of Trinity. Parker was the natural person to be made bishop, but he declined. Bass was accordingly elected to that office, and was consecrated in Philadelphia in I797, being the first bishop consecrated in America. After a useful but uneventful episcopate of six years, he died and was succeeded by Samuel Parker, who, however, died only a few weeks after assuming office. The next bishop, after a space of six years, was Alexander Viets Griswold.

When Mr. John De Wolfe of Bristol, in I804, went to Harrinton in Connecticut, to fetch back the Rev. Mr. Griswold to be the new rector of the Bristol parish, he found the parson at the plow, "under a broad-brimmed hat, in patched short clothes, coarse stockings and heavy shoes." Griswold had been brought up on a farm, where, however, in the evenings by the light of a pine knot he had read through the entire library of the Rev. Roger Viets, his uncle. No man understood better the life and disposition of the plain people. There was nothing prelatical about him. Seabury, upon occasion, had worn a mitre, intending thereby to offend his neighbors the Congregational parsons, who had been heard to say that they were as much bishops as he was: he would show them what a real bishop looked like. But a mitre upon Griswold was as unimaginable as a royal crown upon Abraham Lincoln. Wherever he went he dispelled a cloud of Puritan prejudices. The Puritans were even free to confess that Griswold had some measure of vital piety. Shortly after 
his election to the episcopate there was a revival of religion in his Bristol parish which stirred the whole town. He was known to hold prayer meetings, a religious exercise which had no standing among proper Episcopalians.

Griswold became bishop of the Eastern Diocese, which included all of New England except Connecticut. He found twenty-two parishes in this district, served by sixteen clergymen. Trinity (Boston), Trinity (Newport), and St. John's (Providence) were strong and wealthy. Christ Church (Boston), St. Paul's (Newburyport), St. Michael's (Bristol), St. Paul's (the "Narragansett Church"), St. John's (Portsmouth), and St. James's (Great Barrington) were self-supporting, but unable to contribute much towards the salary of a bishop. Griswold retained his rectorship at Bristol. Even so, he had to live within narrow financial limits. He understood the economies of the country clergy and, on that account, was so much the more a welcome guest in their houses. He went about his great diocese, travelling in stage coaches over bad roads through rain and snow, preaching the gospel in meeting-houses and on hillsides, and encouraging his scattered congregations. He was a missionary bishop.

The episcopate of Griswold, beginning in I8I $\mathrm{I}$, and ending in I843, carried the Episcopalians of New England out of the period of depression into the period of dissension.

These stages of progress were not peculiar to this communion but belong to the general history of the Christian church in this country. At the beginning of the nineteenth century there was an ebb tide in religion. It was due in part to the reaction which followed the Great Awakening. In I770, at Newburyport, Whitefield had preached his last sermon. He stood in the doorway of the parsonage in the dark of the evening holding a lighted candle in his hand and preached till the flame sank in the socket; then he went 
upstairs, and died that night. It was a symbol of the whole situation. The flame of emotion which had been kindled in New England waned into a weary indifference. The enthusiasm and excitement of the revival meetings gave the converts a distaste for quiet services. The new way of becoming a Christian, by a psychological experience rather than by sacraments and patient nurture, had brought great numbers of people into the churches, but it had not succeeded in keeping them.

The ebb tide was also due in part to the absorbing political interests of the time. After the War of the Revolution men were engaged in the great task of establishing the institutions of the new government. This absorbing work, proceeding in the midst of discussions in which every citizen took part, so filled the general mind as to crowd out, for the moment, the old interest in religion. Congregations listened eagerly to political orations, and deserted the preachers unless they preached politics. A third influence, added to the spiritual reaction and to the political enthusiasm, was a popular unbelief imported from France. It was not altogether without reason that timid persons in New England hid their Bibles lest Thomas Jefferson should get them. Jefferson got a good many of them by a process akin to the transformation in the fairy stories when the treasure of jewels is changed into common stones. Thomas Paine was still more successful. Every New England village had its militant atheist who stopped sober citizens at the post office when they came to get their mail and robbed them of their faith. The new French fashion of infidelity, like the new French gowns and bonnets, affected the remotest hamlets of Vermont and Maine. In the colleges, the churches were extinct. At Yale, at Harvard, institutions founded for the purpose of training young men for the ministry, it was possible to find one or two professing 
Christians, but no more. At the College of William and Mary, in Virginia, the students freely debated "whether there be a God," and "whether Christianity has been beneficial or injurious to mankind." The Episcopal Church shared in this profound discouragement. In Virginia, Chief-Justice Marshall believed that it was too far gone to be ever revived. In New York, Bishop Provoost thought it would die out with the old colonial families.

This depression gradually changed into reverent faith and confidence, into new interest and progress, as it had done a thousand times before, and will do a thousand times again. In the course of nature, after the ebb tide came the flood. But the flood had its own disquieting consequences. With the new enthusiasm, and the restored interest in religion, came divisions of parties and controversial battles between them. The period of depression was followed by a period of dissension. Outside the Episcopal Church the differences appeared mainly in matters theological: the debates had to do with doctrines: the Trinitarians and the Unitarians, the Orthodox and the Liberals, the Old School and the New engaged in animated discussion. Within the Episcopal Church the differences appeared mostly in matters ecclesiastical.

The Church was growing. In 1832 , Vermont became a diocese by itself. In 1843 , Rhode Island; in I 844, New Hampshire; Maine in 1847 elected their own bishops. Then came the Oxford Movement. It was in I845 that John Henry Newman went to Rome. The debates which ensued brought out the differences between the High Church and the Low, between the Catholic Episcopalians and the Protestant Episcopalians. Eastburn had now succeeded Griswold as bishop of Massachusetts. In November, 1845, the bishop officially admonished the rector of the Church of the Advent.

That parish had been organized " with a view to secure to the inhabitants of the north-western portion of the city the 
ministrations of the Protestant Episcopal Church; and more especially to secure the same to the poor and needy in a manner free from unnecessary expense and all ungracious circumstances." The first service was held on Advent Sunday in 1844 , and the rector was the Rev. William Croswell. The congregation met in an upper room on Merrimack Street, near Causeway. When Bishop Eastburn came for the purpose of confirmation, making his first visit to the new parish, what he saw displeased him much. He wrote a letter about it to the clergy of the diocese. "I observed," he said, "to my inexpressible grief and pain, various offensive innovations upon the ancient usage of our church. In the form of the communion table; in the decorations of golden candlesticks and of a large wooden cross by which it is surmounted; and in the postures used in front of it by the assistant minister . . . I perceived with sorrow superstitious puerilities of the same description with those which already, in the case of another parish church of this diocese, had called forth a public expression of disapprobation, first from my reverend predecessor, now resting from his labors, and subsequently from myself." The reference was to the church in Nantucket, whose former rector was now the assistant at the Church of the Advent. The objectionable posture consisted in kneeling before the table instead of at one of the church chairs. The bishop proceeded further to characterize the ritual as "childish," as bearing an" offensive resemblance to the usages of that idolatrous papal communion against which our Prayer Book so strongly protests," and as likely to " expose the Church of our affections" to the "ridicule and contempt" of "all sensible and enlightened persons of other Christian bodies."

The vestry replied, very courteously, that their communion table was a very plain piece of furniture, made of pine wood, having four unmistakable legs, and looking quite 
unlike a Roman altar, and that their candles were never burned except at night, for purposes of illumination, and were used in preference to "gas fixtures or globe lamps." Indeed, the arrangements of the chancel, so far as they represented the Oxford Movement at all, appear to have introduced the new ways in the very mildest form. But the bishop would have none of them. And there the matter rested. The bishop refused to visit the parish for confirmation till the offensive ornaments were removed, and the rector and vestry refused to remove them. Each side exhibited that perseverance of the saints which in sinners is called obstinacy.

The Church of the Advent was fighting another battle in that old war for liberty of conscience and the right of difference in which the Puritans had been engaged in England. They were maintaining their freedom to order their own service, within reasonable limits, in their own way. They were asserting that High Churchmen as well as Low Churchmen had a right to live in Massachusetts. Roger Williams had made the same claim for the Baptists, and Mary Dyer for the Quakers. William Croswell was their blood relation. They were all of the same mind and spirit. And they all accomplished their great purpose. The period of discussion, both within and without the Episcopal Church, was a time of stress in New England, but the result was the establishment of the freedom to worship God, in a sense far wider than even the forefathers of Plymouth dreamed of.

When the Civil War began it looked for a moment as if the Episcopalians of New England might again be found on the unpopular side. Having stood, a little detached minority, against the Great Awakening and against the American Revolution, it was possible that they might stand aloof from the struggle to abolish slavery and preserve the Union. The factor of personal friendship entered into the situation as it 
had done in the War of Independence. The clergy of the Episcopal Church in New England knew their brother clergy of Virginia and the other Southern States in an intimacy which had no parallel in other communions. This was the result of meeting in the long sessions of the General Convention. So Bishop Hopkins of Vermont declared himself with great plainness on the Southern side. He published a pamphlet in which he maintained that the Southern States had a right to secede, and in which he argued that negro slavery was sanctioned by the Bible. Abraham kept slaves in Ur of the Chaldees, why should they not be kept by Abraham Lincoln in Springfield, Illinois ?

Happily, however, the Episcopal Church was now too strong to be dominated, or even represented, by any individual bishop. In spite of Bishop Hopkins, the General Convention adopted a loyal resolution, and prayed for the success of the Government. Bishop Hopkins, on the one side, continued stoutly in his unpopular conviction, while Bishop McIlwaine of Ohio, on the other side, went to England at the request of President Lincoln to present the Northern cause to the sympathetic understanding of the English Church. The general effect was to demonstrate again that among the Episcopalians are to be found very different varieties of citizenship as well as of churchmanship. Hopkins and McIlwaine, differing in politics, Croswell and Eastburn, differing in ritual, were all alike in good standing in the hospitable church.

Meanwhile, the church continued to grow in numbers and in influence. Trinity College, at first called Washington College, had been founded as early as 1823 . The Berkeley Divinity School was established in 1850 at Middletown, Connecticut, and the Episcopal Theological School at Cambridge, Massachusetts, in 1867 , for the preparation of men for the ministry. St. Paul's School at Concord, New 
Hampshire, Groton School and St. Mark's in Massachusetts, St. George's School in Portsmouth, Rhode Island, Pomfret School at Pomfret, sent out year by year increasing classes of privileged youth to college, and then to places of influence in the community. Out of the periods of depression and of dissension the church entered into the period of its present prosperity. Phillips Brooks is the characteristic figure of this time, whose ministry is still a living memory.

The Episcopalians, even now, are not a numerous people. There are three hundred clergymen in Massachusetts, and more than two hundred in Connecticut, eighty in Rhode Island; but only fifty-two in New Hampshire, forty-four in Vermont, and thirty-seven in Maine. The strength of the church is in the cities. The communicants in New England, all told, fall a little short of a hundred and fifty thousand. But the influence of a church in the community is often out of proportion to its numerical strength. In Connecticut in the old time, when the Congregationalists were the standing order, the Episcopalians were described as "sober dissenters." The adjective is still applicable. They are for the most part conservative persons, cherishing their traditions, adverse to change, highly appreciative of order in government and in worship. They differ from all their neighbors in being at the same time Catholic and Protestant. Some of them are more Catholic than Protestant, and some are more Protestant than Catholic, but these are the two ecclesiastical parties in the church, like the political parties in the nation; agreeing and disagreeing, on the whole, for the general good. There are now few in either party who are still of the mind of their predecessors in New England who said, "We are all good churchmen: we maintain an offensive demeanor towards them that are without." 

THE METHODISTS

WILLIAM EDWARDS HUNTINGTON 



\section{THE METHODISTS}

\section{PERSONAL AND INSTITUTIONAL FORCES}

$7 \mathrm{HE}$ historian of New England Methodism cannot well 1 avoid reference to the roots of its denominational life in old England. There is a vital nexus between the centuries as we mark them off in our chronology; and a living bond that binds the salient events in any great movement in religious or in secular history. Methodism stands for one of the distinctive movements in modern Christianity. We get at the temper, purpose, and significance of a political party, or a religious denomination, by learning something of the "movers" of the particular organism examined, which makes history and takes a distinct place in the orderly progress of civilization.

To one man in the eighteenth century all branches of Methodism, in all quarters of the world, look back, as the prime mover of the generic body to which all are affiliated, that man was John Wesley. Living in an age of religious formalism and degeneracy, he lifted up a standard of personal devotion and piety that was never doubted or impeached. Sprung from the great middle class in which, and below it, all over the British Isles, there was much of gross ignorance and superstition, he would not begin his active life before he had been trained in the best learning that Oxford could give him. Reared in the Established Church, he would not rebel against its order, though he could not be restrained in his activities by limitations which he considered unreasonable and obstructive to his mission for the spiritual 
redemption of England. Two facts in John Wesley's career are so conspicuous and of such wide influence in the progress of Methodism that they deserve mention for the purpose I have in view. One of these facts, that has an immense significance for modern Christianity, is that Mr. Wesley made preaching the Gospel the chief business of his long and marvellously active life. He was no less "burdened" with his message to fellowmen than were the Hebrew prophets who " cried aloud " and " spared not," "lifting up the voice like a trumpet." His sermons, as we now read them, were not sensational, or remarkable in literary style or captivating imagery; but were clear, straightforward discussions and appeals, and their main drift and purpose was to stir the conscience, to break through the crust of unbelief and rouse men to repent and have faith in God. The preaching of Wesley had a special emphasis given it by the very opposition he met from authorities of the Established Church. His message was not welcomed by Churchmen; so he went to the fields. Without churchly surroundings, very frequently with no accessories such as we conceive to be necessary for Christian worship and the spiritual effectiveness of religion, Wesley and Whitefield were the great preachers of the eighteenth century. The impression they made upon their age was lasting. Glad tidings, Wesley conceived, were given to the world to be published; and in ten thousand sermons, to multitudes of hungry souls, he preached up and down the highways of England the " unsearchable riches of Christ."

Another fact in Wesley's life and labors was his power to organize, by building his followers into simple but effective organic relations. This was a marked quality of his genius. He was not content with great audiences, emotional upheavals of whole communities, startling conversions, or tempestuous excitement when religious fervor was so violent as to unman men and leave them prostrate and strengthless. 
He was too profound an interpreter of true religion to be satisfied with simply exercising his power to move great audiences and stir men into religious conviction and the personal acceptance of the Christian faith and practice. He was glad to start men into a new life, help them to break away from old bondages of irreligion and sin; but he had a more permanent thing in mind as he gave his converts and followers the supporting power of organization, to bind them in sympathetic fellowship, to consolidate their influence, to make possible a wider dissemination of gospel truth than his own personal labors, marvellous as they were, could accomplish. His classes formed for the spiritual growth and encouragement of their members, his societies banded together under the somewhat stringent ethical and religious rules that Wesley formulated, his Conferences in which the preachers of this new phase of Christianity formed a brotherhood for united and effective service as ministers of practical religion, - all these forms of organic life in early Methodism in England were products of Wesley's systematizing genius. Whitefield had superior gifts as a preacher, but he did not have John Wesley's power to strengthen and make permanent the results of his preaching by the use of such social mechanism as Wesley had the skill to originate and vitalize.

When Methodism crossed the Atlantic, the two outstanding traits that were conspicuous in John Wesley's career, and which I have just mentioned, came with it in the persons and work of those who, in our colonies, began laying the foundations of the Methodist Episcopal Church (as it afterwards became) in America. I am reminded by this King's Chapel, in which we are assembled, that as early as 1736 , Charles Wesley on returning through Boston to England from Georgia, where he and his brother John had undertaken some missionary work under the auspices of the Established Church, preached both in King's Chapel and 
in Christ Church, Boston; but this event antedated even the beginnings of the distinctive movement of Wesleyan evangelism. The first of Wesley's missionaries did not come to our New World till I769. Richard Boardman, I772, and William Black, I784, were among the earliest of these pioneers to visit New England. Both these men attempted to establish a society in Boston, but failed of support. At length, Freeborn Garrettson, a flaming spirit, tireless in labors, ranging up and down the North Atlantic States with unquenchable zeal and remarkable ability both as preacher and organizer, made a visit to New England, passing from Litchfield, Connecticut, through Hartford and Worcester to Boston. On the $4^{\text {th }}$ of July, I790, he preached in Dr. Mather's church, on Hanover Street, and subsequently made some efforts to gather the nucleus of a Society of Methodists, but the fruits of his labors were not conspicuous. On this very itinerary of Garrettson's he met, on his way to Providence, another fellow-protagonist of Methodism, Jesse Lee, who, with the same evangelistic spirit as his own, was now preaching his way through New England. A Virginian by birth, with no special training for his work as a preacher, but of great force of character, Lee started upon his career in that memorable year 1776 , then but eighteen years of age; at first, simply holding cottage meetings, for he did not undertake regular ministerial work till 1783 and was not ordained till I790. His heart was drawn out especially toward New England, although his first work was done in North Carolina. The open field here, the lack of any forms of religious life such as Methodism fostered, kindled in Jesse Lee a kind of apostolic passion for attempting a new work in these young New England States. A Congregational minister and historian, Dr. Joseph B. Clark, said:

In his doctrinal teaching, Jesse Lee, the pioneer of Methodism in these parts, suited such as were of Arminian tendencies; in his fervent 
style of address he was acceptable to many warm-hearted Calvinists tired of dull preaching! The wild enthusiasm of the quakers had long since disappeared, and their numbers were diminishing. The martyr spirit which animated the first generation of Baptists had subsided with the removal of their civil disabilities, and their religious zeal suffered a proportional decline. If Jesse Lee had not come into Massachusetts, some one else pressed in spirit, like Paul at Athens, "when he saw the city wholly given to idolatry," would have found utterance, and would have had followers.

No missionary, ancient or modern, ever set out with a more earnest purpose to serve the cause of the Christian faith, than did Jesse Lee, as he rode on horseback and without escort through the rough highways of New England. At Norwalk, Connecticut, he began his ministrations and had but a small group of hearers gathered at the roadside. At New Haven the Court House was opened to him, where President Stiles of Yale College was one of his hearers. His first circuit of one hundred and thirty miles included over twenty preaching appointments; but no marked success was gained in winning converts or in organizing societies. The opposition felt, and often expressed, by the pastors of the Congregational body was a serious obstacle to Lee's work. They looked upon all Methodist preachers as heralds of strange doctrines, and as enthusiasts who were likely to kindle fires of fanaticism which would endanger the standing order of Congregationalism. Lee's services under the Great Elm on Boston Common, where multitudes listened to his sermon, were among the notable beginnings of Methodism in Boston. But more successful were his labors in Lynn, where he gathered a company of co-workers and planted the seed which sprang up and has borne fruit a hundred fold, making Lynn one of the strongest centres of Methodism in New England.

Lee's outfit as a preacher was comparatively limited. His education was elementary; but his courage, devotion, and faith, his readiness to enter untried and rugged fields, made 
him the man for the time and the work. He was built on a large plan; his voice was big and sympathetic, his heart was large, with great, unselfish motives. He had a keen sense of humor and a vital faith that makes light of difficulties and sacrifices, can carry heavy burdens brave-heartedly, and make religion attractive and beautiful by a personality that everybody loves to meet. Jesse Lee's name stands for a certain type of early Methodist preachers in America and New England that has a remarkable record in evangelism.

Francis Asbury, who became the first Bishop of the Methodist Episcopal Church, was of a different mould; a stronger mind, and of a personality more nearly after the pattern of John Wesley than any other early American leaders of Methodism. The two great elements of power found in John Wesley, which I have mentioned, were also conspicuous in Francis Asbury. He was a tireless and effective preacher and a skilful organizer. Born in England in I 745, of humble ancestry, he did not have Wesley's advantage of liberal learning; but, by great industry and studious tastes he put himself through such discipline in Greek, Hebrew, and general literature as gave him good standing as an educated man for that time. He was not built or trained for a theologian or a scholastic leader. He was rather predestined by nature and by early circumstances to be a crier in the wilderness - the American wilderness of the eighteenth century. His very limitations were in some measure his strength. For a delicately trained man to have undertaken the work that Asbury did, some one has said, would have been to attempt to fell American forests with a Sheffield razor. He began preaching at the age of eighteen, entered the regular itinerant ministry at twenty-one, and at twenty-six gave himself to the missionary work in America. Thirteen years later he was made the first Bishop of the Methodist Episcopal Church and ordained in $\mathrm{I}_{7} 84 . \mathrm{He}$ 
started from England with a purse of ten pounds, a suit of clothes and two blankets - the gifts of friends; these were his only outfit. He entered at once upon a work that was a constant succession of sacrifices and even of suffering. His horse was his usual means of journeying, and his annual tour averaged six thousand miles, through untracked forests and unbridged streams. Of slender physical resources, he braved all variations of climate and all hostilities of wild beasts and wild men with dauntless courage, and with an inflexible purpose to help found in this western world the empire of righteousness. His tours were from the Atlantic seaboard to the Mississippi Valley. He was constantly on the move. Sometimes a great revival broke out under his preaching, - as when in 1776 , in the very midst of the Revolution, he wrote from Virginia in his Journal, - "I preached from Ezekiel's vision of the dry bones; and there was a great shaking! I was obliged again and again to stop and beg the people to compose themselves, but they could not. Some on their knees and some on their faces were crying mightily to God all the time I was preaching." "This wonderful revival," he says, "spread through fourteen counties in Virginia, and burned its way into adjacent Colonies." Asbury was, as he called himself at one time, "as an iron pillar and a wall of brass." In firmness and discipline he lacked nothing of what a great leader should be. But he was likewise tender-hearted in his evangelism, always winning men into the service and faith of the Gospel. When he landed in Philadelphia to begin his work, there were only six hundred Methodists in America; at the end of his career, one hundred and ninety thousand members were reported at the General Conference of 18 I 2. His work for New England was conspicuous; for he presided at twenty-five Conferences, and gave unstintedly of his services among the young societies that needed the sanction and impulse which 
only a great leader could give. He did not have a warm welcome in Boston. His Journal has this comment:

I felt much pressed in spirit as if the door was not open. . . . I have done with Boston until we can obtain a lodging, a house to preach in, and some to join us. Some things here are to be admired. Of their hospitality I cannot boast. In Charleston, South Carolina, wicked Charleston, six years ago, a stranger, I was kindly invited to eat and drink by many - here by none.

But after a more successful visitation in Lynn he wrote:

Here we shall make a firm stand, and from this central point shall the light of Methodism and truth radiate through the State. . . . I am led to think the Eastern Church [the Congregational] will find this saying true in the Methodists, viz., "I will provoke you to jealousy by a people that were no people, and by a foolish nation will $I$ anger you."

A better feeling soon prevailed; for an original record shows that in the period I795-97, when the first Methodist church was building, subscriptions were made (of from five to ten dollars each) by Rev. John T. Kirkland, afterwards president of Harvard College, Rev. James Freeman, pastor of King's Chapel, Rev. John Murray, founder of Universalism, and Rev. Jedidiah Morse, pastor of the First Church in Charlestown.

Enough has been now said to show that the beginnings in New England of this Christian denomination that we are studying were exceedingly small. Self-sacrificing, heroic souls were engaged in strengthening and enlarging its boundaries; for nearly seventy-five years the gain in numbers and in material equipment was modest, but substantial. During this period the religious life of Methodists showed more distinctively the traits of Wesley's followers in England. The idiosyncrasies of the sect were more apparent. The camp meeting, the class meeting, hortatory preaching, demonstrative forms of worship, simplicity and even barren- 
ness in the meeting-houses, were some of the marks that earlier New England Methodism bore, and which in this region are now far less conspicuous, if not entirely obliterated. Dr. Daniel Dorchester has thus described the churches:

The first Methodist Church buildings were simple structures made of unplaned boards, entirely without paint; often, for several years unfinished. For seats they had rough planks, laid on blocks, and no backs. The pulpit was the carpenter's bench used in the erection of the building, pushed to one end of the room and a single board nailed upright upon the front and another short board flat on its top, made a resting place for Bible and hymnbook. Even such plain meetinghouses were often embarrassed with debts.

As we read of the support that most of those pioneer preachers received, we are reminded of apostolic times, when scantiest resources were given to those who were the heralds of the faith. In the year I 800 it was agreed by the General Conference that the annual allowance for each preacher should be $\$ 80, \$ 80$ for his wife, $\$$ I 6 for each child under seven, and $\$ 24$ for each child between seven and fourteen. In 1803 , twenty-six preachers received about $\$ 47$ each. So constant was the deficit that appeared each year, below the amount the New England preachers should have received, that as late as 1825 the shortage was $\$ \mathrm{I}_{4}, 5^{\mathrm{I}} 7$, and incomes were in those trying years only from 30 per cent to 70 per cent of what was expected. Today, in most of the denominations, there are stirring appeals heard for endowments that shall provide a much more reasonable average salary for pastors of small flocks. A vigorous campaign is now in progress to raise an endowment fund of $\$ 5, \infty 00,000$ to help poorly paid Methodist preachers. Those heroic men of one hundred years ago would have thought our minimum salary of today $(\$ 500$ or $\$ 600)$ a munificent living.

But strenuous conditions of life have often produced heroic men. The Spartan theory was that conditions must 
be made rigorous in order that the Greeks of that time should be disciplined to heroic standards. It is certain that easy circumstances, luxurious settings for domestic and religious life and activities, do not of themselves tend to produce the strongest types of character. Neither does poverty of itself, and of necessity, make for nobility in human character. There must be deep-set in the soul itself a principle of life, and standards of character, not dependent upon outer circumstances, whether of opulence or of destitution. Those early American preachers, like Jesse Lee, Francis Asbury, Wilbur Fisk, were representative of a real nobility in the annals of our race; untitled, with no crests or equipage, but with plain clothes, simple fare, slenderest income, they "wrought righteousness," stopped the mouths of ecclesiastical lions, quenched the violence of fiery persecution, out of weakness were made strong, and obtained a good report through faith.

There was just enough opposition to Methodism in New England to make it earnest, fearless, compact, and vigorous in meeting the situation. Sometimes harsh things were said and done. Abel Stevens, the historian of Methodism, puts in one paragraph samples of the treatment that some of these itinerants suffered: "Sabin was knocked down and struck on the head to the peril of his life with the butt of a gun; Wood was horsewhipped; Christie was summoned out of bed to answer to a charge of violating the laws by marrying a couple of his people; Willard was wounded in the eye by a blow, the effect of which was seen through his life; Kibby was stoned while preaching; and Taylor was drummed out of town." Parsons Cooke, pastor of the First Church in Lynn, wrote a whole volume, A Century of Puritanism and a Century of its Opposites, in which he poured out his vials of wrath upon the Methodists. We cannot overlook the fact that the coming of the Arminian theology into 
New England, in the preaching of these pioneers, was a distinct challenge to the disciples and preachers of Calvinism. It was John Wesley against Jonathan Edwards, as far as certain theological concepts were concerned. Edwards's theological teachings had permeated the orthodox churches; and doctrinal preaching was the predominant style of pulpit address. On the other hand, the itinerants emphasized the experimental side of the Christian faith. The appeal was made to the heart, the conscience, the springs of moral life, and not primarily to the powers of reasoning and the ability to measure the force and cogency of dialectics. Moreover, the itinerants stood upon a wider platform of appeal, as interpreters of the divine administration, in the moral government of our world. Instead of preaching a limited atonement, and a divine foreordination that doomed certain souls to eternal darkness, the new gospel, which was simply the old re-emphasized, opened the way of life to "whosoever will." The whole accent of the gospel message was different, and with what results I shall endeavor to show later. I am not aware that the fundamental doctrines of Methodism have changed since those days of debate. But some of the fundamentals of Congregationalist theology have either changed or been practically eliminated from the orthodox preaching of today.

That Methodism has made its advances, not only in New England but in its wider American fields, by employing in its ministry many untrained, or half-trained, men, is often spoken of as a reproach to the denomination. But, while this weakness in its ministry is being steadily overcome (for it has been a weakness) there has been and is a condition of illiteracy in our communities that palliates the fault, if such it can be rightly called, of letting uneducated men be religious leaders and preach the gospel with some intellectual stammering. That condition prevailed very widely in New Eng- 
land, and in all other parts, during the first two hundred years after the Pilgrims set their feet upon our shores. Lack of schools, scarcity of books, strenuous habits of daily life necessary in order to wrest a living from crude circumstances, made it impossible for the larger portion of communities to find their way to any high state of learning or intelligence in things literary or scientific. The Wesleys, in choosing men to aid them in the evangelistic work that they led, were glad to use men who were of earnest religious life and had some gift in public address, even if they were not all, like themselves, university graduates. So long as a wise leadership is in control, the Church of Christ would seem to be justified in doing what the Great Teacher himself did in selecting as his first ministers men from common life with no uncommon outfit - except that they were illuminated and moved upon by the Holy Spirit of God to declare His truth to fellowmen. Every age in Christian history has had its quota of such preachers. As the general level of intelligence in any nation or community rises, in just that proportion will it be necessary that those who teach religious truth, and stand as oracles of a divine message, be intellectually qualified for this high function by the best culture available.

I am thus led to mention one striking example of a Methodist preacher who in some respects represented the class of an uneducated ministry, but in other respects stood out alone as possessed of a genius that made him notable. This man was Edward T. Taylor, "Father Taylor," of the Boston Seaman's Bethel. Born in Virginia, in very humble conditions, he was persuaded, when seven years old, by a sea captain to take up a sailor's life, which he followed for ten years. At seventeen he wandered into a religious service held in Bromfield Street Church by Elijah Hedding (afterwards bishop), was moved by the appeals, gave his heart to God in a new act of surrender, and resolved to be a preacher 
of Glad Tidings. But he was scarcely able to read, and yet people were attracted to him " by his fervor, simplicity, and humor." It was not thought advisable, however, for so illiterate a young man to be led into the ministry; and he was soon off at sea again, this time in a United States privateer, in the war service of $\mathrm{I} 8 \mathrm{I} 2$. His ship was captured and he, with the crew, was thrown into a British prison in Halifax. Here he exercised the "gift that was in him " and his shipmates much preferred his prayers and sermons to those of the prison chaplain, who at the petition of the prisoners was relieved in favor of Taylor. Here he really began his remarkable ministry. So ignorant was he that he could not read his own text: the Bible must be read to him; but little by little he mastered the rudiments of learning, keeping steadily on after the months of his captivity, preaching in Saugus, as he had opportunity, peddling on week days and farming a little to earn a livelihood; then taking charge of a feeble flock at Marblehead; then, for nearly ten years, preaching successively in seven or eight different towns on Cape Cod, in southern Massachusetts, and in Rhode Island. In 1828 , he was called to take charge of the Seaman's Bethel, Boston, a religious home especially for sailors, a non-sectarian church. It was largely supported by Unitarians, but the pulpit, by the agreement, was to be occupied by a Methodist preacher, appointed by a bishop of the Methodist Episcopal Church. Here Taylor found the field for which he was by nature, gifts, and experience admirably adapted. Within four years he was the acknowledged popular pulpit orator of Boston. Here is a vivid description of Father Taylor by one of his closest friends - Cyrus Bartol, a Unitarian :

No American citizen, Webster, Clay, Everett, Lincoln, Choate, has a reputation more impressive and unique. He belonged to no class. In any dogma he was neither leader nor led. He stands for the sea, 
and his fame has been borne by thousands of ships, by mariners who christened him "Father," into every port of the globe.

\section{Dr. Bellows said of him:}

He had a heart as tender as his mind was strong, and his imagination was Protean; and this gave such a sympathetic quality to his voice and his whole manner that more than any speaker of power we ever knew, he was the master of pathos. Who can forget how rough sailors, beautiful cultivated Boston girls, men like Webster and Emerson, shop-boys and Cambridge students, Jenny Lind, Miss Bremer, Harriet Martineau - everybody of taste or curiosity who visited Boston - were seen weeping together with Father Taylor?

Such was one of the unlearned itinerants of the nineteenth century New England Methodism. Of course he was a rare genius. But it may fairly be presumed that there were many unlettered preachers like Taylor, well-read only in the Scriptures, but unlike Taylor, having no gift in oratory, whose hearts were burdened with messages of divine truth. They were not blest with a brilliant imagination and yet their eyes had seen a vision of spiritual things, and their tongues could not withhold the story of what they had seen and felt in their own experience.

We turn now to another personality that had great influence in shaping the course of events for New England Methodism - Wilbur Fisk. He represented another rank of preachers and leaders. His preparation was from a Christian home of modest means, and by collegiate study such as he could gain by one year at the University of Vermont and two years at Brown University, from which he was graduated in I8I5. His power resided in a wellbalanced mind, a kind heart, a fervent desire to do good, and a broad outlook upon the world with its crying need of the light and blessings of Christianity. By the natural qualifications of Mr. Fisk, it was to him that the selecting 
officers turned, when Wilbraham Academy was opened in 1826, as to a man well-fitted to be its first principal. Four years later, in I83 $\mathrm{I}$, Wesleyan University was organized at Middletown, Connecticut, and he was elected its first president. His services as one of the early Methodist educators in New England was noteworthy. When he entered the ministry in $\mathrm{I} 8 \mathrm{I} 8$, there was not a single literary institution of any note under Methodist patronage. He felt deeply the necessity of such means of training, both for the ministry and the laity, and gave himself to the cause of Christian education with great devotion and zeal. When elected bishop in I836, he declined the office, saying, "I believe I can do more for the cause of Christ where I am than I could as bishop." As a preacher he was one of the foremost of his time. A flexible, sympathetic voice, an attractive face, a native and compelling dignity of manner, and a fervor in pulpit address that stirred his audiences made him an effective minister of the faith wherever he was heard. At both Academy and College he proved himself to be the attractive and efficient leader of youth. Both these institutions received a lasting impression from his character and work. He believed that education in secular things needs to be coördinated with discipline in morals and religion, in order to be most worthy and produce the best type of human character. Whatever may be said of the weakness of the denominational school, college, or university on the side of a wide patronage, it is true that the religious note in the educational programme can be more clearly sounded in such an institution. If, however, a kind of pseudo-piety is made to take the place of high standards in scholarship, that is bad. Neither is it good if a dry intellectualism, a cynical spirit of criticism toward the whole realm of spiritual truth and the fundamentals of Christianity, crowd out of student life the wholesome power of religion that makes all learning 
clearer and more effective. Fisk taught and exemplified in his own well-balanced and elevated character that fine relationship between culture and religion which is such a desideratum in our modern educational schemes. Since his time there have been established in New England six Methodist academies besides Wilbraham, and here in our city, Boston University. Without exception these institutions - Boston and Wesleyan Universities, Wilbraham, Tilton, Kent's Hill, Montpelier, Poultney, Bucksport, and East Greenwich Academies - all have not only the religious auspices of the denomination that fosters them, but what is far more important, they have distinctive religious influences and instruction at work, as educational forces, along with the scholastic regimen. No one can measure the good done by these educational institutions. Wesleyan University has been the inspiration and the strength of hundreds of leading minds who have gone out into nearly every important department of American life, - social, civic, economic, educational, religious, - and have won distinction. Boston University has graduates in every continent, - men and women well equipped for conspicuous and responsible tasks. In the service of the Christian faith, in the wide field of education, in the realm of political service and statecraft, in the legal profession at the bar and on the bench, in medical practice and advancement, this University has sent out its well trained graduates for the past forty years and more, into all quarters of our nation and to many distant fields of service. It is impossible in my limited time to give even the list of names of those who made these educational institutions what they have become. Men of great breadth of public spirit and utmost generosity have built the material equipment; men of almost prophetic vision, and of keen appreciation of what modern education should be, have been administrators and teachers. 
A denomination must be judged by its fruits, - not simply in the count of members, lay and clerical, but in the varied leadership it furnishes for the Christian civilization in which it is one factor. A university allied to the religious programme which a Christian church naturally makes for itself, although not attempting a too strict propagandism of formal religious thinking or practice, has a function of importance to fulfill that is not narrow or unworthy. Boston University was fortunate in its founders. Isaac Rich, Jacob Sleeper, Lee and William Claflin, Edward H. Dunn, Alden Speare, Roswell R. Robinson, are the names of men who will always be remembered as the fathers of the institution. William Fairfield Warren was its educational founder, whose bow still abides in strength, - a man of the same high ideals that inspired Wilbur Fisk. President Warren had the imagination to plan large things for the University, realizing that standards must be high and great even though they can only be attained by gradual stages of growth and by approximate achievements. His broad plans for university instruction, his unswerving faith in the fortune of the institution as he looked patiently through the years of its early struggles, made him the man for the time and the task. Of noble Christian character, a thorough scholar in oriental and cosmological lore, he administered for more than thirty years the affairs of the University and all the while held aloft the torch of exemplary learning.

While we must omit many names of those who have been eminent teachers in the New England universities that have been mentioned, there was one man who taught in the higher ranges of philosophical and religious thinking in Boston University for nearly forty years, whom we cannot fail to mention, - Borden P. Bowne. He began his work here in 1876. Before coming hither he had already published a critique of Herbert Spencer's general philosophic positions. 
His contention was against the materialistic trend of the English evolutionists, led by Darwin and Spencer; and his steady purpose was to construct a philosophical system embodying such a theory of evolution as would not be obnoxious to Christian revelation and a spiritual conception of the universe and its first Great Cause. His teaching was given in a period when just such trenchant criticism of materialistic philosophy was needed as proceeded from his lecture-room. Students from all quarters, especially theological students, eagerly crowded his courses. They felt that this new voice was sounding a clear note of confidence that Christianity had nothing to fear from philosophy if the philosophy were well grounded and clearly reasoned through. Loyal to the fundamental positions of Methodism, he had no timidity in leading the thought of his denomination to new and larger outlooks for both philosophy and faith. His conceptions of theism were clearly on the side of Christianity in its great affirmations. The Ground of the universe to his thinking is not simply a driving Force working in somewhat uncertain methods through vast spaces and measureless aeons of time; but rather a personal Being, intelligent, unresting, transcendent in wisdom and power, and yet immanent in all his laws and all his works, bringing to pass the marvels of an evolving order, because evolution means the unfolding of His purposes and His thought for the universe. Bowne's period of teaching was also in a time when biblical literature was submitted to most searching analysis and criticism. So far as his teaching could properly include a philosophy of revelation, his trumpet gave no uncertain sound. The Bible is not inerrant, and yet it contains a clear revelation of the gracious purpose of God for men. In authorship, it has the mark of human limitations, and yet the greatness of its spiritual messages to the world bear the character of divinity. He did not underrate the work of 
reverent biblical scholarship; but to him the body of revelation is like the clear light of the sun, in which the spots on its surface do not dim its glory. His theological conceptions were more true to biblical standards than are those of Eucken; his theistic postulates were more intelligible than Bergson's; his view of evolution took the whole question out of Spencerian materialism and joined it to such a conception of the universe and its Creator as accords with a thoroughly Christian philosophical system of thought. His teachings, though not unchallenged in some quarters, have been widely accepted, not only among the clergy of Methodism; for, in England, and in Germany, in the educational institutions of Japan and China, his philosophical books have had the serious attention of the best thinkers as real contributions to the study of some great problems of human thought.

There is no single institution in New England that has done more for the religious interests of Methodism than the one whose history we will now trace in a few closing paragraphs. At Newbury, Vermont, in the year I840, the Theological Society of Newbury Seminary was organized. This was only an attachment to the Academy then flourishing, and consisted of a few students who were looking toward the ministry. The teachers were the Principal of the Academy and the Rev. Osman C. Baker, later, in I852, made bishop. The studies were essay writing, criticism, discussion, preaching, a curriculum quite in contrast with theological courses of today. This simple round of exercises was soon enlarged to take in the study of Hebrew, courses of lectures, and theological text-book instruction. In 1844 , the Rev. John Dempster became the head of the school, a man of unusual ability, born and reared in Scotland and a graduate of Edinburgh University. Under his administration the scope of the Institute was extended, an attractive offer of a 
location and building from Concord, N. H., was accepted, and with the name of the Methodist General Biblical Institute the school was established in 1847 , by a New Hampshire charter at Concord. For twenty years the Institute did its work there. Opening with two professors and ten students, in 1867 its faculty was more than doubled and there were thirty-three students in attendance. In twenty years two hundred and ten men had been graduated. Then this school for itinerants again itinerated, and was established in this city, under the name of the Boston Theological Seminary. It found a temporary home in Pinckney Street, and in I869 removed to the new Wesleyan Building on Bromfield Street. In that year Boston University was incorporated, William Claflin being Governor of Massachusetts. The natural growth of the Seminary soon suggested that it be united with the University as an integral part of the larger whole, and in $187 \mathrm{I}$ legislative authority was granted and the Seminary became, what it has been ever since, the School of Theology of Boston University. The College of Liberal Arts, the School of Law, and the School of Medicine were soon added as departments of the University, each to work out its own special destiny, under the auspices, support, and control of one common Board of Trustees. It was not until 1886 that the School of Theology was able to leave its hired apartments on Bromfield Street and gain a home of its own. A mansion on Mt. Vernon Street was offered for sale; the University trustees bought the property, refitted it for both dormitory and school purposes, and made it the New England headquarters for theological training of Methodist ministers. In recent time, through the bounty of generous friends, a dormitory has been added on Louisburg Square, and a new structure containing a chapel, library, lecture-rooms, and gymnasium has been built next to the main building on Chestnut Street. 
For the past three years only college graduates have been admitted as candidates for the S.T.B. degree, and even with this restriction the annual attendance has been over two hundred. They come from all quarters of the country - except the Southern States - the Middle West especially sending from some of the best of the denominational colleges and the State universities picked men of excellent equipment and promise.

This is a thoroughly New England institution. Planted in our chief city, it finds the advantages of the metropolis far greater than any superficial disadvantages. It is a great means of culture for young men to be in the very centre of its throbbing life, where the tides of business pour through the streets, where all conditions of human society are found side by side, where religious institutions of most diverse forms and tenets are established, philanthropies are in operation, education is at work in every field of intellectual advance, where music and art have their seats of influence and open their opportunities to the eager minds of youth. For a theological school to be in touch with all this vast aggregate of human interests, achievements, and vital forces is stimulating and enriching to a very high degree. It is diffcult to see how a young man can prepare for the clerical profession in such environments and turn out a dull preacher. And yet this strange result does sometimes occur!

Generous offers came from the authorities of Harvard College when the School removed here from Concord, opening its great privileges to this institution, as it has since done to the Episcopal Theological School and to the Andover Theological Seminary, if the Trustees would locate it in Cambridge. But they decided for Boston, and time has already shown the wisdom of the choice. Nearly fourteen hundred men have found their ministerial equipment here and have gone forth, some to uttermost parts of the world, 
to preach the Gospel. There has been a steady and wellordered increase of courses of study in the progress of events. Some disciplines, like Hebrew, have taken a less conspicuous place than formerly; new fields of investigation in Sociology, in Missions, in Religious Psychology and Pedagogy have been opened. This School has the honor of being the first institution in the world to set apart and maintain a distinct professorship for the comparative study of Religions, an invaluable training for those especially who expect to enter oriental missionary work.

Dr. Patton, long the president of Princeton Theological Seminary, said at the inauguration of his successor last October, "Princeton Seminary is a fortress and is committed to the defense of Christianity." President Hibben, on the same occasion, in his address, dissented from Dr. Patton's simile and said, "Modern warfare has proved the futility of the fortress, and the fortress at the present time in the affairs of the Christian world has but one function, namely, to throw wide its gates in order that those within may advance for a sortie which marks the beginning of an aggressive campaign. We believe that in the day before us there will extend the long line of an aggressive campaign across the battle-fields of Europe, and into Asia, and which will finally girdle the whole earth. Let us therefore of every nation and of every tribe, of every creed and ritual, whatever our name or sign, come together in harmonious and united ranks, moving forward toward that ultimate victory which will inaugurate a new era of universal peace and good will among men."

The Seminary of theological learning that we have been considering is acting under this latter conception. This is the ideal for Methodism. It is what New England needs, and what the world needs - an institution that is the training ground for active and aggressive campaigning against 
the prince of the power of the air, against spiritual wickedness, in high places and low places, wherever the foes to human life and human society lurk - "organized evil, injustice, inhumanity, the scorn of God, and hostility to the law and love of Christ."

A Christian denomination in our time has a new set of demands upon it that must be met if its life is to be efficient. Creed-making is not now in order. Looking backward is not the right direction for the vision that is to discover the will of God for our age. The cloister is behind us. Intolerance is slowly vanishing. Superstition in religion is fading away. What Methodism has been doing in practical ways, and by its genius should do more effectively in the coming age, will be considered in my second lecture.

\section{PRACTICAL BEARINGS OF NEW ENGLAND METHODISM}

The Pilgrims brought with them two things which had much to do in shaping the New England type of American life, a Calvinistic theology and an independent, or Congregational, form of church polity. It was natural for the descendants of those sturdy pioneers, and for their successors - immigrants from Great Britain especially - to feel that the Congregational association of independent churches on these shores held a substantial primacy as a witnessing body for the Christian faith. As this feeling of primacy came to be widely held, and even proclaimed, the feeling grew into a belief and the belief exhaled itself into a kind of atmosphere, in which Congregationalism " lived and moved and had its being" with a fair degree of complacency. Nothing disturbed the serenity of this atmosphere until Christian confessions, other than that formulated at Geneva by John Calvin, edged their way into these colonies along the North Atlantic coast. Baptists under the lead of an English 
preacher appeared as early as I635. Roger Williams obtained a charter and founded the colony of Rhode Island in 1644 , with the provision that freedom of conscience should be a fundamental right. But that same year Massachusetts issued laws against Baptists, imprisoned several in $165 \mathrm{I}$, banished others in 1669 , and in 1680 the doors of a Baptist meeting-house in Massachusetts were nailed up! Representatives of the Established Church of England fared scarcely better in the Old Bay Colony; for in I629, Governor Endicott shipped off two members of the Church of England without ceremony - even though they were of the original patentees of the Massachusetts Bay Colony. Quakers in those times (in the seventeenth century), who were at all defiant of magistrates, were punished cruelly and some were even put to death. Methodists were also subject to like opposition. Endicott's doctrine was, "God forbid that our love of truth should be so cold that we should tolerate error." But it is not my purpose to dwell on the hostilities that Methodists were called to face, and to outlive, within the borders of New England. Only so far as it was necessary in order to obtain an equal chance of enjoying religious liberty did the preachers of Methodism engage in polemics. They felt that the genius of their faith was constructive. It was their business to build, not to fight; to preach against sin, not against dogmas; to make the gospel attractive and not repulsive, and win men into the faith and following of Christ.

The most serious reaction against the Calvinistic theology of New England was the emergence of Unitarianism. This movement, or protest, was led by men of high character and intelligence, and within New England especially had great influence among the refined and intelligent elements of society. Unitarians of the School of William Ellery Channing, Henry Ware, George Putnam, Rufus Ellis, James Freeman Clarke, Andrew P. Peabody, and Edward Everett Hale, 
represented the wealth, cultivation, and public spirited citizenship of Boston during several decades of the nineteenth century. So far as prestige was concerned, in the intelligence of its membership, in the ability of its preachers, in the philanthropic activity of its churches, in devoted and efficient service to the State, by noble citizenship, the Unitarian Church was a strong rival of Congregationalism for superiority in Boston and Massachusetts. Methodism was by its genius and purpose destined to take its course of procedure not in the wake of Congregationalism, nor could it enter into alliance with the Unitarian movement. It was less rationalizing than Unitarianism in its interpretation of the Scriptures, and in its analysis of the divine nature and government; but more liberal than Calvinism in its philosophy of salvation. So Methodism was a distinct factor in the theological aggregate represented by the various churches. We must assume that Methodism was conscious of a definite kind of religious service to be done by its membership for the world. This distinctive work was partly determined by its machinery. An itinerant ministry, short pastorates, a connectional bond between societies that consolidates effort and influence, official oversight by men set apart to superintend (for the bishops were, and are, simply officers set apart, not ordained, to a special office of supervision), all such organic features of the denomination made it natural for the church to keep steadily interested in its own form of religious service, and work out its own destiny. But this organic body has always recognized the need of keeping in friendly relations with other Christian churches. Loyal to its own fundamental principles, holding the faith as a good steward, it has also been ready to show the friendly and hospitable spirit toward others of different name and type at every point of contact which community service presents. 
I. The theological tenets of Methodism - such as the doctrine of the trinity, the atonement, the free will of man, the expulsive power of divine love in the human heart, the necessity of the new birth, and the doctrine of the resurrection - still stand as the buttresses of the denominational beliefs; but, it must be said at the same time, the emphasis is placed not so much upon the acceptance of any dogma, when a new member seeks admission to the Methodist fold, as it is upon the experience by which the child, or the man, may be able to say, "I know that I have passed from death unto life"; "whereas I was blind, now I see"; "old things have passed away, all things have become new." The principal confession is that the current of a new life begins to move in the deeps of the soul; the vision is cleared of film and cloud, and is opened to a new realm of spiritual things; the old material region of actual experiences is illuminated by a new light that transforms and glorifies it, making it a new world. I cannot discover, however, that there is among the people of Methodism any rigid uniformity of opinion where men are called upon to define in exact language what they severally hold in explicit terms as their doctrinal belief in the trinity, or the atonement, or eschatology. The difficulty that always lies in these doctrines of the faith, eluding by their transcendent scope all scientific accuracy of definition, makes them rather the background of Christian thinking and religious service than the very tools of practical work. I do not thus underrate or slur the great elemental doctrines of Christianity; for it is the glory of our faith, and not a reproach, that it contains these vast themes to challenge human thought. No theologian can do them full justice, no philosopher sees clear through the veil that shuts off the supernatural realities from our full understanding. Here is a body of Christians, lay and clerical, organized, differentiated by a common purpose and common 
hopes, for what? The whole history of this body for which we are speaking is an answer. Methodism has gone out into its work under the commission of its Lord - " go ye into all the world and preach the Gospel to every creature." It is instinct with life. It stops at no artificial frontiers. It passes by no class, or race, or human conditions. It is in the world to help to save it from all that degrades and imperils the human soul. It will not allow wealth to paralyze its energy; nor poverty to chill its ardor. It has no separate ministries for the rich or the poor, the black or the white man, the learned or the unlettered. "The world," with its boundless needs in spiritual things, "is its field."

2. It is interesting to mention the fact, showing that New England is the starting ground of large movements, that it was from Boston that Dr. and Mrs. William Butler went in 1856 , under commission from the central authority of the Missionary Board, to undertake Christian work in India. They had scarcely gained a foothold there when the Sepoy Rebellion burst over the very scene of their labors, and the family fled to the mountains for their lives. The storm of rebellion, after much bloodshed and social upheaval, was at last stilled, and those dauntless missionaries, the Butlers and their associates, laid the foundations of what became a great Christian work for Hindu paganism; so that when Mrs. Butler, as a widow, revisited the scene of their labors in 1906, she found in that Jubilee year that the seed they had planted in the days of darkness and danger had in fifty years brought forth fruit a hundredfold, and thousands were numbered in that once heathen community as faithful followers of Christ. That same man of apostolic zeal, Dr. Butler, having retired, after his years of service, from the India mission, sought another field of evangelizing work and was commissioned to a difficult task in Mexico in I873. With remarkable success he and his family, with 
other associated workers, centralized their labors in Mexico City, gathered societies in many other towns, built churches, and put the leaven of a wholesome type of Christianity into that great country which so sorely needs the cleansing and the enlightenment of a "pure and undefiled religion" to save its people from anarchy and destruction. Dr. John W. Butler, worthy son and successor of his father, has held steadfastly to his post, as the head of the Mexican mission work, after his father's death, - even through some of the most threatening periods of revolution since President Diaz withdrew from the government.

An important missionary organization originated in Boston, when eight women of large and prophetic vision formed the nucleus of the Woman's Foreign Missionary Society of the Methodist Episcopal Church in the year r869. From that initial meeting of those leading minds there has grown a great organization whose well-conducted machinery engages the devoted interest of thousands of women, whose systematic efforts in raising funds for the support of workers in oriental fields result in very large annual contributions. Last year this Society raised for foreign missions \$931,780. This great religious force is also of New England origin. One of the first missionaries to go to a foreign field from New England was the Rev. Melville B. Cox, who in I833 established a mission on the west coast of Africa; but lived only a few months. The Rev. James Mudge entered upon editorial work in India in I873, where he did most efficient service, through a gifted pen, for the missionary field in South Asia. Since his return from the Orient, he has done unstinted service to the cause of missions, as well as to the general religious welfare of his church, by his abundant writings, which have appeared in books and periodicals. His History of the New England Conference is full of stirring accounts of the religious progress of the denomination. 
3. An association of Methodist laymen began in 1854 the enterprise of publishing a religious paper. The Unitarians have had the Christian Register; the Congregationalists their organ under their own name, which has just celebrated its centennial; the Baptists, The Watchman; the Universalists their paper of the same name. Zion's Herald was in the field as early as I823, a denominational mouthpiece for New England Methodism especially. It has always been independent of any ecclesiastical control, and has claimed and used the right to discuss freely the broad interests of the church, and all questions that touch the moral and religious welfare of the community. Some of the most gifted men in the church have been in the line of editors, such as Abel Stevens, Gilbert Haven, Charles Parkhurst. This layman's enterprise has been so well conducted that the paper has won a distinguished place as a religious journal, and its material success is witnessed by the noble building on Copley Square that is not only the home of Zion's Herald but the headquarters of the varied clerical and lay interests of the denomination in New England.

4. It has been a fundamental principle in Methodism to seek the coöperation of Christian women in the life and service of the church. Women have not yet been granted ordination to the ministerial functions, but they are now eligible to membership in the General Conference, the lawmaking body of the denomination, and in the officiary of individual societies they are likewise possible members. New England Methodism has not been backward in falling in with a general movement, not confined to this church, but wide-spread in Europe and in the United States, which enlists women in a well-systematized service of charity and social uplift. Here, as elsewhere in Methodism, the Deaconess Association is the name for this class of Christian work. In 1890 this arm of church service was established 
in Boston; it has since been widely extended throughout New England and the larger cities of the United States. The principal features of this organization are, first a Training School, where young women are instructed for a certain time in the duties of the deaconess and in such courses of study as are necessary in order to give the candidate a fair equipment for becoming an instructor to the unfortunate and the ignorant whom she is to meet in the homes of poverty and destitution. Almost immediately after the Association was established, a hospital was found to be a necessity. Offers of money came, interest was roused, and in I896, a large and well-furnished hospital was built, which has been doing its beneficent work with the coöperation of many of the chief physicians of Boston. Another Deaconess Hospital was established in Concord, Mass., - the gift of Charles Emerson, a nephew of Ralph Waldo Emerson, and was equipped by citizens of Concord. The benevolent spirit toward this Association was contagious, and by a gift made in I9I3, a home for Aged Methodist Women was also established in Concord, and in that peaceful valley has become the beautiful home for many who otherwise might spend their declining years in discomfort, or even in want. The function of the deaconess in church life is really that of an assistant to the pastorate. She ministers, but does not preach. In a hundred delicate ways she carries to homes that are not what they ought to be sympathetic teaching, not only in matters purely religious, although the comfort and the warning of the Gospel of Christ are always felt in the messages she bears; but, in lessons of order, cleanliness, good taste, the care of children, - the whole round of family conditions and relations - the deaconess is the messenger of light and blessing. There is a doubt in many minds whether this self-sacrificing work should be done so nearly without compensation, as it is done. The work is too trying, 
the office is too valuable as an ally, to ask noble young women to give themselves to it for an income that is a mere nothing when compared with that of the average teacher in our public schools.

5. One of the chief problems for modern Christianity to solve for the great municipalities where there is a dense population, the commingling of many races, and all sorts and conditions of human life, is how to leaven these masses with moral and religious power. The regularly organized churches of all names have felt the insistence of this broad problem. It is proper to mention here one among several institutions in Boston that is doing great service for the social uplift of the depressed people of our city, whose scope and power is so great as to command wide attention, the Morgan Memorial. Its origin and early history are interesting. Henry Morgan was its founder, a man of somewhat eccentric methods, independent, philanthropic, warmly evangelistic, a lover and helper of the poor and despised. He felt a call to go after outcasts. He was a revivalist and opened a mission in 1859 in the old Music Hall. Then the Boston Union Mission Society was organized and, with Mr. Morgan as its chief executive, there developed the very elements which now characterize the greatly enlarged institution. In I868, James Freeman Clarke's church on Indiana Place was sold at auction and purchased for the growing work by Mr. Morgan. This became the centre of his remaining efforts, and when he died he left the Chapel property by will to the Benevolent Fraternity of Churches in Boston, - on condition that the religious work of the institution should be in control of the Methodist Episcopal Church, while the Unitarian body should furnish material support and oversight. But finally, in 19r2, the controlling Board for the entire work, instead of being limited to the representatives of two, was made to include members from several denomi- 
nations. This work is one of the most successful examples of the institutional church. It is planted in one of the most cosmopolitan districts in the world. Within half a square mile are quartered fifty thousand persons. Twenty nationalities are brought together, or have drifted together, here; ninety-seven per cent are of foreign birth or extraction; and about five per cent are Protestant. Saloons and vicious resorts are abundant. This section was once respectable; in recent years of bad repute but for this institution. What is its work? In the first place, it reaches after the children, giving instruction in their most teachable years to the young people who have little or no home instruction, and are not ready for public schools. There is carpentry work for boys, lessons in housekeeping for girls. There is opportunity for training in music and other refinements. There is a studyroom, where children who are in the public schools may have a quiet resort to prepare their lessons, and where there are teachers to help them in their problems. A gymnasium, a club-room, a game-room, are also provided, so that recreation may be a part of the daily life of these children who resort to this Common School for Life. But, above all, the religious training of childhood is not overlooked or slighted. Children form the choir on Sundays; they are ushers and take up the offerings. They listen to a real sermon, not small talk, or mere stories, but earnest appeals meant to engage their best thought on the highest themes. There is a real children's church. Then, as we turn to the work for the adult life of the South End, under Morgan Memorial auspices, there is found the same wise planning for a thoroughgoing regimen. The insistent fact is always kept in mind that human wrecks are at the very doors of this church, and the doors are open. Rescue work is the dominating interest in the hearts of those who are doing the service here. The religious note is the deepest in the message that Morgan 
Memorial is sounding forth to that community of fifty thousand. The derelict is warned of his danger, shown the possibilities of finding a regenerate life; hope is kindled in almost hopeless souls, an atmosphere of sympathy, faith, and prayer envelopes the poor slave of appetite and passion, and he makes a start toward a better manhood and a redeemed life. On such foundations it is possible to build men up in character and usefulness. Safeguards are supplied; a reading-room, club-rooms, baths are open for wholesome influences to take the place of the old noxious ones. Then comes the whole ingenious plan by which industrial opportunity is opened to those who have no place elsewhere to earn their way. They are given a chance. They are helped over a period of discouragement and destitution.

Morgan Memorial is a great workshop, as well as a church. Motor trucks are driven through the resident districts of Greater Boston once a month to gather cast-off articles from a thousand homes - clothing, shoes, furniture, paper, crockery - all sorts of material; and this vast conglomerate is here disinfected, sorted, repaired, renewed, remodelled, by skilled workers in this great workshop, and thus becomes merchandise which at low prices is available to the people of the district who have little money to spend, but are sure that what they buy is worth every cent that is paid. The industrial aspects of this institution are simply the reflection of that profounder work that is going on all the time, as human life, taken at its lowest levels of moral character and efficiency, is graciously led step by step up out of the "miry clay" up to the clean and bracing heights of Christian manhood. The success of this remarkable work of Morgan Memorial in its recent development is due to the genius and consecration of Dr. Edgar J. Helms, whose faith, ingenuity, heroic perseverance, and devotion have made his efforts fruitful of such great results as appear 
in the establishment and progress of this great institution. There will soon be dedicated a new building for worship to be known by the inclusive name of "The Church of All Nations."

There is no reason why such a general plan of rescue and reformatory work could not be duplicated in many cities. It would be hard to find a section of any great city where the conditions for christianizing the social disorder are harder than here in our own South End. Dr. Helms has attacked the problem with an undaunted faith that the Christian religion can deal with all the elements of the situation. The degrading passions, the grovelling appetites, the loathsome vices, the squalid homes, the discouraged, broken-down characters that otherwise would riot in their uncleanness and woe, are now met by this organic power, wholesome, cheering, cleansing, and in the moral desert an oasis appears. I can only mention the Medical Mission maintained since I893 at Hull Street, and the Immigrants' Home, established in I888, in East Boston; both, agencies of untold good.

Methodism is using active forces for reaching the larger aggregates of the foreign population in Boston and other cities in New England. At the North End in Boston, a Mission Church for Italians has been sustained for many years. Devoted laymen, as well as clergymen, have given both material and religious help to this work. It has been found that a native Italian could best lead the enterprise and meet the problems which naturally rise and tax ingenuity and faith. A young man is now in charge of the mission, the Rev. C. M. Panunzio, who, as an immigrant boy, struggled his way through academy and college, mastered the English language, and has become a preacher of rare ability and persuasive power. In Worcester, there is a large community of Swedes who have become a self-supporting body of 
Methodists, having their own Conference organization of Swedish preachers. In Lowell a steady work is going on among the Greek population, which has become numerous in recent years. Thus, at many points the aggressive endeavors of the denomination are bringing promising results for the cause of christianizing the masses of immigrants who are crowding within our borders. Single-handed no denomination can hope to do more than a small share of this work. Here is a field for that coöperation of Christian forces that seems possible for the Federation of Churches to accomplish. The Federation in Massachusetts is now chartered, has at least thirteen denominations and two thousand churches in its ranks, and is using its combined influence in support of desirable legislation against manifest social dangers. It is interested in social service problems, in philanthropies, and in the question of putting new life into the rural church and community, which is often so barren in religious things as to be almost pagan. Its Commission for Social Service was appealed to by the last Methodist Conference in Boston "to make active efforts for the redemption of the individual and society; to urge all pastors to coöperate with every agency in their communities looking toward social improvement; to insist that highest property rights and human rights are one, and to get each community to attack in its own way whatever problem is most in need of solution."

In looking back through the annals of New England Methodism, one is struck with the decided change that has gradually taken place in the institution of the Camp Meeting; for it was, during the first half of the nineteenth century, a distinct factor in the religious life of Methodism. At Eastham, at Martha's Vineyard, at Sterling, and many other points in the New England States, the annual gathering in tents was the chief religious event of the year. Emi- 
nent preachers were heard, vigorous appeals were made to the indifferent and the ungodly, crowds flocked to the meetings, and many were led from darkness to light by these services in tented groves. But in recent years there has been a decided falling off in attendance upon these gatherings, and the emphasis of religious effort has been in part withdrawn from such occasional and sporadic means of grace, and given rather to the orderly programme of religious nurture in the churches, and the steady unremitting work that goes on without spectacular accompaniments.

Methodism has not been backward in showing its interest in the great moral movements which belong to New England history. In the anti-slavery agitation which culminated in the Civil War the annals of this denomination show that the debates in conferences and conventions were of most vital character. After William Lloyd Garrison began publishing the Liberator in 1832 , popular indifference to the institution of slavery was disturbed, and discussion began. There were radicals and conservatives on this question, as upon most great issues, and the leading preachers of New England Methodist churches were not all on one side. It was felt by the radicals that Wesley's denunciation of slavery was right when he called the slave trade "the sum of all villanies"; at any cost, they said, the institution of slavery ought to be abolished. A more moderate party, of which Wilbur Fisk was a leader, said that there were consistent Christians who owned slaves, and the whole question should be so treated that Southern Methodist slaveholders would not take offence. The Church, North and South, should be saved from a schism, and some means adopted, if possible, that would secure the final abolition of slavery and also preserve the unity of the Methodist Episcopal Church. Fisk and his party proposed the colonization of the colored people; but this scheme did not appeal to the radical 
brethren. In 1842 a few leading radicals withdrew from the Methodist Episcopal Church and formed a new organization, named the "Wesleyan Methodist Church." This secession did not attract a large following, and only increased the zeal of the anti-slavery men, who determined to debate their cause through to victory within the ranks of the Methodist Episcopal Church. Finally, in 1844 , the General Conference settled the issue between the pro-slavery and the antislavery wings of the church. The South demanded that the fact of slaveholding should be no bar to any official place in the church; the North refused this demand. On this rock the split occurred; the Methodist Church, South, was formed as a separate body, and the New England radical leaders were satisfied that their cause had triumphed by this separation, which relieved the Northern Methodists of any fellowship with slavery. All through the ecclesiastical struggle, and beyond that period to the close of the Civil War, the part that New England Methodism took in the agitation which made anti-slavery influence powerful and finally triumphant was not uncertain or insignificant.

Methodism has also a clear record in another great moral interest that is not provincial, or sectional, but touches a world problem; and that is the cause of temperance. In this, as in the anti-slavery cause, the people of Methodism are not united as to the best means of promoting the campaign against the evils of strong drink, - its manufacture and its use. Some choose to be advocates of Federal prohibition, others of State constitutional prohibition, others of prohibition by State legislation; some give their efforts to the Total Abstinence Society, others to the Anti-Saloon League. There are advocates of local option as the best means of fighting a persistent and sometimes malignant foe. But the principle upon which all unite is that the forces of intemperance must be boldly and unflinchingly met, and 
finally vanquished. New England is sorely vexed by the demon of intemperance. The cities are too often dominated by the rum power, and rural communities are not free from the blight of this curse. In the Methodist Annual Conferences, therefore, the theme of the temperance cause is always at the front, and renewed devotion is pledged by the ministry for unanimous and increasing efforts to extirpate this evil from society.

How does the Methodist Church polity answer to the religious needs of our New England conditions? This church has lived long enough in this section to demonstrate its modes of procedure, to give evidence of its temper and purposes, and to point to its actual successes in winning its way among the sisterhood of churches. In the year I 800 its New England membership numbered nearly 5,000. In the next thirty years the total reached was over 44,000 ; and in 1860 it was nearly 104,000. The average yearly increase for the nineteenth century was 1570 . At present, the aggregate membership for the New England States is about 168,000. Statistics show that the increase was much more rapid in the first half of the nineteenth century than it has been since I860. The great increase by immigration of a Roman Catholic population in the latter period, and a constant decrease of native New England families, may help to account for this fact. Of all the bishops elected to be the chief officers of the denomination from the beginning, twelve per cent have been New England born. These things indicate that the people have been awake to their opportunities, have sown beside all waters, and gathered the fruit of their labors in many fields; and may be taken as witnesses to the effectiveness of the special agencies that Methodism has used.

It has been thought by some interested observers that the short pastoral terms, limited first to one year, then 
lengthened from time to time to two, three, and five years, weakened the effectiveness of the Methodist ministry. The time limit having finally been removed by the General Conference, the Methodist pastor may now hold his place as long as seems best to him and his flock, and the appointing power. But, either from the general conditions prevailing among all denominations, which conditions do not favor long pastorates, or because the Methodist ministry long ago formed the habit of frequent changes, and the habit is not broken, there are very few pastoral terms that extend beyond five years. However, when the average length of pastorates in the Congregational and Baptist churches in New England is less than five years, there seems still to be some justification for the proposition mentioned in some quarters that a time limit might be restored. I have already alluded to the fact that the early ecclesiastical conditions here, formed under the principle of independency in each parish, had a marked influence upon the entire religious life of New England. It has been asked, how does the lack of complete independence in the churches of the Methodist communion get on in this atmosphere, among these traditions, working alongside of supposedly freer organizations? We answer, the churches have about all the liberty that they can wisely use, and bishops do not often venture to exercise arbitrary power over the ministers, or societies, feeling perhaps the influence of the general spirit of independence, natural to our democracy.

Two or three facts may now be appropriately mentioned which are larger than any provincial interests: for the connectional forces which play through the entire denomination make it impossible to consider any one section, like New England, as very different from any other. And yet there is a distinction that sometimes differentiates one region of denominational life from another. 
I. There is less conservatism in New England than in the West, anomalous as this fact may appear, since the general spirit of the West is venturesome, bold, and eager for new things. A common opinion among New England Methodists, for example, is that our Articles of Religion are many of them antiquated and quite meaningless to this generation, having been taken largely from the Thirty-nine Articles of the Established Church of England, which were formulated in a time when there was a bitter conflict between Romanism and Protestantism. The issues of Christianity are now vastly different. New England has raised a serious doubt whether it is wise for a great denomination to carry from age to age, in its Book of Discipline, a set of creedal statements which do not reflect in the best way the fundamental beliefs of the church in this time. Why should the age of Henry VIII, or Edward VI, give to twentieth century Methodism its principal articles of religious belief ? Some New England representative minds are not content with the conservatism that holds fast to a "creed outworn," or outlived, in the progress of thought and by the changed conditions of Christianity. When it is said it is well to retain some of the symbols of an ancient faith which were beaten into shape under fierce and determined polemics, it may also be proclaimed that while the past may have some claim upon our historic sense, and even our veneration, the insistent life of our own time demands that the statement of fundamental beliefs be such as a child may comprehend, and worthy of the assent of any modern Christian.

2. It is often the case that the exaggeration, or overworking, of a principle in an organization of any kind has unfortunate results and does not make for success. Expansion has been a principle in the life of Methodism ever since Wesley said, "the world is my parish." He was tireless in his purpose to gather followers in every quarter of Great 
Britain. His representatives in America were of the same spirit. The new conditions in this new world seemed to lend themselves to fostering this aggressive, exploring, missionary spirit. But in New England there is a reaction noticeable which results from attempts to expand too widely. There have been too many feeble societies started where there was no hope for, and no need of, a new enterprise. The idea of federation as a counter to this error is beginning to make itself felt in localities where expansion would naturally lead toward extinction. In the settled conditions of New England the old methods of the itinerant clergy, who like flying scouts followed up every highway and every trail where scattered families dwelt, cannot find place.

There is one prominent religious interest that is felt very widely in the ranks of modern Protestantism, and is receiving considerable attention in the churches of New England; that is, the great desire on the part of many leaders of thought in the different church bodies for a closer bond of fellowship. "Church Unity," if it means one organic body that would include all of the disunited members of the Protestant family of churches, seems to most men whose opinions are well based, impracticable and utopian. Some advances may be made toward a more compact and efficient order in Protestantism. For example, it is an anomalous and a reproachful condition for Methodism to show, in its national statistics, that there are sixteen varieties of Methodists in the United States. There are also fifteen varieties of Baptists, twelve varieties of Presbyterians, twenty-one varieties of Lutherans! It seems to some watchmen on the towers of New England that effective steps might be taken in the direction of unity by the denominations so prolific in "varieties," if the minor differences that now mark these fragments could be sunk out of sight and the fragments be brought together. Negotiations are now going on between the Methodist Episcopal 
Church and the Methodist Episcopal Church, South, which it is fervently hoped will result in the reunion at least of these two bodies separated because of slavery in I844. If the denominations first mentioned could lead the way in such a consolidation, they would serve a great purpose and would heal some of the divisions in Protestantism which seem unnecessary and obstructive to the progress of our common faith. Such movements would be first stages in what might later become a still more comprehensive uniting of Christian forces; but there are no very significant signs in our sky that there will be any speedy working of a centripetal power that will move all Protestantism toward "one fold." There is a singular persistency in religious types; perhaps this loyalty is a characteristic of New England churches especially. Whatever it is that shapes the type - whether dogma, or ritual, or authority, or freedom; once the particular form in ecclesiastical things is established, or set, the tendency is for that type to persist.

After all superficial matters in Christianity are harmoniously settled, the fact remains, and will always remain, that the deepest, finest, and most effective elements of our faith cannot be confined to any sectarian boundaries, and do not depend upon the wiping out of all confessional distinctions. There might be as much danger of secularizing Christianity if there were one vast Protestantism organized in one body, as there is in one hundred and fifty separate religious bodies that now exist in the United States. The spiritual life that should be common to Christians of every name is the one supreme interest that is immeasurably superior to visible or organic unity. In some sections of New England last year there was a decrease in the membership of Methodist churches, in others an increase is reported. Numbers, whether increasing or decreasing, do not tell the whole story. Is life increasing - the life of genuine piety, self-forgetful, 
generous, dynamic? Is this kind increasing in any fold, under any name whatsoever? Then, if it is, we rejoice: for the Head of the Church Himself must rejoice. If we have interpreted Methodism correctly, this is its temper toward all other faiths in New England and in Christendom; and it is also learning to deal kindly, patiently, helpfully with the poor, misshapen religions of paganism.

In the year I866, the centenary year for American Methodism, a great Convention met in Boston composed of twelve hundred delegates from all the New England States, to celebrate the work of the denomination for its first hundred years in this nation. Many of the chief interests of the church were discussed by leading men. A stirring service was held under the great Elm in Boston Common where Jesse Lee had preached in I790. The Convention closed its three days' session by a thronged Festival in Music Hall. Bishop Simpson, the preëminent orator of all Methodism in that time, made the final address. Some of his searching appeals are worth our attention today. He said: "Why this Convention? We have taken each other by the hand. You go back to Maine, to Rhode Island, to Vermont, to New Hampshire, to Connecticut, feeling that you are members of one great brotherhood, cemented together by the strongest ties, and going forth to work in harmony with the great Christian denominations of the land, in bringing this world nearer to Christ. This is the great work. Let us preach the glorious doctrines of the Gospel as set forth by our fathers. We have nothing to take back, nothing to abate. Wherever we go, let us proclaim the glad tidings of great joy. . . . I think Methodism has done much, and I rejoice; but there is a great deal that is not accomplished. I would infuse the spirit into the church, if I could, of counting nothing accomplished while anything remains to be done. Though rejoicing in the past, let us gird ourselves 
294 RELIGIOUS HISTORY OF NEW ENGLAND

afresh and consecrate ourselves to the work before us. While we are reconstructing the nation, let us reconstruct society and bring the world to the foot of the Cross of Christ. This is our great mission, - God help us to perform it."

And all the people said, Amen. 


\section{VII}

THE UNIVERSALISTS

JOHN COLEMAN ADAMS 



\section{THE UNIVERSALISTS}

T the early days of the old Bay Colony, there ran 1 through the dense forest of the Berkshire Hills a slender trail from the bottom-lands of the Connecticut to the valley of the Hudson. It was the great Indian thoroughfare by which the silent bands of the aborigines on their war-raids crossed the ranges that divided their territories. That was the route followed by the first road-builders of the settlements; its grades and directions guided the engineers who staked out the railway which still bears its laden trains from east to west; and recently a smooth and durable roadway has been constructed for automobiles along those same contours, by which hundreds of swift cars now daily pass from valley to valley. Crowds now travel where the dusky scout once trod a weary path of privation and peril. So the theological thought of New England today easily moves along the lines once traced in spiritual travail by a brave and hardy group of souls, in much jeopardy of good name and standing. The earliest of them are as shadowy and uncertain a band as the makers of the Mohawk Trail. Who can tell the names of the first keen-sighted souls alert to see the foregleams of the Larger Faith in the final harmony of all souls with God?

Some think they discern the figure in that paragon of statesmanship and intellectual chivalry, Sir Harry Vane, the younger, whose broad and radical views seem to have included a belief in the salvation of all flesh. He certainly declares his belief that the Christ " is become the ransom for all sinners; and not for those only who so believe as that they shall be saved, but for the whole world." $\mathrm{He}$ 
were a worthy forerunner in the way, and we may fairly place him in the van. The early annals of the stirring town of Marblehead record the daring affirmation of one Joseph Gatchell, being, as his contemporaries wrote into the county court records, "instigated of the divill" to say that "he would be a very imperfect Saviour" who delivers only a part of his people from hell. Samuel Gorton of Rhode Island, in 1637 , dropped a phrase which has remained in the minds of the religious ever since, when he declared that "there is no heaven but in the hearts of men; no hell but in the mind." But the early voices that heralded the dawn of a new religious faith and spirit were faint and few in the seventeenth century.

The warning notes of the coming controversy began to be heard in the middle of the eighteenth century. Jonathan Mayhew of Boston, breaking with the theology of his time on the whole doctrinal front, the Theodore Parker of his day, Arminian, Liberal Christian, Independent, and Separatist, anticipated the Universalism of Hosea Ballou in renouncing at once the doctrines of the trinity and of everlasting punishment. The forcefulness of his attack on the latter doctrine may be gauged by the heat of his critic and assailant, John Cleaveland of Ipswich. His great influence and popularity throughout New England imply a widespread diffusion of his views and no small following in the churches. His eminent contemporary, Charles Chauncy, kept Boston astir with his sermons and writings in open advocacy of the faith in the salvation of all souls, as well as of the divine unity. The pastor of the First Church was an aggressive Universalist before Murray or Ballou ever scandalized the orthodoxy of the town with their heresies. Still later Jeremy Belknap added himself to the leaders of what Mr. Cooke graphically styles, "the silent advance of liberalism " in the centre of New England's religious thought. 
In Connecticut, Joseph Huntington, an eighteenth century Horace Bushnell, born out of due time, published a work with the stimulating title Calvinism Improved, whose circulation would have set many minds to thinking, had not his pious and evangelical daughter burned up the greater part of the edition. These are but a few of the many prophetic souls who early saw the light of the Larger Faith and followed its leadings.

Such leaders and champions of a great idea convey a hint of large defections from the popular creeds. Such speech must have secured a hearing to match it. This probability is confirmed into a certainty by the outcry that was raised over the heresies thus made public. When Chauncy's pamphlet Salvation for All Souls appeared, a book was published in Connecticut which was announced as "a humble attempt to support the sinking truths of God against some of the principal errors raging at this time." Its preface spoke of the "low state of religion and the awful floods of error" which prevailed, and singled out the prevalent "Origenism (or the doctrine of Universal Salvation) as lying nearest to the root of all the impiety and wickedness now leading the fashion in places of public resort." Such expressions of offended orthodoxy do not necessarily mean any serious breach in the established faith, but they do point to much theological unrest and revolt. When John Murray preached in Gloucester in 1774 , he was surprised to find "dwellers in that remote place" who had embraced the doctrines of his own teacher, James Relly. It was about these days that in four adjoining towns in New Hampshire five pastors of Congregational churches became Universalists, all but one of them being dismissed for their heresy. The marked accessions to the new sect of the Universalists from the Baptist churches is another evidence of the extent and the force of the revolt from Calvinism unimproved. 
It was in the year 1774 that John Murray, speaking after the fashion of this world, "drifted " into New England and found his way to Gloucester, Massachusetts. A more reverent description of his advent would be to call it a providential guidance. The story of this pioneer of organized Universalism in America reads like a spiritual romance, almost a rescript of the story of Jonah the "prodigal Prophet." Like that rebellious servant of Jehovah, he was fleeing by ship from the voice of duty and of God, in great inward depression and gloom, especially repressing in himself the call to prophesy in the spirit of the Larger Faith. Like the son of Amittai, he was removed from his ship by a marvel no less startling than the adventure of the Hebrew, and again set face to face with his mission through the faith of a simple man who persuaded him to deliver his word in the little church he had built in absolute trust that such a preacher would come to it as now appeared. For four years he sought in vain for any group of people who saw the light as he did, until in the port of Gloucester he found " a few persons . . . upon whom the light of the gospel had more than dawned." Here was organized the first Universalist Church in America. It has passed through many vicissitudes, many persecutions at law, many theological assaults, many spiritual depressions, but still lives as "the Independent Christian Society of Gloucester."

The bent of John Murray's mind was strongly Calvinistic, and was shaped by the curious theological scheme set forth by James Relly, of England, in his book entitled Union, the contention of which was that all men have been brought into the favor of God by the righteousness of Jesus Christ, as truly as if each one had suffered and obeyed in his own person. The redemption thus achieved must be honored by the Divine Being, and therefore the salvation of the whole family of mankind is assured. Murray was not an original thinker; he originated no system of theological thought; 
he accepted and proclaimed the ideas of another. This fact enables us to give credit where credit belongs and declare the connection between James Relly and the first organized attack upon the intrenched Calvinism of the New England churches. James Relly made John Murray, and John Murray made the beginnings of the Universalist Church in America, here in New England, on the rocks of Cape Ann. The time was ripe, long before the pacifist Unitarians in the bosom of the standing order were ready to take it by the forelock, when the break should be made with the old theology, and organization and the count of heads be begun, in behalf of the new theology. Such an hour presented itself in the early church, when Christianity had to part from Judaism or else atrophy into a faction of the mother-church. Such an hour recurred when Luther was disfellowshipped and forced to organize his protest and contest its right to be and to spread. The hour struck anew in the eighteenth century, and it found John Murray and a handful of Universalists after his fashion ready to stand for the Larger Faith. For a generation before the Unitarians had found themselves, the Universalists were in the field, organized, enlisted and doing hot work in the firing line for the truth. When the first rally of the Unitarians took place in the Berry Street Chapel in 1820 , this little band had been organized and growing for nearly forty years. Their system has passed; but the harvest from that seed-church is still being reaped throughout New England and the whole land. To Murray also must be assigned the high credit of striking the keynote of modern preaching in his joyousness and triumphant confidence in the glorious outcome of the conflict with sin and its sequences. The mood of modern religious teaching has been a buoyant optimism, its message one of hope and faith, of confidence in the divine resources, of belief in the impermanence of evil. When Murray cried in the wilderness of 
Calvinism, his voice was as of one who brought good tidings of great joy, who published peace, who proclaimed, "Thy God reigneth." It was time for such a herald. Men were heart-sick over the dreary message of God's wrath, of man's depravity and inability, of impending doom and endless wreckage and ruin. This man stood in the pulpit with a heart full of gladness. With him came a new spirit into the heart of American religion.

The work of John Murray had been going on for some thirty years, when a new force appeared upon the field of battle for the Larger Faith. Hosea Ballou, coming to maturity, excommunicated from a Baptist Church, joined himself to the Universalists, and in ten years' time became the scarcely questioned leader of their thinking forces. His reputation spread rapidly throughout New England as a remarkable preacher, and under the contagion of his spirit, the converts to the faith grew rapidly. But more important yet, the very faith itself, under the lead of this masterly and straightforward intellect, was converted from the hybrid orthodoxy of Murray, and planted squarely upon the sound foundations of Broad Church theology, where it has ever since rested. Murray's system was a curious blend of John Calvin and James Relly. It was orthodoxy newly roofed and made tenable to humane and reasonable minds. It was an alteration in the current theology which furnished an excuse for remaining on the premises. But Ballou, through his preaching and his memorable book, $A$ Treatise on Atonement, opened the way for many grateful hearts to new and ampler ideals, to a reasonable and humane conception of God and his moral purposes. In his Treatise is the first assembling of all the points of the liberal theology of the present day, the anticipation of the common doctrines from which, in later years, that wonderful trio of New Englanders, Bushnell, Beecher, and Brooks, preached the old New Eng- 
land theology out of court. The claim is indisputable that $A$ Treatise on Atonement covers every point in the later system which we call " the New Theology," save only its view of the origin of the Scriptures. It taught the unchanging love of God as the supreme trait in the godhead; his eternal fatherhood; man's sonship to God; the mission of Jesus as the reconciler of man to God; the certainty of punishment for sin; and the final salvation of all souls. Mr. George Willis Cooke affirms that it "had small influence on the current of religious thinking outside the Universalist body." Be that as it may, it was the message which reformed the theology of the men who were to reform the thought of the American Church. Whether direct or indirect, its effect was the same. It was the first book to outline in full the principles of the Larger Faith in America. It will yet be recognized as one of the great works of New England's theologians.

It is to be noted that with the advent of Ballou and his followers the policy of the Universalists in New England became more distinctly aggressive toward the ruling forces in the church. Hitherto they had seemed to hope that they might preach their heresy and at the same time retain their standing in the ranks of orthodoxy. Like the Unitarians, whose pacific temper long deterred them from an open break with the standing order, they would gladly have remained under the old standards and maintained the old fellowship. They had not yet realized the "irrepressible conflict" that was impending, nor the implacable hostility they must face. The forces of the Old Theology were bent on war; they had no thought or purpose of compromise. The new heresy was "the abomination of desolation." The doctrine must be extirpated and its adherents plucked out, root and branch. There could be no concord between Christ and Belial; and Belial must be cast forth, with all 
his iniquity. The Universalists of New England were swift to recognize the challenge of opposition, to appreciate its meaning, and to rally all their slender forces for the conflict. The spirit in them was that of Captain Parker at Lexington Green, "If they want a war, let it begin here." Hence, it happened that the first organized body in New England to attack the intrenched ecclesiastical and theological forces of the majority was the little group of religious societies called Universalists.

Let us linger a moment here, in the interests of clearness and historic justice. The Universalists of New England chose the policy of theological militancy thirty years before their later allies, the Unitarians, were forced into the same attitude. That policy included, not merely the rejection of the doctrine of eternal punishment, but the whole "scheme of salvation" as held by orthodox Christians and by the heretical Calvinists who followed John Murray. Nothing could be farther from the fact than the assertion, which amounts to a detraction, that Universalism has been a single-track theology, beginning and ending in the final harmony of all souls with God. It is impossible, in the good providence of God, to put a copyright or a patent upon the truth; because truth is the common right and possession of mankind. But were it possible, and had the early Universalists of New England looked to their selfish interests, two-thirds of the Protestant ministers of that territory today would be paying theological royalties to the heirs and assigns of Ballou and others. After its restatement by Hosea Ballou, Universalism in New England and elsewhere became a system, not a dogma. It dared deny the whole series of cohering misconceptions of the Gospel which was backed by the popular churches - the trinity, the fall of man, the total depravity of the race, the governmental theory of the atonement, salvation by faith alone, and end- 
less punishment. It is the senior Unitarian body in this country, since, twenty years before the Unitarians were organized for their splendid campaign of theological reform, the Universalists of New England were a solid, aggressive body committed to the doctrine of the unity of God. A whole generation before Horace Bushnell pleaded in Connecticut for a more Christian interpretation of the Atonement, these Universalists were standing for a doctrine to all intents the same as his. Seventy years before Beecher and Brooks were winning men to the modern conception of the fatherhood of God, they were suffering theological and social ostracism for their advocacy of the same sublime epitome of the Gospel. The Unitarian statement of "The Things commonly believed among us" - originating, I believe, with James Freeman Clarke - contains a fine phrase, "salvation by character." That, too, was a clear teaching of these early prophets of the Larger Faith. It was to a body of doctrine as broad, as inclusive, as coherent as this, that these pioneers in the campaign against Calvinism consecrated their lives and all their powers. It is an inversion of the facts to call these people the narrow partisans of "one idea." To them, as to their descendants, the doctrine of the final harmony of all souls with God was but the keystone of an indestructible arch, resting on the one side upon the nature of God and on the other upon the nature of man. To change the figure and the point of view, the doctrine of eternal punishment was the vital salient in the orthodox line of battle; if the enemy's front were pierced here, nothing could save it from confusion and defeat. Two great facts in theological logistics the early Universalists consciously or unconsciously felt and acted upon. From the theological point of view, if the force and reality of the dogma of endless punishment could be destroyed, all the associated dogmas would go with it; if, for instance, there were no eternal hell, 
why should there be any need of a substitutional atonement? From the psychological standpoint, it was clear that the surest and quickest way to arouse the interest of the average man was to hold the great controversy to the point at which it bore the hardest upon himself and his own personal destiny. That they seized on these two ideas and made them the basis of their campaign for a half century proves them to have been theological strategists of the first order. Not because John Murray began the warfare so, nor yet because their minds were not large enough to take into account other and most vital matters, but because they perceived that here was the most vulnerable point of the popular faith, they made their "drive" at it early and always and incessantly. The results of the long debate have demonstrated their polemical astuteness.

For more than thirty years after the landing of John Murray the outward growth of the Universalist following was but meagre. At the beginning of the nineteenth century there were about thirty-five societies for the support of the faith, mostly in New England. They were variously grouped in eastern Massachusetts, in lower New Hampshire and Vermont, along the coast of Maine, in and around Providence, and through the country regions of Connecticut. They were somewhat loosely organized according to congregational usage, exceedingly sensitive independencies, too jealous of their liberties to cultivate their unities. In I792 one of these societies reported at a gathering of the faithful that " the brethren of this place seem averse to system, and generally walk as seemeth right to every man." A letter from Newport, Rhode Island, about the same year describes in most ingenuous fashion the extreme of feeling on this subject and the absurd sequences of the policy. "Those at Newport join neither with the world nor with each other. They are afraid of years and of months and of days; and to avoid 
being tangled with what they deem a yoke of bondage, they keep from even the appearance of assembling at any time." These were representative utterances concerning the independency which builds its walls so stout against authority that it shuts out all the vantage of fraternity. For the most part these new Separatists kept as much aloof from friend as from foe, and the long mistake was begun of an extreme congregationalism which permits every parish to do as it may please, with no reference to what its associates are doing or desiring to do. It has taken a century to redeem the denomination from this early error, and the end is not yet. All the way along the years the Universalist Church has been handicapped and hindered by the individualism of its membership and the independency of its societies.

But the parishes and preaching stations throughout New England multiplied and grew, and the instinct to coöperate led to the formation of a few "associations," as they were called, and now and then to the holding of a more important gathering under the name of a "convention." The most memorable and important of them was held at Winchester, New Hampshire, in I803. It was composed of societies represented by twenty clerical and twenty-two lay delegates. The chief business of this convocation and the work for which it will always be remembered, was the adoption of a statement of belief, put forth in the name of the "Churches and Societies of Universalists of the New England States, assembled in General Convention."

The Profession of Belief adopted at the session at Winchester, New Hampshire, A. D., ISO3, is as follows:

Article I. We believe that the Holy Scriptures of the Old and New Testaments contain a revelation of the character of God and of the duty, interest, and final destination of mankind.

ARTICLE II. We believe that there is one God, whose nature is Love, revealed in one Lord Jesus Christ, by one Holy Spirit of Grace, 
who will finally restore the whole family of mankind to holiness and happiness.

ARTICLE III. We believe that holiness and true happiness are inseparably connected, and that believers ought to be careful to maintain order and practice good works; for these things are good and profitable unto men.

This was the famous Profession of Belief, known as the "Winchester Profession." The Profession was the first explicit statement in the form of creed, articles, or profession, of the great fundamentals of what has come to be known as " liberal Christianity" or " the new orthodoxy" or "broad church theology." It was the affirmation of a body of men who had been converted from the Calvinism of Murray to the liberalism of Ballou. They were Arminian, Unitarian, Universalist. The preaching and the influence of Ballou had already swung the majority of those whom they represented to the new theology, in all its essentials. The Profession was the direct outcome of the principles which for a good half century had been leavening the religious thought of the land. It sounded the note of freedom from the standing order of the church and ran up the colors of an independent body, resting on the new doctrines affirmed. It is the document in which the new theology - the theology which starts from the fatherhood of God and proceeds consistently to the final and universal harmony of the moral creationwas first set forth in a creed. It was thus at once the Magna Charta and the Declaration of Independence of the Broad Church in America. It was the assertion of the fundamental truths on which the subscribers planted themselves and it was the proclamation of their intent to claim their rights to a free ecclesiastical life, in the service of those truths. The adoption of this creed was an event of the first importance in the religious history of the country. For it definitely marked the birth of a new theology, the renaissance of the 
primal Gospel of Jesus Christ. It was the signal for organization and for aggression among the friends of the Larger Faith. It was a distinct stimulus to the controversy and rising temperature which at length forced the Berry Street Conference and the Unitarian schism. It was the ensign of the vanguard of the New Theology. It stood for the Universal Fatherhood of God; for man's Sonship to God as typified in Jesus Christ; for the Atonement as the reconciliation of man to God; for the Certainty of the Penalties of sin, here or hereafter; and for the final Harmony of all souls with God. It is one of the great fundamental documents of New England's history. Those whose heritage includes the Mayflower Compact and the Connecticut Charter and Fundamental Orders ought to hold in equal esteem and honor this first creedal statement of the organization which led the struggle for the Larger Faith in America.

Let it be said at this point, lest this claim of priority in behalf of both Hosea Ballou and the Winchester Profession seem to savor of vainglory, that the claim is made in the Commonwealth which prides itself upon Plymouth Rock and Concord Bridge and Lexington Green and Old Ironsides and Harvard University. It is here accounted an honor to have sprung from the forerunners of the world's good, and to keep their memories fresh. It is still counted a fine thing in New England to have inherited, in blood or in belief from the prophets or from the prophecies of law and liberty and to remind men of both. It is equally an affair of filial honor and religious loyalty to remind a forgetful generation of who first lifted up the standards of the Larger Faith in this glorious corner of the universe, and the truths for which they stood in array against the legions of a relentless Calvinism. As long as the sculptured Minute Man challenges the visitor to Concord Bridge, or "'The granite spike that's druv thru Bunker Hill" is cooled by the east winds of 
Boston Harbor, so long you must bear with those who pay honor where honor is due, to the men who set the pace and took the initiative in the conflict for man's emancipation from the tyranny of a false gospel.

The Winchester Profession still stands as the historic and official statement of faith of the Universalist Church in America. It was supplemented in the year rgor by a statement of the Principles of Universalism which the Profession was held to contain. This statement was accompanied by a declaration that "neither this nor any other precise form of words is required as a condition of fellowship, provided always that the principles above stated be professed." That saving clause prevents once for all any narrow and overscrupulous disputes about particular words and phrases, and demands, as a condition of fellowship, only a broad and reasonable agreement as to the great truths held up as the standard of faith and teaching. Thus the spirit of the historic Profession is preserved and a new and perennial lease of life conferred upon it.

One of the features of the eighteenth century Ecclesiastical Affairs, was the long and stubborn struggle of the dissenting sects - and they were many and strange - to secure and maintain their freedom from the standing order, the Congregationalism of New England. The compulsory tax for the support of preaching was not so obnoxious when all were of pretty much the same theological way of thinking; but as differences arose and factions separated themselves from the established churches, the injustice of the enforced support of the state's church and minister, while maintaining religious services and organizations of their own, became an acute issue. Of course it involved the Universalists. John Murray's society in Gloucester became defendants in a long and costly suit at law, which, however, in June, I786, was decided in their favor, and gave them the right to their 
own funds for the support of a minister after their own faith. This decision encouraged them and had a distinct bearing on subsequent cases of the same type. One of these was the famous litigation of Christopher Erskine of Claremont in 1802, who, being "sued for the non-payment of Congregational ministerial taxes, prayed for counsel." The courts gave adverse judgments, but in 1805 the Legislature of New Hampshire passed a statute recognizing Universalists as a distinct sect.

It was for a long time held, as a denominational tradition, that the Winchester Convention in 1803 had for its main purpose the adoption of such a form of church government as should meet the general doctrine held by the courts of New England, that however dissenting sects might differ from the standing order in theological belief, they could not claim exemption from the tax to support the ministry of the Congregational Church unless they could show that they held to a different form of organization and ecclesiastical government. But as the action of the Convention did not furnish such a plan, but left the churches represented practically under a congregational polity; and as the adoption of a different theological creed did not, under these circumstances, relieve them from the claims and demands of the established order, it may be assumed that the object of the Convention was rather to furnish a working system for the good of the churches concerned, than to make a stronger foundation for their legal demands for release from the double support of religious worship which the courts ruled was their duty. Moreover, the Convention issued a long and explicit address to the Universalists in New Hampshire, calling upon them to face the unfavorable action of the courts as " serious, solemn, and awful truths," whose consequences were bound to be dangerous and disastrous to their possessions and their liberty, but calling upon them to stand fast 
in the faith and not "to make a compact with iniquity." This fact conclusively proves that the Convention itself looked for no relief through the adoption of a creed, but sought relief from this crying injustice through other channels. Help came, as was hoped, when the New Hampshire legislature, by the special act referred to, recognized the Universalists as a distinct sect and declared them entitled to the same privileges and immunities as any other denomination. Gradually the disestablishment of the church was effected throughout New England, last of all in Massachusetts, in I834, and, as Williston Walker says, "New England Congregationalism reverted to its original system of voluntaryism."

Every religious movement is subject to its schisms, and the Universalist body had its experience of secession at a very early date. This episode of the denominational history took place in New England. In I8I 7, a debate was begun over the teaching of the Scriptures concerning the duration of the punishment of the wicked, which started in the most friendly spirit but led to heat and bitterness and culminated in the separation of a number of ministers and congregations from the main body of believers in the final salvation of all souls. It was a wholly unnecessary and futile discussion which need not have affected the integrity of the denomination nor jarred its unanimity. It arose from a proposition of Hosea Ballou, then of Salem, to Edward Turner of Charlestown, to discuss with him the question whether the Scriptures teach the doctrine of the punishment of the wicked in the future life. Ballou's proposal was peculiar in his offer to take either side of the question, a fact which indicates that at this time the doctrine of no future punishment did not hold a very important place in his theological system. Apparently the purpose was to engage in a harmless exercise in polemics. Probably, if the debate had ended with 
the arguments of the two principals, very little would have been heard of it. But the contagion of dispute spread among some of the younger and less judicious of the brethren, and much mischief ensued.

Among the early Universalists in America the doctrine of a limited term of punishment for the wicked in the future was not questioned. John Murray inherited the doctrine from his spiritual father, James Relly. Elhanan Winchester was of the same mind, and was even ready to suggest a matter of fifty thousand years as a possible limit. It is admitted that the Philadelphia Articles of Faith, adopted as the creed of the convention of churches in I790, had the assent and personal revision of Benjamin Rush, a disciple of Elhanan Winchester. Hosea Ballou himself, in the earlier period of his thinking, made no objection to this teaching. Probably the major part of the preachers and laity of that day assumed that the penalties for sin held over into the life to come. About the year I793, Abel Sargent of Pennsylvania became a vigorous defender of the doctrine of no future punishment, and Caleb Rich of Massachusetts, from whom Ballou received his first instruction in the faith, "openly contended that all the (evil) consequences of $\sin$ were confined to the present life." For more than two generations this type of Universalism waxed stronger and asserted itself with great vehemence. It was wholly aside from the main contention of the denomination to lay such stress upon this minor point of theological affirmation. Ample room was afforded in organization and in creedal statements for both parties to stand together. As early as I79I, when the Philadelphia Convention was asked to define the position of the Universalist Church upon the question of future punishment, it made answer in this wise:

Unbelievers do die in their sins; such will not be purged of their sins or unbelief by death, but necessarily must appear in the next 
state under all the darkness, fear, and torment and conscious guilt, which is the natural consequence of unbelief in the truth. What may. be the duration or degree of this state of unbelief and misery, we know not. But this we know, that it hath one uniform and invariable end; namely, the good of the creature.

That ought to have been a broad enough platform for all parties. But there are certain minds whose interest centres in details and who insist on an orthodoxy as inflexible in its by-laws as in its constitution. It was the men of this temper who swept the Universalist body away from its original and tolerant position and committed it for more than a halfcentury to a partisan attitude. Ballou and Turner soon finished their dialectical diversion. In the words of Dr. Fisher, "The debate ran on in the shape of fourteen letters that were published in the denominational paper, the Gospel Visitant." Then the contest closed, not because either side surrendered, or claimed the victory, but because a merciful Providence ordained that the Visitant should cease to be published. But the dogs of controversial war were unleashed, and were bound to run their course.

The most conspicuous leaders in the long wrangle, both theological and ecclesiastical, which ensued, were two clerical Hotspurs, Thomas Whittemore, editor, preacher, and born controversialist, and Adin Ballou, restorationist, abolitionist, prohibitionist, communist, spiritualist, pacifist - one of the most remarkable souls that New England has produced. Others of weight and ability ranged themselves on either side - Paul Dean, the assistant of John Murray at Boston, Edward Mitchell of New York City, Edward Turner of Charleston, one of the original disputants, these standing with Adin Ballou; while Walter Balfour, a writer of power and note, Hosea Ballou, and the majority of the younger men of the period, formed the following of Whittemore. The controversy that ensued was neither educational 
nor edifying. It became a riot of newspaper communications and pamphlets, " appeals" and "replies," "inquiries" and "declarations," personalities and recriminations, with the maximum of heat and the minimum of light. Much bitter feeling was stirred and the usual issue of such undisciplined differences befell. In I83r, a convention of Restorationists - ministers and delegates - was held at Mendon, Massachusetts, and a separate organization formed comprising about twenty clergymen and an uncertain number of laymen. The seceding body had a short life, and in I84I, held its last meeting. The Restorationists as a sect appear no more.

But time and reason bring their strange and unlooked-for revenges and compensations. "The blood of the martyrs is the seed of the church," and the discomfiture of the Restorationists in this campaign was in a few short years offset by the swing of practically the whole denomination back to the original position of the founders, until today the entire Universalist church is frankly of the conviction that not only do we "get our punishment as we go along" to revive a theological colloquialism of the former days - but that it may go a long way with us into the future.

In 1878 , the Universalist ministers of Boston and vicinity, after weeks of deliberation, adopted a statement concerning the views then prevailing, whose closing paragraphs are as true today as then, and may be said to have closed for all time this division of faith in the church:

In respect to death, we believe that however important it may be in removing manifold temptations and opening the way to a better life, and however like other great events it may profoundly influence man, it has no saving power. Salvation, secured in the willing mind by the agencies of divine truth, light, and love, essentially represented in Christ - whether effected here or in the future life, is salvation by Christ, and gives no warrant for the imputation to us of the "death and glory" theory, alike repudiated by all. 
Whatever differences may exist among us in regard to the future, none of us believe that the horizon of eternity will relatively, either largely or for a long time, be overcast by the clouds of sin or punishment, and in coming into the enjoyment of salvation, whatsoever that may be, all the elements of penitence, forgiveness, and regeneration are involved. Justice and mercy will then be seen to be entirely at one, and God will be all in all.

In justice to Hosea Ballou and as a part of any fair statement of the theology of the Universalists of New England, it ought to be said that Ballou's views upon the future did not by any means form one of the cardinal points of his theology. He himself protested against the prominence given them, as well as against the misrepresentation they suffered. His contention was twofold. First, that punishment is contemporaneous with sin, begins with it, and continuously accompanies it. Secondly, that the changes in the environment and condition at death will so influence the soul, as to overcome its revolt against the Divine and bring it to a quick penitence. He would never admit that he believed death to be the saviour of man; and he resented the imputation that he taught, as Channing charged, that death has power to purify the soul. He maintained that the only difference between himself and other believers in the Larger Faith was a difference as to the intensity of the means of grace and the speed at which they would operate. To put the whole matter in a word, Ballou seems to have conceived of the beginnings of the life after death as resembling a continuous revival season, whose tense conditions and impressive experiences could not fail to change wholly the temper of the sinner and to overcome the perversions of his will. In the words of his biographer, Dr. Safford, " he believed that the soul on arriving at immortality, with earthly and sinful desires all gone, will immediately behold such heavenly illumination as will cause a glad forgetfulness 
of the things behind and a pressing forward to the things before. This result of glorious salvation, however, he believed would be effected by no arbitrary means or interference with the individuality or the free choice of the souls, but by the moral power of the Father's all-conquering love."

It is no easy task to set forth the traits of one's ancestors either in the flesh or in the faith. But so much misconception and distortion of the character and spirit of the Universalists of New England has controlled, almost unquestioned, the popular mind, that the estimate of sympathy and a common point of view will do no harm. It was inevitable that the heretics from the ancient faith should suffer aspersion at the hands of those whose cherished dogmas they dared to doubt. It was equally certain that the early attitude of those whom they opposed determined the kind of warfare which was adopted. Theological heresy was still counted one of the cardinal sins, when the pious people of Gloucester proposed to run John Murray out of town. Plainly, if the Universalist were to exist at all socially or ecclesiastically, he must stand up in his own defence. He must become a militant. This was the more imperative in the case of the plain man of the people, such as most of the Universalists were. He who has little wealth, small political influence, scant education, no assured social standing, if he becomes a heretic, must look to his fighting abilities. He shall have use for them. Here was a reason why the Universalist and Unitarian temper and policies in the advancement of the truths they held in common, varied so widely. The former were liable to social ostracism and to business hardships on account of their opinions. They were branded as atheists and travellers toward the pit. It was deemed disreputable to attend their meetings or to read their books. Their services were obstructed and their characters assailed. Little wonder that their resentment was roused and the 
sense of injustice intensified their hostility toward the system they were opposing. Their Unitarian allies, on the other hand, were secure in their social position, were reassured by the culture and learning of the clergy who led them and the influential laymen who gave weight to their movement. With no social or business handicaps, nor any serious rupture with old conditions, the Unitarian temper was less heated in controversy, less aggressive in policy. As a matter of fact, the Unitarian of the early century preferred the fellowship of the men and churches from whom he was sundered by all his theological convictions, but who were his social intimates, co-graduates of Harvard and Yale, and fellowmembers of the bar, the bench, and the board of trade, to affiliation with the people who stood next to him in religious conviction. This condition was also one of the reasons why there was so little coöperation between the two bodies. The difficulty was more social than anything else. The old New England of the post-revolution days had a good deal of the caste spirit still surviving from the colonial times.

Another of the effects of the policy, aggressive and rebellious, of the new sect, was to attract to its ranks all classes and conditions of ethical and religious malcontents, a host of those who had any grievance against the established churches, and make the denominational standards a rallying-point for whatever was anti-orthodox. These recruits brought no sympathy with the deep religious spirit of the new faith, they had no share in its spiritual aspirations or observances. They throve on the air of controversy and when they betook themselves to the pages of the Scriptures, they opened them only to bring forth chapter and verse that should confute and confound him that was of the opposite part. Many of the societies which they formed were hardly more than theological clubs, to afford a hearing for ministers whose sole function was to batter at the walls of the Calvinistic Bastile. 
That New England Universalism was able to purge itself of these unwholesome and unwelcome elements was proof of its essential soundness and spirituality. But their indifference to the deeper religious implications of the faith, their aversion to the emotional elements and factors of the religious nature, their failure to grasp the new motive to missions which so far transcended the older, - all these limitations and defects constituted a serious hindrance to the right development of the spirit of the founders and real prophets of the church.

For from the beginning until now, the heart of New England Universalism has been aglow with a true religious life. The genius of that crusade against the theology of decrees, depravity and damnation, has always been religious. It has kept to the road in which it was started by the perfervid Murray and the devout and reverent Ballou. Despite the shortcomings of those who allied themselves with it for nothing but the fight against orthodoxy, it has kept faith with the fathers in the maintenance of its Christian standing and spirit and expression. It has grown in grace and in the knowledge of our Lord and Saviour Jesus Christ; it has patiently sought the profounder meanings of its own high calling; it has learned its own relation to world-evangelization; it has striven against the tides of a material age to a more prayerful and spiritual temper and consecration; it has trained its young life in personal loyalty to the Christ; it has responded almost as a unit to every real reform; it has been quick to interpret the meaning of the new call upon the churches to champion the great social ideals which shall recognize the common origin, the common interests, the common destiny of the whole human race. Its faith has been more than a theological idea. It has been vitalized by godly living. Its record has been more than a history of controversy. It is a sum of saintly lives. Every church 
that bears its name has its separate roster, and from the little shrines in the hill-towns of New Hampshire and Vermont to the great churches in the metropolitan centres, there are memorials of these saints of the new and Larger Faith, the apostles of the rising truth. They are its epistle, known and read of all men, bearing witness to the steadfastness with which the church of their love and loyalty has grown from the principles of the fathers to the fuller interpretation of the sons.

Of the outcome of this century of debate and controversy, it remains to be said that it gives these heirs of the men who are responsible for it nothing but solemn satisfaction and a deep gratitude to God. It has been the privilege of our time to see the great contentions of these reformers finding acceptance among the thinking people of all sects and denominations. The harsher doctrines of election and reprobation, of infant damnation, of total depravity and the judicial theory of atonement have generally been repudiated and are no longer recognized as entitled to a place in a reputable modern creed. Multitudes have come to hold the doctrine of the trinity in a fashion so vague as to be scarcely distinguishable, save in its phrasing, from Unitarianism. Dr. Chapin used to declare that the modern doctrine of endless punishment bore the same relation to the old dogma as a harmless domestic cat to the aboriginal tiger. The whole religious climate has been so modified that the harsher dogmas can no longer live in New England. As a necessary result of this evolution of theological sentiment, it has come to pass that those who have striven for this new status are no longer the objects of persecution, hardly even of suspicion. Universalism has served its apprenticeship as a heresy, and now finds itself in good standing among the acceptable interpretations of the Gospel. Each in its turn the several churches have outlived the stigma of heterodoxy and achieved the 
standing of orthodoxy, and now it is the turn of the Larger Faith. The spirit of the new times is upon us all. The passing of the old bitterness, the softening of theological asperities, the advent of the day of fellowship and of cooperation, have abated the old animosities, and replaced them with a finer spirit of tolerance. For the generous share which this church has had in the glorious consummation, we who are its sons are proud and grateful. We can devoutly say, as we survey the past out of which we have come, and look into the future which invites us, "These all having obtained a good report through faith received not the promises, God having provided some better thing for us, that they without us might not be made perfect."

What those better things may be no man can prophesy. But they are certain to include the merging of effort in the new issues which challenge all Christian men, and the submerging of old differences, which grow less and less as the larger temper pervades the life of society. It does not need to imply the loss of identity, nor the weakening of loyalty to the standards about which cluster the hallowed memories of a great conflict for the freedom and the joy of a nobler faith. If with the lapse of time something of the old distinctiveness must also pass away, it will only be as the old New England characteristics have been lost through their wider diffusion and assimilation over a wider area and through a vaster constituency. New England has escaped from its corner and pervaded the half of a continent; Universalism has overflowed its denominational dykes, and now irrigates the sentiment of all the churches. What crops shall be harvested from the new soil we know not. The future, like the past, is with God. 



\section{VIII}

\section{THE SWEDENBORGIANS}

WILLIAM L. WORCESTER 



\section{THE SWEDENBORGIANS}

THE beginning of the New Church (commonly known as 1 Swedenborgian) in America is associated in an interesting way with the founding of the nation. The Rev. Jacob Duché, a minister of the Church of England, and rector of Christ Church in Philadelphia, has been called the first New Churchman in America. When the Continental Congress first met in I774, Duché was called to conduct an opening service and to make the first prayer in Congress. John Adams in a letter to his wife wrote of the great appropriateness of the Scripture that was read, and of the fervor and ardor, the earnestness and pathos and eloquence, of the prayer, in which Duché prayed for America, for Congress, for the Province of Massachusetts Bay, and especially for Boston, of whose bombardment they had heard on the previous morning. ${ }^{1}$

The same Jacob Duché was instrumental in planting the New Church in New England. Living for a time in practical banishment in England, "not being willing," so the record reads, " to go all lengths with the Revolutionists," he there interested the Rev. William Hill in the doctrines of the New Church, and this man made two visits to America, in I794

1 It is probable that the Rev. Jacob Duché must yield the distinction of having been the first to advocate publicly the doctrines of the New Church, in America, to James Glenn, of whom we shall presently speak. There is evidence that before his departure for England, in I 777, Mr. Duché had in his library a set of Swedenborg's works in Latin; but the first direct evidence of his being acquainted with the contents of the volumes is during the early part of his stay in England. Mr. Duché returned to America in 1790 , but in the meantime James Glenn had visited the country in 1784 , and given public lectures on the doctrines. See Rev. Jacob Duché, D. D., by William B. Hayden, New Jerusalem Magazine, Vol. XXXVIII, pp. 496, 561, 615; also The Rev. Jacob Duché, by Charles Higham, NewChurch Review, Vol. XXII, pp. 210, 404. 
and 1796 , for the sake of spreading a knowledge of the doctrines, the second time remaining permanently in this country. Mr. Hill is described to us by a lady whom I well remember. ${ }^{1}$ She met him at the home of Mr. Andrew Craigie, in Cambridge, now known as the Longfellow house, Mr. Craigie being one of those who became interested in the new teachings. It appears that Mr. Hill had a special desire to find a reception for the New Church at Harvard College, and he gave to the College Library Swedenborg's Arcana Coelestia, in eight large Latin volumes, and perhaps other works of Swedenborg. These books, about twenty years later, were the means of awakening the interest that $\mathrm{Mr}$. Hill had hoped for. A group of strong men in the class of I8I8, with others who were in college at the same time, became interested in the doctrines through the books given by Mr. Hill, and were among the founders of the organized New Church in New England.

One of this group of students was Thomas Worcester, whose father, Noah Worcester, had broken away from Calvinism, and had already exerted an influence upon religious thought in New England by his liberal views as published in his Bible News of the Father, Son, and Holy Ghost, and as first editor of the liberal magazine, The Christian Disciple. Noah Worcester is even better known for his tract, $A$ Solemn Review of the Custom of War, which is still in active service, and for his pioneer labors in the cause of peace. Thomas Worcester, son of Noah, had learned of Swedenborg's works through an older brother, Samuel, and had heard also of the ArcanaCoelestia given by Mr. Hill to the College Library; and in $18 \mathrm{I} 6$, he returned to college as a junior, with the purpose of finding and reading the work. I quote his own account of his experience in finding the books:

1 Early Recollections of the New Church in Boston, by Miss Margaret G. Cary, New Jerusalem Magazine, Vol. XXX, p. 39r. 
Upon my return to college, after I had begun to read Swedenborg, I went to the library the second time to see if I could find any of his works. The librarian looked into the catalogue again, and found the alcove and shelves where they ought to have been, but they were not there. Then we began a thorough search. We looked through the whole library, in place and out of place, but could not find them. Then we began to think of other rooms. At that time the library was in the second story of the west end of Harvard Hall. In the east end was a large room, called the "Philosophical Room," and between this room and the library was a small room, which for want of a better name was called the "Museum." It was filled with rubbish, old curiosities, cast off, superseded, and obsolete philosophical apparatus, and so forth, all covered with dust. We could see no reason for hunting here, except that we had hunted everywhere else, without finding what we wanted. There was a long table in the room. Upon it, and under it, were piles of useless articles; and beyond it were shelves against the wall, where various things were stored away. On the under shelf, as far out of sight as possible, I saw some books. I told the librarian, and he went round and worked his way until he got at them, and found that the large books were volumes of the Arcana Coelestia. There were also several other works of Swedenborg, all of them covered with dust. I immediately got an order from President Kirkland, giving me authority to take the books and keep them in my room; and this I did for the rest of my college life. By what means or for what purpose these "Heavenly Doctrines" were cast out of the library of Harvard College must be left to conjecture. Of the fifty thousand or sixty thousand volumes then belonging to the library, these were the only ones that were treated in this manner. The fact seems to represent the state of the New Church at that time (Biography of Thomas Worcester, by Sampson Reed, pp. I7, I8).

The group of Harvard students who became interested in the New Church through these volumes rescued from oblivion in the College Library were Thomas Worcester, J. H. Wilkins, Warren Goddard, William Parsons, and Sampson Reed, all of the class of I8r8; Theophilus Parsons (later Dane Professor of Law in the Harvard Law School), Caleb Reed, T. B. Hayward, John Angier, Nathaniel Hobart, 
and T. G. Worcester, students in the classes of ${ }_{1} 8_{15},{ }^{\prime}{ }_{7}$, '20, '2 I, and '23.

But earlier than this awakening of interest among Harvard students, there had been a beginning of interest in the doctrines of the New Church among a few men and women in Boston, strengthened by the influence of Mr. Hill, but dating from a few public lectures given in Boston in 1784 by James Glenn, a Scotchman, who has already been referred to as probably the first to advocate publicly the doctrines of the New Church in America. Mr. Glenn also lectured in Philadelphia, and sowed seeds of the New Church among the native Indians in Demerara, British Guiana, seeds which are still growing and bearing fruit. The few interested persons in Boston began in I8I 7 to meet regularly for reading and study of the Scriptures and the doctrines of the New Church; and this little group, soon strengthened by the Harvard students, became the nucleus of the Boston Society of the New Jerusalem, which was organized August 15, I8I8, and incorporated by the Legislature of Massachusetts in February, I823 - the first organized body of the New Jerusalem in New England. Societies had already been organized in Baltimore, Philadelphia, Cincinnati, and New York.

It is perhaps impossible for us in this day of freedom and tolerance to realize fully the difficulties within and without which beset these pioneers of the New Church a hundred years ago. In part their hardships were the same that were experienced by the early Universalists and Unitarians, who rebelled against the standing order, and were at that time waging war with the Calvinism so strongly intrenched in New England. Equally with these liberals, the New Church was at war with the old-fashioned Calvinism and its doctrines of predestination, vicarious atonement, and salvation by faith alone. But on the other hand it was almost equally 
at variance with the liberal bodies. Its position was lonely in the extreme, - a mere handful of people, commonly regarded with suspicion, misunderstood, treated with contempt and ridicule, in not a few cases cut off from association with relatives and former friends. Thomas Worcester once told me that in the early days of his ministry in Boston there was hardly a respectable minister in the city who dared to be civil to him. And when a school was opened for the children of the church, it was in part to protect the children from the treatment which they received in other schools. Yet it was not altogether fear of personal rebuff which led the first members of the New Church in Boston to meet privately, and a little later, when services were established, to question seriously whether to invite the public to their meetings. They could not bear to see things, which to them were sacred and more dear than life itself, subjected to ridicule. It is recorded that at one of the religious meetings, a Christmas service, shortly before the organization of the Society, the little group were so disturbed by the presence of a single stranger, Miss Hannah Adams, who came evidently out of curiosity, that they could not carry out the exercises as planned, and limited the service to a Scripture reading. ${ }^{1}$ If it is true, as is often charged, that the members of the New Church are backward in announcing the doctrines which they hold, in public and in private, it may be in part a natural consequence of the conditions which surrounded them two generations ago. They may have kept a certain reserve and timidity after the cause for it has passed.

This is not the whole story; there is a brighter, happier side to the picture; and as an early instance of friendliness to the New Church, let us record at once that at the first

1 Address before Boston Society, by Sampson Reed, New Jerusalem Magazine, December, $1 \delta_{37}$. 
observance of the Communion by the Society after its organization, in $18 \mathrm{I} 8$, the plate for the service was lent them from King's Chapel. ${ }^{1}$

Before going forward with our narrative, it seems necessary to describe briefly the writings of Swedenborg and the doctrines there set forth, which appealed to a few persons with such convincing power and were so earnestly condemned and feared by others. We need to know what the New Church represents in order to understand its relation to the religious thought and life of New England a hundred years ago and since that time.

Emanuel Swedenborg lived and wrote in Stockholm, Sweden, during the provincial period of New England. He was born in Ió88, and died in I 772 . He is best known as a man of science and a philosopher, the last few years having witnessed a marked revival of interest in the man and his science, which is finding expression in the publication of a new and sumptuous edition of his scientific works by the Royal Academy of Sciences of Sweden. If you glance at the volumes written by Swedenborg, as they stand on the shelves of a library, you are amazed at their amount and the industry which could have produced them. If you arrange the volumes chronologically, you note an interesting sequence in the work. The earlier books are scientific and philosophical. The first of these deal with mathematics and the mineral kingdom. Large volumes treat of the mining and smelting of copper and iron; and it will be remembered that Swedenborg's official position was that of Assessor in the College of Mines, a member of the committee in charge of the mining interests of Sweden. Other volumes deal with the origin of forms and forces. It is here, in his Principia, that Swedenborg announces his theory of the nebular origin

1 Reminiscences of the New Church in Boston, by H. G. Foster, New Jerusalem Magazine, Vol. XXXI, p. I6I. 
of the solar system, similar to the theory of Kant and Laplace, but antedating the announcement of the theory by Kant by twenty-one years and the announcement by Laplace by sixty-two years. During this period of interest in mechanics and abstract science, Swedenborg amused himself with many inventions. A list of inventions in a letter of $\mathrm{I}_{7} \mathrm{I}_{4}$, includes several which have a decidedly modern sound; a submarine, a machine gun, a mechanical musical instrument, a flying machine, and a method of ascertaining the desires and affections of the minds of men by analysis.

Glancing along the row of volumes, we pass from mechanics and metallurgy to the study of the human body, undertaken with the avowed purpose of coming through knowledge of the body to knowledge of the soul. To this group of books belong seven or eight volumes, representing thorough study of the physical organs and functions, and especially of the brain. In these volumes discoveries of modern science are anticipated, not always proved, by the modern laboratory method, but stated confidently on rational grounds. The discussion passes over the border from physiology to psychology, showing the author's eagerness to be reaching the knowledge of the soul to which the whole work was directed. Here also he demonstrates that the way of advance in knowledge from the physical to the spiritual is by recognition of the correspondence between higher and lower forms of life, and of influx from the higher into the lower. The divine Word, though beyond and above the range of study yet attempted, is referred to with reverence and almost with awe, as the divine statement of the true order of social life and individual life which is reflected in the order and the unity of mutual service ruling in the physical body.

Swedenborg had now come as near to a knowledge of the soul as he could come from the side of natural science. There 
followed a short transition period in which he was preparing with all thoroughness for study of God's Word; and then with a clear conviction that he was called by the Lord to renounce all worldly ambitions and to apply himself to this sacred task, he began his great Bible studies. The first of these that Swedenborg himself published was the Arcana Coelestia, a study of Genesis and Exodus. He was engaged upon this work eight years, and published it in as many volumes. Later he made two studies of the Book of Revelation, only one of which he himself published. These Bible studies, made as Swedenborg himself believed under special illumination from the Lord, constitute the larger part of his theological work. The order of the divine life and the true order of human life unfolded to him in the Scriptures, and the nature of this order, was made more clear by conscious association with angels and with the order of heaven in which they live. As the study of the Lord's Word advanced, the principles of this true order, this true Christian life, grew clear, and crystallized out in short doctrinal works. A group of such works follows each of the great Bible studies. After the Arcana Coelestia, were written and published Heaven and Hell, The New Jerusalem and its Heavenly Doctrines, The Last Judgment, and some smaller works. After the first study of the Book of Revelation were written The Doctrine of the Lord, The Doctrine of the Sacred Scripture, The Doctrine of Life, The Doctrine of Faith, The Divine Love and Wisdom, The Divine Providence, The Doctrine of Charity, with several smaller works; and later followed Conjugial Love, and finally a gathering up of doctrine in systematic form in The True Christian Religion. Let it be remembered - a fact demonstrated by the order and relation of the books that Swedenborg's theological work was a work of Scripture exposition, and that the doctrines which he advanced crystallized out of the study of the Bible. And this accords 
with his own declaration that nothing of the doctrine of the New Church was given him by any angel, but by the Lord alone, while he read the Word. ${ }^{1}$

It is necessary further to state briefly the doctrines which Swedenborg taught from the Word, and which were seeking a home in the religious atmosphere of New England. The essential doctrines are sometimes stated by Swedenborg as two; the acknowledgment of the Lord, and a life of charity, which is a life of obedience to the Ten Commandments; and sometimes as three (subdividing one head of the briefer statement): the acknowledgment of the Lord, the acknowledgment of the holiness of the Word, and the life of charity. A few words in explanation of each of these three heads.

By acknowledgment of the Lord, Swedenborg means the recognition of the Lord Jesus Christ as God with us; an acknowledgment of the mind as the nature of the Lord and his relation to us is rationally explained, and an acknowledgment of the heart as his presence and saving power are experienced in life. From the day when the God of infinite love made men, he had revealed himself to them according to their need; and when men were so far under the power of evil that only the immediate divine presence could stem the tide, he came to them. The Gospel account of his coming is accepted as literally true. The divine life breathed upon the virgin mother and took to itself from her, and so from the human race, a nature like their own. In this nature God could be with men where they were; that nature could be tempted in all points like as we are. In temptations more grievous than we can know, he overcame every form of evil, and extends his saving power to us. This was redemption. The work that he did for all mankind we see in miniature in that scene on the shore of Galilee, when the Lord cast out the devils from the man possessed, so fierce

1 True Christian Religion, No. 779. 
that no man could bind or tame him, and he was found sitting at the feet of Jesus, clothed and in his right mind. It is a picture of the redemption wrought for all mankind. Men were free, with his help, to live well if they would.

But what did it amount to, if the Saviour presently went away and left mankind as helpless as before? He did not go away: "Lo, I am with you alway," was his promise. By the Lord's combats with evil and his victories, his human nature was glorified, to use his own word. All that was imperfect, all that was finite and limiting in his humanity was gradually removed, replaced by the divine, till in him dwelt all the fullness of the Godhead bodily. It is to this human nature glorified that Swedenborg applies the name, the Divine Human. In Jesus Christ glorified is the trinity of Father, Son, and Holy Spirit. The acknowledgment of the Lord is the recognition of this very present Helper, and dependence upon him in meeting the temptations and the duties and pleasures of every day.

By acknowledgment of the holiness of the Word, Swedenborg means the recognition that the Sacred Scripture is divine and is the means, as we read it reverently, of holding us in the divine light and power. The divineness of the Word does not necessarily imply that it is historically true in every statement of history or of science, nor ideal in every moral precept; many things in the letter of the Word, like the language in which it is written, were taken from the imperfect minds of men, else it could not have been received and preserved by them; but the Word is divine because everywhere within the letter which killeth is the Spirit which giveth life. Everywhere in the Word, even in every line, there is deeper meaning relating to the spiritual life of every man, and inmostly to the Lord. Incidents of the Scripture narrative are local and temporary in form, but they are universal in their deeper meaning, applying to all men, in 
all places, at all times. Some precepts of the Word may in their literal form become obsolete, but they are in their deeper meaning forever true and full of divine life and power. "Heaven and earth shall pass away (human states and conditions are forever changing), but my Word shall not pass away."

The key to the deeper meanings of the Word is given by Swedenborg in the science of correspondences, which he foreshadowed in his philosophical works; a science as broad as natural science itself, for it studies all natural things to recognize the human and divine forces which they embody and express. The study puts one in sympathy with the wise ancients, who read deep lessons of life in nature and who spoke and taught in parables. Applied to the Scriptures, it shows them to be divine parable, containing exhaustless lessons of divine and human life.

It will be seen that this doctrine of the infinite life and spirit within the letter of the Word gives a new test by which to determine the canon of Scripture. Certain books commonly included in the canon, notably the Proverbs and Job in the Old Testament, and the Acts and Epistles in the New, as judged by this test cannot be regarded as strictly of the Lord's Word. Questioned by friends about the writings of the apostles and Paul, Swedenborg replied that they are good books for the church, insisting upon the doctrine of charity and its faith as strongly as the Lord Himself has done in the Gospels and the Book of Revelation; that it was necessary that doctrinal matters should be presented in the direct manner of the Epistles, but that they are written in a different style from the Word, and have not the infinite depth of meaning. Swedenborg often quotes Paul in support of points of doctrine. ${ }^{1}$

Finally, the third head of Christian faith declared by Swedenborg to be essential: the life of charity, or what is

1 Letter to Dr. Beyer. Documents, No. 224. 
the same, a life of obedience to the Ten Commandments, recognized as laws of God. The meaning is, that Christian life consists in repenting of evils and desisting from evils, which are forbidden by the Commandments, and this not merely from policy or because common opinion or civil law requires it, but in obedience to God, and in reliance on his help, and then in doing good for his sake. This motive in resisting evil and doing good is the only motive which goes to the root of the matter, removing not only the wrong actions but the desire and the thought of evil: this motive alone can do good works which are free from the defiling spirit of self-trust and pride.

These, in the briefest possible phrase, are the doctrines which crystallized out of Swedenborg's Bible studies, and were presented by him, with proofs from Scripture and from reason in his doctrinal works. This statement seemed necessary to enable us to understand the relation of the New Church to its environment in New England a hundred years ago, and its relation to the changes of religious atmosphere in New England since that time.

Thus prepared, we go back to the establishment of the Boston Society of the New Jerusalem, in I8I8. Thomas Worcester was at that time chosen reader: he was ordained as pastor of the Society in 1828 , and held the position till I 867 , a period of service of nearly fifty years. In 1859 , the Rev. James Reed became assistant minister of the Society, and is its pastor still, his term of service now covering fiftyseven years. Since I902, Mr. Reed has been assisted by the Rev. H. Clinton Hay, as associate pastor. The long pastorates well illustrate the even tenor of the way which the Society has followed. It met in several halls for a time and built its present church on Bowdoin Street in 1844-45. The membership of the Boston Society is now reported as four hundred and seventy-three. It must be remembered 
also that several societies in the neighborhood of Boston are in fact offshoots of the church in Boston. This is true of the societies in Waltham, Newtonville, Brookline, Roxbury, and Cambridge, which now have an aggregate membership about equal to that of the parent society. Societies of the New Church also exist in nine other Massachusetts towns: Abington, Bridgewater, Brockton, Elmwood, Fall River, Lancaster, Mansfield, Springfield, and Yarmouthport. These Massachusetts societies, together with societies in Providence, R. I., and in Manchester and Contoocook, N. H., are united as the Massachusetts Association of the New Church, and this Association joins other Associations in other parts of the country and Canada to form the General Convention of the New Jerusalem in the United States of America.

It may be of interest to speak briefiy of the origin of the group of societies in Abington, Bridgewater, Brockton, and Elmwood, for these all owe their beginning to the influence of one man, the Rev. Holland Weeks. Mr. Weeks was pastor of the First Church of Christ, in Abington, an able Congregational minister. About $\mathrm{I} 8 \mathrm{I} 8$, at the time the society was formed in Boston, Mr. Weeks became interested in the doctrines of the New Church, and preached them. He was soon called to account, and was tried by a council of churches in I820. The council found that Mr. Weeks did not hold the generally received doctrine of the resurrection of the body, but believed in an immediate spiritual resurrection; that he did not hold the doctrine of three persons in the Godhead, nor the orthodox doctrine of the atonement, but believed in a Trinity subsisting in Him, " in whom dwelleth all the fullness of the Godhead bodily"; that he held that all prayer should be directed to Christ as God, clothed in a divine body and a human form; that he believed that as "the earth abideth forever," the sun and moon will continue to rise and set, as they do now, to all 
eternity; Mr. Weeks had replied to the charge on this point simply in the words of Ecclesiastes, "I believe that 'one generation passeth away, and another generation cometh; but the earth abideth forever" "; that he had read Swedenborg's treatise on sexual evils, in connection with the preceding treatise on conjugial love, and found nothing in it which, as he understood it, he disapproved; he found the teaching to exalt conjugial love as eminently pure and holy and to condemn the evils.

Let me say, in passing, that the charge of teaching a doctrine leading away from the purity of marriage, which was made with other charges against Mr. Weeks, and which has occasionally been made against the New Church, rests on the grossest misunderstanding of its teaching. I believe that there is not in the world a doctrine which exalts the purity and sanctity of marriage as does the doctrine of the New Church; or which shows so clearly the evilness of all impurity of act or thought or feeling; or which leads so directly to the divine help needed to live up to this high standard. This I solemnly affirm, and I should not fear to maintain it before any fair-minded tribunal.

The council in Mr. Weeks's case further contended, at length, in its report that it is unreasonable to ask men to give serious attention to the teachings of Swedenborg, when their authority has not been attested by convincing signs. Mr. Weeks was dismissed from the Congregational Church. The interest awakened by him gave rise, as stated, to four NewChurch Societies in Massachusetts. Mr. Weeks entered the ministry of the New Church, founding societies in Detroit, Mich., and Henderson, N. Y., and did missionary service, frequently, as the record states, addressing audiences of twelve hundred to fifteen hundred persons.

The Weeks trial has a broader interest, as illustrating the attitude of New England Calvinism toward the doctrines 
of the New Church a hundred years ago. The editorial comment of the Boston Recorder of September 2, 1820 , in printing the account of the trial is' possibly a still truer reflection of popular opinion. It refers to the strenuous efforts made in various sections of the country to give currency to Swedenborgianism. "Not that we much fear," says the editorial, "the extensive prevalence of a system so much better suited to the age of darkness long since past than the present." Grouping Swedenborgianism with Socinianism and Universalism, the editorial adds, "It becomes us to weep rather than smile at aberrations of mind which involve consequences so tremendous to the individuals given up to those strong delusions - so injurious to the honor of Christianity - so fatal to thousands who find in the divisions of Christians an argument against the reality of religion itself." It should be said, that both the report of the council and the editorial are kind in their personal references to $\mathrm{Mr}$. Weeks. ${ }^{1}$

We may put with the Weeks trial one other case, that of the Rev. Baman N. Stone and the Society of Fryeburg, Maine, and this at a much later date, in 1877 . The doctrines of the New Church were first made known in Maine by the Rev. Dr. William Jenks, a Congregational minister in Bath. Seven years later another advocate appeared in Gardiner, whose interest had been awakened through the Rev. William Hill, who gave the books of Swedenborg to Harvard College. Societies were formed in Bath and Gardiner, that in Bath developing considerable strength. In I840, the Rev. Samuel F. Dike became pastor, and continued so for fifty years, a man of deep scholarship, and widely known and widely influential, especially in connection with educational institutions of the State. In I 836 a society of the New Church was organized in Portland, and in 1878 a society in Fryeburg.

1 See account of the Weeks trial, in New Jerusalem Messenger of May 21, I884. 
The experience in Fryeburg was in some respects a repetition of the experience of the Rev. Holland Weeks in Abington. "On the $22 \mathrm{~d}$ of April, 1877," to quote the records of the Fryeburg Society, "Rev. Baman N. Stone, who for three years had been the settled pastor of the Congregational Church, made public acknowledgment that, for several years, he had been reading the works of Emanuel Swedenborg, and after much earnest study had now come to a full acceptance of their doctrines and claims. At the same time he read a letter resigning his pastorate. The Mutual Council, which was accordingly called, May 2d, unanimously advised the immediate dissolution of the pastoral relation. Among other things in the 'Result,' it was declared: 'We desire also to express, as representing the Congregational body, our utter and absolute dissent from the views of Swedenborg, and that we hold in common with all religious sects that it is a fatal error; and further that we believe that the Word of God is given to men in a form and in a language which can be understood by the use of ordinary human study and by the ordinary human mind without the teachings of Emanuel Swedenborg, but by the illumination of the Spirit promised to accompany the Word." ",

Mr. Stone withdrew, but was soon recalled to Fryeburg to become the pastor of a new society, which became a regular society of the New Church.

If these cases are taken as illustrating the attitude of New England Calvinism toward the New Church, it should be noted first of all that Mr. Weeks, and Mr. Stone, and Mr. Jenks, the pioneer of the New Church in Maine, who accepted the doctrines of the New Church, were Congregational ministers. But the council in each case represented the old-fashioned Calvinism which recognized the New Church as absolutely opposed to its fundamental doctrine of the 
vicarious atonement and salvation by faith alone, and to other doctrines which made one with this.

In what relation, on the other hand, did the New Church find itself with the liberal thought active and growing in New England, represented by the Universalists and Unitarians? I have said that the New Church found hardly more in common with the liberals than with the orthodox, which made their position extremely lonely - a mere handful of people holding to a great idea. The New Church and the liberals were at one in opposing the tri-personal idea of God and the vicarious atonement, but they looked in quite different, if not opposite, directions for the religion which should take the place of Calvinism. The difference was essentially this: the liberals felt a new light shining, a new air blowing, and they sought for new and rational interpretations of Christian faith and experience. With them it was to be an evolution. They knew not whither they were going, but they trusted to the power of human reason to lead them to safe harbors. The New Church believed that all real advance in spiritual life draws its vitality from revelation, and that the province of reason is to receive revelation understandingly, to confirm it and apply it. It believed that God had revealed in his Word, and in the opening of his Word through Swedenborg, the ideal toward which men should be living; toward which all his providence is tending; which will be realized as men coöperate with him. This opening of the Word they believed to be the promised second coming of the Lord; and the church to grow from this revealing they believed to be the New Jerusalem promised in the closing pages of the Scripture.

Liberal thought was not attracted by these claims; its trend was away from acknowledgment of the sole divinity of the Lord Jesus Christ and the acknowledgment of the 
supreme holiness of the Word, which were vital doctrines with the New Church. There was, too, a definiteness and positiveness, a tone of finality, about the New-Church teachings which was not pleasing. To use the figure of a dearly loved leader in the religious life of New England, Phillips Brooks, he preferred the breaking light of dawn to the full blaze of day. There is a truth here, and a lesson for the New Church to learn; but it is an error to suppose that the acceptance of a definite ideal and of clear-cut doctrines kills imagination and robs life of its charm and inspiration. It is far otherwise if the ideal is a divine ideal; then each truth learned invites to a thousand more; the wonder and the mystery grow. It is so in the study and practice of a natural science; it is no less so in learning and living the truth of heavenly life.

Perhaps the relation of liberal New England thought to the New Church is best seen in Ralph Waldo Emerson and the group of theologians, preachers, and literary people in and around Boston of whom he was the central figure, a group in which we may include Theodore Parker, James Freeman Clarke, Edward Everett Hale, and other distinguished men and women. These liberal minds were in touch with the group of Harvard students already mentioned who became devout members of the New Church. There was a close and lasting friendship between Emerson and Sampson Reed. Swedenborg in their time was a frequent topic of conversation in social and literary circles; lectures were given to acquaint the public with him; magazine articles and books appeared, to interpret, to expound, and to refute his views. There are many and extended references to Swedenborg in the essays and letters of these leaders of liberal thought showing the admiration and the hesitation felt toward Swedenborg and his teachings. The hesitation and the disagreement on vital points is implied in 
the fact that these men did not identify themselves with the New Church. I may be pardoned if I quote very briefly a few of their more favorable expressions. This from Theodore Parker, in a letter to Albert Sanford, in I853:

Swedenborg has had the fate to be worshipped as a half-god, on the one side; and on the other to be despised and laughed at. It seems to me that he was a man of genius, of wide learning, of deep and genuine piety.... The Swedenborgians have a calm and religious beauty in their lives which is much to be admired. ${ }^{1}$

It is hard to quote briefly from James Freeman Clarke. In his essay on "The Use of Time" he names Swedenborg with Voltaire, Wesley, and Franklin, and says:

Perhaps no four men of the century exercised a greater influence on the age than these. Swedenborg's thought has been slowly filtering into philosophy and theology, spiritualizing both.... His thought, so subtle and so deep, is gradually conquering the materialism of philosophy and theology, and so bringing down what he called the New Jerusalem. ${ }^{2}$

Edward Everett Hale in a lecture said:

Swedenborgianism has done the liberating work of the last century. ... The wave which Swedenborg started lasts to this day. ... The statements of Swedenborg's religious works have revolutionized theology. ${ }^{3}$

Emerson's essay on Swedenborg, in his Representative Men, written partly in high commendation and partly in disparagement is perhaps too well known to be quoted; it also needs to be read entire to be fairly estimated. Emerson valued highly the little book Observations on the Growth of the Mind, by his friend Sampson Reed. He sent a copy of

1 Life and Correspondence of Theodore Parker, by John Weiss, New York, I864, vol. I, p. 356 .

2 Self-Culture, by James Freeman Clarke, Boston, I882, pp. 76-82.

${ }^{3}$ Life and Mission of Emanuel Swedenborg, by Benjamin Worcester, Boston, I883, p. 4I6, and letter from Mr. Hale to the Rev. Clarence Lathbury in regard to the same, May 2I, I909. 
the book to Carlyle, and later in response to Carlyle's curiosity respecting the author and his church, he wrote with mingled praise and ridicule of the Swedenborgians, and concludes: "They are to me, however, deeply interesting as a sect which I think must contribute more than all other sects to the new faith which must rise out of all." 1

Such expressions may help us to complete our picture of the little band of New Churchmen in New England, between Calvinism on the one hand and liberalism on the other. It remains to speak briefly of the work done by the NewChurch body, the use made of its opportunity. We remember at the same time that there have always been an indefinite but considerable number of the followers of Swedenborg who have remained in their former church relations and have not favored separate organization. Among these have been some of the deepest students and ablest expounders of the doctrines, notably the Rev. John Clowes, rector of St. John's Church, Manchester, England. The work of the organized New Church is all that can be definitely reported. Even this is made more difficult by the fact that the constituency is greatly scattered, a few in almost every town, nowhere many. In New England the organization counts today but twenty-two societies with a membership of one thousand eight hundred and fifty.

This little body have sought to extend the influence of the truth which is so precious to them by public worship, by schools conducted under the care of the church, and by the publication and distribution of the works of Swedenborg and other New-Church books. A school for children of the New Church was opened in Boston in 1836 and continued a little more than seven years. In 1857 the New-Church Institute of Education was chartered, and in 1864 this corporation assumed charge of a New-Church school already established

I Correspondence of Carlyle and Emerson, letter of November, I834. 
(in I860) in Waltham. The Waltham School has been attended by one thousand three hundred and twenty-seven pupils. The New-Church Theological School, founded by the General Convention of the New Jerusalem, - one of two New-Church Theological Schools in America, and one of three in the world, - has been located in Massachusetts, at first in Waltham, then in Boston, and, since 1889, in Cambridge. One hundred and thirty-six students have attended the Theological School. At present, ten are in attendance, from our own and several foreign countries, and about one hundred persons are pursuing some study with the school by correspondence.

The strongest centres in this country for the printing and distributing of New-Church literature have been in New York and Philadelphia. From these two centres, aside from sales, approximately seven hundred thousand volumes of Swedenborg have been given, either free or on payment of postage, to libraries and to ministers, and countless smaller publications have been distributed. New England has also done work in printing and distributing. The New Jerusalem Magazine was established in Boston in I827, and, with two interruptions, has continued to the present time, under the names of New Jerusalem Magazine, New-Church Magazine, and New-Church Review. The Review is now published by the Massachusetts New-Church Union, which maintains a bookstore at $\mathrm{I} 34$ Bowdoin Street. For two different periods a children's New-Church magazine has also been published. The publication of Swedenborg in Boston was begun in I 794, the year of Mr. Hill's first visit, and by various agencies probably one hundred thousand volumes of Swedenborg in substantial form and two hundred thousand in cheap paper editions have been issued from Boston. The fifty members of the New Church in Connecticut have also carried on an extensive distribution. 
What has been the result of these efforts to extend a knowledge of the New Church, and to awaken an interest in its doctrines? The Lord alone knows. The opinions quoted above from James Freeman Clarke and Edward Everett Hale, that Swedenborg's thought has been spiritualizing both philosophy and religion; that Swedenborgianism has done the liberating work of the last century, and that the statements of Swedenborg's religious works have revolutionized theology, if they refer to effects consciously derived from Swedenborg, are doubtless exaggerations. If they include the unconscious influence of these writings, they are probably understatements of the truth. The little organization of the New Church makes no claim to being the great New Church of God; that Church is something far more grand, far more universal; it includes the great multitude that no man can number; but we believe, as already stated, that the opening of the Scriptures, by illumination from the Lord, through the writings of Emanuel Swedenborg, with the fuller experience of divine help thus made possible, is the promised second coming of the Lord; and that the holding and teaching and living of the doctrines so revealed, by those who receive them and recognize their source, be they many or few, is essential to the continuance of that light, and to its increase unto the perfect day.

"It is certain," wrote Swedenborg, a hundred and fifty years ago, "that a new church, which is the New Jerusalem, will exist." Why? On what did he base this certainty? Not upon evidence of such a church in his own day, for there were but a handful of men who cared for the new doctrines from the Holy Word which he knew must form the foundations of that church; not upon the eager reception of the books containing these doctrines, for they lay unopened in the libraries to which they had been given. The confidence in a new church was not based on any outward evidence, but 
on the fact that this church is foretold in God's Word. "It is certain that a new church which is the New Jerusalem, will exist," he wrote, "because it is foretold in the Apocalypse." 1 To the New Church, the vision of the Holy City in the closing pages of the Scripture, into which are gathered the promises of the Old Testament and the Gospels, is the Lord's revealing of the Christian life which shall be realized in its time. It is not a vision to be realized only in heaven; the Holy City was seen descending out of heaven; "the tabernacle of God is with men"; "the kingdoms of this world are become the kingdoms of our Lord, and of his Christ; and he shall reign forever and ever." To the New Church the essential principles of that blessed Christian life stand out clear and sure: the acknowledgment of the Lord; the acknowledgment of the holiness of the Word; and the life of obedience to the Ten Commandments. To the New Church this is not a vision to be enjoyed for an hour, and then to be dismissed from the mind; it is not a dream, but a rational ideal of Christian life for the individual and for society. It is a Divine ideal surely to be realized upon earth, " for the mouth of the Lord hath spoken it"; it is a Divine promise, to be kept ever in mind and heart; to be our guide, our strength, our joy, in all our going out and coming in, as we work and pray for its fulfillment.

1 Apocalypse Revealed, No. 547; also letter to Dr. Beyer, Documents, Vol. II, p. 383 . 

INDEX 



\section{INDEX}

Abington, Mass., 337.

Acton, Lord, 3.

Adams, Hannah, I04, 329.

Adams, John, 53, 232, 236, 325 .

Albany Convention of $1852, \mathrm{I} 8,65$, 66.

Ames, Charles G., 93.

Andover, Mass., 32.

Andover Theological Seminary, 50, $59,63,102$, 104, I3I-I33, 27 I.

Andros, Sir Edmund, 26, 27, 215, 216.

Antinomian controversy. See Hutchinson, Anne.

Anti-slavery movement, 245, 246, 286, 287 .

Arianism, 5I, 52, I 2 I.

Arlington, Mass., I6I.

Arminianism, 50-52, 78, 98, I4I, I 72-I 74, 308 .

Asbury, Francis, 256, 260.

Austin, Ann, I80.

Backus, Isaac, I 56, I57, I59, I60, I62, I65, I66, I 75 .

Bacon, Leonard, 72.

Ballou, Adin, 3 I 4.

Ballou, Hosea, 298, 302-304, 308, 309, 3 I3, 3I4, 3I6, 3I9.

Bangor Theological Seminary, 63 .

Baptists, I6, I 7, 25, 49, 78, 79, 8688, г 37-г 76, 299.

Barnstable, Mass., I45.

Barrowe, Henry, 6, 7 .

Bartol, Cyrus, 263.

Bass, Edward, 239, 240.

Bates College, 8o, I74.

Bath, Maine, 339.

Bay Psalm Book, 23, 24.

Beecher, Henry Ward, 72, 73, 79, 302,305 .
Belknap, Jeremy, 238, 298.

Bellingham, Mass., 175 .

Bellows, Henry W., 264.

Berkeley, George, 222, 223.

Berkeley Divinity School, 246.

Bishops, American, 53, 23 I-236.

Blackstone, William, 206, 207.

Books, read in New England, 38-4I.

Boston, II, I 2, I 7, 29, 30, 52, 85, I 5I, I 54, 206, 2I3, 2I4-2I6, $225,254,255,258,284,328$, $329,344,345$.

Brattle St. Church, 28, 30, I07.

Christ Church, 34, 221, 227, 229, 254.

Church of the Advent, 245.

First Baptist Church, I7, I 5I, I 53 .

First Church, 5 I, 99, I 54, I 55.

First Methodist Church, $25^{8}$.

Morgan Memorial 28I-284.

Old South Church, 24, 27, 59, I 55,2 I 5 .

Second Baptist Church, I 55.

Society of the New Jerusalem, 336, 337.

Trinity Church, 22I, 230, 24 I.

See also King's Chapel.

Boston Synod, 20.

Boston University, 266, 270-272.

Bowne, Borden P., 267-269.

Bradford, William, 8, 24.

Brewster, William, 4, 5 .

Bridgewater, Mass., 337 .

Bristol, R. I., 2 I9, 229, 240, 24 I.

Brockton, Mass., 337.

Brookline, Mass., 337 .

Brooks, Phillips, I3I, 247, 302, 305, 342.

Brown, Samuel and John, 2 Io.

Brown University, I63-I68. 
Browne, Robert, 5, 6, I37, 139 .

Burial Hill Declaration, 66, 67 .

Bushnell, Horace, 72, I3I, 302, 305.

Butler, William, 277.

\section{Calvinism:}

Consistent Calvinists, roo, ror.

Hopkinsians, 48-50, 59, 90, ror, I02, I30.

Moderate Calvinists, 99, IOI, IO2, II 2 .

New Divinity men, 5o.

New England Theology, 43, 48 .

Old Calvinists, 50, 59, 90.

Cambridge, England, University of, I3.

Cambridge (Newtowne), Mass., I2, I6, I 7,62, I 50, $227,230,337,345$.

Cambridge synod and platform, 16 , I8-20, 34, 35, 85 .

Camp meetings, 285,286 .

Canterbury, N. H., 78 .

Channing, William Ellery, 6o, I 16 , I 7 , I 20, I 26, 3 I 6 .

Charlestown, Mass., II, I 2, I 5 I, I 53, 206.

Chauncy, Charles, 5I, I50, 226, 298, 299.

Chelsea, Mass., 206.

Christian Connexion, 82.

Christians, $77,80-84,87,88,90$, $93,97,98$.

Church and state, $7, \mathrm{I}_{2}-\mathrm{I} 5,20,25$, $36,37,47,54,6$ I , 62, 84, 106-109, I37-I39, I 57-I63, 310-312.

Claremont, N. H., 228, 229, 3 I I.

Clarke, James Freeman, 305, 342, 343.

Cleaveland, John, 298.

Cobbett, Thomas, I47.

Colby College, 167 .

Coleridge, Samuel Taylor, I3I.

Colman, Benjamin, 34, 46, 225.

Columbian University, I70.

Conant, Roger, 209, 2 Iо.

Concord, Mass., 280.

Concord, N. H., 270.

Congregational Creed of 1883,69 .
Congregational national councils, 68.

Congregationalism, $3,7^{-9}, \mathrm{x} 2$, 19 , $35-37,47,58,66,67$, г 37, г 38,3 г 2.

Congregationalists, $3-73, \mathrm{I} 37, \mathrm{I} 40$, I54, I56, I6 I, I63, I66, 210, 219, 228, 232, 340.

Connecticut, I6, 21, 34, 36, 46, 47, $54,64,65,230,299,306,345$.

Contoocook, N. H., 337.

Cotton, John, I3, I4, 4I, I43, I45, $2 \mathrm{I} 2$.

Covenant, 8.

Craigie, Andrew, 326.

Creighton, Mandell, 3 .

Customs:

New England Puritans, 22-26, 28, 29.

Quakers, I87-I94.

Cutler, Timothy, 33, 34, 219-221, 225.

Dartmouth College, 47 .

Deaconess Association, 279, 280.

Dedham case, 6r, ro6, ro8-i 2.

Deerfield, Mass., 23.

Democracy, 8, 14, 36, 56 .

Dike, Samuel F., 339.

Disciples (Campbellites), 82 .

Dorchester, Mass., I 2, 2 I.

Dover, N. H., 2 I8.

Duché, Jacob, 325.

Dunster, Henry, I 7, I49, I 50.

Dyer, Mary, I84, 245.

Eastburn, Manton, 244.

Eastham, Mass., 285.

Edwards, Jonathan, 42-45, I00, IOI, I 22, I 29, I30, 223, 26 I.

Eliot, John, I7, I8.

Elmwood, Mass., 337.

Emerson, Ralph Waldo, 60, 91, 92, I 27-I 29, I 3 I, 342, 343 .

Episcopal Theological School, Cambridge, 246, $27 \mathrm{I}$.

Episcopalians, 9, 26, 27, 33, 34, 47, $53,55,58,86$, I 37, I 58 , I 59, I66, $205^{-247,} 25^{2}$. 
Fairfield, Conn., 230.

Fall River, Mass., 337.

Fisher, Mary, I80.

Fisk, Wilbur, 260, 264-266, 286.

Fiske, John, I42, 208.

Foreign Missions, 70, II5, I69-172, $277,278$.

Fox, George, I79, I84.

Free Will Baptists, 77-80, 81, 82$84,87,88,90,93,95$, I 74 .

Freeman, James, 58, 230, 237-239, 258.

Fryeburg, Maine, 339, 340.

Gainsborough church, I39, I40.

Gardiner, Maine, 228, 339.

Garrettson, Freeborn, 254.

Gatchell, Joseph, 298.

Glenn, James, 325, 328 .

Gloucester, Mass., 299, 300, 3 ro, 3 I 7 .

Gorges, Sir Ferdinando, 205, 206, 2 IO.

Gorton, Samuel, 298.

Great Awakening, 42, 45-47, 78, 9I, 92, I 55, I 56, 223, 224, 226, 24 I.

Great Barrington, Mass., 24I.

Greenwood, John, 6, 7.

Griswold, Alexander Viets, 240, 241.

Hale, Edward Everett, 342, 343 .

Half-way covenant, 29, 30, 43, 85, I $54-$ - 56 .

Hampton, N. H., 218.

Harrison, Frederic, 103.

Hartford, Conn., I 2, 21 , 254.

Hartford Theological Seminary, 63.

Harvard College, I 7, г8, 23, 28, 29, $34,45,59,63,97,98$, 1 55 , II 2 , I 32, I 33, I49, I 50, I 54, I63-г66, $218,225,242,271,326-328$.

Haverhill, Mass., I56, I 75 .

Hedge, Frederick H., I 25.

Hibbard, Billy, 88-90.

Higginson, Francis, IO, I I, I43, 2 I 2.

Higginson, John, II, 22.

Hill, William, 325, 326 .

Hollis, Thomas, 154 .
Hollis professorship, 59, 102-105.

Holmes, Obadiah, I48-ז 50.

Honeyman, James, 2 I8, 223.

Hopewell, N. J., Academy, I65, r66.

Hopkins, Mark, 72.

Hopkinsianism. See Calvinism.

Huntington, Joseph, 299.

Hutchinson, Anne, I 5, 16, I 24, I85.

Indians, I7, 18, 43, 47, г70, г7 7 .

Ipswich, Mass., 36, I47.

Jacob, Henry, I45.

Jacob-Lathrop-Jessey Church, London, I40, I4I, I45, I47.

Jenks, William, 339,340 .

Johnson, Samuel, 220-223, 231 .

Jones, Abner, 77, 78, 80-82, 97.

Judson, Adoniram, r69-г 7 r.

Kansas City formula, 69, 70.

Keith, George, 217.

King's Chapel, 27, 34, 58, 99, I I3, $215,218,222,229,237-239,253$, 330.

Kingston, R. I. (Narragansett church), 2I9, 229, $24 \mathrm{I}$.

Kirkland, John T., $25^{8}$.

Kittery, Maine, I 55 .

Lancaster, Mass., 337.

Lathrop, John, I40, I4I, I45, 147 .

Lebanon, Conn., 47.

Lecky, W. E. H., 56, 72.

Lee, Jesse, 52, 254-256, 260.

Liberal Christians, 50-52, 57-60, 97,98, I01-106, 108, І13, ч16I 18.

Litchfield, Conn., 254 .

London, 5, I39-I4I, I44, I45, I47.

London-Amsterdam Church, 7 .

Londonderry, N. H., 55 .

Lonsdale, R. I., 207.

Lowell, Mass., 285 .

Lyford, John, 208-2 Io.

Lyndon, Vermont, 80.

Lynn, Mass., I47, 148, 218, 255. 
Maine, 167, 205, 210, 243, 306.

Manchester, N. H., 337 .

Mansfield, Mass., 337.

Marblehead, Mass., 22I, 263, 298.

Marks, David, 93-95.

Martha's Vineyard, $18,285$.

Massachusetts, I 2-20, 26-32, 35, 36, $54,55,59,61,62,84-88,98,99$, 106-I 1 2, 142-163, 180, 206-219, 221, 229, 230, 243-245.

Masson, David G., I39.

Mather, Cotton, 3I-33, 39, I 54 .

Mather, Increase, $7,27,28,30-32$, 35, I 54, 21 8, 254 .

Mattapan, Mass., 84.

Maverick, Samuel, 206-208.

Mayhew, Jonathan, 51, 298.

Meeting-houses:

Methodist, 258, 259.

Puritan, 22.

Mendon, Mass., 315.

Mennonites, I4I.

Methodists, 52, 53, 88, 25I-294.

Middleborough, Mass., I 56, I 57 , I 75 .

Morell, Robert, 206, 207.

Morse, Jedidiah, I04, I05, 258.

Morton, Thomas, of Merrymount, I 4, 207, 208.

Murray, John, 258, 299-302, 304, 306, 308, 310, 313, 3I 7, 319.

Mysticism, I85-187.

Nantucket, 244.

Narragansett church, Kingston, R.I., 2I9, 229, 24 I.

Natick, Mass., I8.

New-Church Theological School, 345 .

New Durham, N. H., 78, 774.

New England Primer, 39-4I.

New Hampshire, 173, 213, 243, 299, 306, 3II, 312.

New Haven, Conn., 21, 222, 255.

New Lights (Separatists), 47, 48, 78, I 56, I 57, I 68 .

New London, Conn., 230.

Newbury, Mass., I6, 221.
Newburyport, Mass., 23, 239, 241.

Newport, R. I., 49, I45, I47, I80, 218, 229, 241, 306, 307 .

Newton Theological Institution, 167 , I68, I 7 I.

Newtonville, Mass., 337.

Northampton, Mass., 42, 43 .

Norton, Andrews, 60.

Norwalk, Conn., 255.

Norwich, Conn., 230.

Norwich, England, 5, 6 .

Oldham, John, 209, 2 Io.

Oxford Movement, 243-245.

Park, Edwards A., 66, 67.

Parker, Samuel, 240.

Parker, Theodore, 60, I I 2, I I 7, I 26, I 27, 342, 343 .

Pearson, Eliphalet, r03-ro5.

Pennyrial hymns, 92, 93.

Peters, Samuel, 228.

Philadelphia Convention and Articles of Faith (Universalist), 3 r3.

Plan of Union (Congregationalist and Presbyterian), 37, 64-66.

Plymouth Colony, and Plymouth, Mass., Io, I 2, 24, 25, 27, 59, I39, I 48, I 50, 208.

Portland, Maine, 2ro, 228, 339.

Portsmouth, N. H., 210, 228, 24 I.

Presbyterianism, I6, 21, 28, 35-37, $55,64,65$.

Propagation of the Gospel in Foreign Parts, Society for the, 18,217 , $219,227,232$.

Propagation of the Gospel in New England, Society for the, 18, 217 .

Providence, R. I., and Providence Plantations, I6, I45, I47, I48, 163, 172, 207, 219, 229, 241, 254, 306, 337 .

Provoost, Samuel, 234-238, 243.

Quakers, I5, 86, 87, I 24, I 58, I 59, I66, 179-201, 217, 218.

Quincy, Mass., 207. 
Randall, Benjamin, $77,78,80,82$, I73, I74.

Randolph, Edward, 26, 27, 214, 2 I6.

Ranke, L. von, I4I.

Ratcliffe, Robert, 27, 213, 216-218.

Redding, Conn., 230.

Reed, James, 336 .

Reed, Sampson, 327, 343 .

Relly, James, 299, 300-302, 3 I3.

Revolution, American, 52, 160, 22823 I, 242.

Rhode Island, 22, I97, 200, 2 I 8, 222 , 229, 243, 298.

Rich, Caleb, 3 I3.

Robinson, John, 6.

Robinson, William, 2 I6.

Roman Catholics, 55, I 58, 288.

Roxbury, Mass., I 7, 21, 337 .

Rush, Benjamin, 3I3.

Salem, Mass., II, 32, 84, I80, 209, 2I0, 2I8, 3I 2 .

Sandwich, Mass., I80.

Sargent, Abel, 3 I3.

Saybrook, Conn., 32 .

Saybrook synod and platform, 21, 34-37, 220.

Scituate, Mass., 145, I 50.

Scott, Job, 197.

Scrooby, 4, IO, I39, I40.

Seabury, Samuel, 233-237, 240.

Seekonk (Rehoboth), Mass., I47, I48.

Separatists in Connecticut. See New Lights.

Sewall, Samuel, 18, 24, 33, 214, 2 I 5 .

Simpson, Matthew, 293.

Smith, Elias, 8I, 82.

Springfield, Mass., 2I, 337 .

Standing Order, 20, 77, 98. See Church and state.

Statistics:

Baptists, I64, I 76 .

Christians, 82.

Episcopalians, 247.

Free Will Baptists, I74.

Methodists, 288.
New England churches in 1700 and 1800,55 .

Quakers, I8r.

Swedenborgians, 337, 344, 345 .

Universalists, 306 .

Sterling, Mass., 285 .

Stevens, Abel, 260.

Stiles, Ezra, 25, 36, 49, 53, 221, 255 .

Stockbridge, Mass., 43.

Stone, Baman N., 339, 340.

Stratford, Conn., 221.

Stuart, Moses, 6o, 72.

Sturbridge, Mass., 159.

Swedenborg, Emanuel, 326, 327, $330-336,340-347$.

Swedenborgians, 325-347.

Taylor, Father, 262-264.

Taylor, Nathaniel W., 65 .

Theocracy. See Church and state.

Trinity College, Hartford, 246.

Turner, William, I 53 , I 54 .

Unitarians, 52, 57-6r, 71, 97-133, $237-239,274,275,301,304,305$, 308,3 I 2, 3I 7, 318, 320, 328, 34I.

Universalists, 52 , 100, 297-321, 328, $34 \mathrm{I}$.

Vane, Sir Harry, I44, 297.

Vermont, 243, 246, 306.

Waltham, Mass., 337, 345 .

Ware, Henry, 60, I02, I04, 105.

Ware, Henry, Jr., I 26.

Warren Association of Baptist Churches, I 59, I 75 .

Warren, R. I., I 75 .

Warren, William Fairfield, 267.

Watertown, Mass., $2 \mathrm{I}$.

Weeks, Holland, 337-339.

Wesley, Charles, 253.

Wesley, John, 42, 52, 54, 223, 25I254, 26r, 262, 286, 290, 29 I.

Wesleyan University, 265, 266.

Westminster Confession, I9, 20, 28, 33.

Wethersfield, Conn., 2 I. 
White, William, 234, 236.

Whitefield, George, 34, 45-47, 78, 223-226, 24I, 253.

Whittemore, Thomas, 314.

Wigglesworth, Michael, 38 .

Williams, Roger, $\mathrm{r} 4, \mathrm{r} 6, \mathrm{r}_{42}-\mathrm{r} 45$, r47, 2r6, 245.

Winchester, Elhanan, 313.

Winchester Profession of Belief (Universalist), 307-3ro.

Windsor, Conn., 2r, 42.

Winstanley, Gerard, r98.

Winthrop, John, I2, I4, 20, 26, I43, I 44,2 r 2.

Wise, John, 36 .

Witchcraft, 3r, 32 .

Wolsey, Theodore D., 33, 220.

Worcester, Mass., 254, 284.

Worcester, Thomas, 326, 327, 329, 336.

Yale College, 23, 32-34, 45, 48, 63, ro5, r63, r66, 2r9, 220, 222, 242. Yarmouthport, Mass., 337. 

PRINTED AT

THE HARVARD UNIVERSITY PRESS

CAMBRIDGE, MASS., U.S.A. 





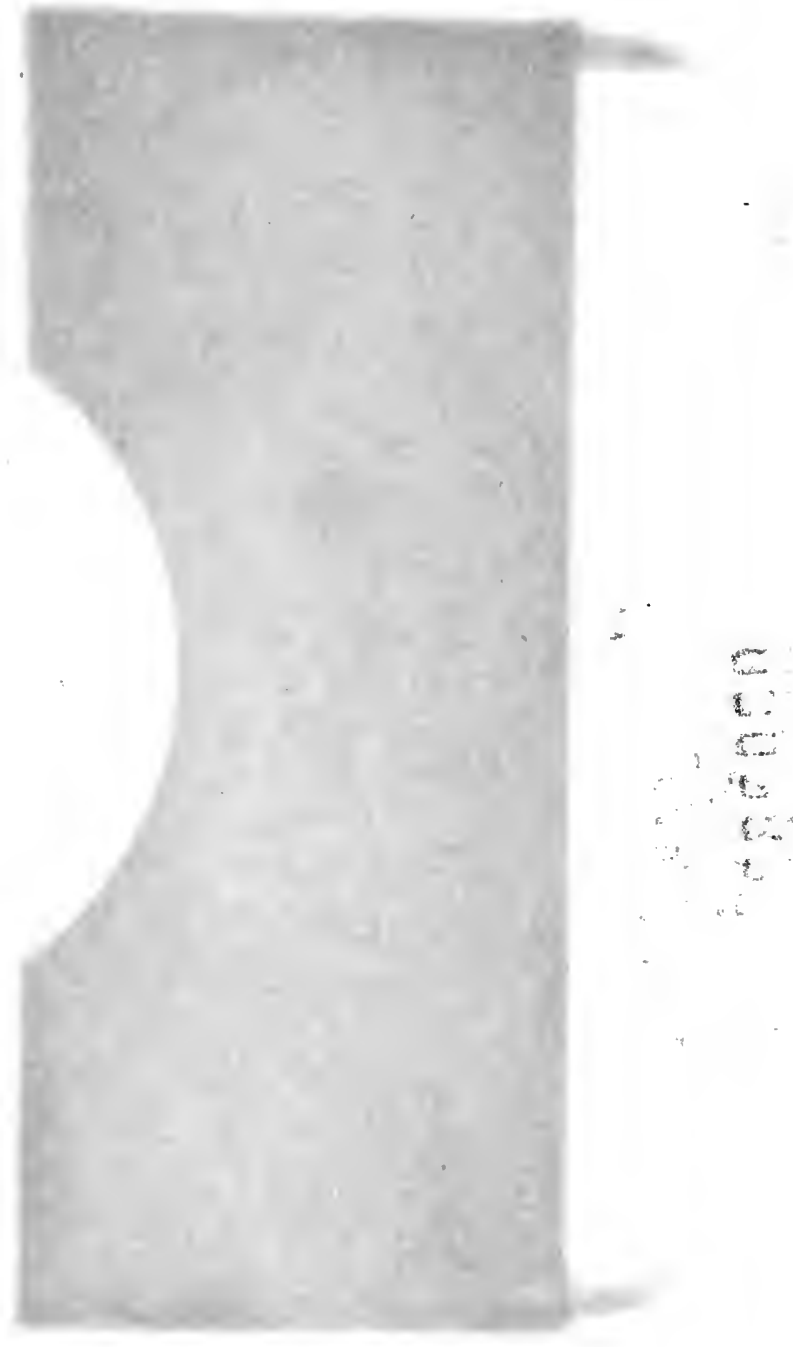




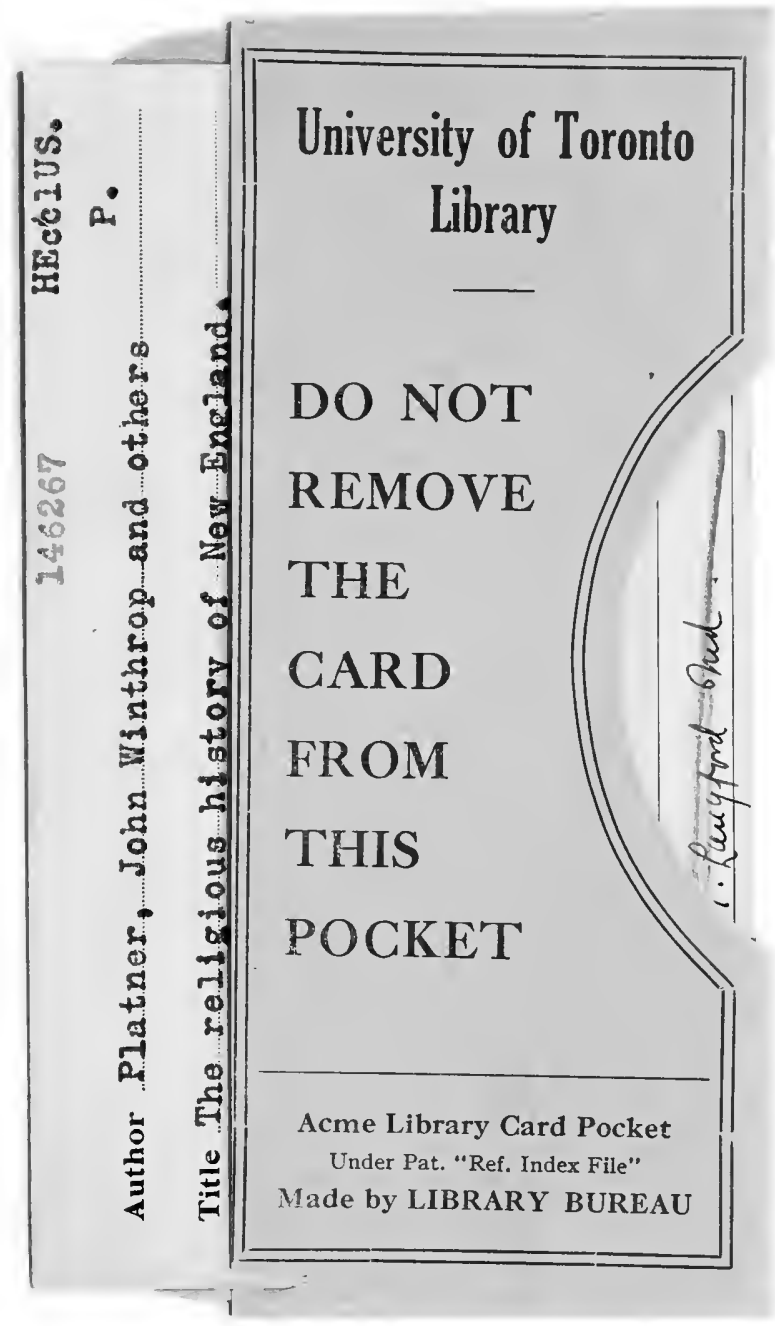


